

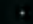



$A-4$ 

Q) El. Elas. WV. Yxiinmond

684

with compliments of

Msw6 4

Ctto USidmann

Birds

A PRELIMINARY CATALOG

OF THE

\section{BIRDS OF MISSOURI}

B Y

OTTO WIDMANN

ST. LOUIS, MO.

1907 



\section{A PRELIMINARY CATALOG OF THE BIRDS OF MISSOURI.*}

\section{OtTo WidmanN.}

\section{INTRODUCTION.}

The need of a list of the birds of Missouri has become more and more apparent as the popularization of Nature Study has made progress during the last few years. Nearly all the northern states have published for many years lists and revised lists, but this is the first attempt in our state. It is based chiefly on personal observations made during the last thirty year's. Other sources of information of which I was able to avail myself are comparatively few and very little has ever been published. To those gentlemen who were kind enough to favor me with their notes I would here express my thanks. They are: Mr. Vernon Bailey of Washington, D. C., who visited Stone Co. in 1892 for a short time; Mr. Roger N. Balclwin of St. Louis; Mr. James Newton Baskett of Mexico, Mo., the author of the Story of the Birds; Mr. John A. Bryant of Kansas City; Mr. B. F. Bush of Courtney, Mo.; Mr. Edmonde Sanuel Currier of Keokuk, Ia., who kept very good records of the birds of his vicinity including parts of Clark Co., Mo., for more than twelve years prior to his removal to Oregon in 1903; Dr. Aug. F. Eimbeck and his brother, Mr. Charles L. Eimbeck, of New Haven, Mo., the owners of fine collections of mounted bircls made in Warren and Franklin Co. during the last forty years; Mr. Ben True Gault of Glen Ellyn, Ill., who has twice collected in parts of southern Missouri, mainly in Dunklin and Reynolds Co.; Mr. Julius Hurter, Sr., of St. Louis, whose collection of mounted birds of the neighborhood of St. Louis is now in Washington University; Mr. John D. Kastendieck of Billings, Christian Co., the owner of a large and fine collection of mounted birds taken in his vicinity during the last forty years; Mr. Adolf Lange of Leavenworth, Kan., whose collection of birds contains specimens taken on the Missouri side; Mr.

* Presented to The Academy of Science of St. Louis, May 21, 1906. 
John S. Marley of Kansas City, Mo.; Dr. Walter Mills of Webster Groves, Mo.; Mr. H. Nehrling, the author of "Die Nord-Amerikanische Vogelwelt" and "Our Birds of Song and Beauty," who lived at Freistatt near Pierce City, Lawrence Co., from October 1882 to April 1887; Mr. Edgar M. Parker of Montgomery City, Mo.; Mr. Otho C. Poling of Quincy, Ill.; Mr. Wm. E. Praeger, who, when living at Keokuk, Ia., often visited Missouri soil on his ornithological excursions; Mr. F. C. Pellett of Salem, Mo.; Mr. C. W. Prier of Appleton City, Mo.; Dr. G. C. Rinker of Unionville; Mr. Walter Giles Savage of Monteer, Shannon Co., formerly of Jasper, Jasper Co.; Mr. Frank Sehwarz of St. Louis: Mr. Plilo W. Smith, Jr. of St. Louis, an ardent collector of eggs for many years in different parts of the state, bringing together one of the most complete collections of North American birds' eggs in the United States; Mr. A. F. Smithson of Warrensburg, Mo.; Mr. B. M. Stigall of Kansas City; Mr. Chas. W. Tindall of Independence, Mo.; Mr. Sidney S. Wilson of St. Joseph, Mo.; Mr. Julius T. Volkman of Webster Groves, Mio.; Mr. E. Seymour Woodruff, who visitd Shannon Co. from Mareh 10 to May 16 and Grandin, Cartel Co., from May 16 to June 7,1907 , and very kindly submitted all his notes, containing new and valuable records, for use in this list; Mr. Chas. K. Worthen of Warsaw, Ill., who sent me interesting notes on birds taken on the Mississippi River or so near the state line that they must be regarded as worthy of a place in our list. I am also indebted to the gentlemen of the Bureau of Biological Survey of the United States Department of Agriculture, for the loan of the schedules containing the reports on bird migration in Missouri from 1884 to 1905 . They comprise the work of thirty-six observers seattered through nearly as many counties and varying from notes on a few birds in a single season to full reports on a number of species and a long series of years, chiefiy for spring, but some for spring and fall migration.

\section{BIBLIOGRAPHY.}

The first local list ever made in the state is that of Dr. P. R. Hoy, published in his Journal of an Exploration of Western Missouri in 1854 in the nineteenth Annual Report of the Smitisonian Institution for 1864. He enumerates 156 species.

Occasional mention of birds of the lower Missoun' River is found among the observations of Max Prinz zu Wied in his "Reise in das Innere Nord-America in den Jahren 1832 bis 1834" 
and in his "Verzeichniss der Vögel welche auf einer Reise in NordAmerica beobachted wurden" in the "Journal fuer Ornithologie," for 1858; also in Long's Expedition to the Rocky Mountains in 1819 and '20, published from notes of Thomas Say in 1823; and in F. V. Hayden's Report on the Geology and Natural History of the Upper Missouri River based on explorations in 1855, '56 and '57, published in the Transactions of the American Philosophical Society, vol. 12, 1863.

A few notes on the birds of Missouri are found in J. H. Townsend's Narrative of a Journey across the Rocky Mountains in 1839 (vol. 21 of Early Western Travels), and a larger number in Audubon's Missouri River Journals, 1843, in "Audubon and his Journals," by Maria R. Audubon, 1897. Edward Harris, who accompanied Aludubon on his journey to the upper Missouri in 1813 published a nominal "List of Birds and Mammalia found in the Missouri River from Fort Leavenworth to Fort Union" in the Fifth Annual Report of the Smithsonian Institution, 1850 (1851).

In his "Notes on an Ornithological Recomoissance," Dr. J. A. Allen writes in the Bull. Mus. Comp. Zool., vol. 3: p. 6, July 1872: "Our collections at Leavenworth (in May 1871) were principally made in the heavy timber on the East Leavenworth (Mo.) side of the Missouri River opposite Fort Leavenworth. Most of the water-birds were obtained about a lagoon on the Missouri side." In Bull. Nuttall Ornith. Club, vol. 3, p. 148, 1878 , is a notice by Dr. J. A. Allen of the occurrence of three species of seaducks and a purple gallinule taken near St. Louis by Mr. Julins Entrer in 1875, '76 and '77. In vol. 4, 1879, page 139 117 , of the Nuttall Bulletin there is a list of 148 species observed by Mr. W. E. W. Scott at Warrensburg, Mo., during the spring migration, Harch 27 to June 15, 1874. In the Ornithologist and Oolosist of 1881, Mir. Ju1. Hurter of St. Louis enumerates 205 species of birds collected by him during fifteen years in the vicinity of St. Louis. Mr. Otho C. Poling of Quiney, Ill., in his "Notes on the Fringilliclae of western Illinois," in the Auk, vol. 7,1890 , speaks of observations made on Missouri soil.

Several yapers treating of Missouri birds have been published by the author of the present list during the last twenty years in the : ak, the Omithologist and Oologist, the Osprey, and Bird Lore. The Reports on Bird Nigration in the Mississippi alley by W. W. Cooke also contain a large number of notes and dates on Missouri birds, chie?ly from St. Louis. The report for the 
spring of 1882 is published in Forest and Stream during October and November of that year; that of the spring of 1883 is published by the American Field in Bull. no. 1 of the Ridgway Ornithological Club of Chicago, December 1883. The reports of 1884 and 1885 are contained in Bull. no. 2 of the Department of Agriculture, Division of Economic Ornithology, entitled: "Report on Bird Migration in the Mississippi Valley in the years 1884 and 1885," by W. W. Cooke, 1888, edited and revised by Dr. C. H. Merriam.

\section{EXPLANATIONS.}

The nomenclature is that of the American Ornithologists' Union check-list, latest (1895) edition and supplements. The numbers are also those of the check-list; the species and subspecies have not been serially numbered, because in a preliminary list it is too difficult to decide which shall and which shall not be numbered; a species doubtful to-day may have to be recognized to-morrow, and species which have occurred lately may soon be found exterminated as far as this state is concerned. Species and subspecies which are known to have bred in the state, or which occur under such circumstances that it is almost certain that they breed within the limits of the state, are marked with an asterisk. Synonyms, both scientific and English, used in the works of American ornithologists, principally those used by Wilson, Audubon, Nuttall, Baird, and Coues, are given to enable students to find their way through the many and great changes in nomenclature made since the first of these books was printed ninetyeight year's ago. No attempt is made to describe birds; manuals, handbooks, keys, and general works on North American ornithology are numerous. The catalog is confined to a detailed treatment of the geographic distribution of each species and subspecies in accordance with the latest sources of information. This is followed by a statement of its range in Missouri, manner of occurrence in regard to season and relative abundance, dates of arrival and departure, and such notes as may be helpful to the student in the search of rare species. Species are called residents when they are found within the limits of the state in every month of the year; they are sometimes called permanent residents when they remain in the same locality throughout the year, but of this kind we have but very few, while of many species some individuals remain through winter with us, though the majority go outh. Of a few species the numbers are larger in winter than 
in summer, because reinforced by winter visitants from the north. Winter visitants are those which are found only in the colder part of the year and return to the north sooner or later in spring; when they are of regular occurrence and long sojourn in the same locality every winter, they are also called winter residents. Summer residents are those which pass the warmer part of the year in our state, leave us in autumn and return in spring. A few species may properly be termed summer visitants, because they visit the state only for a short time after their breeding season in a more southern home is over. Transient visitants are all those speeies which breed farther north and winter farther south, passing through our state in migration and spending more or less time in the transit.

Residents and summer residents are breeders; transient visitants, summer visitants, winter residents and winter visitants are non-breeders in the state.

The terms used to indicate relative abundance may be defined thus: Common means of such regular occurrence in all suitable localities at the proper time that individuals ean be found without any effort. Fairly common, meaning moderately common, is used to indieate that the speeies, though of regular oceurrence in suitable localities, is so thinly seattered that it requires more or less search to find it. Rather rare means uncommon, infrequent, known to occur only in small numbers, requiring much search. Rare means oceurring at wide intervals. As the result . of persecution or adverse cireumstance formerly common speeies have been reduced to this state. Aceidental designates those which are entirely unexpected because extralimital.

The eatalog contains not only species and subspecies fully authenticated, but also a few of such highly probable occurrence that it seems only a question of time and opportunity to establish the proof of their presence. This is a slight deviation from the usual course of relegating everything not fully verified by captured specimens to an appended, generally overlooked, hypothetieal list. But sinee this eatalog is in an initial stage, far from completion, I hold it to be of the greatest importance to keep constantly before the eyes of the student what should be done in the way of filling the gaps. He should not only know what has already been accomplished, but also what he can do in the locality in which he works toward eompleting the list. When visiting a new locality it is a great help to know beforehand for 
what one should watch, particularly in order to make a discovery of value.

Apparently extirpated species are also retained in the list, because it is interesting to know what formerly occurred in the state, and because the possibility still exists that at least a few individuals remain or have returned from adjacent regions. Introduced species are also admitted as naturalized members of our avifauna.

The total number of species and subspecies contained in the catalog is 383, of which 162 are breeders. Species not actually taken within the limits of the state are distinguished by being put into brackets. Of this kind there are 30 , which subtracted from 383 leave as the present status (July 8, 1907) 353 actually observed species and subspecies for our state.

\section{FAUNAL AREAS.}

Our avifauna is mainly that of the eastern United States generally and differs little from that of the adjoining states on the east, north and south. The Eastern Province reaches from the Atlantic occan to the foothills of the Rocky Mountains, where the Middle Province begins, but many of the western forms of birds extend eastward into Kansas and still more so into western Nebraska, thus swelling the number of species and subspecies in the latter state to 415. Illinois, too, has a larger list of breeders as well as of winter visitants, because her fauna is enriched by water birds visiting Lake Michigan and by its great north and south extension, which enters the Alleghanian faunal area of the Transition zone in the north and reaches with its southern end slightly into the Austroriparian area.

Missouri belongs almost entirely to the Carolinian faunal area of the upper Austral life zone; only the low alluvial counties of the southeast can be considered a spur of the Austroriparian faunal area of the Lower Austral life zone. The circumstance that all our rivers of the southern slope of the Ozarks have wide, open and long valleys leading southward gives an opportunity fo. a northward advanee of southern forms of plants and animals; and our broad, open prairie region of the west and north offers no barrier to an eastward spreading of the western fauna and flora.

In comparing the avifauna of Missouri with that of the Atlantic States in the same latitude it should be remembered that. although the mean temperature differs but little, the climate of 
the former is somewhat more severe than that of the latter, the summers being hotter, the wintess colder. It is therefore not surprising to find slight differences in the summer and winier faunas of the two regions, while the migrations occur at nearly the same time, owing to the similarity in temperature of the spring and fall months.

\section{THE CLIMATE.}

The climate of Missouri, continental as it is in a high degree, is one of great variations. Generally speaking it may be said that it is characterized by hot summers and moderately cold winters, with exceptions of modeiately hot summers and very cold winters. Maximum temperatures of eighty degrees and over oceur during the summer on eighty to ninety days; ninety degrees and over on twenty to thirty days. In ordinary winters the temperature reaches to and below the freezing point on about eighty days and fallis below zero on trom ten to twenty days. There are on record a few exceptionally moderate winters like that of 1905-'06 when the zero mark was hardly reached, or reached only in the more northern counties. There is little difference in the amount and duration of the summer's heat in the different parts of the state, but there is a difference of five degrees in the average winter temperature between the northwest and the center, and from ten to fifteen degrees between that of the northwest and the southeast. All waves, cold and warm, appear first in the northwest and advance southeastward, requiring about twentyfour hours to reach the southeastern corner of the state. The most pronounced polar waves of midwinter are nearly as cold in one part of the state as in the other, but cold periods are generally of shorter duration in the southeast, moderating more rapidly under the more southern sun and the lower elevation. This is especially noticeable in the beginning and at the end of winter, but, due to its northwest-southeast course, the chilling effect of a departing high barometer may still be felt strongly in the southeast when the approaching low barometer has already entered the state $n$ the northwest with rapidly rising temperature. Such conditions are particularly striking in spring, when north-bound migrants are thereby enabled to depart, while no migration reaches us from the south, then still under the influence of the cold east and southeast winds of the departed high pressure. The first frosts occur late in October, in the southern part sometimes not before 
November, but exceptionally the last of September even in the southeast. The last frost oceurs in the south about the first, and $i_{n}$ the north about the fifteenth of April, exceptionally later as on April 20, 1904, when six inches of snow covered the ground at St. Louis with a temperature of $28^{\circ}$ to $30^{\circ}$ (max.). Hoarfrosts may kill tender vegetation as late as the middle of May in nearly all parts of the state.

The following dates may illustrate the remarkable dissimilarity in dates of opening spring: Peach-trees were in bloom in St. Louis in 1878 on March 15; in 1907 on March 25; in 1879 on April 15; in 1880 on April 1 and in 1881 on April 28. The same Magnolia which was in flower on March 12, 1878, did not bloom in 1881 before April 24, but in 1882 again as early as March 18, when spring opened on the first of March. Though spring opened in 1881 only on April 16 not a single tree was without its leaves at St. Louis on May 9; but in 1907 the leafing of trees began March 15 and was not completed June 1 . An exceptionally early opening of spring with us can, of course, have no influence on the starting of migrants from their remote winter homes in southern Mexico, Central and South America, as they cannot know what kind of weather we have in the United States, but a late spring may retard their progress after they have entered our country. Most of the bircls which winter beyond the limits of the United States do not reach Missouri hefore April, and their arrival is therefore not influenced by our weather prior to that time. They do not come carlier, be the spring ever so early and vegetation correspondingly advanced; but it is different with birds which winter within the United Stales, as nearly all species do which arrive in Missouri prior to April. Though the desire to return to their breeding ground is not dejendent on the weather, being the result of a physiological process which through inheritance is fixed to a certain time of the year independent of meterological conditions, a precocious rise in temperature with the consequent development of plant and animal life excrts some influence by stimulating this desire, and it is for this reason that consirlerable fluctuation necurs in the time of arrival of our earlier migrants as well as in the departure of our winter guests. A backward spring causes a general retardation of all migration that becomes less marked as the season advances, but every cold wave, even in the height of migration, checks farther advancement for the time being and detains transients at the localities where they happen to be when the adverse conditions arise. This is of great prac- 
tical value for the observer or hunter, as it affords him opportunity to find for a longer time and in greater numbers birds which under other, for them more favorable, conditions would have passed on at once or with little delay. The abundance and scarcity of rigrants in transit through our state is therefore largely dependent on the time at which prolonged cold or warm spells strike our region. Should the cold spell set in at the time when the bulk of ducks is present, the hunter will have cause to rejoice; but should their arrival be delayed and then be followed by a decided and extensive warm period, the bulk will pass on, proceeding on their way to the northern breeding grounds, and the hunters will find the season a poor one. This is the case with all transients and is the reason why we find certain birds common in one year and rare in another; it is especially noticeable in May when the presence of north-bound warblers, thrushes, and others, is greatly influenced, shortened or lengthened, by these warm and cold waves or spells.

A great diversity is also found in the seasonal distribution of precipitation which in a year amounts to thirty-four inches in the northwest and forty-six in the southeast. May and June are the months of greatest rrecipitation, and five inches of rain fall in each of these months throughout the state. This rainy season is generally followed by dry periods in July and August, when droughts of several weeks duration are not rare. But there are no fixed rules; while in some years no appreciable precipitation takes place from early July to September, in other year's rainy periods occur almost every week throughout summer. Statements of average precipitation, as of average temperature, give no insight into the weather conditions of a region. Four inches of rain mav fall within twenty-four hours and not a drop fall for a whole month, or the four inches may come down in installments of half an inch distributed over the same period.

The effect of such different conditions on bird life is remarkablc. Heavy storms with copious downpours in the height of the breeding season destroy immense numbers of broods, and long droughts make insect life so scarce that some species of birds find it impossible to provide enough food for their young. The increase or decrease in the number of individuals of a species is therefore often the direct result of favorable or unfavorable weather of the preceding summer.

While spring migration is chiefly influenced by temperature, fall migration is controlled in a large measure by precipitation. 
In years of drought during August and September, and such years are by no means rare, migrants proceed southward on their journey without much delay, because insect food of the kind they like is scarce, and all birds need water for drinking and bathing. The drying up of water courses and ponds has much to do with the early disappearance of birds from their breeding ground. The condition of our lakes and rivers governs the occurrence and abundance of water-birds in autumn. Should our rivers be so full as to cover all sandbanks and mud flats, waders will not remain with us; on the other hand, ducks will be rare when our ponds and sloughs are very low or dry, or when the water is too deep for dabbling. The presence or absence of particular species at certain seasons is therefore the direct result of the great variation in the seasonal distribution of precipitation.

In winter, too, it is the abundance or scarcity of snow on the ground that regulates the presence of birds more than the temperature does. Fortunately in most winters we cannot complain of too much snow, though the average snowfall for the state is said to be eight inches in the southeast, and thirty inches in the northwest. First snows usually do not fall before the middle of November; but here, too, the exceptions are almost as frequent as the rule. Snow once covered the ground at St. Louis as early as November 5 and did not entirely disappear from the north sides of houses until the middle of April (1881). In another year (1889) there, was no precipitation of any kind during the entire fall and winter until the first of January, 1890, when exceedingly heavy rain and wind storms followed. Snows falling before Christmas are usually light and drifted by the accompanying cold and high winds. Such snows do not affect bird life seriously, because they leave much ground uncovered and accessible to the ensuing sunshine. The worst kind of snow, that which is introduced or followed by freezing rain and sleet, falls mostly between the fifth of January and tenth of February, generally in advance of our severest polar waves whose low temperature preserves the icy crust almost intact for days and weels.s. They are naturally very destructive to bird life, the more so the further southward they cxtend and the longer they last. It was one of these periods that came near exterminating our castern bluebirds in February 1895.

The deepest snows fall in the latter part of winter, from the last of February to the first of April, but remain on the ground 
but a few days, giving way to the bright sunshine and strong winds following in their wake.

\section{TOPOGRAPHY.}

Missouri has three topographic divisions: the prairie region in the north and central west, the Ozark region in the south, and the lowlands in the southeast. There is a sharp line separating the lowlands from the Ozarks, but the dividing line between the other two regions is indistinet, following in the main the Missouri River westward to Boonville, there turning southwestward through Clinton, Appleton City, and Nevada to Lamar, leaving the state where the Spring River crosses the line.

The Ozark region has its highest elevation in a plateau, a broad, comparatively even, stretch of high land, which reaches from Perry, Ste. Genevieve, and Jefferson Counties southwestward to the southwest corner of the state. It attains a height of $1100^{\prime}$ in St. Francois Co., 1600' in Iron and Reynolds Cos., 1400' in Dent, 1700' in Wright and 1550' in Stone, Barry and Taney Counties. This upland is not a contiguous stretch, but is interrupted by shallow, rather wide troughs and by broad areas where the water disappears and runs in underground channels; but all the drainage of the Ozarks goes from this divide either north to the Missouri and Meramee Rivers or south to the White and Arkansas Rivers, a very small area only being drained eastwardly direet into the Mississippi River.

In the region immediately adjoining the plateau the streams have cut deep valleys and narrow gorges with innumerable ravines. This is the most rugged part of the whole region, the valleys reaching their maximum depth about midway between the plateau and the border subregion with bluffs and eliffs 300 feet high in places.

The Ozark border subregion is the hilly belt inclosing the Ozarks, being less rugged, less stony, but broken up more or less, and sloping gradually down to the prairie region or terminating on the east and north in the bluffs of the Mississippi and Missouri Rivers. 'The prairie region has never been a true, treeless prairic; its name is applied simply because its topography is of the same type as that of all the prairie regions of the Mississippi Valley; it is in fact the eastern border of the 
vast sloping plain which stretches from the foot of the Rocky Mountains to the Mississippi River. It is lowest along the border line of the Ozarks and along its eastern edge which fronts the Mississippi River, rising from $800^{\prime}$ along this belt to $1100^{\prime}$ south of Kansas City and to $1200^{\prime}$ near the northwestern eorner of the state. It is a gently undulating plain of rich soil, largely brought there by glacial action and thus differing greatly from that of southern Missouri, which is the result of decomposed native rocks. The valleys in the prairie region are true flood plains with flat floors, eut into soft shale, generally broad with gently sloping sides and extremely tortuous channels. All the valleys were originally heavily wooded, and remnants of the primeval forests are still found in the Mississippi and Missouri River bottoms and on their bluffs, but most of the timber of the prairie region has been removed, leaving only thin strips of woods along the streams with oceasional artificial groves. Tree growth of variable size and quality once eovered the entire Ozark region, heavy and of valuable kind in the valleys and along hillsides, low and of little value on the dry ridges and flats west of the Pine and White Oak region. The best parts of all the valleys have long been cleared and are devoted to agricultural pursuits; everywhere, high and low, the best timber is being rapidly cut out and removed; whole stretches have been transformed into orchards, and farms are springing up everywhere, even on the remotest hilltops. But there is still a vast amount of tree growth, so much so that, looking over the country from some eminence in the Ozarks, the eye meets hardly anything but vast stretches of woodland for miles and miles in all directions. The character of these woods is rather disappointing, for upon close inspection it is found to be of little commercial value, consisting in large part of medium-sized and small Blackjack and Post Oaks. Formerly Pine trees (Pinus echinata) grew in large quantities on silicious ground along the divide and southern slope of the Ozarks from St. Francois Co. to Taney Co., but they are mostly gone or disappearing at a rapid rate, being replaced only by scrub-oaks with no prospect for a continuation of pine woods in any part of the region, as the growth of Pinus echinata is too slow to make planting profitable and the annual burning over of the forest floor has prevented natural reproduction.

The flood-plains of the Missouri and Mississippi Rivers and the bluffs bordering them play such an important part in the dis- 
tribution of vegetable and animal life that they deserve a detailed description.

Where the Missouri River enters the state at the northwest corner it meanders for sixty miles through a flood plain of from six to ten miles in width with low, gently sloping bluffs hardly 100 feet high anywhere. The alluvial land on the Missouri side extends over a large area, eovering one-third of the counties of Atchison and Holt, and smaller areas of Andrew, Buchanan and Pealt Counties. All these bottoms were originally thickly timbered with Walnut, Maple, Sycamore, Cottonwood, Elm, Hickory, Oak, Hackberry, Willow, Locust, Boxelder, etc. Below the Nebraska-Kansas line the river eneounters harder rock and the floodplain narrows to three or four miles, while the bluffs rise to almost three times their height for a hundred miles, down to near Lexington in Lafayette Co. From there to Glasgow, running through soft shale, the river has carved out a flood plain from six to ten miles in width between low bluffs hardly 100 feet high. Rich alluvial bottoms, in some parts of a marshy nature, and ranging from one to three miles in width, extend for one hundred miles along the great bend of the river in Saline Co. and comprise one-third of the area of Carroll Co. From Glasgow to St. Charles the Missouri River flows without many windings through hard limestone in a floodplain less than three miles, in some places only two miles wide between steep bluffs 300 and more feet in height.

The floodplain of the Mississippi River is generally broader than that of the Missouri River, but less than one-half of it is on the Missouri side, the current of the river being mostly near the bluffs of its western shore. The width of the floodplain where the river reaches the state in the northeast, is about eight miles, with bluffs of 250 feet above low water. Bottomland up to three miles wide, some protected by levees, some subject to overfilow, extends through three counties, Clark, Lewis, and Marion. At Hannibal hard limestone causes the floodplain to contract, reaching its minimum width of three to four miles at Louisiana with bluffs over 400 feet high, closely followed by the stream through most of Ralls and Pike counties. In Lincoln Co. the alluvial botton widens again on our side with land partly protected by levees, partly subject to overflow, and reaches its maximum width in St. Charles Co., where all land east of St. Charles, St. Peters and St. Paul is alluvial, much of it marshy and dotted with ponds and lakes connected by sloughs. 
From the mouth of the Illinois River to Alton, a stretch of sixteen miles, the shore on the Illinois side is a wall of eliffs from 100 to 150 feet in height, formerly, and in less degree still the home of interesting birds with feeding grounds mostly on our side of the river. There is some bottom land in the northern portion of St. Louis Co., but from the City of St. Louis to the city of Cape Girardeau very little lowland is found on our side, as the river washes the foot of the bluffs nearly all along-bluffs which in many places attain the dignity of cliffs similar to those abore Alton on the Illinois side. At Cape Girardeau the Mississippi enters the great alluvial plain, of which the seven counties in the southeastern corner of Missouri form a part, and through which the mighty river, together with the waters of the Ohio winds in a wide belt with frequent changes of its channel and the formation of cut-offs, islands and lakes.

The most pronounced physiographic area of Missouri is the swampy region of the southeast. There, remnants of the most magnificent forests are still in existence, though continually encroached upon, and, since the region is now traversed by several railroads, it can be only a question of a few years when but a shadow of its sublime beauty will be left. It is the home of the Bald Cypress, the Water Tupelo, the Sweet Gum and Planertree; a pararlise for the ornithologist as well as the botanist who fincis there representatives of the Floridian and Texan floras; a bonanza for the herpetologist and entomologist.

Terminated northward by abrupt blufis along a north-east south-west line from Cape Girardeau to where the Current River crosses the state line in Ripley Co., the alluvial plain cover's about seven counties with an elevation of less than $\$ 00$ feet above sea level and from ten to twenty feet above the Niscissippi River at low-water. A number of rivers and bayous, connected in the eastem portion with the Mississippi, in the western with the St. Francis River, divide into ridges and islands and yearly inundate a large portion of the area when high water overflows their shallow beds for weeks and months at a time. Thus, Little River, which in very dry summers has hardly enough watcr to earry a canoe, reaches often a width of from six to seven miles; this is also the width of the St. Francis River with its parallel-running sloughs or arms.

Peninsula of Missouri is called that part of the southeast which extends from latitude $36^{\circ} 30^{\prime}$ south to $36^{\circ}$. With the exception of a narrow strip of sandy ridge between Little and St. Francis 
Rivers the whole region is low and a large part of it under water exeept in late summer and early fall, or in unusually dry seasons. Originally nine-tenths of the whole area was overgrown with a dense forest, the sandy ridge ealled Grand Prairie being the only part not fully covered with tree growth. Trees of magnificent size grew here by the millions; Cottonwoods and Cypresses attained gigantie dimensions; Sweet or Red Gums had taken possession of high levels, called islands; while the Bali Cypress occupied the region of the regular yearly overilow, and the Tupelos took to the sloughs and rivers themselves. Together with the Sweet Gums holding the higher levels were different kinds of Oak (White, Cow, Red, Shingle, Overcup and Willow Oaks), Red Maples, Elm, White Ash, Sycamore, Pecan, Mockernut, Shagbark Hickory, Haekberry, Sassafras, Black Gum, Tulip, Mulberry, Boxelder, Catalpa, Holly, and others. Dogwoods, Redbud, Papaw, Hazel, Spieebush, and Hereules Club were plentiful among the lower tree growth intertwined with a large variety of elimbers, among them Crossvine, Wistaria, Muscadine, Berchemia. Smilax and Cocculus. In the sloughs were Itea, Leitneria, Planera, Micania and many others assisting the broad belts of Polygonum densiflorum and Zizania miliacea to oeeupy the sides, while Nelumbo, Nymphea and Nuphar eorered the deeper portions, filling the whole expanse of the water with plant growth.

Excepting the presence of eane-brakes (Arundinaria) in its southern portion, the Peninsula does not differ essentially from the rest of the alluvial southeast in any of its physieal features, but, having eseaped the so-called civilization longest, retained the primeval conditions longest, and only since the railroads began to penetrate the region ten years ago is it slowly but surcly changing its former peculiarly wild and interesting character into one of devastation and desolation. Not only that the best timber is being removed, but hundreds of thousands of giant trees are girclled in the expectation of making the sancly soil agriculturally available. Levee-building and ditching is going on along the Mississippi River; lakes have been drained and mueh land has been protected from highwater in the Mississippi; the whole region is in a state of transformation; lumbering and the saw mills have attracted a population whose chief diversion is found in fishing and hunting, in devastating and destroying; surely the Peninsula will soon eease to be the paradise of the naturalist and hunter. Dueks, of which 150,000 were killed in a 
single winter (1893-94) on the Big Lake and shipped from Hornersville, still visit the region in large numbers in their migrations and many remain in mild winters, but the resident game birds such as the Turkey, and summer residents like the Wood Duck and Hooded Merganser are decreasing rapidly and will, like the Ivorybill, the Snakebird, the Canada Goose, several kinds of ducks and herons, the Bald Eagle and Osprey, in fact like most birds of larger size, disappear and become, as far as their beeding in that part of Missouri is concerned, exterminated.

\section{DECREASE OF BIRDS.}

There is no doubt that the gun is the main factor in the rapid disappearance of all the larger birds. No amount of instruction and law-making will prevent the killing of hawks and owls by farmer's and hunters, especially the latter, who sees in every large bird an enemy of his game, a competitor in the chase or fishery.

The reduction in the number of the smaller birds is the resuit of quite different causes-causes which camnot be removed because they are the unavoidable consequences of the transformation of a wild, thinly inhabited land into a highly cultivated, thickly settled one. With the felling of the trees, tree-inhabiting wild creatures necessarily disappear; with the draining of the lowlands, marsh birds cannot be expected any more; the drying-up of the lakes diverts their animal life to other regions, the removal of certain plants from a place makes the presence of eertain kinds of animal life impossible. When we consicier how much one organism is dependent on others, we do not wonder that an annihilation of many forms of animal life, high and low, is inseparably bound up with such a change as deforestation and subsequent cultivation. While we see a few birds which formerly lived exclusively in the forest accommodate themselves to the changed eonditions and put up with substitutes, such as orchards and artificial groves, many of the true forest-loving birds invariably disappear with the forest and become exterminated as far as that partieular locality is concerned. Not counting the scrub-oak barrens of the Ozarks as forest, because very few woodland birds find a home in them, we can say that only 25 per cent. of the former forest area is left as such at present, and that therefore 75 per cent. of most of the woodland birds of Missouri have gone since the white man began to settle in the state. But de- 
forestation is still going on, on even a larger scale than ever before. There may come a time when forestry steps in and takes care of the remaining woodland, and men may cven begin to plant new forests as they do in other countries, but such artificial groves compare with the primeval forests as docs a cornfield with a marsh or rrairie. Many birds now at home in the forest would feel themselves perfect strangers in such a highly cultivated tract of tree growth. There will be no great variety of trees, no twiners and vines of any kinds, no underbrush and thickets of brambles and briars, no decaying tree-tops and no prostrate monarchs of the forest crumbing into dust. The floor of the tract will offer no shelter and no hiding places for the nests of ground-builders: no thickets will harbor the many different songsters, which cannot exist without them; no canopy of low trees overgrown with climbers will eonceal, as it now so effectively does, the cradles of cur summer guests, and wood-peckers will find no insect-infested trees to yield them food and homes. There will be a desolation and stillness throughout these woods that even the few birds piesent will hardiy have the courage to break. Next to the vanishing of the woodland bird comes that of the marsh bird, whose doom is sealed by the draining of the lowland along our rivers and the transformation of lakes and swampy tracts into cornfields. These are no substitute for sedges, reeds, and flags and the manifold vegetation associated with them; nor will the pond and lake dwellers return after their watery haunts have yielded to the plow and harrow. Where do they go? IVe do not know; some of the smaller birds nay betake themselves to meadows, but the great majority disappear forever from the locality and the extermination of some of these species as breeders in our state is rapidly approaching. Those species of birds which frequent the thickets along the edge of woods and the vegetation which fringes the watercourses have a better chance to enclure for a while, but these too will constantly be reduced in numbers by the adoption of the ideal clean culture, which does away with all plant growth from fences and roads, and removes even the last remnants along the creeks and small wet-weather branches.

The universally deplored decrease of insectivorous and songbirds, generally laid at the door of the egg-collector and the boy with the gun, is therefore easily explained as the direct and inevitable result of the progress of civilization, which not only changes the physical features of the land, but also introduces 
and propagates enemies of the existing fauna not known before. The cat and the dog are responsible for the killing of niany of our choicest pets, which like the Bluebirds confidingly seek our protection to be sadly disappointed by lodsing their young ones to the cat as soon as they leave the nest. Some dogs are as bad as cats in destroying the broods of birds nesting on the ground. Besides the cat and the dog the hog does the greatest harm to birds which habitually make their nests on or near the ground. In parts of our state where the only woodpatch left standing is given to pasturing swine, no ground nester can long survive, and we find these species now entirely wanting in localities where they used to becommon. Cattle, horses and sheep involuntarily inflict losses on birds frequenting their pastures by trampling on their nests or disturbing them in the act of incubating. There are still other ways of destruction unavoidably connected with the tilling or burning over of land at a time when some birds have already nested on the ground and those which escape the fire and the plow may be demolished by the scythe or mower later on. It is easy to see why birds must become scarcer and scarcer, and that it will require all the protection man is able to give to keep them from a lamentable state of rarity.

\section{BIRD PROTECTION.}

It would be wrong to understand by bird protection simply the restraint from killing them. We have to actively assist them in the battle against adversities. It is not yet too late to save remnants of original forests from destruction; men of means, corporations, or associations of men, should establish such bird reserves in all parts of the state wherever forests remain. All that is required is a strong fence and a guard to keep out the dog and the hog, the cattle and the cat, the axe and the fire, and all other bird enemies, and allow only those persons to enter who appreciate the rare privilege.

Land owners and their tenants should be more sparing with axe and fire than they are now; before removing trees, stumps, vines, thickets and hedges they should consider whether it would not be possible to leave them for the birds, especially trees which have already served them for a home. Some birds, and among them the most useful ones, habitually nest in holes in trees; such birds can be helped by setting up bird boxes in trees or on poles in suitable places about the garden, park or orchard. 
Birds which nest in thickets can be assisted by planting shrubs and bushes and allowing them to grow thick enough for a bird to hide its nest there. Such birds once attracted will return, like those which build in holes, to the same place every year. Another way of attracting birds to one's premises is by planting wild fruit trees, especially Wild Cherry and Red Mulberry trees wherever shade and ornamental trees are wanted. It is not only a boon for our little feathered friends, but it keeps them away from our cultivated fruit, for birds need fruit of some kind for their diet, and, being deprived by man of their former wild fruit, they seek a substitute in our orchards, gardens and vineyards.

Our new game, bird and fish protection law of 1905 is as good as can be desired at present, but the enforcement of such a law depends so much on public sentiment that it remains to be seen how much good it will do. A great mistake has been made in framing Section 8 in which the word Chickenhawk is used among birds excluded from protection. Ornithologists do not recognize any particular species under that name, while hunters and others call every large hawk a chickenhawk. By thus inserting the word chickenhawk among birds to be killed, our legislators have doomed the fate of our most useful mice-destroyers, namely the Marsh Hawk, the Red-tailed, Red-shouldered, Broad-winged, and Rough-legged Hawks. All these are commonly known as chickenhawks, though they hardly ever catch chickens, while the Cooper's and Sharp-shinned Hawks, which really do the damage, are but seldom seen, because they hide in the woods and appear and disappear on their foraging expeditions with such lightning rapidity that they fall seldom to the gun of the hunter who takes pride in killing the slow mouse-hunting species which frequent the fields and perch on fence-posts. The proper thing to do would be to except from protection only the individual caught in the act of stealing, because it cannot be expected that anyone not a trained ornithologist can at first sight distinguish the harmful from the useful species.

Section 8 excepts from protection also the Goshawk and the Great Horned Owl, but the first is a very rare transient visitant, and the latter would never catch a chicken in a cold winter night, if our farmers would properly care for their fowls and keep them in hen-houses during the winter nights. Crows and English Sparrows should, I think, only be destroyed where they do actual damage, but not on general principle. In most parts of our 
state Crows do more good than harm, and if farmers were not prejudiced against them-partly on account of their black garb -and would investigate before passing judgment, they would often find that the damage with which they charge the crow is really done by other animals unseen because nocturnal.

The English sparrow does not need much protection. Nature has endowed it with so much sagacity and other useful qualities for self-preservation that its future is safe; and many persons are found who like the bird in spite of everything said against it. It is not true that they drive away our native birds. Until lately every plea for bird protection had to be based on their economic value. The aim of the investigator was to express in dollars and cents the benefit which a species bestows on husbandry by destroying its enemies, animal and vegetable. On the other hand he had to find out exactly what injury a bird does to man by appropriating things belonging to him, or which he claims as his own because of his superiority in the world of creation. Now the time is coming when one can plead for birds on esthetic grounds without asking, does the actual benefit really outweigh the damage? Or, is the number of insects killed really sufficiently large to pay for the fruit it eats? Or, still worse, what is the percentage of beneficial insects in the insect diet of each particular species? Should a species not be classed among the noxious animals, because it was found to destroy 60 per cent. of beneficial insects against only 40 per cent. of injurious ones?

There may have been a time when the American farmer could ill afford to lose a bushel of corn, a peck of cherries or something of equally small value with which to pay for the pleasure of being surrounded by bird life all the year round. May be he lacked the esthetic sense which brings the greatest happiness in the enjoyment of the beautiful. At present there are many willing and even eager to make sacrifices in order to secure the opportunity for the purest of enjoyments, the admiration of the wonderful works of creation, and certainly not the least among them is the bird! 


\section{Order PYGOPODES. Diving Birds.}

\section{Suborder Podicipedes.}

Family Podicipidae. Grebes.

[1. Aechmophorus occidentalis (Lawr.) -Western Grebe.] Podiceps occidentalis.

Geog. Dist.-Western North America from central Mexico to western Manitoba, Assiniboia, Alberta and British Columbia; eastward casually to Ontario, Wisconsin, Nebraska, Kansas. Breeds from North Dakota northward, chiefly in Assiniboia and Alberta. Winters mainly along the Pacific coast from British Columbia southward.

It has been taken near Omaha, Nebraska, less than fifty miles north of our state line, also at Lawrence, Kan., about the same distance from the western boundary (November 3, 1887), and probably occurs as an irregular visitant on the Missouri River along our western border.

2. Colymbus holboellit (Reinh.). Holboell's Grebe.

Podiceps rubricollis. Podiceps griseigena holboelli. Podiceps holboellii. Podiceps cristatus. American Red-necked Grebe.

Geog. Dist.-Northern North America, Greenland and eastern Asia. Breeds from lat. $46^{\circ}$ in Minnesota (Elbow Lake and Leech Lake) and from northern North Dakota to the Arctic Ocean, and winters in the United States to South Carolina and southern California.

Was taken in western Missouri by Dr. P. R. Hoy in the spring of 1854 and may still visit our state, but is said to have become rare everywhere.

3. Colymbus auritus Linn. Horned Grebe.

Podiceps cornutus. Dytes auritus.

Geog. Dist.-Northern Hemisphere. Breeds from northern Wisconsin and northern Nebraska northward, and winters along the Atlantic and Gulf Coasts and in California, migrating through the United States at large.

Not recorded from western Missouri, but in the eastern part of the state formerly a fairly common transient visitant in April, 
October and November. Two males in Mr. Hurter's collection were taken April 13 and November 27, 1877, near St. Louis.

\section{Colymbus nigricollis californicus (Heerm.). American} Eared Grebe.

Colymbus auritus. Podiceps auritus (in Nuttall and Audubon). Podiceps auritus californicus (in Coues' Key, 1872). Colymbus californicus (Grinnell). California Grebe. Horned Grebe.

Geog. Dist.-Western North America from the Mississippi to the Pacific and from Central America to Great Slave Lake. Breeds in colonies in suitable localities throughout its range, but has suffered greatly from persecution by plume hunters.

In Missouri formerly a common transient visitant from April 9 to May 3, and from September 22 to November 2, but much scarcer now; more common west than east.

*6. Podilymbus podiceps (Linn.). Pied-billed Grebe.

Colymbus podiceps. Podiceps carolinensis. Carolina Grebe. Thick-billed Grebe. Hell-diver. Da'bchick. Dipper. Water-witch.

Geog. Dist.-North and South America except extreme northern and southern parts. Breeds throughout its range. Winters in southern states and southward.

In Missouri by far the commonest of the family. May be found in its migrations in spring and fall on all waters, on rapidly flowing rivers, and even on small ponds. The first arrive in southeast Missouri early in March, at St. Louis the last of March, and in northern Missouri early in April. The bulk is present in April, but migration lasts till early in May. Fall migration takes place from the middle of September until the end of November, chiefly in October. Formerly a common breeder in all reedy lakes throughout the state, but with drainage and persecution it is becoming rarer every year.

Suborder Cepphi. Loons and Auks.

Family Gavindae. Loons.

7. Gavia imber (Gumn.). Loon.

Urinator immer. Colymbus torquatus. Colymbus glacialis. Great Northern Diver. Walloon.

Geog. Dist.- Northern part of northern hemisphere. Breeds from northern United States northward to Greenland and Alaska, 
and winters along the Gulf of Mexico and in Lower California; also along the Atlantic coast from Massachusetts southward.

During their migrations Loons are sometimes found on our larger lakes and rivers in every part of the state from the first week of April to the first of May, and from October 20 to November 20 , but this being the height of the duck-hunting season, they cannot stay long anywhere and pass on rapidly.

9. [Gavia ARctica (Linn.). Black-throated Loon.]

Urinator arcticus. Colymbus arcticus. Aretic Loon. Arctic Diver.

Geog. Dist.-Northern part of northern hemisphere. Breeds in aretic regions and migrates south in winter to northern United States east of the Rocky Mountains, but apparently extremely rare everywhere on this continent. Students should carefully examine all loons in winter dress, in which they resemble each other extremely. Size is too variable in this family to be a distinguishing feature. Red-throated Loons may easily be separated by the tarsus being longer than the middle toe with claw, but the Common and Black-throated Loons, so different in their beautiful summer dress, can only be told apart by exact measurement of the distance from the base of the culmen to the anterior point of the loral feathers, which is greater than the distance from the latter point to the anterior border of the nostrils in the Common Loon, and not greater in the Black-throated Loon.

\section{Gavis lumme (Gumn.). Red-throated Loon.}

Urinalor lumme. Colymbus sepientrionalis.

Geog. Dist.-Northern part of northern hemisphere. Brecds from New Brunswick and New Foundland to Greenland and through the arctic regions to Alaska. In winter south to United States, coastwise to Florida and southern California and in the interior chiefly on the Great Lakes and larger rivers.

Two specimens in winter dress taken November 3, 1902, near New Haven, Mo., are in the collection of Mr. Chas. Eimbeck. It has been taken twice on the Missouri near Omaha in spring and fall (April 6, 1897 and September 28, 1894) and Mr. W. E. Praeger writes me that there is a mounted specimen in Keokuk said to have been shot on the Des Moines River near Ottumwa, Ia. 
Order LONGIPENNES. Long-winged Swimmers.

Family Stercorarimae. Skuas and Jaegers.

37. Stercorarius parasiticus (Linn.). Parasitic Jaeger.

Lestris Richardsonii. Richardson's Jaeger (dark phase).

Geog. Dist.-Northern part of northern hemisphere. Breeds from Greenland along the Arctic sea-coast to the Behring Sea and the Aleutian Islands. In winter from New York, Illinois and California southward to Brazil and in the Old World to South Africa.

In migration it has repeatedly been taken in Colorado, in Kansas (young male near Lawrence, October 10, 1898, in Nebraska, September 13, 1898, near Lincoln), and Mr. W. E. Praeger has in his collection an immature male shot on the Des Moines rapids October 6, 1896. Mr. J. D. Kastendieck of Billings, Christian Co., Mo., has in his collection of finely mounted birds a specimen taken on a mill-pond near Billings in August 1905. It was alive when he secured it and he kept it several days, feeding it on fresh meat and large insects, which it took eagerly from his hand.

Family Laridae. Gulls and Terns.

Subfamily Larinae. Gulls.

40. Rissa tridactyla (Linn.). Kittiwake.

Larus tridactylus.

Geog. Dist.-Circumpolar regions in summer. In America in winter south to the Middle States and Great Lakes (Wisconsin, Illinois, Minnesota, Wyoming and Colorado).

As a rare straggler this species is placed in our list by $\mathrm{Mr}$. John A. Bryant, who took a specimen near Kansas City in 1897.

51. Larus argentatus Brünn. Herring Gull.

Larus argentatus smithsonianus. American Herring Gull. Sea Gull.

Geog. Dist.-Northern hemisphere, including the whole of North America. Breeds from Maine, the Great Lakes, Minnesota and British Columbia to the Arctic Sea. In winter along the whole coast of California, the Atlantic coast, the Great Lakes and the larger rivers south to the Gulf Coast, Cuba and Mexico. 
In Missouri the Herring Gull is a transient and winter visitant, most common in early spring and in fall from October 20 to November 20. On the Mississippi and lower Missouri Rivers it may be seen from September 20 to May 5 in varying numbers, leaving us entirely only when the rivers are frozen and returning with the breaking up of the ice. It frequents the lower Missouri River, but is rare in the western part of the state.

\section{Larus delawarensis Ord. Ring-billed Gull.}

Larus zonorhynchus Richards. Common American Gull.

Geog. Dist.-North America at large, but chiefly in the interior. Breeds from the northern United States northward and winters coastwise from British Columbia and Long Island southward, also on the Lower Mississippi and in the Gulf States.

In Missouri the Ring-billed Gull is a common transient visitant in March and April, October and November. It is much more common in western Missouri than the Herring Gull.

59. Larus Franklinit Sw. \& Rich. Franklin's Gull.

Chroicocephalus franklini. Franklin's Rosy Gull.

Geog. Dist.--Interior of North America, migrating chiefly west of the Mississippi River, and breeding from northern United States northward, mostly in the prairie region of Manitoba and Assiniboia. Winters from the mouth of the Mississippi southward through Mexico and Central America to Peru.

In Missouri formerly a regular transient visitant throughout April and in October and November; now rarely seen in the eastern part of the state.

60. Larus philadelphia (Ord). Bonaparte's Gull.

Larus bonapartei. Chroicocephalus philadelphia.

Geog. Dist.-Whole of North America, breeding north of the United States, mostly in the wooded region from Hudson Bay to the Yukon marshes and British Columbia. In winter from our southern states to western Mexico.

In eastern Missouri a regular transient visitant, formerly common, the latter part of March and early in April, and through October.

62. Xema sabinit (Sab.). Sabine's Gull.

Larus sabinii. Fork-tailed Gull.

Geog. Dist.-Arctic regions. In North America south in 
winter to New York, the Great Lakes, Great Salt Lake and California; casual to Montana, Colorado, Nebraska (September); Iowa, October 15, 1891, and October 12, 1894; Kansas, Bahama and coast of Peru.

It finds a place in our list on the strength of three specimens taken by Mr. Chas. K. Worthen of Warsaw, Ill., in September 1900, on the Mississippi River, bounding Clark Co., Mo., in the northeast corner of the state.

Subfamily Sterninae. Terns.

64. Sterna Caspia Pallas. Caspian Tern.

Sterna tschegrava.

Geog. Dist.--Nearly cosmopolitan. In North America breeding locally from Newfoundland to Virginia, and in colonies on small islands in Lake Michigan, in Texas, Louisiana and Nevada. In migration widely scattered, having been taken in Wyoming, Nebraska, Minnesota, Iowa, Ohio, ete.

Mr. Chas. K. Worthen of Warsaw, Ill, writes me that he took Caspian Terns a number of times during the latter part of May and fore part of June, usually while flying over a big sandbar in the Mississippi River not far from the Missouri shore. Mr. W. E. Praeger saw Caspian Terns frequently at Keokuk in the fall of 1887 and ' 88 from September 9 to October 15. Mr. John D. Kastendiek has a fine specinen in his collection of mounted birds. It was shot on the mill pond at Billings, Christian Co., about April or May, 1895.

69. Sterna Fonsteri Nuttall. Forster's Tern.

Sterna havelli. Havell's Tern.

Geog. Dist.-North America generally. Breeds locally in the United States from the Atlantic to the Pacific, but chiefly in the interior north to latitude 570. In winter southward to Brazil.

In Missouri, both east and west, formerly a fairly common, now rather rare, transient visitant in April and May, and again in September and October.

70. Sterna hirundo Linn. Common Tern.

Sterna wilsonii. Sterna fuviatilis. Common Sea Swallow. Wilson's Tern.

Geog. Dist.--Northern hemisphere. In America chiefly along the Atlantic coast north to the Aretic coast and west on large 
lakes to Alberta. Breeds from Arizona, Texas and Florida northward. Winters from Virginia southward and along the Gulf coast to western Mexico.

In Missouri now a rare transient visitant in the second half of May. In the eastern part of the state it was formerly much more common than in the western, but it has also been taken at St. Joseph by Mr. Sidney S. Wilson (May 28, 1895).

*74. Sterna antillarum (Less.). Least Tern.

Sterna minuta. Sterna argentea. Sterna superciliaris. Sterna frenata.

Geog. Dist.-Northern South America, northward to southern California, Dakota and New England, breeding throughout its range, and wintering south of the United States.

The Least Tern was formerly a not uncommon summer resident on sandbars in the Mississippi and Missouri Rivers from May 1 to September 15 , but nonc have been seen the last few years, though they may still breed in small numbers within the state.

*77. Hydrochelidon nigra surinamensis (Guel.). Black Tem.

Hydrochelidon lariformis. Sterna nigra. Hydrochelidon fissipes. Sterna fissipes. Hydrochelidon plumbea. Short-tailed Tern.

Geog. Dist.-Temperate and tropical America from Alaska to Chile and Brazil. Breeds from the middle United States west of the Alleghanies northward, the marshy districts of Manitoba and Assiniboia being its chief breeding grounds at present.

In Missouri the Black Tern was formerly a fairly common breeder in marshy regions, but it is now rare except in migration, when fairly common from the end of April to the last of May and in August and September, sometimes to October 21.

Order STEGANOPODES. Totipalmate Swimmers.

Family Anhingidae. Darters.

*118. Anhinga anhinga (Linn.). Anhinga.

Plotus anhinga. Plotus melanogaster. Darter. Snakebird. Water Turkey.

Geog. Dist.-Tropical and subtropical America, north in United States to South Carolina on the Atlantic coast and southern Missouri in the Mississippi Valley. 
With drainage, deforestation and settlement of swampy regions this species is fast receding southward. Twenty years ago Mr. E. W. Nelson observed the Anhinga in the vicinity of Cairo, where Hennicott had reported it as of common occurrence in 1865. In 1896 it was still a fairly common summer resident in the watery region of Dunklin and Pemiskot Counties, but since the railroads penetrated the Peninsula in all directions and made it easily accessible to the lumberman and hunter, there is little hope for a continuance of its abode in Missouri, though a few pairs may still be found in secluded spots.

\section{Family Phalacrocoracidae. Cormorants.}

120. Phalacrocorax dilophus (Swain.). Double-crested Cormorant.

Pelecanus (Carbo) dilophus. Graculus dilophus.

Geog. Dist.-Eastern North America, north to Great Slave Lake, east to Utah and Wyoming. Breeds chiefly north of United States and winters from the Gulf States southward.

In Missouri Cormorants are still common in migration from the midclle of March till the end of May and in fall from September 25 to November 15, chiefly in April and October. They are rarer in the western part of the state.

*120a. Phalacrocorax dilophus floridanus (Aud.). Florida Cormorant.

Phalacrocorax floridanus. Southern Double-crested Cormorant.

Geog. Dist.-South Atlantic and Gulf States and lower Mississippi Valley to the mouth of the Ohio.

In the Peninsula of Missouri Cormorants are still breeding in considerable numbers. When feeding young in their nests in the high timber along the Mississippi, troops of them are continually flying to and from the distant feeding grounds in the bayous or lakes and sloughs in the Little River and St. Francis basin.

[121. Phalacrocorax mexicanus (Brandt). Mexican Cormorant].

Carbo mexicanus.

Geog. Dist.-Mexico, Western Gulf States and lower Mississippi Valley to mouth of the Ohio. It was taken near Cairo in the 
spring of 1879 and twice in Kansas. (April 2, 1872, at Lawrence, and in Mitchell Co.)

Being a very common summer resident in several sections of Louisiana it seems probable that roving individuals, following the example of several other speeies of birds, may straggle up the Mississippi Valley into our state. Students should be on the lookout for them when visiting the Peninsula in summer or early autumn.

Family Pelecanidae. Pelieans.

125. Pelecanus erythrorhynchos Gmel. American White Pelican.

P. americanus. P. trachyrhynchus. P. onocrotalus.

Geog. Dist.-North America; rare in northeastem states, common in the interior; north to Mackenzie River, lat. 61。. Breeds from Minnesota, Great Salt Lake, Utah and Eagle Lake, Cal., northward. Winters south of United States to Central America.

In Missouri the White Pelican is a regular and still conmon transient visitant in April, September and October, oceurring in large flocks on the Mississippi and Missouri Rivers, where it finds a safe retreat on the immense sandbars in the middle of these rivers. For feeding purposes it visits also smaller bodies of water, but retires to the large rivers for rest and roost. Small parties are sometimes seen in summer (May, June, July and August)-individuals which either did not get to breeding, or have been disturbed and driven from their nesting grounds. In his Preliminary Report on the Animals of the Mississippi Bottom near Quiney, Mr. H. Garman mentions the presence of a flock of forty Pelicans in August 18S8; also troops of Cormorants. This tends to show that these species may wander about before their regular time for migration has eome. From the notes of early explorers it is evident that Pelicans were formerly abundant along the lower Missouri River. Under date of April 28, 1833, Max, Prince zu Wied writes: "One hundred or more Pelicans go north in wedge or erescent shape." and the next day, April 29, 1833, he saw a still larger flock. Audubon often speaks of flocks of Pelieans when he went up the Missouri in April, 1843, and saw some as late as May 9 near the eomer of the state. Also on his way back in October, 1843, he mentions great flocks of geese 
and pelicans on the 10th near Leavenworth and an abundance of geese and pelicans on the 13th near Brunswick. Mr. Jasper Blines of Alexandria, Mo., writes in Forest and Stream, vol. 39, p. 294: "On September 25, 1892, immense flocks of pelicans appeared along the Mississippi (Clark Co.) pursuing their annual migration southward. One flock I observed was a quarter of a mile in length and contained hundreds of these great birds. The pelicans are the only wild fowl which seem to maintain their average numbers."

Order ANSERES. Lamellirostral Swimmers.

Family Anatidae. Ducks, Geese and Swans.

Subfamily Merginae. Mergansers.

129. Merganser americanus (Cass.). American Merganser.

Mergus americanus. Mergus merganser. Ameriean Sheldrake. Fish Duck.

Goosander. Buff-breasted Sheldrake.

Geog. Dist.-North America generally. Breeds now chiefly from Newfoundland, Labrador and British Columbia northward, locally also in northern United States, and sparingly in the mountainous regions of the West. Winters through the southern United States to the Gulf coast.

In Missouri the Merganser is a common transient visitant and one of the earliest migrants in spring, coming as soon as the ice breaks up; some remain in mild winters.

130. Merganser serrator (Linn.). Red-breasted Merganser. Mergus serrator. Red-breasted Sheldrake. Fishduck.

Geog. Dist.-Northern portion of northern hemisphere. Breeds from Newfoundland and Greenland through the wooded region to the Aleutian Islands; south sparingly to the northern United States. Winters in the United States, mostly coastwise, rare in the interior.

A specimen, of this, in Missouri apparently rare species, was taken near Kansas City, April 20, 1902, by Mr. John A. Bryant. Mr. W. E. Praeger took two females near Keokuk, February 14, 1890 , and Mr. Edmonde S. Currier of Keokuk gives the following dates: February 21 and 23, 1892, March 28, 1899, May 4, 1902, October 19, 1902, November 12, 1896. 
*131. Lophodytes cucullatus (Linn.). Hooded Merganser.

Mergus cucullatus. Sawbill. Hooded Sheldrake. Fishduck.

Geog. Dist.-Whole North America; breeding through most of its range; south in winter to Cuba and Mexico; a few remain in the southern states.

In Missouri the Hooded Merganser is, in favorable localities, a fairly common summer resident from early in March till November. The heavily wooded bottoms of the larger rivers and the swampy southeastern counties are the breeding grounds of this species, often mistaken for Wood Ducks, especially the females and young ones, sometimes even the males, the dress of which is much plainer in summer than in early spring. More common and generally distributed are the transient visitants in spring and fall. Some stay in mild winters, but as a rule the last leave the state in December and return in March.

Subfamily Anatinae. River Ducks.

*132. Anas boshas Linn. Mallard.

Anas domestica.

Geog. Dist.-Northern hemisphere. Breeds chiefly north of United States from Greenland to Alaska. Formerly a breeder in most of the United States west of the Alleghanies and north of the Ohio Valley, it is now rare in the Eastern, but still common in some of the Western States. Winters through the Southern States to central Mexico and Lower California, rarely to Central Anerica and Cuba.

In Missouri the Mallard is a very common transient visitant; in spring from the breaking up of the ice in January or February to about April 25, most numerous in the second and third week of March; in fall from early in Septenber to the middle of December. The bulk generally does not come before October 10 to northern Missouri, and not before October 20 to the southeast, and leaves the former about November 20 and the latter nearly a month later. Many remain in open winters, and even in severe winters a few are known to have wintered in northern Missouri, taking refuge in air holes caused by warm springs in rivers and visiting cornfields in the daytime. A few pairs still find safe breeding grounds in the large tracts of spartina grass in the marshes of north Missouri, but, as the open season for duck 
shooting is now extended to the first of May, there is no hope for an increase in their numbers.

\section{Anas obscura Gmel. Black Duck.}

Black Mallard. Dusky Duck.

Geog. Dist.-Eastern North America, breeding formerly in the northern United States east of the Mississippi River, now chiefly from Newfoundland and the Maritime Provinces to Hudson Bay and west to the Red River. In migration it has been found as far west as eastern Nebraska and eastern Kansas. Its chief winter home is on the Atlantic coast from Long Island to northern Florida, though quite a number winter in Louisiana.

In Missouri the Black Duck is sometimes, though rather rarely, taken with Mallards in their migrations to and from their winter habitat. Dates of their eapture run from Mareh 10 to April 10 and from October 13 to December 1.

133a. Anas obscura rubripes Brewster. Red-legged Black Duck.

Geog. Dist.-The breeding range of this lately separated subspecies includes northern Labrador and the Hudson Bay region. The southern limit has not yet been determined. It winters somewhat farther north than the Black Duck, as far north as Nova Scotia and as far south as South Carolina. In migration it has been taken as far west as Nebraska, and as far south as Mississippi Co., Arkansas (Nov. 5, 1887), but nothing is known of its winter home in the interior.

A specimen in the possession of $\mathrm{Mr}$. Emmett Cole of Malta Bend was taken in Saline Co. and, if students will pay more attention to the separation of the different subspecies, this more northern form of Black Duck will probably be found to be a regular transient visitant in our state.

135. Chaulelasmus streperus Linn. Gadwall.

Anas strepera. Gray Duck.

Geog. Dist.-Northern hemisphere. The breeding range in America extended formerly from the upper Mississippi Valley to the Pacific, now ehiefly through the prairie region of Canada, north to lat. 68\%, and from the Rocky Mountains west to British Columbia, south to Colorado and nearly throughout California. It is rare, even as a mere straggler, in Ontario and Quebec and 
the northern Atlantic States. It winters from North Carolina to Florida, but chiefly in the lower Mississippi Valley and thence westward to Central Mexico and Lower California.

In Missouri the Gadwall is a fairly common transient visitant from the last of February to the end of April, when they are generally found in pairs. They used to be summer residents in northern Missouri, and only a few years ago were considered rare breeders in Clark Co., Mo., by Mr. Ed. S. Currier of Keokuk, Ia. In the southward migration they appear about the middle of October and remain in the southeast well into December.

\section{Mareca penelope Linn. Widgeon.}

Anas penelope.

Geog. Dist.-Northern part of Old World and Aleutian Islands. In America a frequent straggler, chiefly along the Atlantic coast from Greenland and Newfoundland to Florida. In the interior it has been reported from Ohio, Indiana, Illinois, Michigan, Wisconsin, and Nebraska. On the Pacific coast it has occurred several times in California, British Columbia and Alaska. A remarkable fact is, that, while the Atlantic coast records are nearly all made in winter (October 20 to February 5) and none later than March 25, those of the interior are all made in spring (March 23 to April 18).

Mr. Frank Schwarz of St. Louis mounted a male which was killed by a hunter in the vicinity of St. Louis, April 10, 1905.

137. Mareca americana Gmel. Baldpate.

Anas americana. American Widgeon.

Geog. Dist.-Whole of North America with the exception of its northeastern part, being only a straggler north of the Great Lakes and Chesapeake Bay. Breeds sparingly on the plains of Kansas, Nebraska and South Dakota, more commonly in Colorado, Utah and Nevada (formerly east to Indiana and Wisconsin), now chiefly from Minnesota, North Dakota, Manitoba and Assiniboia northwestward to the Aretic circle. In Alaska to Kotzebue Sound. South to Oregon. It winters in California, and in the East from Virginia and the Ohio River to Cuba, Mexico and Guatemala.

In Missouri the Baldpate is a common transient visitant. It is present in spring from the last of February in the southeast, and from the middle of March in the north, to the middle of 
April, occasionally to the end of the month (April 28, 1904, Kansas City, Bryant). Those seen in April are generally in pairs. In fall migration they reach us early in October, are common from October 10 to November 20; some linger on the southeastern waters well into winter.

Some writers use the term "wintering" when a species is seen in every month of winter, but this is misleading. Many birds stay with us until the first part of January when the severest period of winter begins, are gone for over a month, but retuin to us before the end of February, at which time the strength of winter is broken and the ice of the rivers has moved out.

139. Nettion Carolinensis (Gmel.). Green-winged Teal.

Anas crccca. Anas carolinensis. Querquedula carolinensis.

Geog. Dist.-Whole of North America. Breeds from New Brunswick, Newfoundland and Labrador west to British Columbia, northwest to Kotzebue Sound and throughout the Aleutian Islands, north to Mackenzie River. Also in the mountains of the western United States, and formerly in many localities of the Eastern States from northern Illinois and Nebraska northward. At present the main breeding grounds extend from Manitoba northwestward to Lake Athabaska. It winters along the Pacific coast from British Columbia to Jalisco and through the. southern Atlantic and Gulf States to southern Mexico, rarely to Cuba and Honduras.

In Missouri the Green-winged Teal is a very common transient visitant. It returns to the southeast soon after the middle of February, to the marshes of north Missouri and the western part of the state about the first of March. The bulk is present from March 10 to 25, but the last has not leit the state before a month later. In autumn the first begin to reappear between September 15 and 22 and from the end of the month to the middle of $\mathrm{No}$ vember they may be found in many parts of the state. They are mostly all gone by the middle of December, but in mild winters a few may be found in January.

140. Querquedula discors (Linn.). Blue-iwinged Teal. Anas discors.

Geog. Dist.-North America, chiefly east of Rocky Mountains and west of Great Lakes. Breeds locally from northern Ohio, southern Indiana, Missouri, Texas and New Mexico, but mainly 
from northern United States northward to Saskatchewan; rarely east to New England and Newfoundland and Labrador, or west to Nevada, central Oregon, British Columbia and Alaska. It winters from the South Atlantic and Gulf States south through the West Indies and Mexico to Central and northern South America as far as Brazil and Chile.

In Missouri it is a very common transient visitant. The first reach the southeast early in March, sometimes even in February. On the marshes near St. Louis the first are usually taken between the 10th and 17th of March and in northern Missouri about a week later. The bulk is present from Narch 15 to April 15 and the last transients are found about April 25. Pairs seen in the latter part of April or in Nay intend to remain and would breed if let alone: but, as they are hunted wherever seen, they probably succeed but seldom in rearing a brood. The last instance of eggs being found in the state is given by Mr. E. S. Currier, who states that on May 23, 1889, a nest was found by boys in Clark Co., and an egg was brought to Mr. F. M. Crawford at Wayland. A pair of Bluewings was scen by me June 17, 1906, near Malta Bend, Saline Co., and others in the same month near Peruque, St. Charles Co. The first flocks of southbound Bluewings have been seen in northern Missouri on the first of September, but the bulk is with us from September 15 to October 25 , and some linger for another month (November 22, 1905, St. Charles Co.).

\section{Querquedula cyanoptera (Vieillot). Cinnamon Teal.}

Anas cyanoptera. Red-breasted Teal.

Geog. Dist.-Western America from Mexico to British Columbia and from Peru to the Straits of Magellan and the Falkland Islands. Breeds east to liyoming and southern Texas, straggling in migration into the Mississippi Valley, and wintering south of the United States, chiefly in Mexico.

An occasional straggler in Missouri it has been taken as far east as the vicinity of St. Louis, as several mounted specimens in private collections attest. It is said to occur with flocks of Bluewinged Teals.

142. Spatula clypeata (Limn.). Shoveller.

Anas clypcata. Spoon-bill. Spoon-billed Duck.

Geog. Dist.- Northern hemisphere; in America, rare on the Atlantic coast north of the Potomac, conmon from Indiana 
westward to California. Breeding formerly in most of its range, it is now restricted in the United States to western plains and mountain parks. In Canada it breeds from Manitoba west to central British Columbia and northwest to Kotzebue Sound, being most abundant between $51^{\circ}$ and $54^{\circ}$ lat. It winters from Virginia to Georgia and through the Gulf states to Mexico and Guatemala, rarely to Florida and the West Indies or South America.

In Missouri the Shoveller is a fairly common transient visitant from March 10 to April 25 and from October 1 to November 20. In mild weather earlier and later dates have been obtained in central Missouri (February 20, 1903, New Haven, Dr. Eimbeck, and December 4, 1902, St. Charles Co.), and in southeastern Missouri some have been taken in January. The Shoveller is known to have bred in the state (Clark Co., E. S. Currier), and even now pairs are seen late in April or even in May (May 16, 1905, Warrensburg), which would probabły breed, if conditions were favorable.

143. Dafila acuta (Linn.). Pintail.

Anas acuta. Anas caudacuta. Sprig. Sprigtail.

Geog. Dist.-Northern hemisphere; breeding sparingly in western United States, but chiefly from Manitoba, Assiniboia and British Columbia northward to the Aretic coast, rarely eastward from Hudson Bay to New Brunswick. It is the commonest duek in Alaska. It winters from Virginia and Louisiana southward to Cuba and through Mexico to Costa Rica, rarely to Panama. Also along the Pacific coast from British Columbia south through California.

In Missouri the Sprig, as it is commonly called, is a very common transient visitant in spring and fall, lingering long with us in spring, but passing through rapiclly in fall. Flocks of Sprigs may be found in one part of the state or another from the end of January to April 20, and from October 1 to December 15, more commonly from March 1 to 25, and from October 10 to November 25. With Mallards the Sprigs are the first ducks to return to us as soon as the snow clisappears from the ground and before the ice has broken up in the lakes or left the rivers. They appeared near St. Louis February 24, 1905, three days before the ice broke up in the Mississippi and only four days after the first thaw followed one of our severest winters, in which the ground was covered for four weeks with a solicl sheet of icy snow. The 
first appear even at our northern state line seldom later than the end of February.

*144. Aix sponsa (Linn.). Wood Duck.

Anas sponsa. Dendronessa sponsa. Summer Duck.

Geog. Dist.-North America from latitude 540 southward to Cuba and southern California. Breeds through most of its range and winters in the South Atlantic and Gulf States and in California, returning early to the breeding grounds.

As a transient visitant it is still fairly common from March 15 to April 20, and from October 20 to November 25. It is also a fairly common summer resident in all heavily wooded river bottoms, especially in those of the Peninsula, and many sueceed in rearing broods in spite of continuous persecution. In August and September gatherings of from 75 to 100 birds may yet be found in favorite secluded spots in our river bottoms, to which they repair daily for weeks, if not disturbed too much. They are early breeders, and young out of nest may be met with in the second week of May.

\section{Subfanily Fuligulinae. River Ducks.}

146. Arthya anericana (Eyt.). Redhead.

Anas ferina. Fuligula ferina. Fuligula americana. Pochard.

Geog. Dist.-North America to about latitude 54o, rare on the North Atlantic coast. Breeds from southern California sparingly to British Columbia and locally from Nebraska northward, most numerously in the reedy marshes of Manitoba, Assiniboia, Alberta and Saskatchewan. It winters from the coast of British Columbia and from the Potomae through the southern states southward to southern Mexico.

In Missouri the Redhead is a fairly common transient visitant from March 1 to April 10, exeeptionally earlier in February and even in January, or later (April 19, 1894, Currier) and in fall from October 15 to December 1 . While abundant in large flocks in spring, it is less often met with in the fall.

\section{Aythya vallisneria (Wils.). Canvas-back.} Anas vallisneria. Fuligula valisneria. White-back.

Geog. Dist.- Whole of North America; rare on north Atlantic coast, more plentiful from Quebec and Ontario westward to 
Alberta, where most abundant; northwestward to Sitka. Breeds locally from Minnesota, North Dakota, Colorado and Nevada northward. Winters from Fraser River to Mazatlan and from Chesapeake Bay and the Onio River southward through the southern states to central Mexico.

Though not rare the Canvas-back is a less regular transient visitant in Missouri than the Redhead and in smaller troops. It occurs sometimes in February, but mostly between March 1 and April 15, and in fall from October 25 to December 10, oftenest from the middle to the end of November.

148. Aythía marila (Linn.). Scaup Duck.

Aythya marila nearctica. Anas marila. Fuligula marila. Fulix marila Big Black-head. Big Blue-bill.

Geog. Dist.-Northern hemisphere; in America breeding from Minnesota and British Columbia throughout northwestern Canada to Kotzebue Sound and the Aleutian Islands, more commonly northward. Winters from the Aleutian Islands along the Pacific coast almost to Mexico, in the lower Mississippi Valley and abundantly from Long Island to Chesapeake Bay, less commonly along the South Atlantic and Gulf coast to southem Texas.

Like the Canvas-back, and even more so, the Big Blue-bill is irregular in its appearance in Missouri, and never oceurs in large flocks like its smaller cousin. Available dates of its capture on the marshes of northeastem Missouri range from February 28 to April 1 (One taken May 18 was probably a cripple). In fall from November 10 to December 5 .

149. Arthya affinis (Eyt.). Lesser Scaup Duck.

Fuligula affinis. Fulix affinis. Fuligula mariloides. Fuligula ininor. Fuligula marila in Audubon's works. Little Blue-bill. Little Blackhead.

Geog. Dist.-North America, breeding from the northern border of the United States northward through the prairie region to the Arctic Circle, and from Hudson Strait to the Yukon River: rarely in northern United States and on the Pacific coast. It winters in the South Atlantic States and southward to the Greater Antilles; it is especially common along the Gulf coast to Guatemala; less common in California.

In Missouri the Blue-bill is a very common transicnt visitant, occurring in large flocks from the last of February to the middle of April, and from October 1 to December 5 . Earliest for St. 
Charles Co., February 16, 1904; latest December 4, 1902. Earliest for Clark Co. (Currier), February 21, 1892; latest in spring, April 25, 1897: in fall, December 5, 1899. Pairs are occasionally seen in summer (June 1S, 1901, Clark Co., Currier, and June 17, 1906, in Saline Co.), but whether they breed has not been ascertained.

150. Aythya collaris (Donov.). Ring-necked Duck.

Anas collaris. Fulix collaris. Fuligula collaris. Anas fuligula. Anas (Fuligula) ruftorques. Ring-neck. Ring-bill. Blackjack.

Geog. Dist.-North America, rare on North Atlantic Coast. Breeding from southern Ninnesota and North Dakota northward to Lake Athabasca; sparingly west of the Rocky Mountains. In winter chiefly along the Gulf Coast to Central America and Cuba; north to the Carolinas and the Ohio River.

The Blackjack is a very common transient visitant in Missouri. The first arrive from the south about a week after the first Mallards and Sprigs have come. In short winters the species may be absent a few weeks only. In the vicinity of St. Louis the first have been noted February 18, 1898; in some years they were not seen before the middle of March, but usually varying numbers are frequenting the marshes of northeastern Missouri from Nlarch 10 to April 10, sometimes to the end of the month (April 2S, 1S93, Clark Co., Currier). Their presence in fall is also governed largely by the weather conditions. In 1903 they were plentiful in St. Charles Co. from October 3 till December 4; in other years they eame as late as October 20 and were gone a month later.

151. Clangula Clanglla americana (Bonap.). American Golden-eye.

Glaucionetta clangula americana. Fuligula clangula. Bucephala americana. Anas clangula (in Wilson). Clangula glaucium. Clangula vulgaris. Bucephala clangula. Whistler. Great Head. Garrot. Whistlewing.

Geog. Dist.-North America; breeding from Newfoundland, New England, northern Michigan, North Dakota, Montana and British Columbia northward in wooded regions to the Mackenzie River and Alaska. It winters abundantly on the Atlantic coast from the British Provinees to South Carolina, along the Pacific coast, and less commonly on the Gulf coast.

In Missouri the Whistle-wing is a frequent transient or winter 
visitant on the larger rivers. At Keokuk, which is situated on the Mississippi River at the foot of the rapids, Mr. E. S. Currier had the opportunity to observe it every winter for eleven years and found it in flocks of from 30 to 100 , sometimes much more numerous, as on January 17, 1903, and March 5, 1895, when a thousand were present. His dates of those first seen vary from November 9, 1895, to December 4,1892, and those for last seen from January 17,1903, to April 7,1899. A female in the Hurter collection was taken near St. Louis, January 1, 1875.

\section{Clangula islandica (Gmel.). Barrow's Golden-eye.}

Glaucionetta islandica. Anas islandica. Rocky Mountain Garrot.

Geog. Dist.-Northern North America; breeding from mountains of western United States and from Bay of Fundy to Greenland and Alaska. It winters around the Gulf of St. Lawrence, in the northern United States, the Rocky Mountains and on the Pacific coast south to central California.

Mr. E. S. Currier gives the species as rare, but occurring amongst the immense number of Golden-eyes which winter on the Des Moines rapids. Mr. WT. E. Praeger obtained a female shot March 27, 1888, on Lima Lake, Ill., a few miles east of the state line. In a letter sent to $\mathrm{Mr}$. R. Ridgway and published in Forest and Stream, vol. 36, p. 435, Mr. Frank W. Sparks of St. Louis writes under date of February 10, 1891: "This fall, while shooting at the same place (New Albany, southeast Missouri) I killed a specimen of Barrow's Golden-eye. Unfortunately this duck, or more properly drake, was half picked by one of the boys in camp when I discovered it. He is rare so far east, is he not?" To this Mr. R. Ridgway replied: "Regarding your capture of Barrow's Golden-eye in Missouri, this is not so remarkable, as specimens have previously been taken in the vicinity of St. Louis, in Kansas and southern Illinois. These localities represent, however, about the southern limit of the winter range of the species, which is a northern and not a western bird, as you seem to regard it."

153. Charitonetta albeola (Limn.). Buffle-head.

Anas albeola. Fuligula albeola. Clangula albeola. Bucephala albeola. Butterball. Dipper.

Geog. Dist.-North America; breeds from Maine, Ontario, Wisconsin, Wyoming and British Columbia northward in all the forest country to the upper Yukon. In winter along all coasts 
of the United States, and less regularly on the Great Lakes and larger rivers of the interior; south to Mexico and Lower California.

In Missouri the Butterball is a fairly common transient visitant in early spring and late fall. It is sometimes taken in February, even in the western and northern part of the state (February 5, 1904, Kansas City, Bryant; February 22, 1885, Keokuk, Praeger), but small troops are met with most frequently between March 1 and April 10, exceptionally later (May 4, 1892, Keokuk, Currier). In fall the earliest record is October 10, 1904, (Kansas City, Bryant) and the latest December 4, 1892 (Keokuk, Currier). The largest number of dates were obtained between October 10 and November 20.

\section{Harelda hemalis (Lim.). Old-squaw.}

Anas hyemalis. Clangula hyemalis. Harelda glacialis. Anas glacialis. Anas longicauda. Long-tailed Duck. South-southerly. Old-wife.

Geog. Dist.-Northern hemisphere; breeding along the Arctic coast, and wintering from the Aleutian chain down the whole Pacific coast to California, and on the Atlantic coast from St. Lawrence to North Carolina; less regularly on the Great Lakes and larger rivers of the interior south to the Ohio River, exeeptionally even to Louisiana (February 28, 1885, and February 13, 1899).

In Missouri an irregular winter visitant between November 20 and April 1. Old birds are always rare, but young birds are sometimes common.

155. Histrionicus histrionicus (Limn.). Harlequin Duck.

Anas histrionica. Fuligula histrionica. Histrionicus torqualus. Histrionicus minitus. Anas minuta.

Geog. Dist.--Northern North America, Iceland and Eastern Asia. Breeds in America from Newfoundland, Labrador and the east coast of Greenland, south of the Arctic Circle, on rapid streams of the interior west to Alaska and British Columbia, and in the mountains of the western United States south to lat. $38^{\circ}$. In winter irregularly to the northern United States from the coast of Maine to California, but everywhere rare and apparently on the decrease.

In Missouri a rare winter visitant. One was taken March 21, 1897, in Montgomery Co. by Mr. E. M. Parker, and another, taken near St. Louis, October 29, is in the Hurter collection. 
Near Omaha, Neb., it has been taken as early as September 16, 1893, and September 19, 1895 (Osprey vol. 3, p. 131).

\section{[162. Somateria spectabilis (Linn.). King Eider].}

Fuligula spectabilis.

Geog. Dist.-Northern part of northern hemisphere. Breeds in Arctic region from the Atlantic to Pacific; in America in winter south to New Jersey and the Great Lakes, rarely south to Georgia and California.

Mr. Wm. E. Praeger has in his collection a young male which was shot on the Mississippi River near Keokuk, November 10, 1894 (Auk, vol. 12, p. S6).

\section{Oidemia americana Swains. American Scoter.}

Anas nigra. Fuligula americana. Black Scoter. Sea Coot. Scoter Duck.

Geog. Dist.-Northern North America and eastern Asia. In summer in the Hudson Bay country, but breeding most abundantly on the Pacific coast from the Aleutian Islands to Kotzebue Sound and northeastern Asia. In winter to the coasts, lakes and larger rivers of the United States, chiefly north and eastward, rarely to lower Mississippi Valley and on the Pacific coast to California. Also in Japan.

Black Scoters in immature plumage are probably not as rare in Missouri as appears from captured specimens. They have repeatedly been taken in southeastern Nebraska, and Mr. W. E. Praeger obtained one at the Des Moines rapids near Keokuk, October 31, 1895. An immature specimen killed near St. Louis, November 24, 1875, is in the Hurter collection, and there is a report, though somewhat questionable, of a flock of fifty being seen May 2, 1S83, on a millet field near Anna, Union Co., in southern Illinois, feeding on the newly sown seed.

\section{Oidenia deglandi Bonap. White-winged Scoter.}

Anas fusca. Fuligula fusca. Oidemia fusca. Oidemia bimaculata. Oidemia velvetina. Melanetta velvetina. Oidemia fusca velvetina. Velvet Scoter. White-winged Coot. Black Surf Duck. Velvet Duck.

Geog. Dist.-Northern North America; breeding from Gulf of St. Lawrence to $59^{\circ}$ lat. in Labrador, and from North Dakota and Alberta to Hudson Bay and mouth of the Mackenzie River; less commonly from British Columbia to Kotzebue Sound and the coast of northeastern Siberia. In winter to the coast of the 
Pacifie from British Columbia to Lower California, and on the Atlantic from Nova Seotia to South Carolina, also on the Great Lakes and irregularly throughout the United States south to the Gulf Coast.

In Missouri a rather rare winter visitant on the Missouri and Mississippi Rivers. A male in the Hurter eollection was taken near St. Louis, October 18, 1883, and two in immature plumage, November 24, 1877. A female taken near Kansas City is in the Publie Museum of that city. Mr. W. E. Praeger has one in his collection taken October 26, 1895, on the Des Moines River near Keokuk. In southeastern Nebraska specimens were seeured Oetober 14, 1899, and December S, 1900.

\section{Oidemia perspicillata (Linn.). Surf Scotel.}

Anas perspicillata. Fuligule perspiciilatu. Peliometta perspicillata. Pelionette troulvidgii. Surf Duck. Sea Coot. Surf Coot. Gray Conts (young and females). Spectacled Coot. Skunkhead.

Geog. Dist.-North Ameriea; breecling from Newfoundland and Labrador (Greenland?) along the Aretic coast to Alaska. In winter along the Pacific Coast from the Aleutians to Lower California; on the Atlantic Coast from Maine to Florida, ehiefly from Massachusetts to North Carolina; in the interior throughout the United States irregularly as far south as Louisiana.

In Missouri a rare winter visitant. An immature speeimen taken near St. Louis, May 3, 1876, is in the Hurter eollection. Wr. Wm. E. Praeger has specimens taken near Keokuk, Oetober 19,1895 , and Oetober 22, 1596. A young male was secured Oetober 29, 1887, at Lawence, Kan., and one, also a male, at Lincoln, Neb., October 7, 1896.

\section{Erismatura jamaicensis (Gmel.). Ruddy Duck.}

Anas rubidus. Erismatura rubida. Fuligula rubida. Anas jamaicensis. Spine-tailed Duck. Bristle-tail. Fool Duck.

Geog. Dist.-From northern South Ameriea through the Greater Antilles and Central America to the Great Slavo Lake. Breeds locally throughout its range, but mainly in the reedy lakes of Manitoba, Assiniboia and Alberta. In winter to California, South Atlantie and Gulf States and southward.

In Missouri the Ruddy Duek is a fairly common, but generally distributed, transient visitant. In spring it is with us from the latter part of February (February 26, 1884, St. Louis) to the end of April (April 25, 1881, a fine male in the Hurter collection) 
and in fall from October 10 to November 20. According to $\mathrm{Mr}$. Hy. Nehrling the Ruddy Duck was formerly a rare breeder in southwestern Missouri.

\section{Subfamily Anserinae. Geese.}

\section{Chen hyperborea (Pall.). Lesser Snow Goose.}

Anser hyperboreus. Anser albatus. Chen hyperboreus albatus. Snow Goose. White Brant.

Geog. Dist.-Northeastern Asia and western North America to the Mississippi Valley. Breeds within the Aretic circle from Liverpool Bay to Alaska. In winter from British Columbia through the interior valleys to southern California, Mexico, Texas and Louisiana.

In Missouri the Snow Goose, often called Brant, is a fairly common, generally distributed transient visitant from the end of February (February 25, 18S4, St. Louis) to the middle of April (April 16, 1902, New Haven; April 17, 1894, Vernon Co.), chiefly in March, and in fall from October 10 to November 20.

169a. Chen hyperborea nivalis (Forst.). Greater Snow Goose. Anas hyperboreus. Chen hyperboreus nivalis.

Geog. Dist.-Eastern North America, east of the Mississippi River except the region north of Virginia, migrating in spring through Manitoba and eastern Assiniboia, in fall through western Assiniboia and Alberta. Breeds in Arctic regions and winters along Atlantic coast, the Gulf States, and irregularly in the Greater Antilles.

In Missouri a transient visitant of probably regular occurrence, together with intermediate forms, among troops of the former subspecies. Typical specimens have been secured by Mr. Chas. K. Worthen of Warsaw, Ill., several times on Lima Lake, and Mr. E. W. Nelson stated that he found the two subspecies in about equal numbers in Illinois, sometimes in separate flocks, or mixed with the other subspecies, and also with the Blue Goose. Dr Rud. M. Anderson writes in his Birds of Iowa on page 183: "On the basis of these measurements (78 skins collected in Iowa) only ten or twelve per cent. of the specimens from Iowa can definitely be considered as Greater Snow Geese, the remainder being the Lesser variety, with every grade of intermediates between. In the face of such perfect intergradation, the attempt to differ- 
entiate between the varieties seems to be almost a useless refincment."

169.1. Chen caerulescens (Linu.). Blue Goose.

Anas caerulescens. Anser caerulescens. Blue-winged Goose. Young of Snow Goose.

Geog. Dist.-Interior of North America. Breeding ground unknown but thought to be on eastern shores of Hudson Bay. In winter through Mississippi Valley to Gulf coast, chiefly west of the Mississippi River.

In Missouri the Blue Goose is a farly eommon transient visitant in spring in flocks by themselves or mixed with Snow Geese. Available dates run from March 17 to April 2; no fall record is at present at hand. Formerly considered to be the young or a colored phase of the Snow Goose, this species did not receive that measure of observers' attention which it deserves. Moreorer the young of the two species resemble each other perfectly in form and size, and enough in color to make identification at a distance difficult. Both, old and young, were formerly not rare in the St. Louis market. Two fine specimens of adult birds are in the Eimbeck, one in the Hurter collection and some in several other private collections in St. Louis.

171a. Anser albifrons gambel. (Hartl.). American Whitefronted Goose.

Anser gambeli. Anser albifrons. Anser frontalis. Speckle-belly. Laughing Goose.

Geog. Dist.-North America generally, rare on the Atlantic coast, common in migration in the Mississippi Valley and in the Pacifie States. Breeds in Greenland and on the mainland along the Aretic coast to the Yukon River. Winters from British Columbia to Cape St. Lucas and Jalisco, and from lower Mississippi Valley and southern Texas to northern Mexico; also in Cuba.

In Missouri the Speckle-belly, also called Brant by hunters, though less abundant than formerly, is still a fairly common transient visitant from early in March to the latter part of April, and in Oetober and the first half of November.

172. Branta Canadensis (Limn.). Canada Goose.

Anas canadensis. Bernicla canadensis. Wild Goose.

Geog. Dist.-North America; breeding from Tennessee, Arkansas, northern Colorado, southern Oregon, northward to and 
through the British Provinces from Newfoundland to British Columbia and northward to the Mackenzie River basin and the interior of Alaska. In winter to California and from Long Island, Ohio Valley and lower Missouri Valley southward through the south Atlantic and Gulf States. As the settlers of the country moved west and northward the breeding grounds of the goose were encroached upon. Its southern limits at present extend through the northern tier of states, but the bird will soon be driven from there as well as from the southern provinces of Canada.

In Missouri the Wild Goose is a common transient visitant and a not very rare winter resident, being present in larger or smaller numbers from early in October to the latter part of April, leaving the state entirely only for a short time during the severest winter weather when the ground is covered with snow and the rivers are frozen. When the first white men flocked into the state, they found the geese nesting all along the Mississippi and Missouri Rivers. In his "Reise durch Nord America" Prinz zu Wied tells us that he found on April 25, 1833 , a nest in a tree at the mouth of Nodaway River, and that the next day he met with a group of goslings guarded by their parents.

During the last decade of the past century the Peninsula of Missouri still harbored a small number of breeding pairs, usually nesting on cypress stumps in the overflow, 6 or 8 feet above the water. The natives hunted their eggs and young, and bevies of semi-domesticated Wild Geese were a common sight in Pemiscot and Dumklin Counties. Pairs thus reared were allowed to make their own nests in the fields of the farmer and incubated their eggs themselves, the gander keeping guard and boldly attacking all intruders. As there has been a great influx of settlers into that country cluring the last few years, it is probable that the clays of the Wild Goose breeding in Missouri are past, but some may still at least try to remain. Non-breeders are sometimes seen in northern Missouri long after the transients are all gone (May 3, 1887, St. Louis; May 18, 1902, New Haven; June 7, 1886, Mt. Carnel).

172a. Branta Canadensis hutchinsi (Rich.). Hutchin's Goose.

Anser hutchinsii. Bernicla hutchinsii. Little Wild Goose. Lesser Canada Goose.

Geog. Dist.-Western North Anerica; in the north-east to 
Hudson Bay region, rarely to the Atlantic coast. Breeds from Yukon Delta northward along the Arctic coast and islands and migrates through the western states and the Mississippi Valley to winter in California and the southem United States.

In Missouri a fairly common transient and winter visitant, generally in company with its larger cousin, from which it is readily distinguished by its much smaller size. The first Hutchin's Geese Audubon 'ver saw, he killed October 14, 1843, near Brunswick, Mo.

[172c. Branta Canadexsis minma Ridgw. Cackling Goose.] Branta minima.

Geog. Dist.-Coast of Alaska, chiefly about Norton Sound and Lower Yukon, migrating southward into western United States, east to Wisconsin.

A fine example of this very small Goose, killed in the vicinity of Quincy, Ill., and now in the bird collection of the Public Library, extends its range as a casual visitant to the eastern border of Missouri.

\section{Dendrocygna Fulva (Gmel.). Fulvous Tree-duck.}

Anas fulve. I'emelope mexierma.

Geog. Dist.-Southern border of United States; cast to eastern Louisiana (Rigolets Pass), north to central California (Marysville) and Nevada (Washoe Lake); south into Mexico. Occurs also in South America, southern Asia. Africa and Madagascar. Accidental in Washington (October 3, 1905, Grays Harbor); North Carolina (Swan Island, July, 1886).

Of its occurrence in Missouri we find the following record in Forest and Stream: vol. 36. p. 435: "St. Louis, Mo., Feb. 10, 1891. Dr. T. H. Bean. Dear Sir: While duck shooting last fall at New Albany, southeastern Missouri, I killed what was then to me a new duck, but which I have since identified as Dendrocygna fulca, a South American bird, if I have placed it right. Is not this a rare bird so far north? I have mounted the skin and would present it to the Smithsonian, if it will be of any use to that institution. Yours very truly, Frank W. Sparks." To this the following reply was added: "Smithsonian Institution, Washington, June 12, 1891. Mr. Frank W. Sparks, 2516 No. Broadway, St. Louis. Dear Sir: I write to thank you on behalf of the National Museum for the very fine specimen of the Fulvous 
Tree-duck, Dendrocygna fulva, which you had the kindness to present through Dr. Bean. Besides being a very acceptable specimen on account of its good preparation, it is particularly so from the very exceptional locality which it represents, being, so far as the Eastern United States are concerned, much the most northern example on record-Currituck Sound, N. C. (a single accidental specimen), Louisiana and Texas being the most northern localities for the species known to me, except in California where it is not uncommon as far north as Stockton. It has also been taken near Carson, Nev. Yours truly,

\section{R. Ridgway, Curator Dep't of Birds."}

Subfamily Cygninae. Swans.

180. Olor columbianus (Ord). Whistling Swan.

Anas columbianus. Olor americanus. Cygnus americanus. Cygnus bewickii. Cygnus ferus. Cygnus musicus. American Swan.

Geog. Dist.- North America; breeding along the coast of the Arctic Sea from Baffinland and Nottingham Island to Alaska, where it has been found as far south as $58^{\circ}$ (Becharof Lake). Winters on Pacific coast from British Columbia to southern California; on the Atlantic coast from New Jersey to Florida; rare in the interior and Gulf States.

In Missouri a rare transient visitant in early spring (March 26, 1898, St. Joseph, Wilson; March 27, 1894, Keokuk, Currier; March 24, 1885, St. Louis: March 16, Hurter collection). Seldom met with in fall (October $S$ and 9, Keokuk, Praeger). It may not be out of place to remind students, as Dr. Coues does in his Birds of the North-west, page 546, "that the yellow spot on the bill is not constant, in young birds especially, often no trace can be observed. In such cases the species would be distinguishable from $O$. buccinator by the smaller size, fewer tail feathers, and shorter, differently shaped bill."

181. Olor buccinator (Rich.). Trumpeter Swan.

Cygnus buccinator.

Geog. Dist.-Interior of North Anerica, breeding formerly from Iowa and Nebraska through the North-west Territories, now from about $60^{\circ}$ to the Arctic Ocean. Winters from British Columbia to southern California and migrates through the Mis- 
sissippi Valley to the Gulf of Mexico. Rare or casual on the Atlantic coast.

In Missouri the Trumpeter Swan is a regular, formerly fairly common, now rather rare, transient visitant from the middle of February to the middle of April, chiefly in March. The innumerable large and small lakes in the flood plains of the Mississippi and Missouri Rivers offer temporary resting places for the passing swans, which wander in small troops and, where not molested, remain sometimes for weeks on favorite feeding grounds. On a small lake on a St. Charles Co. game preserve a party of eight remained in 1895 from March 15 to April 9; and they are known to return to the same lake every spring. In autumn these lakes are usually too shallow and small to suit swans, though they attract geese and ducks, as well as other water birds and waders. As this species is known to have bred in Iowa and Nebraska the swans, which Audubon saw May 4, 1843, on the Missouri River between Leavenworth and St. Joseph may have been on or near their nesting grounds. That swans bred formerly also in northeastern Missouri is well known to old hunters. Mr. Jasper Blines of Alexandria wrote October 31, 1888, in Forest and Stream vol. 31, p. 343: "What has become of the swan? This noble fowl was tolerably plentiful here in former times and even hatched its brood along the densely covered shores of our lowland lakes. But they have bidden us good-bye and have sought climes more genial, and their musical voice is no more heard in our land."

Order HERODIONES. Herons, Storks, Ibises, etc.

Suborder Ibides. Spoonbills and Ibises.

Family IBIDidat. Ibises.

[184. Guara alba (Linn.). White Ibis.]

Scolopax alba. Tantalus albus. Ibis alba. Eudocinus albus.

Geog. Dist.- South Atlantic and Gulf States to West Indies and northern South America; north to North Carolina, southern Illinois, Great Salt Lake and Lower California, casually to Long Island, Connecticut and South Dakota.

There are two White Ibises in immature plumage in collections at Quincy, Illinois, one in the Seaman collection in the High 
School, the other in the Public Library. Upon inquiry it was found that both were killed at the same time out of a flock of four by $\mathrm{Mr}$. Slingerland of Quincy in the neighborhood of that city. This extends the range of the species in the Mississippi Valley northward to the region of northern Missouri.

[186. Plegadis autumnalis (Hasselq.). Glossy Ibis.]

Tantalus falcinellus. Ibis and Plegadis falcinellus. Ibis Ordii. Ibis falcinellus var. ordii. Green Ibis (young). Bay Ibis.

Geog. Dist.-Warmer parts of Old World and West Indies, irregularly to southeastern United States, wandering north along Atlantic coast to New England and in the Mississippi Valley to Nebraska (three specimens taken in eastern Nebraska near Omaha), and Wisconsin.

One in immature plumage was killed February 27, 1880, within a few miles of St. Louis in the Illinois bottom, and is now in the Hurter collection of Washington University of St. Louis.

187. Plegadis guarauna (Linn.). White-faced Glossy Ibis. Scolopax guarauna. Ibis and Tantalus guarauna. Ibis thalassinus (young).

Geog. Dist.--Northern South America through West Indies and Mexico to Texas, southwestern Louisiana, California, straggling northward to British Columbia, Oregon, Wyoming, Kansas and Nebraska. Also found breeding (June 26, 1894, and June 22, 1895), at Heron Lake, Minn.

'The Kansas records are one in fall, 1879, near Lawrence; one near Wichita, October 17, 1890; and one near McPherson, April 29, 1891. Of the three specimens taken in Nebraska, two were killed near Omaha, August 19, 1893, and April 6, 1897. There is also a record from Calhoun Co., Ia., where one was killed out of a flock of thirteen in April 1891. In a case of mounted bircls presented to the Cuivre Hunting Club by one of its former members, Mr. John T. Davis, is a fine specimen of a White-faced Glossy Ibis in adult plumage. All birds in the case were taken on the club grounds in St. Charles Co., but unfortunately dates of capture have not been preserved. 
Suborder Ciconiae. Storks, ete.

Family Ciconimae. Storks and IVood Ibises.

Subfamily Tantalinae. Wood Ibises.

188. Tantalus loculator Linn. Wood Ibis.

Water Turkey. Colorado Turkey. Gourdhead.

Geog. Dist.-From southern South America to southeastern California, Arizona, and the Gulf coast, wandering in summer northward through the lower Mississippi Valley to Missouri, irregularly to Utah, Colorado, Indiana and Wisconsin, casually to Ohio, Pennsylvania and New York.

The Gourdhead, as it is called by the natives, is a regular summer visitant in the Peninsula of Missouri from July to September, occurring in troops of from ten to thirty. Some years these troops follow the Mississippi River into northern Missouri, visiting the lakes of the bottom land, rarely ascending the lower Missouri River. Dr. A. F. Eimbeck observed them but onee in thirty-five years, a flock of seven at New Haven, August 11 to September 11, 1902.

Suborder Herodii. Herons, Egrets, Bitterns, etc.

Family Ardeidne. Herons, Bitterns, ete.

Subfamily Botaurinae. Bitterns.

*190. Botaurus lentiginosus (Montag.). American Bittern. Ardea stellaris canadensis. Botaurus minor. Ardea minor. B. mugitans. Stake Driver. Thunder Pump. Indian Pullet. Look-up.

Geog. Dist.-From Guatemala northward throughout the United States and in Canada to Hudson Bay and Mackenzie River, and from the Atlantic to the Pacific. Breeds in suitable localities in most parts of the United States, chiefly northward.

In Missouri the Bittern can still be regarded a fairly common summer resident and breeder in all marshes from about the first of April to the end of Oetober. In migration it may be met with in unexpected places, on small pools in the woodland, on the prairie, as well as on the broad marshes of the great flood plains, 
especially numerous in the St. Francis basin. In the more southern part of the state the first appear in March, but April and October are the months when the transient visitants are most common and generally distributed. A few linger through November. November 19, 1906, one was caught in the heart of St. Louis in a sleet storm unable to continue its flight, because covered with sleet and frozen rain. In the very backward spring of 1907 a transient individual was met with in Calvary Cemetery at St. Louis as late as May 9. Numerous examples are known, proving that such birds as Bitterns do not follow certain migration routes, but travel broadcast over the country. Mr. E. Seymour Woodruff found a Bittern on April 8, 1907, beside a small pool of rainwater in a shallow depression on top of the plateau in the woods of Shannon Co.

*191. Ardetta exilis (Gmel.). Least Bittern.

Ardea exilis. Little Bittern.

Geog. Dist.-Northern South America and West Indies to southern British Provinces. Breeds throughout the United States from Maine to southern Oregon, except in the mountainous regions of the West. Winters from the Gulf coast southward.

In Missouri the Least Bittern is a locally common summer resident from the middle of April in the south, and nearly a month later in the north, to September. It is a denizen of the reedy lakes and sloughs in the flood plains of the Mississippi and Missouri Rivers. Even where plentiful, they are seldom scen in the daytime, but become active toward evening, when they move about by clasping the reed stalks just above the water and flying from one part of the lake to another low over the plant growth. In the love season their peculiar chat-like note may often be heard coming from the dense reeds. Specimens taken near Springfield (Dr. D. T. Kizer) and at Billings (J. D. Kastendieck) show that the Least Bitterns do not follow the large rivers in their migrations, but cross the Ozarks.

Subfarnily Ardeinae. Herons and Egrets.

*194. Ardea herodias Linn. Great Blue Heron.

Blue Crane. Fish Heron.

Geog. Dist.-From northern South America to Nova Scotia, Quebec, Manitoba and British Columbia, rarely to the Northwest 
Territories and Alaska. Breeds locally throughout its range and winters from the Gulf and South Atlantic States and California southward.

The Blue Crane, as this bird is generally callet, is a fairly common summer resident in Missouri from the middle of March, occasionally earlier, to November. It is surprising that a bird so large and subjected to such universal persecution still survives in the numbers in which we find it to-day. During the breeding season there is probably no county in the state where some individuals cannot be seen flying from the distant nest to some favorite feeding grounds. Perhaps the largest numbers may be seen in the flood plains of the great rivers, where whole colonies nest on the highest trees along the shores or on the islands; but they are also found in the remotest counties of the Ozarks, where they build their nests in the high trees of the valleys in one county and have their feeding grounds ten or more miles away in another county.

*196. Herodias egretta (Gmel.). American Egret.

Arden egretta. Herolias alba egretta. White Crane. White Heron.

Geog. Dist.-Originally whole of South America, Central America, West Indies, and in North America throughout the United States, excepting the mountainous regions of the West, to southern Canada. Now greatly reduced in numbers and rare where formerly common. Breeds now locally from Virginia and Missouri southward and wanders after the breeding season northward. Winters from the Gulf States southward.

Until the early nineties, when the plume craze reached our country and every trapper became a plume hunter, the swamps of the southeast harbored large colonies with hundreds of breeding Egrets. After a very few years of slaughter the birds had grown so searee that the good men had to give up hunting cranes as an unprofitable occupation. As late as 1900 , small numbers were still breeding in colonies together with Great Blue Herons on islands in the Mississippi as far north as St. Charles and Lincoln Counties, making the shallow lakes in the marshes their feeding grounds, but none have been seen there the last few years. Twenty years ago hundreds congregated around these lakes in August and early September and many ascended the lower Missouri Valley on these roving expeditions at least as far as New Haven (Dr. Eimbeck). 
197. Egretta candidissima (Gmel.). Snowy Heron.

Ardea candidissima. Garzetta candidissima. Little White Egret.

Geog. Dist.-Formerly from Argentina to the northern United States, casually to Nova Scotia, Ontario and British Columbia, breeding from Virginia and southern Illinois southward. Now nearly exterminated in the United States.

Like other herons the Snowy used to wander northward in the Mississippi River flood plain after the breeding season and was a conmon bird on the marshes of St. Charles Co. in August and September, but none have been seen there for the past ten years. A few may have survived the slaughter and destruction of their colonies in southeastern Missouri and with proper protection may again become an ornament of our late summer landscape. Mr. J. D. Kastendieck shot some on the mill pond at Billings in August and September 1895, and Mr. W. E. Praeger reports them as having occurred near Keokuk, but Snowy Herons seem never to have visited the more northern and the western part of the state in large numbers.

[198. Dichromanassa Rufescens (Gmel.). Reddish Egret.

Ardea rufescens. Demiegretta rufa. Dichromanassa rufa. Ardea rufa. Ardea rufescens. Ardea pealei. Demiegretta pealei. Peale's Egret (white phase.)

Geog. Dist.-Gulf States, Mexico (both coasts), Central America and West Indies, north to the Ohio in the Mississippi Valley.

Observed and found quite common during the last week of August 1875 in the vicinity of Cairo, Ill., by Mr. E. W. Nelson.

199. Hydranassa tricolor Ruficollis (Gosse). Louisiana Heron.

Ardea ludoviciana. Demiegretta ludoviciana. Hydranassa tricolor ludoviciana. Ardea leucogastra v. leucophrymna. Ardea tricolor ruficollis.

Geog. Dist.-Gulf States, Mexico, Central America and West Indies; casually northward to New Jersey and Indiana.

Mr. E. S. Currier killed one near Sand Ridge, Clark Co., Mo., April 13, 1890, as it rose from a small prairie pond.

200. Florida Caerulea (Linn.). Little Blue Heron.

Ardea caerulea. Little White Heron (young).

Geog. Dist.-From northern South America through the West Indies and Central America to eastern United States; breeding 
in the southern states, formerly to southwestern Indiana and Missouri and wandering after the breeding season northward to the more northern states, accidentally to Wisconsin, Maine and Nova Scotia. It winters south of the United States, returning to Louisiana about the middle of March and to Missouri more than a month later (April 30, 1880, Hurter collection).

Not known to breed in Missouri at present, but appears in the Peninsula in large troops, composed entirely of birds of the year, late in July or early in August, remaining till September. Some of them wander up the Mississippi to the region of the mouth of the Illinois River, irregularly, farther north (Warsaw, Ill., Worthen) or along the Missouri River north to southern Nebraska. It has been taken in Platte Co., Mo., opposite Leavenworth, Kan., by Mr. A. Lange, and a specimen in the Kansas City Public Museum was taken near that city.

\section{*201. Butorides virescens (Linm.). Green Heron.}

\section{Ardea virescens. Shytepoke. Fly-up-the-creek.}

Geog. Dist.-From northern South America, through the West Indies and Central America to southern Ontario, throughout the United States east of the Great Plains and in California and Oregon. Breeds throughout its range and winters south of the United States.

In Missouri the Green Heron is a common summer visitant of general distribution not confined to low or swampy regions like other herons, but frequenting wooded streams and ponds, nesting sometimes far away from water on cultivated land, frequently in orchards in small colonies of from six to ten nests on one acre. It arrives in southern Missouri about the 10th of April, in central and northern parts from one to two weeks later (Shannon Co., April 10, 1904; Vernon Co., April 15, 1894; St. Louis Co., April 17, 1886; Kansas City, April 18, 1904; Keokuk, average date, April 25). It leaves the breeding grounds in family groups during September and very few are seen after the first of October. (Latest record October 13, 1896, Keokuk, Currier.)

*202. Nycticorax nycticorax naevius (Bodd.). Black-crowned Night Heron.

Ardea naevia. Nyctiardea grisea naevia. Nyctiardea gardeni. NightRaven. Qua-bird. Squawk. Quawk.

Geog. Dist.-Nearly the whole of South America, parts of West Indies, and through the United States to New Brunswick, 
Ontario and Manitoba. Breeds throughout its range and winters from California and the Gulf Coast southward.

In Missouri formerly a locally numerous, now a greatly reduced, summer resident in the flood plains of the larger rivers, chiefly the Mississippi, from April 10 to October 10. More generally distributed in migration, especially in early fall, when young birds may be met with at ponds and pools far away from their usual haunts. When on wing in the twilight going from nesting to distant feeding grounds they resemble ravens, which, with some similarity in their croak, has given rise to the popular name, Night Raven.

*203. Nictanassa violacea (Linn.). Yellow-crowned Night Heron.

Nycticorax violacea. Nyctiardea violacea. Nycterodius violaceus.

Geog. Dist.-From Brazil to the South Atlantic and Gulf States; in the Mississippi Valley to the mouth of the Ohio; on the Pacific coast to Lower California; casually north to Massachusetts, Minnesota, Nebraska and Colorado. Breeds in all parts of its regular summer range, which formerly extended to Indiana, Illinois and Kansas. Winters south of the United States to which it returns in March.

Thirty-three years ago the breeding range of the Yellowcrowned Night Heron extended up the Illinois bottom to the mouth of the Illinois River. A young of the year in the Hurter collection was captured opposite St. Louis, July 12, 1873, and an adult, April 10. Ten years ago they were still fairly common summer residents in the Peninsula, but of late they have become few and their total extermination as breeders in the state is fast approaching.

Order PALUDICOLAE. Cranes, Rails, etc.

Suborder Grues. Cranes.

Family Gruidae. Cranes.

204. Grus americana (Linn.). Whooping Crane.

Ardea americana. Grus hoyanus (young). Hooping Crane.

Geog. Dist.-Interior of North America from Mexico, Texas and Florida to Saskatchewan and Athabasca, migrating chiefly 
through the Mississippi Valley and breeding formerly in the northern United States and Canada from the Red River to the Rocky Mountains, now driven to the northernmost portions of its range by the irresistible encroachment of civilization.

Available records of its occurrence in Missouri are few. The first for the state is that of Dr. P. R. Hoy in his "Journal of an Exploration of western Missouri" under date of April 18, 1854. One in the Hurter collection of birds taken in the vicinity of St. Louis is dated March 17, 1S84. Mrs. Musik reported five cranes seen at Mount Carmel, Audrain Co., March 25, 1885. Mr. Hy. Nehrling saw 26 Whooping Cranes at Freistatt, Lawrence Co., March 27, 1886. I had the pleasure of seeing twelve pure white, beautiful cranes flying low over St. Louis on the afternoon of March 25, 1Sss. Mr. P. L. Ong reported the occurrence of two cranes ( $G$. americana) at Laclede, Linn Co., March 20 and 27, 1889. The last record at hand is March 9, 10 and 15, 1894, from Stotesbury, Vernon Co., made by Mr. T. Surber in his migration report to the Dep't of Agriculture. There is no fall record for Missouri, but T. M. Trippe saw "quite a number" in the fall of 1872 in Decatur Co., Iowa, just across the line of northcentral Missouri. One winged on the Grand Prairie in Dunklin Co. in 1864 was kept alive by Dr. Cook of Cottonplant and after his death by his widow for over thirty years.

\section{Grus Canadensis (Linn.). Little Brown Crane.}

Grus jraterculus. Northern Sandhill Crane.

Geog. Dist.-Aretic and subarctic America. Breeds in the high north along the Aretic coast, and migrates south through western United States to Texas and New Mexico.

A female was shot in Clark Co., Mo., April 10, 1896, and brought to Mr. W. E. Praeger, who has the skin in his collection. It has repeatedly been taken in eastern Nebraska (and Wisconsin), and is regarded as a common migrant in Kansas.

206. Grus mexicana (Müll.). Sandhill Crane.

Grus canadensis (part.). Brown Crane. Grus americana (By Audubon supposed to be young of Whooping Crane).

Geog. Dist.-From central Mexico and Florida to southem Canada. Rare east of the Alleghanies north of Georgia. West to California. Breeds locally throughout its range from Arizona 
to southeastern British Columbia, and formerly east to Florida and Ohio. Winters in the Gulf States and Mexico.

In Missouri formerly a fairly common transient visitant, mainly from the middle to the end of March, sometimes earlier (March 4 and 5, 1882, St. Louis) or later (April 10, 1894, Keokuk). W. E. D. Scott mentions the Sandhill Crane as being a common migrant at Warrensburg, arriving early in April 1874. Prince of Wied on his way up the Missouri River in 1833 makes the following entry in his diary: "April 18, 1833. Below Lexington. A large number of Sandhill Cranes filled the air with their voices; they went in flocks northeastward." Fall records are less frequent; they come from the center of the state, Saline and Howard Counties, October 14 to 25, 1885 and 1890. Audubon saw many Sandhill Cranes October 13, 1843, near the mouth of the Grand River. There is no doubt that only a small percentage of their former numbers survive. Very few notes of the last ten years are to be had, while as late as $1872 \mathrm{~J}$. M. Trippe writes from our northern boundary (Decatur Co., Iowa): "Vast numbers pass over in spring and fall; they bred formerly." On his journey up the Missouri River in 1843 Audubon saw five Sandhill Cranes near the mouth of Nodaway River as late as May 7; and Dr. Hoy met with a pair on the prairie between Utica and Lexington May 18, 1854. He writes: "My brother waved his hat and shouted two or three times, when the male bird commenced, by bowing and hopping in a ludicrous manner,-a series of amusing antics, interluded with brief samples of vocal powers that made ample compensation in strength for any lack of melody."

Suborder Rali. Rails, Gallinules, Coots, etc.

Family Rallidae. Rails, Gallinules, Coots. Subfamily Rallinae. Rails.

*208. Rallus elegans (Aud.). King Rail.

Great Red-breasted Rail. Marsh Hen.

Geog. Dist.-Eastern United States; north to Connecticut, southern Ontario, Minnesota; west to eastern Nebraska and Kansas. Breeds in fresh-water marshes throughout its range. Winters in the southern states.

In Missouri a fairly common summer resident in the marshes 
along the large rivers; arrives from the last of March to the end of April and remains to the latter part of October. Specimens in the collections of Dr. D. T. Kizer of Springfield and Mr. J. D. Kastendieck of Billings were taken in Greene and Christian counties in the Ozark border region and Mr. Philo W. Smith, Jr. of Eureka Springs reports this species as a rare breeder in the White River valley along our southern boundary (1906). Young were seen as early as June 1, 1905, at Mudlake, St. Charles Co.

*212. Rallus virginianus Linn. Virginia Rail.

Little Red-breasted Rail.

Geog. Dist.-From Central America and Cuba to New Brunswick, Ontario and Manitoba; on the Pacific coast to British Columbia. Breeds throughout its range in the United States, but chiefly northward. Winters in the South Atlantic and Gulf States, Mexico and California.

In Missouri the Virginia Rail is a fairly common transient visitant in spring, occurring not only in the marshes of the larger rivers, but in wet places of the Prairie and Ozark border regions. It may be found all through April and early May (earliest date March 31, 1887, St. Louis; latest May 19, Warrensburg). It has been found breeding in Clark Co. by Mr. E. S. Currier. There is no record of its occurrence in fall.

\section{*214. Porzana Carolina (Limn.). Sora. \\ Rallus carolinus. Ortygometra carolina. Common Rail. Ortolan. Car- olina Crake.}

Geog. Dist.-From northern South America and the West Indies to British Provinces (rarely to Greenland); in the West to lat. $55^{\circ}$; in the Mackenzie River region. Breeds chiefly north of lat. $38^{\circ}$, and winters from the South Atlantic and Gulf States southward.

In Missouri a common transient visitant in all parts of the state, the Ozarks not excepted. Some may be found as early as April 1 , but they are most plentiful and generally distributed during the second half of April, and in the north to the middle of May. Fall migration begins early in September and lasts through October (latest November 19, 1893). It has been observed in summer in St. Charles and Howard Co., and nests have been found near Kansas City (ten eggs, Mr. O. C. Sheley, Independence) and in Clark Co. (Mr. E. S. Currier). 


\section{Porzana novmboracensis (Gmel.). Yellow Rail. \\ Rallus noveboracensis. Ortygometra noveboracensis.}

Geog. Dist.--North America to Hudson Bay, chiefly eastern; in the West to Utah, Nevada and California. Nowhere common. No extralimital records except Cuba and Bermuda. Breeds from Connecticut, northern Indiana and Wisconsin northward, and winters in the southern States, often met with on rice fields in Louisiana.

In Missouri an apparently rare or irregular transient visitant chiefly in April. Earliest date of capture, March 27, 1876, Hurter collection. Records are chiefly from the Mississippi bottom north of St. Louis, but there is a specimen in Mr. Chas. W. Tindall's collection taken near his home, Independence, and one in the collection of Dr. G. C. Rinker at Unionville. Mr. E. S. Currier regards them as irregular transients at Keokuk, where Mr. W. E. Praeger found them common April 22, 1888, and April 21, 1889, at Sand Ridge, Clark Co., Mo. In the late and cold spring of $1897 \mathrm{Mr}$. O. Poling found it numerous in May near Quincy. Mr. Chas. K. Worthen thinks that they sometimes breed near Warsaw, Ill., as he has found it occasionally during the breeding season. 'There is no record for' fall migration, but this is not surprising when we consider how difficult it is to flush them or make them fly any distance since they always prefer to escape by running and skulking.

\section{Porzana Jamaicensis (Gmel.). Black Rail.}

Rallus jamaicensis. Little Black Rail.

Geog. Dist.-From the West Indies and Chile to New England and Oregon. Seems to breed locally throughout its range, but easily overlooked on account of its small size and secretive habits. Nowhere common. Winters in Central America.

Taken only once in Missouri (St. Charles Co.), but probably of frequent occurrence in spring and fall, possibly a summer resident, since nests have been found in Illinois and Kansas (nest with 8 eggs near Manhattan, June 1880; nest with 10 eggs, June 19, 1875, Calumet River, Illinois). The earliest date for the vicinity of our state is March 18, 1886, Neosho Falls, Kan., and the latest in fall, October 11, 1885, Iowa City, Ia. Since the above was written I am informed by Dr. G. C. Rinker of Hamilton, Kan., that he took a Black Rail at Unionville, Putnam Co, Mo., and has it in his collection. 


\section{Subfamily Gallinulinac. Gallinules.}

21S. Ionornis martinica (Linn.). Purple Gallinule.

Fulica martinica. Gallinula porphyrio. Porphyrio martinica.

Geog. Dist.-From northern South America, West Indies, Mexico to South Atlantic and Gulf States, irregularly north to Middle, and casually to Northern States and Canada. Winters chiefly south of United States.

In Missouri probably only an accidental visitant, having been taken but twice in the vicinity of St. Louis; April 18, 1877, Hurter collection; and April 22, 1877, near St. Charles in the Blanke collection. (A record from Manhattan, Kan., is dated April 14, 1893, and one from northern Illinois, [April 24, 1900.)

*219. Gallinula galeata (Licht.). Florida Gallinule.

Crex galeata. Gallinula chloropus. Mudhen. Moorhen. Waterhen.

Geog. Dist.-From Brazil and Chile to southern Canada and central California. Breeds throughout its range and winters chiefly south of the United States.

Twenty years ago Florida Gallinules used to be numerous breeders on the lakes and sloughs in the neighborhood of St. Louis. Gradually they became fewer and fewer until now we must class them among the rare birds. There is no record of their breeding in the southeast, and the only one from the west comes from Independence (Tindall, June 1, 1904). In the bottomland from St. Louis northward there are still a few secluded spots, where they can raise a brood, but with the generally established drainage of their favorite waters the only places left to them will be game preserves where neither drainage nor summer shooting is allowed. Fortunately Gallinules have learned to come late, after the first of May, when the hunting season is over and when there is enough plant growth to afford hiding places. Transients are scldom noticed; those breeding north of central Missouri seem to pass over or by us without stopping. The only record for a fall transient is October 3, 1905, St. Louis, a young of the year found alive with broken legs in the street near one of the St. Louis water towers against which it had probably flown in the night. Early in October, 1906, another one, now in the bird cage in Forest Park, was caught in the streets of St. Louis. 


\section{Subfamily Fulicinae. Coots.}

*221. Fulica americana Gmel. American Coot.

Fulica atra. Coot. Mud hen.

Geog. Dist.-From northern South America through West Indies and whole of North America to Canada, rarely to Alaska and Greenland. Breeds from Texas and Louisiana northward and winters from the Southern States southward.

In Missouri the Coot is a very generally distributed and common transient visitant from the middle of March to April 20 and from October 10 to November 25. Also a not very rare summer resident and breeder in suitable localities, not only in the flood plains of the larger rivers, but in the prairie and Ozark regions and reported as breeding at Montgomery City (Parker), Warrensburg (Smithson), Independence (Tindall), Pierce City (Nehrling), White River (Philo Smith Jr., Eureka Springs), Fayette (Kilpatrick).

\section{Order LIMICOLAE. Shore Birds.}

Family Phalaropidae. Phalaropes.

222. Crymophilus fulicarius (Linn.). Red Phalarope.

Tringa fulicaria. Phalaropus fulicarius. Gray Phalarope.

Geog. Dist.-Northern parts of northern hemisphere, breeding within the Arctic regions and coming south in winter chiefly coastwise to the Carolinas on the Atlantic and Cape St. Lucas on the Pacific; rare in the interior as far south as the Ohio Valley.

Has been taken two or three times in the Mississippi River between Missouri and Illinois by Mr. Chas. K. Worthen of Warsaw, Ill. Also recorded from Lawrence, Kan., about 40 miles from our state line, where a young female was taken November 5, 1905. Other records are from Illinois, Indiana, Wisconsin, Minnesota and Wyoming (September 14, 1897).

223. Phalaropus lobatus (Linn.). Northern Phalarope.

Tringa lobata. Lobipes lobatus. Tringa hyperborea. Phalaropus hyperboreus. Lobipes hyperboreus. Red-necked Phalarope. Gray Phalarope (winter).

Geog. Dist.-Northern hemisphere, breeding in America from Labrador and Greenland both in wooded country and on Barren 
Grounds to Alaska. In winter to the tropics, migrating chiefly along the Pacific, less conmonly in the interior and along the Atlantic coast.

A specimen in the Hurter collection was taken October 9, 1878, near St. Louis. One in Mr. J. D. Kastendieck's collection was killed near Billings, and another in Mr. A. Lange's possession was captured by him in Platte Co., Mo., opposite Leavenworth, Kan. Specimens were obtained at Lincoln, Neb., August 23 and September 18, 1904, and May 14, 1905; taken also in Kansas, May 25, 1883.

\section{Steganopus tricolor (Vieill.). Wilson's Phalarope.}

Phalaropus tricolor. Phalaropus lobatus. Phalaropus or Steganopus Wilsoni.

Geog. Dist.-From southern South America to Saskatehewan, chiefly in the interior. Breeds from Wisconsin and northern Nebraska, the mountains of Colorado and the Death Valley northward; formerly in Illinois, Iowa, Kansas and Missouri. Winters south of the United States.

In Missouri this beautiful and graceful bird, formerly common, must now be classed with the rarer transient visitants. It should be looked for in the latter part of April and first of May and in August and September. Earliest date in spring, April 22, 1880, St. Louis, Hurter collection, and in fall, August 5, 1878, St. Louis, Hurter collection. Mr. Currier found it near Keokuk, May 6, 1898. Mr. Tindall at Independence, May 1, 1900. There is a fine specimen in Mr. Kastendieck's collection. Mr. H. Nehrling found it with young in July, 18\$4, in Lawrence Co., and it may still be a local breeder in some parts of the state. In Hayden's Report on the Natural History of the Upper Missouri in 1855, '56 and '57, we read: "Quite abundant during spring montlss along marshy bottoms and lakes of the lower Missouri River."

\section{Family Recurvirostridae. Avocets and Stilts.}

225. Recurvirostra americana Gmel. American Avocet.

Geog. Dist.-From Guatemala and West Indies to lat. 540, rarely as far north as Great Slave Lake; common from Kansas and Nebraska westward; now rare in the eastern United States and acciclental on the Atlantic coast. Breeds locally in most of the western states, but now chiefly in Alberta, Assiniboia and 
Saskatchewan. Winters in southern California, but mainly south of the United States.

In eastern Missouri the Avocet has always been regarded as a rare transient visitant. A female in the Hurter collection taken near St. Louis is dated October 28, 1878. Mr. Praeger saw a mounted specimen which was killed on the bars in the Mississippi near Keokuk previous to 1885 . In western Missouri it seems to be less rare. Mr. Thad Surber met with a flock of one hundred, April 8, 1894, near Stotesbury in Vernon Co., and Mr. A. Lange of Leavenworth, Kan., took some Avocets in Platte Co., Mo.

[226. Нimantopus mexicanus (Müll.). Black-necked Stilt.]

Charadrius mexicanus. Himantopus nigricollis. Recurvirostra himantopus. Stilt. White Snipe (Utah). Lawyer. Long-Shanks.

Geog. Dist.-From northern Brazil and Peru to northern United States, now rare in eastern United States except Florida. Breeding area in United States now restricted to the West from Mexico, southwestern Texas and Colorado to Oregon. Winters from Florida and Louisiana southward through West Indies, Mexico and Central America to Brazil and Peru.

As there are five records of its capture near Omaha, Neb., April 20, 1895, May 6, 1894, May 10, 1893, and October 3 and 9, 1894 , it is very probable that stragglers can be found in western Missouri, if students will look out for them on flooded lands after heavy rains in spring and fall.

Family Scolopacidae. Snipes, Sandpipers, etc.

*228. Philohela iminor (Gmel.). American Woodcock.

Scolopax minor. Rusticola minor. Microptera americana.

Geog. Dist.-Eastern United States and southern Canada from Nova Scotia and New Brunswick to Manitoba; west to the Plains; breeding throughout its range and wintering in the southern states.

In spite of all persecution the Woodcock is still a fairly common summer resident in eastern Missouri; some winter in the Peninsula, but the bulk returns to it in February, to southern Missouri generally early in March and to northern Missouri in the latter part of that month, where they remain till the middle of November. Young birds well on the wing were seen June 2, 1905, in 
St. Charles Co. Though Mr. Nehrling found the Woodcock common in autumn 1884 in Lawrence Co. and mounted specimens are in the collections of Mr. LeBlane at Springfield and $\mathrm{Mr}$. Kastendieck at Billings, the species does not seem to be of frequent occurrence in the western part of the state.

\section{Gallinago delicata. (Ord). Wilson's Snipe.}

Scolopax delicata. Scolopax gallinago. Scolopax ITilsoni. Gallinago Wilsoni. Scolopax Drummondi. Scolopax Douglasii. Am. Snipe. Long-bill. Jack Snipe.

Geog. Dist.-From northern South America through Central America and West Indies north to the Arctic circle. Breeds from northern United States northward and winters from Florida and southern Texas southward.

In Missouri the Snipe is a common transient visitant of general distribution, both east and west, spring and fall, though varying much both in time of presence and in numbers. In some seasons the first Snipes are taken in the neighborhood of St. Louis in the second half of February (February 17, 1897; February 20, 1898; February 24, 1886; February 28, 1904; in others in the first part of March, in some years not before the midlde of March (March 15, 18s8; March 15, 1902; March 13, 1903). The bulk of the species is present from the 15 th to the 20th of March till from the 20th to 25th of April; the last are all gone before the end of the month. In the more northern parts of the state the first appear seldom before the middle of March (March 13, 1900, Keokuk), usually between the 20th and the 25th and remain to the close of April, sometimes into May (May 9, 1896, St. Joseph; May 7, 1894; May 7, 1897; May 12, 1895, Keokuk). In their southward migration in fall they are even more uncertain in time and numbers than in spring. Exceptionally early dates are August 17, 1897, and September 3, 1893, Keokuk, and August 31, 1886 , St. Louis. After the middle of September their appearance may be expected along our northern boundary (September 19, 1902; September 20, 1899, Keokuk). In central Missouri the first are taken in the second week of October, but Snipes are seldom plentiful in Missouri before the middle of October and cease to be so after the first week of November, though some linger into the latter part of the month (November 21, 1897 and 1899; November 24, 1896 and 1900, Keokuk) and exceptionally longer (December 14, 1904, St. Charles Co.) even in northern Missouri. In the most southern part of the state a few may remain in mild 
winters, as they are known to do in Ohio, Indiana and Illinois. The new game protection law of Missouri gives no proteetion to this species, the open season extending over the whole period of its presenee in the state, namely from September 15 to April 30.

\section{[231. Macrorhamphus griseus (Gmel.). Dowitcher.]}

Scolopax grisea. Scolopax noveboracensis. Red-breasted Snipe. Brown Back. Gray Snipe. Gray-back (winter).

Geog. Dist.-Eastern North America, breeding far north; south in winter to Brazil. Irregularly to Alaska, Oregon, Idaho, Nebraska and formerly common in Wiseonsin.

As the two species of this genus were formerly regarded as varieties and were said to be indistinguishable in the winter and immature plumage, not enough attention was paid to them to enable us to say in what proportion they visited the state while Dowitchers were yet plentiful; but since it is known, that the eastern form or species oceur's in the Mississippi Valley along with the western, the claim for a place in our list may yet be established.

232. Macrorhanipuus scolopaceus (Say). Long-billed Dowiteher.

Limosa scolopacea. Macrorhamphus griseus scolopaceus. Red-bellied Snipe. Red-bellied Dowitcher. Greater Long-beak.

Geog. Dist.-Western North Ameriea; breeding in Alaska to the Aretic eoast; migrating through western United States and Mississippi Valley, rarely through Eastern States, to Mexico.

Twenty years ago Dowitehers were fairly, though irregularly, eommon transient visitants in all suitable localities of Missouri. They migrated in flocks, and large numbers were sometimes found in the St. Louis market, chiefly in April. In fall they were still more irregular in their appearance and have been known to oeeur from August to the end of October (October 28, 1873, Hurter eollection). At present they must be classed among the rare birds and, if spring shooting is not abolished, they may be brought to the point of extermination.

233. Micropalama hiniantopus (Bonap.). Stilt Sandpiper.

Tringa himantopus. Tringa Douglasii. Tringa Auduboni.

Geog. Dist.-Eastern North Ameriea; west to the foot of the Rocky Mountains; north to the Arctic eoast. Breeds north of 
the United States and winters in the West Indies, Central and South America.

In Missouri the Stilt Sandpiper, which is said to move rapidly through the United States spring and fall (Audubon), is a rare transient visitant in August and September and very irregularly in spring. (April 30, 1902, Kansas City; September 28, 1878, Hurter collection).

\section{Tringa canutus Limn. Ḱnot.}

Tringa cinerea. Tringa islandica. Tringa rufa. Robin Snipe. Redbreasted Sandpiper. May Bird. Grayback (young). Blue Plover (young).

Geog. Dist.-Chiefiy on the sea coasts; in northern hemisphere in summer; in southern hemisphere in winter. Breeds far north; migrates mainly along the Atlantic coast.

The Knot is probably only an accidental visitant in Missouri. It has been taken in Platte Co., opposite Leavenworth, Kan., by Mr. A. Lange of that eity and another was taken October, 1874, at Brownville, Neb., which is on the Missouri River opposite the northwest eorner of our state; three others were reported from southeastern Nebraska, May 16, 1896, August 27, 1896, and September 30, 1893. Two specimens were shot in the spring at Neosho Falls, Kan., within fifty miles of our western state line. According to Prof. Snow the species was formerly common in Kansas (Birds of Kansas, 1873) and seems to have been met with oftener in the interior generally, especially in the region of the Great Lakes.

235. Arquatella maritima (Brünn.). Purple Sandpiper.

Tringa maritima. Winter Snipe. Rock Snipe.

Geog. Dist.-Northern portions of northern hemisphere. In America chicfly the northeastern portions, breeding in the high north and wintering from Greenland southward along the coast to the Carolinas, casually to the Great Lakes and larger streans in the Mississippi Valley.

The Purple Sandpiper is admitted on the strength of its being mentioned in Dr. P. R. Hoy's list of birds taken in western Missouri in the spring of 1854 .

239. Actodromas maculata (Vieill.). Pectoral Sandpiper.

Tringa maculata. Tringa pectoralis. Jack Snipe. Grass Snipe.

Geog. Dist.-Whole of North America, rare in California. 
Breeds in the Arctic regions, chiefly Alaska; migrates through United States and West Indies to South America as far south as southern Brazil and Chile.

In Missouri a common transient visitant from March 15 to June 6 and through August, September and October to the middle of November (November 5, 1901, November 14, 1896, November 24, 1900, Keokuk, Currier). Mr. Praeger gives it as abundant at Keokuk from March 28 to April 23, and from August 11 to October 21. Mr. Nehrling reported it as very common during the first half of April in Lawrence Co. The species is said to be common at Independence (Tindall) and at Fayette (Kilpatrick) from March 15 to April 10. Records show that some linger through May and even into June; (May 11, 1882, St. Louis; May 14, 1895, May 16, 1898, May 27, 1901, and June 6,1893 , Keokuk).

240. Actodromas fuscicoldis (Vieill.). White-rumped Sandpiper.

Tringa fuscicollis. Tringa schinzii. Tringa bonapartei. Bonaparte's Sandpiper.

Geog. Dist.--Breeding in Aretic regions, chiefly from Hudson Bay to Mackenzic River; it migrates through United States, mainly east of the Rocky Mountains, West Indies and Central America to South Amcrica as far south as Falkland Islands.

In Missouri formerly a fairly common, now a rather rare, transient visitant late in May and early in June, and again early in autumn. Twenty years ago Mr. Nehrling regarded it a common transient visitant in Lawrence Co., and Mr. Kastendieck collected specimens in 1882 at his mill-pond in Christian Co. Mr. E. S. Currier met with a flock of ten at Sand Ridge, Clark Co., May 16, 1898, and again, June 2, 1901, a flock of eight near the mouth of Des Moines River on a sand-bar. His latest date is June 5, 1894, when the first was seen near Keokuk, May 22. Mr. E. S. Woodruff found a flock of about twelve at Jacks Fork of Current River in Shannon Co., May 15, 1907.

\section{Actodromas bairdi Coues. Baird's Sandpiper.}

Tringa bairdii. Bull-peep.

Geog. Dist.-Breeds from Hudson Bay along Arctic coast to Point Barrow and migrates through the interior of North America, rarely along the Atlantic coast, south to Chile and Patagonia. 
In Missouri a fairly common migrant from March till the close of May, and in fall from August till the middle of October, often in company with its nearest relatives, the Pectoral Sandpiper (October 13, 1893, Independence, Tindall; October 14, 1888, Keokuk, Praeger).

\section{Actodronas minutilla (Vieill.). Least Sandpiper.}

Tringa minutilla. Tringa wilsonii. Tringa pusilla. Peep. Mud-peep. Stint.

Geog. Dist. - The whole western hemisphere; breeding from Magdalen Islands and Anticosti to the interior of Alaska; wintering from South Carolina and southern California southward.

In Missouri the Least Sandpiper is a fairly common transient visitant from the middle of April through May to the first of June, and from the middle of August to November, frequenting with other sandpipers and plovers the extensive mud flats of the Mississippi and Missouri Rivers.

243a. Pelidna alpina Sakhalina (Vieill.). Red-backed Sandpiper.

Tringa alpina pacifica. Tringe cinclus. Pelidna pacifica. Red-breast or Red-back (in spring). Lead-back (in fall). Black-bellied Sandpiper. Dunlin. Ox Bird.

Geog. Dist.-North America and Eastern Asia, chiefly coastwise, rare or irregular in the interior. Breeds from Hudson Bay along Arctic coast to northern Alaska. Winters in California, the South Atlantic and Gulf coast and southward.

In Missouri the Rerl-backed Sandpiper is a rare transient visitant, spring and fall. It was first taken in the state by Dr. J. A. Allen opposite Leavenworth, May 1871 (Bull. M. C. Z., vol. 3,1872 ). A female in the Hurter collection was taken near St. Louis, October 7, 1880, and Mr. Praeger took one near Keokuk, October 4, 1885. Dates of specimens taken near Lincoln, Neb., are May 22, August 23, September 4 and 11, 1904, and May 14, 1905; May 16 and 30, 1896; May 22, 1899; Noven-ber 7, 1896; and near Omaha, May 12, 1895.

246. Ereunetes pusillus (Linn.). Semipalmated Sandpiper.

Tringa pusilla. Tringa semipalmata. Ereunetes petrificatus. Sand-peep. Peep.

Geog. Dist.-Eastern North America, west to Utah, breeding from Labrador to Point Barrow and migrating through the 
United States south to the West Indies and northern South America.

In Missouri a common transient visitant in late A pril and May and again in August and through September to October 17. Earliest in fall, August 6, 1887, St. Louis; latest, October 17, 1880, Hurter collection.

\section{Ereunetes occidentalis Lawr. Western Sandpiper.}

Ereunetes pusillus. Ereunetes petrificatus (of western localities).

Geog. Dist.-Western North America, breeding chiefly in Alaska and migrating through western United States, mostly along Pacific coast, to Central and South America. Casually eastward through the interior to the Atlantic coast in company with the Semipalmated Sandpiper.

Has been taken a few times in spring on sandbars in the Mississippi River by Mr. Chas. K. Worthen of Warsaw, Ill. In the spring plumage the Western is easily distinguished from the Semipalmated Sandpiper by its bright chestnut on head, back and rump.

\section{Calidris arevaria (Linn.). Sanderling.}

Tringa arenaria. Calidris calidris. Calidris rubidus. Beach Bird.

Geog. Dist.-Almost cosmopolitan; breeding in arctic and subarctic regions and in America, migrating through United States, both coastwise and through interior; wintering from California and southern Texas to Chile and Patagonia.

In Missouri the Sanderlings were formerly fairly common transient visitants from the latter part of August to October. They were found in small flocks on the extensive sand bars in the Mississippi River, frequenting the same place for weeks, together with other sandpipers and plovers. In spring they appeared to be more in a hurry, never remaining long in one place. Like all waders their numbers have greatly decreased during the last twenty years and the species seems never to have been as common westward as in the eastern part of the state.

249. Limosa fedoa (Linn.). Marbled Godwit.

Scolopax fedoa. Limosa foeda. Marlin. Dough Bird.

Geog. Dist.-North America to southern Canada; rare on the Atlantic coast. Breeding formerly from Iowa, Wisconsin and eastern North Dakota northward, now restricted mainly 
to Alberta, Assiniboia and Manitoba, becoming scarce everywhere. In winter to the Gulf coast, California, Mexico and parts of Central America and the West Indies.

In Missouri Marbled Godwits could formerly be called fairly common transient visitants in April and September; they are now rare.

\section{Limosa haemastica (Limn.). Hudsonian Godwit.}

Scolopax haemastica. Limosa hudsonica. Black-tailed or Ring-tailed Godwit or Marlin.

Geog. Dist.-From southern South America to Arctic regions, breeding in the high north and wandering through the eastern United States to South America. Rare on the Atlantic coast.

In Missouri a rather rare transient visitant in April and October. A male in the Hurter collection was taken in St. Louis Co., April 19, 1872, and two in the collection of the Cuivre Club were killed on their grounds in St. Charles Co.

254. Totanus melanoleucus (Gmel.). Greater Yellow-legs.

Scolopax melanoleuca. Gambetia melanoleuca. Scolopax vociferus. Totanus vociferus. Tell-tale. Stone Snipe. Greater Yellowshanks.

Geog. Dist.-Nearly the whole of America; breeding formerly from Iowa, Illinois and Wisconsin northward, at present from northern Nebraska north to the Mackenzie Rivel and Sitka. In winter from southern California and the Gulf States south to Argentina and Chile.

In Missouri Greater Yellow-legs are still fairly common and generally distributed transient visitants, especially in spring, less so in fall. The first appear from the south during the last week of March, seldom earlier (March 9, 1903, Kansas City, Bryant). They become more general during the second week of April and are most plentiful in the second half of that month. In ordinary seasons they disappear in the first half of May, but in cool Mays some have been known to stay toward the end of May and even into June (June 5, 1894, Keokuk, Currier). In fall migration their appearance is more irregular. Near Keokuk they have been found as early as August 28, 1899, and as late as November 9, 1895, also at Independence (Tindall) November 7,1892 , but they are most likely to be present about the middle of October. 
255. Totanus flavipes (Gmel.). Yellow-legs.

Scolopax favipes. Gambetta flavipes. Lesser Tell-tale or Yellowshanks.

Geog. Dist.-Nearly the whole of America; breeding from northern United States to Arctic ocean, chiefly in the interior; migrating south in winter to southern South America. Much rarer west of the Rocky Mountains.

In Missouri the Yellow-legs is a common transient visitant occurring sometimes in very large flocks from the middle of March to the middle of May, and in smaller numbers from August 2 to the middle of October.

256. Helonromas solitarius (Wils.). Solitary Sandpiper.

Tringa solitaria. Totanus solitarius. Rhyacophilus solitarius. Totanus chloropygius. Wood Tattler. Tip-up.

Geog. Dist.-Eastern North America, west to Utah, Wyoming, British Columbia and Alaska. Breeds locally within the northern and western United States, but chiefly northward through the Northwest Provinces to latitude $64^{\circ}$. Winters in South America.

In Missouri a common transient visitant, never in flocks, but scattered along water-courses and even small pools throughout the state from April 15 to May 25, and from August 1 to October 10, chiefly from August 20 to September 25. Latest in spring, May 27, 1894, Keokuk; and in fall, October 9, 1902, Jasper Co.

258. Srmphemia semipamata (Gmel.). Willet.

Scolopax semipalmata. Totanus semipalmatus. Semipalmated Tattler.

Geog. Dist.-Eastern North America, north to British Provinces, west to the Mississippi. Breeds from Florida to New Jersey, rarely northward. South in winter to West Indies and South America.

Formerly not separated from the western Willet from which it differs very little. Records for Willets do not show which of the two subspecies is meant, but both may occur in Missouri, the one in the eastern, the other in the western part.

258a. Symphemia semipalinata inornata Brewster. Westem Willet.

Geog. Dist.-Western North America, east to the Mississippi Valley, north to latitude $56^{\circ}$. Breeds from Texas and Louisiana northward and winters in Mexico. 
While in the breeding plumage it may be comparatively easy to tell the two subspecies apart, in the plain gray and white dress which they wear in migration, they are said to be clistinguishable only by size, but even this difference is said to be not absolutely reliable. All Willets taken in Missouri should therefore be subjected to a close serutiny to establish their identity as subspecies. In Missouri Willets were formerly fairly common transient visitants in late April and early May, and again in September. That they occurred even in large flocks is proved by Audubon, who writes in his Journal that he met with a large flock of Willets near St. Joseph, Mo., May 5, 1843. At present they are considered rare throughout the state. An exeeptionally late date is given by Mr. Currier of Keokuk, namely October 27, 1896.

\section{*261. Bartramia longlCauda (Bechst.). Bartramian Sand- piper.}

Tringa longicauda. Tringa bartramia. Totanus bartramius. Actiturus bartramius. Bartram's Tattler. Field Plover. Upland Plover. Grass Plover.

Geog. Dist.-Eastem North America, west to Utah and Oregon, north to Nova Seotia and Alaska. Breeds throughout most of North American range, but chiefly in the prairie and plains region with its breeding center in western Manitoba and eastern Assiniboia. Winters in South America, as far south as Brazil and Peru.

In Missouri Field Plover's used to be fairly common summer residents in the Ozark border and Prairie regions; in some localities a few may still be found nesting (Appleton City, Prior, 1906), but with an open scason till the first of May there is little hope for them. In migration, too, their numbers have been greatly reduced, not one-tenth of the transient visitants of twenty years ago being left. In the southern part of the state the first Field Plovers make their appearance in the latter part of March, in northern Missouri seldom before the middle of April. Transients are mostly gone by the first of May, but begin to reappear in family groups the midclle of July and continue to be present through August and nearly to the end of September.

262. Tringites subruficollis (Vieill.). Buff-breasted Sandpiper.

Tringa rujescens. Tryngites rufescens. Tringa subruficollis.

Geog. Dist.-Common on their breeding-grounds along the Arctic coast and on the Barren Grounds from Anderson River 
to Point Barrow, and breeding scatteringly in other parts of the north from Ontario, Minnesota and British Columbia; it is strangely scarce in the United States in migration, except perhaps on the coast prairie of western Louisiana and Texas, where it is found in dense flocks in spring. It is not found in California and very rarely on the Atlantic coast. In winter it goes to South America as far as Uruguay and Peru; frequently found in Europe and Cuba.

On September 15, 1901, Mr. Chas. W. Tindall killed nine Buff-breasted Sandpipers on a sandbar in the Missouri River near Independence. Mr. Chas. K. Worthen of Warsaw, Ill., once took a small flock of this species on a sandbar in the Mississippi River. There are quite a number of fall records from the neighborhood of Chicago, and from southeastern Nebraska, among them two of recent date, September 11, and 18, 1904, Lincoln, Neb.; but spring records are few, through G. S. Agersborg states (Auk vol. 2, p. 286), that he found the Buff-breasted Sandpiper in southeastern South Dakota in abundance in spring, "when it arrives in large flocks. Only very few are seen on the retum passage."

*263. Actitis macularia (Linn.). Spotted Sandpiper.

Tringa macularia. Totanus macularius. Tringoides macularius. Peetweet. Sand-lark. Tip-up. Teeter-tail. Common Sandpiper.

Geog. Dist.-Whole of North, Middle and South America, except Greenland. Breeds throughout the United States and almost to the Aretic coast. Winters south of the United States, going as far south as southern Brazil.

In Missouri a fairly common summer resident along the large rivers from April 15 to October 20, and a common transient visitant in spring on all streams, ponds and lakes, and in July, August and September numerous on the sandbars of the larger rivers.

264. Numenius longraostris Wils. Long-billed Curlew. Sickle-bill.

Geog. Dist.-Formerly an inhabitant of the whole United States, breeding from Texas northward as well as in the South Atlantic States and locally in the Mississippi Valley north to Wisconsin and Minnesota; now their breeding range is restricted to the western and northwestern states, east to western Kansas 
and western Nebraska, north through Assiniboia and Alberta into British Columbia. In winter to California, the Gulf coast and south to some parts of the West Indies and Central America.

In Missouri formerly a fairly common transient visitant early in April and from August to October (latest record, October 15, 1905, Jasper Co., Philo. W. Smith, Jr.), now rare like other waders of large size.

[265. Numenius hudsonicus Lath. Hudsonian Curlew.]

Scolopax borealis. Numenius borealis. Numenius intermedius. Jack Curlew. Short-billed Curlew.

Geog. Dist.-Whole western hemisphere; breeding in the far North, the exact localities not well known, and migrating through United States, chiefly coastwise; wintering from the Gulf states to Patagonia.

In Missouri probably a rare transient visitant about the middle of April and early in October. Apt to be confounded with the Eskimo Curlew, and the large females with the Longbilled Curlew. It is recorded from different points in eastern Nebraska, and according to Agersborg (Auk vol. 2, p. 287) used to be a common migrant in southeastern South Dakota.

266. Numenius borealis (Forst.). Eskimo Curlew.

Scolopax borealis. Dough-bird. Esquimaux Curlew.

Geog. Dist.-Eastern North America; breeding on the Barren Grounds to the southward of Fort Anderson and along the coasts of Behring Sea and Kotzebue Sound. Spring migration chiefly through the interior, generally with Golden Plovers, formerly very common on the plains, now said to go by way of thinly settled parts of western Nebraska and western Kansas. In autum migration formerly common in New England, now flying from Nova Scotia south over the ocean. In winter south throughout South Ameriea.

In Missouri a now rare transient visitant in spring, formerly very common in westem Missouri late in March and throughout April. Mr. Thad. Surber reports seeing a flock of one hundred in Vernon Co., April 16, 1894. Mr. W. G. Savage met with a flock of ten in Jasper Co., May 1, 1902. 
Family Charadrildae. Plovers.

270. Squatarola squatarola (Linn.). Black-bellied Plover.

Tringa squatarola. Squatarola helvetica. Charadrius helveticus. Charadrius apricarius. Beetle-head. Bull-head. Ox-eye.

Geog. Dist.- Nearly cosmopolitan, but chiefly in the northern hemisphere. In America breeding from Hudson Bay along Arctic coast to Alaska and migrating through United States both coastwise and in the interior, to the West Indies, Columbia and Brazil.

In Missouri a rather rare, formerly irregularly common, transient visitant from the middle of April to the middle of May, and in fall to the end of October. Latest record, November 5, 1889, when Mr. Chas. W. Tindall killed one at Independenec.

272. Charadrius dominicus Müll. American Golden Plover.

Charadrius pluvialis. Charadrius virginicus. Charadrius fulvus var. virginicus. Charadrius marmoratus. Green Plover. Field Plover. Bull-head.

Geog. Dist.-Western hemisphere except coast of Behring Sea. Breeds in Aretic regions from Parry Islands to Norton Sound. Migrates through United States, chiefly the interior, in spring, and along the Atlantic coast in fall; very rare in California. In winter to South America as far south as Patagonia.

In Missouri a common transient visitant from latter part of March to nearly the end of April, and rarely in fall. Formerly in very large flocks about the middle of April on the marshes and fields of northern Missouri, where it still occurs, but in much smaller numbers. The new law of 1905 , which forbids spring shooting of plovers in Missouri, will probably be instrumental in increasing plovers of all kinds. Earliest date in spring, March 23, 1872, St. Louis (Hurter collection); latest April 30, 1892, Keokuk (Currier). Fall records are from Keokuk (Currier) October 19, 1902, October 29, 1893 and November 9, 1895; from Independence, November 8, 1892, when Mr. Chas. W. Tindall killed one on a sand bar in the Missouri River.

*273. Oxyechus vociferus (Linn.). Killdeer.

Charadrius vociferus. Aegialites vociferus. Acgialitis vocifera. Killdee Plover.

Geog. Dist.-United States, Mexico and southern Canada, 
breeding throughout its range, wintering from California and the Gulf States southward to northern South America.

In Missouri it may still be called a common transient visitant spring and fall, though it is by no means as abundant as formerly, when it was also well known as a summer resident, not only in the prairie region of the north and west, but also in the Ozark border region and even in the valleys of the Ozarks themselves. A few may still breed in the state, as it is reported to do so at Appleton City by Mr. C. IV. Prier, 1906. Killdeers are among the first migrants to return to us in earliest spring. The first reach Missouri during the latter part of February (February 17, 1898, St. Louis; February 18, 1902, Jasper Co.; February 26, 1904, St. Charles Co.; February 28, 1904, Independence; February 28,1893 , Keokuk). The bulk of transients is with us from the middle of March to the middle of April, and in fall from September 1 to the middle of November. Exceptionally late dates are November 17, 1896, Keokuk: November 26, 1905, Jasper Co. (Philo. Smith); and December 18, 1887, St. Louis.

274. Aegialitis semipalinata Bonap. Semipalmated Plover.

Tringa hiaticula Wils. Charadrius hiaticula Ord. Charadrius semipalmatus. Semipalmated Ring Plover. Ring Plover. Ring-neck.

Geog. Dist.-Aretic and subarctic America from Ungava Bay to Norton Sound, rarely south to Ontario and Manitoba. Migrates through United States and winters from Louisiana and Texas to Brazil, Peru and Galapagos Islands.

In Missouri a fairly common transient visitant from April 20 to May 20, and in fall from August 20 to September 25 in scattered flocks on the mud-flats of our larger rivers together with other plovers and sandpipers.

277a. Aegialitis meloda Circuncincta Ridgw. Belted Piping Plover.

Lately and apparently unnecessarily separated from Aegialitis meloda, the Piping Plover of the Atlantic States, Charadrius hiaticula var. Wils., Charadrius melodus of Ord., Aud. etc.

Geog. Dist.-Mississippi Valley, Manitoba and Assiniboia, west to Wyoming. Breeding formerly from Illinois, Indiana and southern Wisconsin northward, now from northern Nebraska. Also found on the Magdalen and Sable Islands. Winters from the Gulf coast southward. 
In Missouri now a rather rare transient visitant about May 1, and more commonly in August and September with other waders on the mud-flats and sand bars of the larger rivers.

Subfamily Arenarïnae. Turnstones.

283. Arenaria norinella (Linn.). Ruddy Turnstone.

Tringa interpres. Strepsiles interpres. Calico-back.

Geog. Dist.-Breeding in arctic America from Mackenzie River eastward; in migration southward through the United States, coastwise and by way of Great Lakes and larger rivers to South America as far south as Patagonia and Falkland Islands.

In Missouri a transient visitant on the sand bars of the Mississippi River from the middle of August to the middle of September. Occurs probably also in spring, as it has been taken on the Missouri River near Omaha in May and on the Mississippi at Burlington, May 21, 1892. A male was taken on the Kansas River near Topeka, Kan., August 16, 1898, and a single specimen in winter plumage was observed on a sandbar near Cairo, Ill., by Mr. E. W. Nelson, August 30, 1875.

Order GaldinaE. Callinaceous Birds.

Suborder Plasiani. Pheasants, Grouse, Partridges, Quails, etc.

Family Tetraonidae. Grouse, Partridges.

Subfamily Perdicinae. Partridges.

*289. Colinus virginianus (Linn.). Bob-white.

Tetrao virginianus. Perdix virginiana. Ortyx virginianus. Quail (in New England). Partridge (Middle and Southern States).

Geog. Dist.-Eastern United States, north to southern Maine, southern Ontario and Minn esota, west to South Dakota, Nebraska, Kansas, Oklahoma and eastern Texas. Lately introduced into New Mexico, Colorado, Utah, Idaho, California, Oregon and Washington. Breeds throughout its range and is non-migratory, able to withstand the rigors of the northern states, where with sufficient protection in winter it would become half-domesticated and very plentiful. 
According to our new game law of 1905 November and December are the only months in which Bob-whites may lawfully be killed in Missouri, and it is to be hoped that this lovely bird may regain its former abundance. Feeding the whole year round on insects, weedseeds, and waste grain it is one of the most beneficial birds on the farm and should, therefore, receive all the protection the farmer can give. Though generally considered non-migratory, local migrations from exposed to more sheltered places have often been noticed, and according to Dr. A. F. Eimbeck of New Haven, Franklin Co., a regular north and south migration is a fact well known to people living along the shores of the Missouri River, where Quails are scen toward evening flying across the river, southward in September, northward in April. The river being over half a mile wide some of the birds become exhausted and fall into the water where they are picked up by the people along the shore.

\section{Subfamily Tetraoninae. Grouse.}

*300. Bonasa umbellus (Limn.). Ruffed Grouse.

Tetrao umbellus. Pheasant. Partridge (in northern states).

Geog. Dist.-Eastern United States and southern Canada, south along the Alleghanies to Georgia and eastern Tennessee; sparingly through Ohio, Indiana and Illinois to Missouri (northern Arkansas); west to eastern Nebraska and Minnesota. Non-migratory.

Until twenty years ago the Ruffed Grouse, here called Pheasant, was numerous in most wooded parts of Missouri. Early travelers mention it. Audubon killed a pair at the mouth of Grand River, April 30, 1813, and Dr. Hoy has it in his list of birds found above Boonville in early summer, 1854 . In 1872 Trippe found it an abundant brecder in Decatur Co., Ia., just across our northern state boundary, and Mr. Nehrling saw a specimen killed in 1883 near Pierce City in the Ozark border region of southwest Missouri. Dr. Eimbeck and his brother, who has a very fine mounted male in his collection, say it was common near New Haven until about 1886. About that time Mr. Hurter received a set of eggs from Pevely, Jefferson Co. Mr. W. F. Rasmus born in 1838 near Marthasville, Warren Co., writes that in his youth pheasants were plentiful near his home as well as near Herman and Wash- 
ington, where he lived later for a while. In 1888 Professor Kilpatrick reported from Fayette, Howard Co., "formerly plenty, now scarce." Mr. F. C. Pellet of Salem stated recently that pheasants were once found in Dent Co., but are not found there now. Mr. W. G. Savage writes me that fifteen years ago pheasants were considered common in Shannon Co. and that some still occur there, though rarely. One was shot near Monteer in the winter of $1905-96$. Mr. B. T. Gault met with Ruffed Grouse in two places near Edgehill in Reynolds Co. in June 1894. Mr. E. S. Currier found a nest with eggs on hilly ground in Lee Co., Ia., just across the Des Moines River from Clark Co., Mo., about ten years ago.

Although Ruffed Grouse must at present be regarded as rare in Missouri, there are some very recent records which prove that they are not entirely exterminated. Dr. Williams of Flat River knows where to find pheasants along the Big River in St. Francois Co. and Dr. W. Mills and Mr. Jul. Volkman of Webster Groves have lately located small colonies along the Meramec River in St. Louis Co. and on the bluffs of the Missouri River in Franklin Co. Mr. Philo Smith found pheasants only a few years ago in the hills back of Herman in Gasconade Co. The new game law (section 10) prohibits their capture or killing until December 1, 1910, when it is expected they will again be plentiful enough to permit an open season of one month in late fall or early winter. While they formerly inhabited not only the hilly part of the state, but also the slopes along the then wooded river bottoms of northern Missouri, they are now restricted to the bluff regions of the larger rivers and, to a less extent, to ravines and hillsides along some of the smaller streams, but are never found on the wide ridges of the Ozarks themselves, where conclitions do not seem to suit them. Some think the reason why Ruffed Grouse are not more plentiful in the Ozarks and why they have entirely disappeared from localities where they were not much molested by man, is to be found in the terrible increase and spread of the chigger (Trombidium), which is said to kill the young grouse. That the chigger, carried from place to place by pasturing animals, is steadily increasing and alarmingly spreading to regions not infested before, is a wellknown fact nearly throughout Missouri and, since enemies may determine the breeding range of an animal as well as food and other conditions, I give it as a not impossible theory. Another explanation of their disappearance from the forests of the Ozarks 
may be found in the annual burning over of the floor of these forests in the erroneous opinion the grazing-ground is thereby improved. As this custom has been followed for fifty years, it has succeeded in extirpating a large number of plants, some of which may formerly have been helpful or needed in making the region a desirable abode for the Ruffed Grouse.

*305. Tympanuchus americanus (Reich.). Prairie Hen.

Tetrao cupido. Cupidonia cupido. Pinnated Grouse. Prairie Chicken.

Geog. Dist.-Prairies of the Mississippi Valley from Louisiana and Texas to Manitoba, now rare east of the Mississippi River west through eastern parts of the Dakotas, Nebraska and Kansas with a tendency to spread with deforestation and the settlement of the country, but disappearing when the population becomes dense.

That the Prairie Hen was once a common resident in the prairic region of Missouri, there is anple proof, but as long ago as $18 S 5$ reports came from observers in the state with that lamentable annotation so often met with in recent bird list "Once common, now rare." With the increase of population and prosperity the number of hunters increased wonderfully during the last decade, and when the new game law of 1905 was framed, the danger of total extinction of the Prairie Hen seemed imminent, but instead of following the example of other states prohibiting all killing for a number of years, the legislature made an open season from November 15 to December 15. In a state which issues over 65,000 hunters licenses one month's open season undoubtedly suffices to prevent any considerable increase of the small remnants left. But even with the best protection laws the Prairie Chicken, such an easy mark for every boy hunter-and every Missouri boy in city or on farm is a hunter now-a-days-, has no prospect of ever becoming numerous again except on well-guarded preserves, where they may easily become semi-domesticated. Though as a rule non-migratory the Prairie Hen of northern Iowa and Minnesota has been known to migrate (some say the females only) southward into and through western Missouri in November and December, returning northward in March. Large flocks of such transients or winter visitants were noticed formerly, but their numbers seem to be too much reduced everywhere to notice such a movement at the present time. 
307. Tympanuchus pallidicinctus Ridgw. Lesser Prairie Hen.

Geog. Dist.-Eastern edge of the plains from Kansas south to western Texas. A specimen of this smaller, paler-colored species in the Hurter collection is said to come from southwestern Missouri.

In the Nuttall Bulletin, vol. 2, p. 52, Geo. N. Lawrence writes: "In the latter part of January 1877 I found in Fulton Market (New York) about thirty specimens of this form. *** I ascertained that they came from Pierce City, southwestern Missouri. * * * I lately learned from a large dealer that they had been quite abundant in market, all coming from Southern Missouri."

Family Phasianidae. Pheasants and Turkeys.

Phasianus colchicus Linn. English Pheasant.

Geog. Dist.-Eurasia from Black Sea to Mongolia; south to Persia. Naturalized in Britain and other countries of western and central Europe.

Phasianus torquatus Gmel. Ring-neckel Pheasant.

Geog. Dist.-Southern Siberia, Corea and northeastern China.

Several apparently unsuccessful attempts to introduce Pheasants into Missouri have been made. Major Geo. H. McCann of Springfield, Mo., president of the St. Louis Park and Agricultural Co., and the best informed man on all endeavors of stocking our state with game, was kind enough to write to me under date of June 12, 1907, the following interesting account: "The St. Louis Park and Agricultural Co. has liberated something over 400 birds about equally divided of English and Ring-necked Mongolian Pheasants. They were liberated in Taney Co. on our preserve. We also raised some 32 birds by the Game-keeper's wife and several covies were raised on and about the preserve, but they leave after the first frost in fall when leaves begin to drop. They go-where I know not. I don't believe we have a pair of birds on the preserve. I have inquired for miles around the preserve, they have seen them, but they left. I have labored with them for the past ten years to try and help stock our state, but feel I have made complete failure. I can breed and raise, but when turned loose after a few days they are gone. Springfield, Greene Co., organ- 
ized a elub of some ninety members a few years ago, leased several thousand acres, raised and liberated some 600 birds. For a year we felt success, but as with the St. L. P. \& Agr. Co., it proved failure and I am unable to locate a bird in Greene Co. Some five or six thousand dollars has been spent on those birds. I sent several pairs to north Missouri with like results."

*310. Meleagris gallopavo silvestris (Vieill.). Wild Turkey. Meleagris galloparo. Meleagris galloparo fera.

Geog. Dist.-Formerly entirc eastern United States from Florida to Maine, Ontario and Minnesota; west to Kansas and Nebraska; but at present extinct or at the point of extinction in most states except in the southerm Alleghanies, the Ozarks and heavily timbered bottoms of sonthern rivers. Non-migratory.

In Missouri Wild Turkeys oceurred formerly in all parts of the state, along the densely wooded liver bottoms of the prairie region, in the flood plains of the Mississippi and Missouri Rivers, in the swamps of the southeast and throughout the Ozarks. All the early traveler's speak of the abundance of the Vild Turkeys. Audubon met with them along the Missouri River to the northwest comer of the state (May 6, 1813), and on his way back he speaks of their abundance, October 14, 18t3, between Brunswick and Glasgow. When visiting the Grand River valley near Chillicothe, Livingston Co., Dr. Hoy makes the following note: "Skinned a fine ohl gobbler shot by a friend; wild turkeys are plenty in this vicinity." Across the boundary of north central Missouri, Trippe writes from Decatur Co., Ia., in 1872: "Not uncommon, but shy and vigilant." But as early as 1888 Mr. Lientz reports from Fayette, Howard Co., "Formerly plenty, now scarce." At present (1906) Wild Turkeys are all gone from northern Missouri, but are still found in small numbers in most parts of the Ozarks and in the swamps of the southeast. According to Dr. W. Mills of Webster Groves a few still breed in St. Louis and Franklin Co's. and the species may hold its own for a while yet, though with two months of open season (November and December), which the new (1905) law allows, this will be a difficult matter. 


\section{Order COLUMBAE. Pigeons.}

Family Columbidae. Pigeons.

\section{Ectopistes migratorius (Linn.). Passenger Pigeon. \\ Columba migratoria. Ectropistes macrura. Wild Pigeon.}

Geog. Dist.-Formerly eastern North America to Hudson Bay, west to Great Plains and straggling to Wyoming, Nevada and Washington, breeding from latitude $32^{\circ}$ in Mississippi to latitude $65^{\circ}$ in Mackenize. In later years so extremely rare that their occurrence anywhere may be regarded as casual, unless it be some unsettled parts along the northern border of the United States or in Canada.

Our new game law does not protect the Wild Pigeon at all, considering it extinct in the state of Missouri, though once in a while we find the capture of a few of them reported in the newspapers. That they were formerly abundant in Missouri is attested by the early travelers and explorers and is well known to all the old inhabitants. Available records are the following:

1833, April 21. Prince of Wied killed some above the mouth of the Kaw River.

1843, May 6. Audubon killed one or two north of the present site of St. Joseph.

1855, '56 and '57. F. V. Hayden says in his report: "Quite abundant on the lower Missouri River.'

1872. Large flocks were observed by Dr. A. F. Eimbeck at New Haven, and his brother, Charles L. Eimbeck, who has two fine specimens in his collection of mounted birds.

1874, April 6. W. E. D. Scott saw a flock of seven at Warrensburg.

1878. Last seen at Fayette by Prof. Kilpatrick (Reported in 1885).

1880, September 29. Mr. J. D. Kastendieck took his last Wild Pigeon at Billings, but saw some several years afterward.

1882, February 5 and 6 . Several large flocks were seen going north by the writer at St. Louis.

1883. Last year common (in the fall) at Keokuk (Currier).

1884, September 9 and 21. Seen at Mt. Carmel, by Mrs. Musick. 
1885, April 18, September 27 (twenty), September 28 (fifty) and the last on September 30 at Mt. Carmel.

1885, September 19. Last seen at St. Louis by the writer.

1888, October 31. Mr. Jasper Blines of Alexandria, Clark Co., Mo., writes in Forest and Stream, vol. 31, p. 343: "During the whole year I have seen but few passenger pigeons. They were in former years very numerous here and could be seen in flocks composed of millions of birds every spring and fall."

1893. Last shipment of Wild Pigeons received at St. Louis by N. W. Judy \& Co., the game dealers, who handled more dead and live pigeons than any other firm in the country, and who had their netters employed all the year around, tracing the pigeons to Michigan and Wisconsin in spring and to the Indian Territory and the south in winter. Silvan Springs, Ark., from where the last shipment was received according to Judy's letter to Mr. R. Deane (Auk, vol. 12, p. 298), is only twenty-five miles south of the southwest corner of the state.

1894, April 15. Mr. E. S. Currier sees ten pigeons at Keokuk, his first since 1888 .

1896, May 19. The same sees one among doves, and again one October 18 of the same year.

1896, September 17. Mr. W. Praeger shoots a male near Kieokuk.

1896, December 17. Out of a flock of fifty near Attic, Oregon Co., Mo., Mr. Chas. U. Holden, Jr., kills a pair and sends them in the flesh to Mr. R. Deane of Chicago (Auk vol. 14, p. 317).

1897, August 17. A flock of 75-100 is seen twenty-five miles west of our state line in Johnson Co., Neb.

1902, September 26. Last seen at New Haven by Dr. Eimbeck.

*316. Zenaidura macroura (Limn.). Mourning Dove.

Columba macroura. Columba carolinensis. Zenaidura carolinensis. Carolina Dove.

Geog. Dist.-Breeds from Mexico and Cuba throughout the United States to Quebec, Manitoba and British Columbia and winters from about lat. $40^{\circ}$ southward to the West Indies and Panama.

In Missouri the Dove still remains a common summer resident in spite of almost constant persecution, not only in the prairie and horder regions, but on all cultivated ground throughout the 
Ozarks and the southeast. The first spring arrivals appear at very irregular times, seldom before the mildle of March, most frequently in the sccond half of that month; about once in four years the first Doves are not seen before some day in the first half of April, then soon followed by the bulk, which is to be expeeted between April 10 and 25, when they become generally distributed and begin nesting. Small troops may be seen flying northwarl as late as early May. Where not molested they lose much of their timidity and build nests in elose proximity to human habitations. From July to October, though not forming real flocks, Doves are found in large aggregations on the wheat stubble and in corn-fiekls, gleaning the waste grain and ripening grass and weed seeds. After the middle of October they become scarce, but small numbers continue in northern Missouri into, and sometimes through. November, and in southern Missouri through December. As the law sanctions their destruction till the first of January, very few get a chance to prove their endurance of our more severe winter weather of January and February, when snow and sleet drive them to the farmyard for food and shelter and place them at the mercy of the farmer.

Order RAPTORES. Birds of Prey.

Suborder Sarcorhamphi. American Vultures.

Family Cathartidae. American Vultures.

*325. Cathartes aura (Linn.). Turkey Vulture.

Vultur aura. Rhinogryphus aura. Turkey Buzzard. Red-headed Vulture.

Geog. Dist.-From Patagonia and the Falkland Islands to Assiniboia in the interior, to British Columbia on the Pacific and to Sandy Hook on the Atlantic side, rarely to New England and the British Provinces. Winters from southern California, Ohio River and Chesapeake Bay southward.

The Turkey Vulture or Buzzard, as it is commonly called, is the only one of all our larger birds which has not diminished in number's during the past twenty-five years. It is also one of the few birds that can be seen in any of the 114 counties of Missouri on any clay during six months of the year from April to October. It can hardly be called a permanent resident, not even in the most southern part of the state. Some think 
that a species ean be said to winter with us, when we see an individual in every one of the winter months, but this is not correct. Though frost may oceur in Missouri on any day from the middle of October to the middle of April, our really severe winter weather comes usually only between the middle of January and the micldle of February. Moderately cold weather with frequent mild, and even warm spells may prevail through December and part of January and induce hardy birds to remain with us, but a prolonged period of intensely cold, even zero weather is likely to set in as late as the fourth week of January and last uninterruptedly until the middle of February, fully thrce weeks, when suddenly the weather may turn warm, obliterate all traces of ice and snow within one week and make it possible for the vanguard of migrants to invade the state beforc the end of the month. Among the first to put in an appearance after the withdrawal of severe weather are a few forerunners of this species, but records for February are not many. Exceptionally early dates are for St. Louis, February 10, 1888, and for Keokuk, February 17, 1897; for Mt. Carmel, February 18, 1886. The majority of Turkey Buzzards return in Narch, filling up their ranks very slowly and some of their old haunts are not reached before the first half of April. Troops of migrating Buzzards are seen late in March and early in April and again in the first half of October. After the midelle of that month the species becomes scarce, but cloes not entirely lisappear from the state for some weeks yet and lasts have been reported by different observers all the way from October 16, 1904, Kansas City, to December 14 and January 18 at Nontgomery City, though mainly in November. Whether Turkey Vultures have increased - since the white man has settled the country, is difficult to say, but it is remarkable that Audubon does not mention them among the birds observed on his way up the Missouri River in April 1843, while Dr. Hoy found them "nesting in eliffs all along the river" in April 185t. For reasons only known to the solons of Jefferson City our latest game law, that of 1907, has placed the Buzzard into section 7 together with the English Sparrow, Chicken Hawk, Blackbird and Crow among the birds "not protected by this act."

*326. Catharista urubu (Vieill.). Black Vulture.

Vultur atratus. Catharista atrata. Cathartes atratus. Vultur iota. Carrion Crow.

Geog. Dist. - South Atlantic and Gulf States to western Texas, 
north to North Carolina, and in the Mississippi Valley to the mouth of the Ohio; casually to the northern states and Canada; south through the West Indies, Mexico, Central America and in South America to lat. $41^{\circ}$.

In Missouri a regular, though not numerous, summer resident in the alluvial counties of the southeast, where it is said to make its nests on cypress stumps in the overflow in similar situations as the Canada Goose. Also seen by the writer along the White River in southwestern Missouri in Stone Co. in June 1905, and in Taney Co., May 1906, in company with Turkey Vultures. Mr. H. Nehrling reported it as having occurred twice in Lawrence Co. Mr. E. S. Woodruff identified one April 29, 1907, in Shannon Co.

Suborder Falcones. Falcons, Hawks, Buzzards, Eagles, Kites, etc.

Family Falconidae. Falcons, Hawks, Eagles.

Subfamily Accipitrinae. Kites, Buzzards, Hawks, Eagles.

*327. Elanoides forficatus (Limn.). Swallow-tailed Kite.

Falco forficatus. Falco furcatus. Nauclerus forficatus. Nauclerus furcatus. Milvus furcatus. Elanus furcatus. Fork-tailed Kite. Swallow-tailed Hawk.

Geog. Dist.-Whole of South and Central America, and in North America through the interior north to Minnesota $47^{\circ}$ and North Dakota $49^{\circ}$ lat.; on the Atlantic coast to the Carolinas, rarely to New England; west casually to Colorado. Breeds regularly from Ohio River southward; irregularly north to Iowa, northern Nebraska, southern Wisconsin, and wanders after the breeding season in flocks of various size indifferently over the country, chiefly west of the Mississippi River. Wrinter's south of United States.

In the cotton field region of southeastern Missouri the Swallowtailed Kite is a regular, though not numerous, summer resident, nesting in the adjoining cypress swamps. In the rest of the state it is of very irregular occurrence, though apparently paying oceasional visits to all parts of it. It has been found nesting in Clark Co. in the northeast corner of Missouri by Mr. E. S. Currier of Keokuk, and Mr. John S. Marley took an egg from a nest near Kansas City. Trippe found it breeding in 1872 just across the state line in Iowa. Nearly all observers in 
Missouri have met with the species at one time or another. Audubon saw one near the northwest corner of the state, May 10, 1843, probably near its breeding ground. Dr. Hoy has it in his list of birds observed in western Missouri between April 16 and June 15, 1854. Scott noted it once at Warrensburg, April 15, 1874. In his "Birds of the North-IVest" Dr. Cones writes on page 333: "I had the pleasure of observing it myself in Missouri opposite Fort Leavenworth in May 1864." Early in the eighties Mr. Nehrling found it a pretty regular visitant in Lawrence Co. Mr. Jul. Hurter once observed a troop of 40 in early August in the city of St. Louis remaining in the same locality over a week. In 1884 Mrs. Musick saw them repeatedly in troops of six to eight at Mt. Carmel, Audrain Co. It was also reported from Fayette, May 9 and 25, 1884. There is also one date saved from my old notes lost by fire, August 20, 1885, St. Louis. Mr. Currier and Mr. Praeger give me the following dates of occurrence at Keokuk: March 2 and March 19 (unusually early) and May 13, 1897. Mr. Tindall saw one July 16,1904, at Independenee, and Mr. Bush, August 30, August 31 and September 4, 1906, at Courtney. Fine specimens taken in the state are in the Hurter collection at St. Louis, in the Eimbeck collection at New Haven, in the Kastendieck collection at Billings, and one taken by $\mathrm{Mr}$. Ollie C. Shelley at Independence loaned to the Public Museum of Kansas City.

\section{[328. Elanus leucurus (Tieill.). White-tailed Kite.]}

Milvus leucurus. Falco dispar. Elanus glaucus. Elanus dispar. Blackshouldered Hawk.

Geog. Dist.-From Chile and Buenos Ayres to South Carolina on the east (except West Indies), Indian Territory and Texas in the interior, and northern California on the Pacific. Rare within the United States except in California, where fairly common.

There is one record from southern Illinois where Mr. R. Ridgway observed a pair at Mt. Carmel in the summer of 1863 or 1864. In Mrs. Bailey's "Handbook of the Birds of Western United States," the species is said to occur to the latitude of St. Louis in the interior", but no record of its occurrence in Missouri has been obtained. If it enters our state, it is probably as an accidental visitant from the southwest. 
*329. Ictinia mississippiensis (Wils.). Mississippi Kite.

Falco mississippiensis. Falco plumbeus. Ictinia plumbea. Ictinia subcaerulea.

Geog. Dist.-Southern United States east of Rocky Mountains; south to Guatemala; north to South Carolina, Missouri and Kansas, casually to Pennsylvania, Michigan, Wisconsin and Dakota. Winters south of the United States.

The region of the cypress swamps and cotton fields in the southeast is the only part of Missouri where Mississippi Kites may be called common summer residents, where half a dozen or more may be seen circling playfully above the timber, or hunting peacefully like so many Nighthawks low over the sandy fields. In the eighties a pair made its home for several summers in a small secluded piece of primeval forest in the southwestern part of St. Louis, arriving there near the end of April and remaining till August. As most of the stately trees have since then been removed and the place has become common hunting ground, the gentle, dove-like pair is gone, but a few Mississippi Kites still find their way to St. Louis County and probably nest on the bluffs of the Missouri River. There are no records for the species from that part of the state north of the Missouri River, but the bird is not unknown in the Ozark region of southern Missouri. Mr. Kastendieck has specimens in his collection taken near his home in Billings, Christian Co., and in the early eighties Mr. Nehrling found them "pretty numerous" in Lawrence Co. The writer was pleased to see them lately (May 1906) in pairs in Webster and Howell Counties, in localities where they are likely to survive for some time yet.

*331. Circus hudsonies (Linn.). Marsh Hawk.

Falco hudsonius. Circus cyaneus hudsonius. Falco uliginosus. Falco cyaneus. Circus cyaneus. American Harrier. Mouse Hawk.

Geog. Dist.-Breeds from Alaska, Great Slave Lake, Hudson Bay and Cape Breton Island southward to the southern border of the United States, and winters from about lat. $40^{\circ}$ southward to Panama and Cuba.

The Marsh Hawk was undoubtedly formerly a very common summer resident in the prairie region of Missouri. Audubon met with it near the northwest corner of the state, May 6, 1843. Trippe in 1872 called it abundant; "many breed" in Decatur Co., Ia., just across the state line. Mr. E. S. Currier found it breeding 
in Clark Co. in the nineties, and it is reported as breeling from Kansas City and Montgomery City. The last record comes from St. Charles Co., June 1905, where in the tall grasses of the club grounds it still succeeds in raising a brood. There are probably a few more localities in the marshes of the Mississippi flood plain and on the broad meadows of norther'n Missouri where they can nest unmolested, but such chances become fewer every year. As a transient visitant the Marsh Hawk plays a prominent part still, not so much in spring from the middle of Narch to the midclle of April, as throughout fall and early winter or until deep snow and severe cold drives it farther south. The only time for which we have no records is from the midille of January to the first of March, the perioct of lowest temperature and deepest snow, often enforced by slect and freezing rain. This species is one of the so-called Chicken Hawks of our hunters, who see in every large hawk a competitor and therefore an enemy. It is accused of killing quails, young rabbits and other game, though a careful study of its feeding habits by the Department of Agriculture has shown that it is extremely useful, because feeding principally upon meatow mice and other injurious rodents. While this may be of no concern to the hunter, it should be the aim of the farmer to give, at least on his own grounds, the fullest protection to a benefactor that removes the pest which eats his grain and girlles his fruit trees. Unlike other hawks with which they are commonly confounded, particularly the Cooper's Hawk, the real robber of young chickens, the Narsh Hawks are so little shy that, while hunting low over the ground, they often pass within easy range of the gunner, who seldom fails to kill the poor bird. In spring and fall they serve as scavengers preying upon crippled and dead bircls, which frequently lie far from the spot where they received the shot, and are lost to the gunner.

*332. Accipiter velox (Wils.). Sharp-shinned Hawk.

Falco velox. Falco fuscus. Accipiter fuscus. Nisus fuscus. Astur velox. Accipiter, Astur and Nisus pensylvanicus. Accipiter fringilloules.

Geog. Dist.-Breeds throughout the United States and the wooded parts of the British Dominion and Alaska. Winters from latitude $40^{\circ}$ southward to Central America.

The Sharp-shinned Hawk, for which a better name would be Sparrow Hawk, particularly so because it exactly represents 
the European bird of that name, is well known all over Missouri, but is nowhere common at any time. It is seen oftenest in spring and fall from March 10 to the first week in May and from early in September to about the twentieth of November. Records for December, January and February are few, but it is reported as a rare winter visitant not only from the southern part of the state, but even from the northwestern corner by Mr. E. S. Currier, January 4, 1903, and February 9, 1897, and from the western border December 30, 1902, by Mr. J. A. Bryant of Kansas City. Reports of its breeding in Missouri are also rare; they come from Montgomery City (Parker), Independence (Tindall), and St. Louis County, where Mr. Philo W. Smith, Jr., took a set of eggs in 1904 and saw the birds again in the summer of 1905 . Unlike most other hawks this species does not seem to have suffered great losses in numbers. It has probably never been much more numerous than it is now, for the reason that it is not such an easy mark as the so-called chicken or henhawks of our farmers and hunters. It does not sit around on fence posts and quietly await the approach of the cruel gumner; it is always on the alert and so quick in its movements that it is generally out of range before the beholder has recovered from his astonishment. It is sometimes seen circling high in the air, but its home is in the woods and its hunting is done low over the ground, often at the edge of the forest, along fences and hedges or the varied plant growth fringing our creeks and wetweather branches. Its strategy is surprise; it snatches the frightened bird before it can reach the protecting thicket. Living almost entirely on small birds and young poultry it is decidedly harmful, but its recently acquired taste for the plump and saucy English sparrow has been regarded as a redeeming feature. An additional record of its breeding in the southern part of the state is furnished by Mr. E. S. Woodruff, who took on May 2, 1907, in Shannon Co., a female containing three nearly developed eggs, proving they breed there.

*333. Accipiter cooperi (Bonap.). Cooper's Hawk.

Falco cooperii. Astur cooperii. Falco stanleyi. Accipiter mexicanus. Blue Hawk (adult).

Geog. Dist.-Breeds from Gulf of Mexico to the southern British provinces, Saskatchewan, Alberta and British Columbia. Winters from about lat. $39^{\circ}$ southward to southern Mexico.

In Missouri the Cooper's Hawk may still be called a fairly 
common summer resident in all parts of the state where cultivated fields alternate with remnants of high timber in which it can make its home. There are no records of its occurrence for the period from January 20 to February 19, and it is therefore not safe to class it among the permanent residents, especially since its presence during the whole time from October 30 to March 28 is exceptional rather than the rule. Transient visitants are most numerous from early in April to the first week of May, and in fall from the middle of September to late in October. Wholesale migration has been noticed from about the twenticth to the twenty-sixth of September, when singly or in pairs they have followed each other at intervals of a few minutes, from ten to twenty being visible to the spectator, but, as they are known to advance in a broad front, the whole movement must mean the depopulation of a la"ge district. This is the true chickenhawk for the depredations of which so many harmless species have to suffer, and it is the only hawk that does enough damage to warrant incliscriminate destruction with a view to total extermination. Fortunately for this bold and clever marauder this extremity is not to be expected for a long time to come, as he knows how to take care of himself and his family. He selects his hunting grounds miles away from his aerie, high up and far out on the branch of an old tree in a quiet part of the woods. Poultry raisers should know the different species of hawks; they should know well the one that does most of the harm of which so much eapital is made in order to justify the murder of each and every hawk. But as this is hardly possible, the best plan would be to kill no hawk except the one caught in the very act of making inroads on one's property. Since the worst damage is done among young poultry, the owner should know that the same hawk will come back for more after he has succeeded in carrying off one; he is likely to be back about the same time of day and thereby offers an opportunity to watch for him with gun in hand. Even if missed once or twice-and this may happen to a good marksman-it will secure safety for one's pets, as the cautious hawk will probably not return any more.

\section{Accipiter atricapillus (Wils.). American Goshawk.}

Falco atricapillus. Astur atricapillus. Falco palumbarius. Astur palumbarius.

Geog. Dist.-Breeds in northern North America in the wooded districts north of the range of the Cooper's Hawk, south in the 
Rocky Mountains to New Mexico, and in the West to Eastern Washington and Oregon, being replaced westward by the subspecies striatulus. Winters in the United States, chiefly southward, but is nowhere common.

Missouri collectors know that it is not easy to get a Goshawk for their collections, and taxidermists say that years pass before they get to see one. An exception was made this fall (1906) when Mr. F. Schwarz, our leading St. Louis taxidermist, received five fine adult birds (males and females) within one month from the middle of November to the middle of December. From observations of a long series of years we cannot but class the Goshawk among the irregular and rather rare transient visitants with a majority of dates from March 20 to April 10 and between November 13 and December 20. As we find no record for Jantiary and only one for February we can hardly call it a winter resident, though future observations may supply the missing dates. An exceptionally early fall date is October 8, 1893, obtained from Mr. Currier of Keokuk in the northeast corner of the state, and an equally extraordinary late spring date, May 6, 1843, one of Audubon's notes made near the northwest corner on his journey up the Missouri River to the Yellowstone River.

*337. Buteo borealis (Gmel.). Red-tailed Hawk.

Faleo borealis. Falco leverianus. Buteo aquilinus. Red-tailed Buzzard.

Geog. Dist.--Eastern North America; north to New Foundland, the British Provinees, Hudson Bay, Saskatchewan and Alberta; west to eastern Nebraska and Colorado; south to eastern Mexico. Breeds nearly throughout its range and winters mostly in the Southern States, though some remain even in the Northern States and all return very early to their breeding ground.

Within the last years the Red-tailed Hawk has decreased so much in Missouri at all seasons that not more than one is left where ten were seen twenty years ago. Every hunter and many farmers deem it their duty to kill every one of these singularly defamed and misjudged benefactors, universally, but inappropriately, named Hen or Chicken Hawks. It cannot be disputed that some individuals, when pressed by hunger or by the clamor of a nestful of hungry mouths, take recourse to the chicken yard and relieve a sickly old hen of all her troubles, or teach a careless mother to take better care of her youngsters, 
but their usual business is to remove as many mice and other noxious rodents from the farmer's field as their time and capacity will allow. As a summer resident it used to be well known in all parts of the state; the timber along the streams of our northern and western prairic region suited it as well as the wooded hill-sides in the Ozarks; even the watery southeast was not entirely deserted, though it prefers partly open country to densely wooded regions. The wooded bluffs which border our river valleys and mountain streams are at present the best locations for the stately Red-tail to rear a brood, but it must be very carcful not to betray its aerie, for it is an outlaw in this state, whose latest game and bird protection law strangely exempts from protection all large hawks under that ambiguous term, "chickenhawk." The number of transient visitants is still respectable, but small compared with what it used to be, when dozens could be seen in suitable localities, where mice abounded, on a drive of a few miles through farming country, especially in fall. They are most common from the middle of September to the end of November, but, though some are with us in all kinds of winter weather, the bulk is gone during the two or three months of real winter. Our summer residents are on their breeding grounds in February, but the majority of transients pass through our state in March. They do not stop with us as long as in fall, neither are they seen in troops as they sometimes are on bright October clays majestically soaring high in the air sailing southward. There is a perfectly white albino of this species in the bird collection of the Kansas City Public Museum, but the place and time of capture are not given.

337a. Buteo borealis krideriy Hoopes. Krider's Hawk.

White-bellied Red-tail.

Geog. Dist. - Great Plains from Texas to Dakotas and Minnesota; west to Wyoming and Colorado; east to Wisconsin, northern Illinois and Iowa in migration.

Typical examples of this subspecies seem to be very rare everywhere, but birds closely approaching this peculiar light phase are apparently not very rare in Missouri, even as far east as the Mississippi River. Mr. Praeger killed a fine male near Keokuk, December 22, 1889, and Mr. Currier of the same place gives March 17, 1895, and March 23, 1897, as dates of occurrence. Mr. Charles K. Worthen of Warsaw, Ill., took a specimen on the 
prairie east of that town, where it is occasionally seen in winter. A bird answering the description was observed for several days (November 21-23, 1905) on the grounds of the Horse Shoe Lake club in St. Charles Co., and one taken in spring near Billings, Christian Co., is in Mr. Kastendieck's collection. Considering that the Krider's Hawk is only a subspecies of the Plains, a geographical race known to intergrade with the typical eastern form, it seems plausible that Missouri lies in the belt of intergradation inhabited or visited by the intermediates.

337b. Buteo borealis calurus (Cass.). Western Red-tail.

Buteo calurus. Buteo montanus. Black Red-tail.

Geog. Dist.-Western North America from Mexico to Sitka; east to eastern British Columbia, central Montana, Wyoming and Colorado; in migration to Ontario, Wisconsin, northern Illinois, Nebraska, Kansas and Missouri.

This more or less darker-colored western race, the light extreme of which is said to be scarcely distinguishable from true borealis, is probably not a very rare transient and winter visitant in Missouri, especially in the west. Two specimens taken within one week in the fall of 1888 near Billings, by Mr. J. D. Kastendieck, show distinctly the rufous bars on the tibiae, one of the characteristics of the subspecies, said by some authors to constitute even in the young a persistent feature, in which it differs from the almost or quite immaculate white of the young eastern Red-tail. Mr. Chas. K. Worthen writes that he has taken this subspecies repeatedly near Warsaw during the breeding season.

337d. Buteo borealis harlani (Aud.). Harlan's Hawk.

Falco harlani. Black Warrior.

Geog. Dist.-Gulf States and lower Mississippi Valley; north to Illinois, Missouri, Kansas, casually to eastern Nebraska, Indiana, Minnesota and Pennsylvania.

Probably a regular summer resident in southeastern Missouri, as it has been observed repeatedly in May in different years in Dunklin and Pemiscot counties. A specimen in the collection of Mr. John D. Kastendieck was shot four miles south of Billings, Christian Co., about the middle of November, 1905. A fine adult male was taken on the Mississippi near Warsaw, Ill., opposite the northeastern corner of Missouri, in March, 1879, 
by Mr. Chas. K. Worthen. Two were seen at that time flying up the river.

*339. Buteo lineatus (Gmel.). Red-shouldered Hawk.

Falco lineatus. Falco hyemalis. Buteo hyemalis. Circus hyemalis. Astur hyemalis. Falco buteoides. Red-shouldered Buzzard.

Geog. Dist.--Eastern North America, north to southern provinces of Canada, west to the Plains; south to Mexico. Breeds throughout its range. Winters sometimes in Ontario and the Northern States, but in the Mississippi Valley chiefly south of latitude $39^{\circ}$, returning very early to its breeding places in the North.

As a summer resident the Red-shoulder far outnumbers its cousin, the Red-tail, with which it shares the honor of being called Hen or Chicken Hawk, in all wooded parts of Missouri. It is particularly common on the flood plains of the large river's and in the swampy southeast, where in spring and summer its call is one of the most common sounds. As a denizen of the lowland it follows the river valleys, both north and south, in the prairie as well as throughout the Ozark region, but thanks to the relentless persecution and lack of nesting sites as a consequence of the removal of all trees, even those fringing the watercourses, some parts of the state are already without this great benefactor of the agriculturist. It has been found that $65 \%$ of its food consists of mice and other injurious rodents; less than $2 \%$ of poultry, and the rest of frogs, crawfish, snakes and insects. Though some may be found in every month of the year, the majority leave the state in November and December and do not return until late in February and early March, to the more northern part usually not before the middle of that month. North-bound transients do not tarry with uts as long as the south-bound in the fall from September to November, mostly inexperienced birds of the year, many of which fall to the everready gun of the duck and snipe hunter.

\section{Buteo swainsoni Bonap. Swainson's Hawk.}

Falco buteo. Buteo vulgaris. Buteo montanus Nuttall. Buteo bairdii (juv).

Geog. Dist.-From Argentina to arctic regions; in North America from the Pacific coast east to Manitoba, western Minnesota, Nebraska and micklle Kansas: in migration eastward to Ontario, Michigan, Wisconsin, Illinois, Missouri and Arkansas. 
Accidentally to New England. Winters from Texas southward and migrates sometimes in large flocks.

The Swainson's Hawk was reported by Mr. H. Nehrling as a rare breeder in the region of Pierce City, Lawrence Co., in the early eighties. The writer saw it in Platte Co., opposite Leavenworth, June 2S, 1906, a time of the year when a well-bred Swainson's Hawk should be on its breeding grounds. In Osprey, Vol. 5, p. 109, we rearl: "On April 23, 1901, a pair was found building a nest in an elm that grew on the west bank of Sugar Creek, Linn Co., Kansas." This is only 28 miles from our state line. In has repeatedly been found nesting in central Iowa, and once in southeastern Illinois (Richland Co., 1875) by Mr. E. IV. Nelson. In his migration reports to the Department of Agriculture, Mr. W. G. Savage reports this species from Jasper Co., October 12 and 16, 1902, and from Shamnon Co., September 15 to 24,1903 . Mr. Chas. K. Worthen has taken it at Warsaw, Ill., and further observations will probably show that it is a not uneommon transient visitant, especially westward, and a possible breeder in the northwestern counties.

*343. Buteo Platypterts (Vieill.). Broad-minged Hawk.

Buteo pennsylvanicus. Buteo latissimus. Astur pennsylvanicus.

Geog. Dist.-From northern South America, Mexico and West Indies through Eastern United States to New Brunswick, Ontario and eastern Manitoba. West to Minnesota, eastern Nebraska, Kansas and Texas. Breeds throughout its North American range and winters from the South Atlantic and Gulf States southward.

The Broad-wing is a fairly common summer resident in Missouri, mainly eastward, less commonly westward. It prefers undulating ground where wooded tracts, even of medium-sized trees, adjoin creek bottoms, wet meadows and cultivated fields. Such localities still exist in spite of the universal devastation of timber, in most parts of the state. It seems to shun the swanry southeast and the bottoms of the large rivers as well as the dry ridges of the Ozarks and the drier stretches of the prairie region. None winter with us; migration from the north is brisk during the fourth week of September, when on some days dozens may be seen sailing over in loose flocks. It does not stop over as long as the Red-tail and Red-shoulder, but small parties may be met with during the first half of October, after which the 
species becomes rare, though the last may be noted a month later (November 11, 1897, Keokuk, Currier). Its return in spring is rather irregular; it is seldom seen in March, oftener in early April, but summer residents cannot be expected back in their breeding haunts with certainty before the latter part of the month.

347a. Archibuteo lagopus sancti-Johannis (Gmel.). American Rough-legged Hawk.

Falco sancti-johannis. Falco lagopus. Buteolagopus. Archibuteolagopus. Falco niger. Buteo niger. Black Hawk. Rough-legged Buzzard.

Geog. Dist.-From the Gulf of Mexico north to Newfoundland, Ungava and through the Barren Grounds to Alaska; rare from foot of Rocky Mountains westward. Breeds in Newfoundland, Ungava and from northern Assiniboia and Alberta northward, exceptionally south to northern border of United States. Winters from northern United States southward, but chiefly in the Middle and Southern States, being influenced largely by the amount of snow which covers the ground, depriving it of its favorite food-the mearlow mice-for which it often hunts in the twilight. Like most of our winter visitants the Rough-leg is of irregular occurrenes in Missouri, both in numbers and time of arrival and departure. It is never seen before the first of November and hardly ever after the first of April (April 6, 1902, Keokuk, Currier). The bulk eomes about the latter part of November and has left us by the nicldle of March. In open, moderately cold winters the fields, pastures, meadows and marshes of northern Missouri are weIl supplied with this indefatigable mouser, which, somewhat resembling a Marsh Hawk, flies low over the ground, every once in a while hovering for a few seconds to subject the ground to a closer examination, or pouncing on its unlucky quarry.

[348. Archibuteo ferrugineus (Licht.). Ferruginous Roughleg].

Falco ferrugineus. California Squirrel Hawk.

Geog. Dist.-Western North America, east to castern Dakotas, eastern Nebraska, middle of Kansas and Texas. North to northern Assiniboia; south into Mexico. Breeds from Utah, Colorado and Kansas northward; in California in the interior valleys to San Diego Co. 
It has been taken in Illinois, Iowa and Wisconsin, and is said to oeeur throughout Nebraska and Kansas, being even a common breeder in the western parts of these states. It should be looked for in our western and northern prairie region, where it will undoubtedly oceur as an oeeasional transient visitant. It is said to be easily reeognized by its large size, pale ashy-eolored tail, and generally light-eolored under parts, strongly eontrasting with its rufous legs (Bendire).

349. Aquila chrisä̈tos (Linn.). Golden Eagle.

Falco chrysaëtos. Aquila canadensis. Aquila fulva Nuttall. Ring-tailed Eagle.

Geog. Dist.-Northern Hemisphere; in America from Central Mexico to the Aretie eoast and Aleutian Islands; ehiefly western. Breeds in mountainous regions. In winter irregularly over most of United States.

In Missouri now a rather rare winter visitant between Oetober 1 and April 1. Formerly much more eommon, as attested by the large number of mounted specimens in private colleetions or used for ornamental purposes in public places.

*352. Haliaeetus leucocephalus (Limn.). Bald Eagle.

Falco leucocephalus. Falco ossifragus. Falco Washingtonii. Aquila leucocephala. Haliaëtus Washingtoni. Bird of Washington. White-headed Eagle. Black Eagle. Gray Eagle. American Eagle. (National Emblem).

Geog. Dist.-Together with the lately separated subspeeies, alascanus, Northern Bald Eagle, the whole of North Ameriea, from Mexico to the arctie coast and from Newfoundland to Kamchatka, the new subspeeies inhabiting the region north of the United States in summer, but going southward in winter. Sinee the southern form, which formerly nested throughout its range from Florida to California and from Texas to Minnesota and Maine, is now driven out of most of its former breeding grounds in the upper Mississippi and Missouri Valleys, the Bald Eagles which still visit us in small numbers in fall, winter and spring, are probably mostly of the Northern subspecies.

That the Bald Eagle was formerly a well-known breeder along all our larger rivers there is ample proof. On April 25, 1833, when near the mouth of Nodaway River on his way up the Missouri, Prince Max of Wied wrote in his Journal: "White-headed 
Eagles nest frequently on high trees along the shore." Audubon mentions Bald Eagles repeatedly on his journey through the state. When near the mouth of the Gasconade River on April $27,18 \pm 3$, he speaks of curious holes in the cliffs, where the Bald Eagles and Turkey Buzzards entered toward dusk. When between Fort Leavenworth and St. Joseph on May 6, 1St3, he discovered two nests of White-headed Eagles. And again the following day, north of St. Joseph, he saw White-headed Eagles on nests. Dr. Hoy names Haliaetus leucocephalus in his list of birds, made in western Missouri between April 16 and June 15, 1854. The swampy region of southeastem Missouri is the place where Bakly held out longest as a resident, but as long ago as the early nimeties chances to rear a brood of young Eagles grew very slim, when some of the native market hunters turned into plume hunters. There may still be a few pairs breeding in the cypress swamps, but as a breeder the species must be considered nearly extinct in Missouri. Our new game law means to protect eagles in as much as it does not mention them among the birds exempt from protection, but unfortunately the public does not understand it, and the game wardeus lo not care, or else the daily press woukd not continue to make heroes and benefactors of the fellows who wantonly slaughter such a harmless creature and one of the grandest ornaments of any landscape wherever it appears. Since the above was written my son Berthold, discovered the existence of at least one pair breeding in the state. On May 23, 1907, he found chained to the porch of a hotel at New Madrid a fully-grown young lately captured from an old eagle's nest in a bayou near New Madrid. Two young ones were reared, but one could fly and got away. At the same place he met an old trapper, who boasted of having killed within 37 years 487 Eagles, catching them in traps baited with fish.

\section{*355. Falco mexicanus Schleg. Prairie Falcon.}

Falco polyagrus. Falco lanarius var. polyagrus. Falco lanarius mexicanus. Lanner.

Geog. Dist.- Western North America from Mexico to Assiniboia and British Columbia: east to the Dakotas, Nebraska and western Missouri; west to California. Breeds throughout its range, and retires from the northern and middle states in winter. Casually to Illinois (Rock Island, Mount Carmel, Bridgeport and Paris) in migration (September and March 19). 
Has been found breeding in Nodaway Co., where April 28, 1880, two eggs were collected near Maryville, now in the collection of Captain B. F. Goss in Milwaukee. Mr. John A. Bryant of Kansas City writes that he took a Prairie Falcon near that city in 1887.

*356. Falco peregrinus anatum (Bonap.). Duck Hawk.

Falco anatum. Falco communis var. anatum. Falco peregrinus. Peregrine Falcon.

Geog. Dist.-From Chile to the arctic circle and from Greenland to the Mackenzie, being replaced on the North Pacific coast from Oregon to the Aleutian Islands by the subspecies pealei. Breeds locally throughout its North American range, except on the southern and western Plains. Winters in the southern United States and southward, but returns with the teals and blackbirds.

That the cliffs along our great rivers were formerly the homes of many of these noble falcons is evident from the notes of early travelers. Prince of Wied mentions the nesting of Peregrine Falcons in the rocky cliffs near Rockport, April 14, 1833. Audubon, when near the mouth of the Gasconade River, April 27, 1843, wrote in his dairy: "Harris saw a Duck Hawk about the cliffs." Again when between Leavenworth and St. Joseph on May 4, 1843, he names the Falco peregrinus among the many birds seen on that day. Dr. Hoy, on the day following his departure from St. Louis, steaming up the Missouri, makes this entry in his diary, April 14, 1854: "Saw a Duck Hawk fly to her acrie in the face of an inaccessible cliff with a duck in her claws to feed her young." During the eighties and early nineties a few pairs still nested along the Mississippi River in the vicinity of Grand Tower, near the mouth of the Meramee, near Grimsley station below Cliff Cave, between Alton and Grafton, also on some of their old stands on the lower Missouri, but have since deserted their haunts and are not likely to take them up again. In the collection of Mr. Charles L. Eimbeck at New Haven is a most beautiful pair of Duck Hawks taken near Bluffton, where they had a nest in the cliffs. There may still be a few pairs nesting in out of the way places in the Ozarks, but their doom as breeder's in Missouri has been sealed, and even as transient visitants they are decided rarities, while formerly they used to be pretty regular sights about the blackbirds' roosts and duck and snipe grounds in March and October. 
357. Falco columbarius Linn. Pigeon Hawk.

Falco (Aesalon) lithofalco var. columbarius. Falco temerarius. American Merlin. "The little corporal."

Geog. Dist.-Breeding, except in mountainous regions, north of lat. $43^{\circ}$; in Canarla throughout wooded parts from Newfoundland to Alaska. In winter from southern United States to West Indies and northern South America.

In Missouri a rather rare, some seasons a fairly common, transient visitant in Mareh and April, and in October; only a few winter reeords (January and February). Latest spring date, May 6, 1843, when Audubon saw a Pigeon Hawk north of St. Toseph.

358. Falco richaridsonil Rielgw. Richardson's Merlin.

Geog. Dist.-Interior and western Plains of North Ameriea from Mississippi River to the Paeific eoast and from Mexico to Saskatehewan and Alberta.

Is reported from eastern Kansas and southeastern Nebraska, and should be looked for in migration or in winter in western Missouri. Mr. J. D. Kastendieek found a dead one hanging on a fence in Stone Co., about nine miles south of Billings. Mr. Chas. K. Worthen took one at Warsaw, Ill., and the species has repeatedly been taken in late autumn as far east as southern Wisconsin. It is probably not so very rare, but easily mistaken for a Pigeon Hawk, from which it may be distinguished by lighter colors, slightly larger size, and by five dark and six grayish-white bands in the middle tail feathers, while the Pigeon Hawk has only four dark and five lighter bands.

*360. Falco sparverius Linu. Ameriean Sparrow Hawk.

Tinnunculus sparverius. American Kestrel.

Geog. Dist.-From northern South America through eastern North Ameriea to Great Slave Lake; west to Colorado, eastern Wyoming and eastern British Columbia, being replaced in the West by the subspeeies phalaena. Breeds from Florida to Newfoundland, and from Louisiana northward throughout its range. Winters from about lat. $40^{\circ}$ southward, but ehiefly south of the Ohio River.

This is undoubtedly the most numerous and, because living in the open, the most frequently seen of all hawks. It is a eommon summer resident on all eultivated lands of the state, arriving in 
March and leaving in October. A few remain all year from the Missouri River southward, especially in open winters; others remain late and return early, soon after the backbone of the winter is broken, about the middle of February, but the species does not become generally distributed before the middle or end of March. Transients are not much in evidence in spring, but large numbers, mostly birds of the year, are present in August and September, when, together with Mourning Doves, they frequent wheat stubble in search of grasshoppers, while the Doves pick up the scattered grain and weed seeds. Of late several pairs winter in St. Louis, captivated with the beauty of our English Sparrows, an article of diet to which they have recourse when nothing better ean be had.

\section{Subfamily Pandionina. Ospreys.}

*364. Pandion haliä̈tus Carolinensis (Gmel.). American Osprey.

Pandion carolinensis. Pandion haliaetus. Fish-hawk.

Geog. Dist.-From northern South America and the West Indies to the aretic circle, throughout North America from Atlantic to Pacific, and from Newfoundland to Alaska. Breeds throughout its North American range, and winters from the South Atlantic and Gulf States southward.

Like the Bald Eagle, the Osprey, commonly called Fish-hawk, was formerly a well-known summer resident in the same localities and, like the Eagle, its present status as a breeder in the state is one of uncertainty and doubt. It is only within the last decade that this condition has been brought about, for ten years ago the Fish-hawk was not uncommon during the breeding season in several parts of the southeast. Its home was to be found not only along the Mississippi and Missouri Rivers, but also along such streams as the Gasconade and Osage. Mr. B. T. Gault observed it in May, 1888, in the White River bottom below our southern state boundary. Thirty years ago, before Creve Coeur Lake was connected by railroad with St. Louis, a pair had its home in the vicinity of that lake. On June 26, 1906, the writer saw an Osprey in Atchison Co., the northwest corner of Missouri (from where Audubon reported its presence on May 9, 1843), but whether it should be classed among the summer residents, or only as a summer visitant, could not be 
ascertained. As a transient visitant it is sometimes seen in April and in fall from the middle of September to the first of November, rarely later (November 12, 1894, Keokuk, Currier). A perfectly white Albino Osprey was killed on the Mississippi River near Quincy and is in the fine collection of Mr. Slingerland of that city.

\section{Suborder Striges. Owls.}

\section{Family Strigidae. Barn Owls.}

\section{*365. Strix pratincola Bonaj. American Barn Owl.}

Strix americana. Strix flammea. Ulula flammea. Strix flammea americana. Strix tlammea pratincola. Monkey-faced Owl.

Geog. Dist.-Mexico and United States, north to lat. $41^{\circ}$ in the Eastern States, to $16^{\circ}$ on the Pacific coast; rarely to New England, Ontario, Michigan, Wisconsin and Minnesota. Said to leave the Northern States in winter: non-migratory southward.

In Missouri a rather rare resident, possibly not as rare as formerly and spreading. At present found only in the northern and western prairie, and in the Ozark border regions, but not in the Ozarks and southeast, which are too densely wooded to suit this friend of the open land. According to $\mathrm{Mr}^{*}$. H. Nehrling, the species was a fairly common breeder in the vicinity of Pierce City, Lawrence Co., as long ago as from 1882 to 1887. Eggs have been collected at Independence by Mr. Sheley and at Montgomery City by Mr. Parker. Its occurrence in Clark Co. is demonstrated by MM. Praeger and Currier, and at Warsaw, opposite Alexandria, by Mr. Worthen. Several specimens have been captured in the vicinity of St. Louis, some of which found their way into collections.

\section{Family Bubonidae. Horned Owls, ete.}

*366. Asio wilsoniands (Less.). American Long-cared Owl.

Otus wilsonianus. Otus americanus. Strix olus. Ulula otus. Otus vulgaris var. wilsonianus.

Geog. Dist. - From the tablelands of Mexico throughout the United States and in the British Possessions as far north as the forests extend. Breeds throughout its range and winters from British Columbia and northern United States southward. 
The Long-eared $\mathrm{Owl}$ has been found breeding in different parts of Missouri. Mr. Currier found it May 4, 1902, in Clark Co.; Mr. Parker in Montgomery Co.; MM. Shcley, Bush and Tindall found it in Jackson Co. Mr. Sheley has a fine set of six eggs in his collection at Independence. Mr. Bush of Courtney writes that they breed in the deepest recesses of the bottom, and nest in willows. Mr. Tindall of Independence found several pairs nesting in old crows' nests, and says they begin setting from about March 20 to 25. Specimens have been killed during the breeding season in St. Louis and St. Charles Co., but there are at present no such records from the whole region south of St. Louis and St. Clair Co., where Mr. Prier of Appleton City found them breeding in 1906 . Specimens without date are in the collections of Dr. Kizer at Springfield and Mr. Kastendieck at Billings. That the species occurs in flocks in winter is attested by Mr. Hurter, who saw a flock of 30 , January 30,1873 , in one tree in the Mississippi bottom near St. Louis; also by Mr. Bush, who writes from Courtney that they are abundant in river bottoms, with from 50 to 60 on one tree.

*367. Asio accipitrinus (Pall.). Short-eared Owl.

Strix accipitrinus. Strix brachyotus. Ulula brachyotus. Otus brachyotus. Brachyotus palustris. Marsh Owl. Prairie Owl. Cat Owl.

Geog. Dist.-Cosmopolitan except Australia and some islands. In North America, throughout United States and British Provinces north to the Aretic Sea, and from Greenland to Point Barrow and the Aleutian Islands. Breeds locally from Virginia, Indiana, Missouri, Kansas, Colorado and southern Oregon northward, and winters irregularly from northern United States southward, chiefly south of lat. $40^{\circ}$.

There are several recorls of its breeding in Missouri. A nest containing downy young was found in 1897 near St. Francisville, Clark Co., and another by Mr. Philo W. Smith, Jr., June 2, 1905, near Maple Lake in St. Charles Co. They are also given as breeders in Johnson Co. by Mr. A. F. Smithson of Warrensburg, and in St. Clair Co. by Mr. C. W. Prier of Appleton City. Numerous records and specimens show that as winter visitants Short-eared Owls are well distributed over the northern and western prairie region, where they are irregularly common from October 10 to April 1. Sometimes they invade the Ozark border region, as specimens in the collections at Springfield (Leblane and Kizer) and at Billings (Kastendieck) prove. Mr. Prier reports having 
met with a flock of fifty in the fall of 1905 near Appleton City, and smaller troops are not unusual on the marshes of the Mississippi flood plain north of the Missouri River.

\section{*368 SrRnium varium (Barton). Barred Owl.}

Strix nebulosa. Syrnium nebulosum. Ulula nebulosa. Hoot Owl.

Geog. Dist.-Eastern United States and southern provinces of Canada from Nova Scotia to Winnepeg; south to northern Texas, being replaced in the Gulf and South Atlantic States by the subspecies alleni. Breeds throughout its range, and is nonmigratory except in the most northern part of its range.

In Missouri, in spite of all persecution, still a fairly common resiclent in all portions of the state, mainly in the heavy timber of the river bottoms, where there are natural cavities in tall trees, particularly sycamores, in which it can hide and nest. Unlike all other owls, it is often heard to hoot and laugh during the daytime, betraying its whereabouts to the hunter, who deems it his cluty to go for it and try to kill it. With all other owls, except the Great Horned Owl, the Hoot Owl is now protected by the new game law of Missouri, but as long as the population is not educated enough to understand and appreciate such a law, and as long as the newspapers do next to nothing in informing and instructing their readers in regard to bird protection, no law will save the owls and hawks from being killed whenever opportunity offers. The slow process of elucidation through Nature study in the schools is the only hope that in course of time bird protection laws will receive that measure of sympathy which is necessary for their enforement.

[370. Scotiaptex nebulosa (Forster). Great Gray Owl.]

Strix cinerea. Scotiaptex cinerea. Syrnium cinereum. Syrnium lapponicum var. cinereum.

Geog. Dist. - The wooded districts of northern North America from Lake Superior and Hudson Bay to the Pacific, and north to the arctic circle and through Alaska to Behring Straits. In winter irregularly to northern borker of United States, casually as far south as New Jersey, Pennsylvania, Ohio, Indiana, Illinois, Iowa, Wisconsin, Nebraska, Wyoming, California.

Though at present no record is on hand, this interesting bird may come occasionally as far south as Missouri, as it was taken once near Omaha, Neb., December 12, 1893, and in some winters 
reaches the United States in comparatively large numbers. For instance, between January 5 and March 3, 1897, six specimens were captured in one county (Aitkin Co.) in central Minnesota. In the winter of 1890-91 such a heavy flight of this Owl occurred in parts of New England that a single taxidermist in Bangor, Me., received twenty-seven specimens. Another considerable flight took place in the winter of $1842-43$, when seven were taken in Massachusetts alone. We sometimes hear or read of an Owl "as big as an eagle" having been killed; such cascs should be investigated as they may enable us to remove these brackets. Since the above was written another great flight took place in the winter of 1906-07 (Auk. Vol. XXIV, 1907, p. 215).

[371. Cryptoglaux tengahami richardsoni (Bonap.). Richardson's Owl.]

Nyctale richardsoni. Nyctale tengmalmi richardsoni. Strix tengmalmi. American Sparrow Owl.

Geog. Dist.-Northern North America from the limits of trees in Alaska down to the Gulf of St. Lawrence. In winter irregnlarly to the northern border of United States, rarely to Oregon, Colorado, Nebraska, Iowa, Minnesota, Wisconsin, Illinois and New England.

Since our neighboring states have had calls from this rare northern guest (Iowa; Illinois, October 15, 1884, December 26, 1902; Nebraska, December 10, 1892, Lincoln), there is some hope that one of our future observers will find it, if his attention is aroused, for which purpose the species has been entered in this list. The American Sparrow Owl is said to be strictly nocturnal, carefully hiding during the day, and therefore difficult to find, but it may not be as rare as generally supposed. From the Saw-whet it can be distinguished by its slightly larger size, darker color, spotted instead of streaked head, and brownish barred legs and feet.

*372. Cryptoglaux acadica (Gmel.). Saw-whet Owl.

Strix passerina (Wils., 1812). Strix acadica. Ulula acadica. Nyctale acadia (in juvenile plumage albifrons, frontalis, kirtlandi). Acadian Owl. Kirtland's Owl.

Geog. Dist.-Breeding from about latitude $50^{\circ}$ southward to latitude $40^{\circ}$, in the mountains of the West south into Mexico. In winter, in California to Monterey, in the Mississippi Valley 
to Louisiana, on the Atlantic coast to Virginia. Being a great hider in day-time, this little owl is regarded as rare everywhere.

The Saw-whet has repeatedly been taken, alive and dead, within the city limits of St. Louis in winter, and is reported as a rare winter visitant by $\mathrm{Mr}$. Worthen, Mr. Praeger and Mr. Currier, but a late date, April 16, 1893, given by the latter, would perhaps indicate that the bird was on its breeding ground when captured. That it breeds oceasionally in Missouri is demonstrated by the discovery of a nest with three young ones, in the spring of 1904, by Mr. John E. Müller of Bluffton, Montgomery Co.

*373. Megascops asio (Limu.). Sereech Owl.

Strix asio. Scops asio. Strix naevia. Surnia naevia. Ephialtes asio. Mottled Owl.

Geog. Dist.-Of the nine subspecies, this is the one which inhabits the eastern United States from Georgia northward to Newfoundland, New Brunswick, Ontario and southeastern Manitoba; west in the United States to about the 100th meridian. Gencrally non-migratory, breeding throughout its range.

In all parts of Missouri a well-known resident, now apparently preferring the vicinity of human habitation and nesting wherever it finds a suitable site in tree-holes or about buildings, using, if permitted, bird-boxes for nosting and roosting. When living in a suburb of St. Louis the writer reared a nestful of downy young (5), which were presented to him by Mr. Philo IV. Smith, Jr. When they were fully fledged and supposedly able to care for themselves, they were given their freedom. A few of them remained on the place, often coming to the lawn on summer evenings, in pursuit of locusts, beetles, katidids, etc. During the winter they used some of the bird-boxes for a roost. The following spring a pair made a nest in a compartment of a tenroom fancy bird-house, about twelve feet from our house, and successfully raised a brood, undisturbed by the numerous tenants of some of the other compartments in the same bird-house, namely, a pair of Fliekers, a pair of House Wrens, two pairs of Martius and a few English Sparrows. When the fancy birdhouse was demolished by a severe wind-storm, a suitable box with a three-inch circular hole was set up in a tree near the house, which the Screech Owls continued to occupy for several years. 
*375. Bubo virginianus (Gmel.). Great Horned Owl.

Strix virginianus. Ulula virginiana.

Geog. Dist.--Of the six subspecies belonging to the North American bird-fauna, this is the one which inhabits Eastern North America from Costa Rica to Laborador and Newfounclland; west to the Plains; non-migratory, except in its most northern habitat, and breeding throughout its range.

Its large size and loud voice, together with an innate persistence of abode and crepuscular rather than strictly nocturnal habits, account probably for the opinion of nearly all observers that it is a common bird, while an equal number of Saw-whet Owls would be classed among the rarest. The fact that none of our observers omits it from his list is sufficient proof that it occurs in all parts of the state, wherever old and partly hollow trees are left standing to afford the big bird shelter and a nesting site. No one contradicts the often repeated statement, that this powerful bird of prey is destructive to poultry, but hardly any one will maintain that the attacks are made during the day. A natural inference is that, if the farmer would take proper care of his fowl and keep them at night where they belong and not in the open all winter, there would be little loss through his owlship's faults.

In the spring of $1878 \mathrm{Mr}$. Julius Hurter presented me with a fluffy young Bubo, which became at once the pet of the household. During the summer I often took him out with me to the woods and, placing him where he could be seen, had the satisfaction of attracting the bircs to us from all sides. When he was full grown his grip became uncomfortably tight and his claws unbearably pointed. I decided to trim them, but his owlship resented the operation in such an ugly manner that I thought best to leave him alone for a while. I gave him a roomy cage with a box in which he could hide if he wanted to. I hoped to use him in migration time to attract hawks, as they do with Bubo ignavus in Europe. This plan was never realized, but Hoo-hoo, as we call him, gave us much pleasure in other ways, and after twenty-nine year's' confinement he is to-day as hale and hearty as ever. During seven years of his life he had a companion in the shape of a burly female, much bigger than himself. In spite of this difference in size he was the boss, and she did not attempt to touch their daily ration of raw meat until he was satiated and had withdrawn. Her end was a rather mysterious affair. After she had deposited her second egg on 
the coldest day of one of our coldest winters, with 20 degrees below zero (the cage was under a porch, but otherwise not sheltered from the cold) the companion of seven years was found lying dead on the floor of the cage and her hubby occupied with tearing the flesh from her breast. The eggs had burst with the intense cold. Since that day he has remained a widower, though during the thirteen years we lived in the suburbs he came near getting another partner several times. His hooting, heard in the dead of night for half a mile or more, attracted others of his kind, and twice, females, which remained too long in the neighborhood, were shot by neighbors. One female in particular was very persistent, tried her best to get into the cage to him, and left unwillingly when we approached the eage in the early morning after a night made memorable by incessant hootings of hō hoo hō, hō, hō, by him and answers of ho ho ho ho ho by her. For years his hooting was begun in September and kept up till February; in clear, cold moonlit nights he was noisiest: in dark, eloudy or rainy nights he was not hearl. Sometimes he would not hoot much, at other times he would hoot for hours until he was really hoarse and his usual agreeable deep bass became grating to the ear. Since he was moved back to town again in 1902, he has given up hooting, though his general appearance does not show any signs of old age, and his dress, which he gets anew in summer, has the same depth and freshness of color as ever. He is never left without water to drink, but takes a bath only in very hot weather, though he likes to sit in the rain with wings spread wide. He is fed once a day before dusk, his daily ration being a fourth of a pound of raw meat in small pieces, varied sometimes with a rat, mouse, sparrow, or whatever else is obtainable, but he rejects moles and toads. When mice and sparrows are offered at the same time, he will swallow all the mice before he touches a sparrow. Such small fry he swallows entire, after breaking the bones by rolling the animal with his tongue in the beak. If handed more than he can eat at one meal, for instance a grown chicken, he will invariably store the rest in the darkest corner of his box, but won't touch it any more when it gets too stale. He likes to be spoken to and seems to know those who care for him, comes to them and takes food out of their hands, but he hates dogs, sticks and boys. Once I found a crow that could not fly and took it home for experimenting. I put it in the eage with the two owls. Great was my surprise to see that not only was 
it not harmed at all, but the crow actually became boss in the cage. When the meat was placed on the floor of the cage, who came and ate first? - the crow! Only after it had finished eating came Hoo-hoo, and what he left went to the big she-owl. After living together thus harmoniously for about a year, the crow escaped from the cage and was never seen again. Hoohoo had several opportunities for deserting, but having been confined from babyhood he could not fly well and did not get far before we caught him by throwing a sack over his head and, for his own good, put him back into his safe quarters.

375a. Bubo virginianus Pallescens Stone. Western Horned Owl.

Bubo virginianus subarticus (Hoy).

Geog. Dist.-Western United States from western Nebraska westward: southward to Mexican tablelands; north to Manitoba, Assiniboia, Alberta and British Columbia. Casually east to Wisconsin and northern Illinois.

A specimen in the collection of Mr. Chas. L. Eimbeck was taken near New Haven.

\section{Nyctea nyctea (Linn.). Snowy Owl.}

Strix nyclea. Surnia nyctea. Nyctea nivea. Nyctea scandiaca var. arctica.

Geog. Dist.--Northern portions of the northern hemisphere; breeding in America from eastern Greenland and Laborador, through the Barren Grounds and arctic regions to the islands of the Behring Sea and through northern British Columbia to Sitka. In winter to the southern provinces of Canada and irregularly to northern, seldom to southern, United States, as far south as South Carolina, Louisiana, central California and Bermuda. Records of large flights are those of 1876-77, when 500 were reported in New England alone; of 1892-93 and 1901-02; and the largest of all in the winter of 1905-06, when Mr. R. Deane (Auk. Vol. 23, p. 283) collected records "of some eight hundred specimens from localities scattered from Nova Scotia to Nebraska and from Manitoba to Missouri."

In Missouri known only as a rare visitant from the middle of November to the end of February, but this apparent rarity may partly be due to the almost total lack of observers or collectors throughout the northern part of the state. Known records are: November, 1905, one killed near Malta Bend, Saline Co., by Mr. 
Plosser and mounted by Mr. Emmett Cole; November 18, 1905, a female taken near the city limits of St. Louis (Wellston) and mounted by Mr. F. Schwarz; two records from Keokuk, November 20, 1895, and December 6, 1886; one from the vicinity of St. Louis in the Hurter collection, December 29, 1875; two from Montgomery City by Mr. Parker, January 13 and February 10, 1902; and one from Jasper Co., January 23, 1906, where two birds were encountered by Mr. Johnson of Carthage, Mo., who killed one of them, a gray one, from a fence-post, but let the other, a pure white one, get away. For this last record I am indebted to Mr. Philo W. Smith, Jr. A fine specimen in the Blanke collection was killed near St. Charles.

[377a. Survia ulula Caparoch (Müll.). Ameriean Hawk Owl.]

Strix hudsonica. Surnia hudsonica. Strix funerea. Surniaululahudsonica.

Geog. Dist.- Northern North America, breeding from Hudson Bay throughout wooded regions to northern Alaska, rare in the East except Newfoundland; in the West, occasionally as far south as northern Montana and Assiniboia. In winter to southern provinces of Canarla and northern border of United States, rarely to Pennsylvania, Ohio, Incliana, Illinois, Nebraska and even to Mississippi (Corinth, January, 1882).

In Missouri it has been reported to the Department of Agriculture from Mount Carmel, Audrain Co., by Mrs. M. Musick, December 26, 1884, March 10, 1885, and January 28, 1886; but as no specimen has been secured, there is the possibility of a confusion with the Short-eared Owl, which is sometimes called Hawk Owl, because seen hunting in bright daylight.

\section{Order PSITTACI. Parrots, Macaws, Paroquets, etc.}

Family Psitracide. Parrots and Paroquets.

\section{Conurus carolinensis (Linn.). Carolina Paroquet.}

Psittacus carolinensis. Orange-headed Parrot. Parakeet.

Geog. Dist.-The former home of the Paroquet included the Southern States from eastern Texas to Florida, north to the Carolinas on the Atlantic slope, and in the Mississippi Valley north to Ohio, Indiana, Illinois, Iowa and Nebraska. They were non-migratory birds, gregarious, of a roving disposition, and in their extended flights in search of food reached Pennsylvania and New York, southern Michigan and southern Wisconsin and followed the Arkansas River to Colorado. 
Of their former abundance in Missouri we have the testimony of several early explorers. Ascending the Missouri River, Prince of Wied enters in his diary, April 14, 1833: "On several plantations we saw troops of Paroquets sitting on corn-stalks" (probably corn of the preceding year left in the field). He was then in the region of Boonville. On the following day (April 15, 1833), when west of Brunswick, he writes: "Above Wakonda Creek (Carroll Co.) we stopped for the night; the hunters dispersed, but brought back nothing but Paroquets. Again on April 21, above the Kaw River, he mentions the shooting of Passenger Pigeons and Paroquets. Also on April 23, north of Fort Leavenworth, he says, "the hunters procured only paroquets." On his return down the river in the spring of 1834 , Prince of Wied observed Paroquets when in the region of Atchison Co., Nay 14, 1834. In his "Narrative of a Journey Across the Rocky Mountains," J. K. Townsend wrote, April 7, 1833, at Boonville: "We saw here vast numbers of the beautiful Parrot of this country, the Psittacus carolinensis. They flew around us in flocks, keeping a constant and loud screaming, as though they would chide us for invading their territory; and the splendid green and red of their plumage glancing in the sunshine, as they whirled and circled within a few fect of us, had a most magnificent appearance. They seemed entirely unsuspicious of danger, and after being fired at only huddled closer together as if to obtain protection from each other, and as their companions are falling around them, they curve down their nceks and look at them fluttering upon the ground, as though perfectly at a loss to account for so unusual an oceurrence. It is a most inglorious sort of shooting, downright, cold-blooded murder." When Audubon, Harris, Bell and Squires went up the Missouri River in 1843 , they did not meet with any paroquets until they came to Independence, where on May 2, 1843, Bell killed two; on the next day near Fort Leavenworth he again "killed one out of a great number." On May 4 seventeen Paroquets were seen between Leavenworth and St. Joseph, and on the 7th, when nearing the corner of the state, Paroquets were "plentiful." Passing the northwest corner of Missouri on May 8, Audubon again noted "Parrakeets;" also when in the neighborhood of Omaha on the 10th, with the remark: "Parrakeets and Turkeys plentiful." On his return trip in the fall of the same year, he speaks of the killing of four "Parrakeets," October 9, 1843, the day before reaching Fort Leavenworth. When Dr. P. R. Hoy visited the state on his tour of exploration of western 
Missouri in 1854, Paroquets were still plentiful in some localities. April 27, 1854, he writes at Boonville: "Went on the river bottom: got one Parrakeet." At Chillicothe, May 16, 1854: "Went on the extensive bottoms of Grand River, so celebrated for rich land and heavy timber; we found the principal forest trees to be black walnut, burr oak, cottonwood, sycamore, hackberry, shagbark hickory, pecan, coffee bean, honcy locust and black birch, all of which grow to an unusually large size.

Parrakeets are abundant about the large sycamores, Platanus occidentalis, in the hollows of which they roost and nest." Mr. Chas. 11 . Worthen writes that about 18.55 a flock of Paroquets was seen on Fox Island in the Mississippi River by his brother. Mr. H. C. Masters of Atchison, Kan., an early settler of westem Missouri, says that when he located at Iatan, Platte Co., Mo., in the early fifties, there were hundreds of Paroquets in the Missouri River bottom. F. V. Hayden, in his report on the Geology and Natural History of the Upper Missouri, says of the Paroquets: "Very abundant in the Mississippi Valley along thickly wooded bottons as far up the Missouri River as Fort Leavenworth, possibly as high as the mouth of the Platte, but never seen above that point." That was from 1855 to 1857 . Hon. J. R. Meade of Wichita, Kan., relates that when he started from Leavenworth over the old wagon trail to Lawrenee in the spring of 1859 , the beautiful scenery was varied by flocks of gailyfeathered Paroquets, chattering in the tree-tops. With the end of the fifties records of occurrence all at once cease, though we read in Goss' "Birds of Kansas" that as late as spring, 1858, "a small flock reared their young in a large hollow limb of a giant sycamore tree, on the banks of the Neosho River near Neosho Falls." Captain Bendire frequently saw fiocks in the fall and winter, 1860-61, at Fort Smith, Ark., but in Missouri flocks of Paroquets seem to have faded away with the fifties. Fron that time they became rarer and rarer. Dr. A. F. Eimbeck saw the last November 3, 1867, in Warren Co., seven Paroquets in an orchard; and his brother-in-law saw the last in 1865 near Pomme de Terre Creek in Franklin Co. On a recent tour through Europe, Dr. Eimbeck, who has a fine specimen in his collection of mounted birds, found only one individual in the zoological gardens he visited (in Hamburg); he considers the species nearly extinct.

That the lower Missouri River from Omaha to its mouth was once a favorite resort of large numbers of these beautiful and 
lovely birds, there is no doubt, and we can easily understand why they liked the region, when we learn that they were fond of cockle-burs, hackberries and giant sycamores. Some of the islands and stretches along the Missouri River are covered with cockle-burr to this day and the river bottom is the home of the lackberry tree and the giant sycamore, in the spacious holes of which they liked to roost and nest. Mr. B. T. Gault wrote in 1888: "At one time Paroquets were very plentiful at Paroquet Bluff between Newport and Batesville on the White River, but none have been seen there for at least eight years." Dr. C. H. Merriam reported in the Auk, Vol. IX, 301, that in the fall of 1891 Mr. Thurman S. Powell saw two Paroquets in the old Linchpin camping grounds in Stone Co. Lately Mr. Thurman S. Powell informed me that on July 18, 1905, a Paroquet was seen and watched for some time at the gate in front of the postoffice at Notch, Stone Co., by the postmaster, Mr. Levi Merrill, who knew Paroquets from Indian Territory. The latest report comes from Atchison, Kan., on the Missouri River between Leavenworth and St. Joseph. Mr. Geo. J. Remsburg of Oak Mills, Kan., to whom I am indebted for this interesting report, writes that in August, 1904, his brother, Mr. Wirt Remsburg, killed a Paroquet on the Remsburg fruit farm near Potter, Kan., a few miles south of Atchison, opposite Platte Co., Mo. The bird was alone and was observed several days before it was killed. It made a loud chattering noise as it flew about the country and attracted much attention. Mr. Remsburg positively identified it as a Paroquet, but says it was too badly mangled to be preserved.

\section{Order COCCYGES. Cuckoos, ete.}

Suborder Cuculi. Cuckoos, etc.

Family Cuculidak. Cuckoos, Anis, ete.

Subfamily Coccyzinae. Cuckoos.

*387. Coccyzus americanus (Linn.). Yellow-billed Cuckoo.

Coccygus americanus. Cuculus carolinensis. Raincrow.

Geog. Dist.- - The eastern subspecies of the Yellow-billed Cuckoo breeds from Florida, Louisiana and eastern Texas north to New Brunswick, southern Ontario, southern Michigan, central Wisconsin and southern Minnesota; west to South Dakota, 
central Nebraska, Kansas, Indian Territory and Oklahoma. In winter to Costa Riea and the West Indies.

The Yellow-billed Cuckoo is one of the best distributed summer residents in Missouri. It is not partial to any one region, though most numerous in the southeast, where it arrives as early as April 25. For the rest of the state the first week in May is the usual time, though in some years a few have appeared, cven in the northern part of the state, during the last days of April, while in backward seasons none have been seen until the second week in May. By the mieldle of May they become more conspicuous, mating begins and transient visitants swell their numbers for a few days. As they do not eall much during daytime the first few days after arrival, the very first are easily overlooked, but betray their presence by calls before dawn of day. Cuckoos are very retiring during the breeding season until the young are fully fledged, when they lay off their reserve and become familiar visitors to our shade trees, even in frequented streets and gardens. About the middle of september the species is for a few clays more prominent than usual, their numbers being reinforced by guests from farther north, but not many are left after September 25 , though the first week in Oetober is usually the time when the very last ones are noted south of the Missouri River. June 4, 1S81, the writer found within the eity limits of St. Louis an egg of this species in the nest of a Catbird and another egg near by in the nest of a Black-billed Cuckoo. There are some, but not many, instances known of the Ameriean Cuckoo laying in the nests of other birds, as, unlike the European Cuckoo, our Cuckoo makes its own nest, hatehes its own eggs and rears its own young. But the nest of our Cuckoo is such a frail strueture that a strong wind storm will blow it from its support unless the bird be setting. This may happen before the last of the eggs are laid, and the bird being pressed may be foreed to take recourse in other birds' nests. 'Though euckoos' eggs have repeaterily been found in the nests of Robins and Catbirds, also in those of the Thrasher, Woodthrush, Cedarbird, Redbird and Rose-breasted Grosbeak, there is no record of any of those birds having been seen caring for young Cuckoos.

*388. Coccyzus erythrophthalauss (Wils.). Black-billed Cuckoo.

Coccygus erythrophthalmus. Cuculus erythrophthalmus. Raincrow.

Geog. Dist.-Eastern North America, breeding from the mountainous part of Georgia north to Newfoundland and south- 
ern Laborador, and in the west from eastern Texas and Arkansas to western Assiniboia, but more commonly northward, increasing in proportion as the Yellow-billed decreases. In winter, south to the West Indies and northern South America.

In Missouri this species is much less common as a sunmer resident than its cousin, the Yellow-billed Cuckoo, but has been found breeding in small numbers throughout the state except in the low southeast. In the Ozarks it is reported as a breeder as far south as Heburn, Cleburne Co., Ark., by Mr. B. T. Gault in 18s8, and at Eureka Springs by Mr. Philo W. Smith, Jr., in 1906. Both species frequent the same localities and instances of the eggs of one species found in the nest of the other are not very rare, for like the Yellow-billed, it is sometimes compelled to deposit its eggs in other birds' nests, and such eggs have been found in the nests of the Catbird, Wood Pewee and YellowWarbler. It comes to us in spring about the same time as the other speeies, but is apt to loiter a few days longer in the fall, sometimes to the middle of Oetober (Oetober 15, 1899, Keokuk; October 16, 1885, St. Louis).

Suborder Alıyones. Kingfishers.

Family Alcedrnidae. Kingfishers.

*390. Ceryle alcyon (Linn.). Belted Kingfisher.

Alcedo alcyon.

Geog. Dist.-From Panama and the West Indies to the Aretic Ocean. Breeds from southern border of United States northward and winters from the southern United States southward.

The distribution of the Kingfisher as a summer resident in Missouri is as universal as it possibly ean be, and the species may even be called common, because its large size, loud rattle and general habits make it so easily observed and recognized that nobody who has an eye for birds ean overlook it. But, if a census of all birds were taken, we would find that the Kingfisher is not more numerous than some retiring species ordinarily styled rare. Fortunately the cireumstance that it raises a pretty large family prevents a more rapid decline of its numbers, which otherwise would be the inevitable consequenee of the treatment it receives from everyone who carries a gun. In the eyes of the fisherman and hunter, anything that eatches a fish, be it ever so small and worthless, is guilty of a crime that calls 
for capital punishment; and the Kingfisher is such a tempting mark for the tiro who longs to become an expert wing-shot. On the rapidly flowing Ozark streams, especially those flowing southward, the Kingfisher is almost entitled to the rank of permanent resident; farther north a few linger through forewinter until real cold weather sets in; others return with the first thaw, as February 25, 1884, St. Louis; February 26, 1905, Warrensburg; but real spring movement does not begin before from Mareh 10 to 15, and in cold springs a week or two later. Full numbers are not present before the middle of April. Their departure in the fall is equally irregular; some desert their haunts early in October, while others do not think of leaving before the first cold snap comes in the latter part of November.

Order PICI. Woodpeckers, etc.

Family Picidae. Woodpeckers.

392. Campephilus principalis (Linn.). Ivory-billed Woodpecker.

Picus principalis. White-billed Woodpecker.

Geog. Dist.-Formerly South Atlantic and Gulf States north to North Carolina and Maryland; west to Eastern Texas, and in the Mississippi Valley to southern Indiana, Illinois and Missouri. Florida and Louisiana are the only states in which the species has been found within the last ten years.

The last record of its capture in Missouri is November, 1895, when Captain Gillespie of the St. Louis police force brought one home from Stoddard Co., and had it mounted by Mr. Frank Schwarz. It was a male and was killed near the Little River on November 8 by a local hunter, named Spradlin, eight miles southwest of Morley, Scott Co.

\section{*393. Dryobates villosus (Limn.). Hairy Woodpecker.}

Picus villosus.

Geog. Dist.-Of the seven subspecies inhabiting North America, this is the one which elaims the northern and middle portion of the eastern United States as its domain and is found from the Atlantic coast to the Plains, from North Carolina to Nova Scotia and west to Kansas and Nebraska. Non-migratory, except partly in its most northern home. 
In Missouri the Hairy Woodpecker is a fairly common resident, generally distributed, though nowhere numerous. On the breeding grounds it is most conspicuous during the mating or wooing season in early spring, but becomes very secretive and silent when incubation begins and appears then scarcer than it really is. After the young are fully grown and can take care of themselves, the species takes to roaming and visits all kinds of trees and places, even in thickly settled neighborhoods. In winter we sometimes see individuals which strike us as being decidedly larger and whiter than those we are used to seeing; they may be visitors from more northern regions with a tendency to an approach toward the subspecies leucomelas, which inhabits British North America.

*393b. Dryoiates villosus audubonil (Swains.). Southern.

Hairy Woodpecker.

Picus audubonii.

Geog. Dist.- South Atlantic and Gulf States, north to North Carolina, Tennessee, Arkansas, west to southeastern Texas. Non-migratory and much more common than the other form, saicl to be nearly as common in the south as the Downy IIoodpecker is in the North.

In Missouri this small edition of Hairy Woodpeckers, or at least a near approach to it, inhabits the overflow region of the St. Francis and Little Rivers in Dunklin and Pemiskot Counties. To one who is aceustomed to the common Hairy of the middle and northern states, the difference in size and color is striking. Mr. B. T. Gault, who took a specimen in Dunklin Co., in March, 1894, writes: "It compares favorably with the Texas and Florida birds, both in size and markings, with the exception of the bill, which is of the same length as that of the more northern bird (villosus), though not as broad and heavy. With that one exception they might easily be pronouneed as very good specimens of the Southern Hairy W."

*394c. Dryobates pubescens medianus (Swains.). Downy Woodpecker.

Picus pubescens.

Geog. Dist. - Of the six subspecies of Downy Woodpeckers, this is the one which inhabits the Middle and Northern States, as well as the southern provinces of Canada from Newfoundland 
to Alberta. Non-migratory, except farthest north, where partly migratory.

In Missouri it is a common resident in all parts of the state; one of the few species deserving the designation of permanent resident, meaning that the same individuals are found the whole year round at or near the same place, provided that place furnishes food of the right kind and in sufficient quantity in all seasons. In winter it makes regular rounds through its domain, often in company with Tufted Tits, Chickadees and Nuthatches, forming little troops which are sometimes joined by Creepers, Kinglets and Yellow-rumped Warblers. Its resemblanee to the Yellow-bellied Woodpecker in juvenile dress has earned for it, as well as for its cousin, the Hairy, the inappropriate name, Sapsucker, and at the same time the hate of ignorant and intolerant people. This is another and impressive proof of the unreliability of observation on the part of the general public. Superficial resemblance in color and size are sufficient to confound two entirely different birds and to blame an innocent ereature for the inagined wrong-doings of another.

*395. Dryobates borealls (Tieill.). Red-cockated iroodpecker.

Picus borealis. Picus querulus.

Geog. Dist. - South Atlantic and Gulf States to eastern Texas; north to North Carolina, Tennessec, Arkansas and Indian Territory. Non-migratory.

Not found in Missouri as yet, but, being an inhabitant of pine woods, it may occur on the southern slope of the Ozarks in the region of the Short-leafed Yellow Pine (Pinus mitis or echinata), which originally extended from Perry Co. southwestward to Taney Co. At Heber, Cleburne Co., Ark., Mr. B. T. Gault observed it daily in the summer of 1888 in piney woods. Since the above was written, Mr. E. Seymour Woodruff found the Redcockated Woodpecker in Shannon Co., three examples on March 15, 1907, and two on Mareh 30, 1907. On May 5, 1907, he writes that the species is not so uncommon as he at first thought. He says: "I see and hear them constantly, and a female secured on April 19 was in breeding condition." "He again met with several Red-cockated Woodpeckers in Carter Co., near the line of Reynolds Co., May 29, 1907, but says: "I guess the cutting off of the pine will drive them out of the region. I have seen none near Grandin." 
*402. Sphyrapicus varius (Linn.). Yellow-bellied Sapsucker.

Picus varius. Yellow-bellied Woodpecker.

Geog. Dist.-Eastem North America, breeding regularly from Massachusetts, Michigan, Wisconsin, Mimnesota and Manitoba, northward in wooded regions to lat. $61^{\circ}$; south in the Alleghanies to North Carolina and irregulariy to Ohio, Indiana, Illinois, Missouri. Winters from about lat. $40^{\circ}$ southward to the West Indies, Mexico and Costa Rica.

The Sapsucker is best known in Missouri as a spring migrant. During a few favorable nights in early April a whole army, northbound, invades the state and takes possession of it for a few days; every clump of trees, even shade trees and telephone posts in towns, are inferted with them, but if nothing unseasonable happens in the execution of the weather program, the mass disappears as mysteriously as it came. As a winter resident the species is scattered singly or in small troops throughout southem Missouri from the Missouri River bottom southward, but more plentifully in the primeval forests of the southeast. They are mostly birds in juvenile dress and not much is seen of them at this season, even when in our own gardens, drilling holes in pines and sugar maples, because they know how to keep on the other side of the tree and rather try to evade us by remaining quietly where they know they are not seen than by flight. When detected they seek safety by flying to a distant tree, behind which they again hide. Besides pine and maple, there are quite a variety of trees which they like to tap for their sap in early spring, among them apple, hickory, linden, poplar, birch, etc., and though it spoils the appearance of some trees, especially the pine by resin running down their sides, it does not weaken the tree visibly, nor does it detract from its productiveness. In very cold weather they look rather disconsolate and apparently suffer privation; if it lasts long, they disappear, probably go farther south or die. During the latter part of February there is usually a decided relaxation of the rigor of winter and, though no signs of spring may be visible for a whole month, some birds feel an impulse to move in the direction of their summer home, among them some Sapsuckers, appearing in March in localities where they had not wintered. Real migration sets in only during the last week of that month, and, if the weather is not favorable, postponements are in order till early April. After a few days of preliminary action by the vanguard, the bulk, as mentioned above, appears. This general advancement is in 
turn followed by a rearguard of loiterers. As the weather conditions in early spring do not follow any prescribed rules, but on the contrary are subject to great irregularities, considerable variations in the time and length of passage oceur; in some years the last Sapsucker has passed through by the middle of April, in others the bulk does not come before that time and the "lasts" remain to the end of the month and sometimes even into May. Their transit through Missouri in the fall is less conspicuous. The "firsts" are dropping in during the latter part of September, but we are more likely to meet with them early in Oetober, when for a week or two they may be met with most anywhere. Few linger to the end of the month and after the first week in November winter numbers only are with us. From St. Louis northward in the bottoms of the Mississippi flood plain a few breed; Mr. Julius Hurter folind a nest with young near St. Louis, and Mr. E. T. Currier in Clark Co. A suspiciously late date is contributed from Shamnon Co. by Mr. E. S. Woodruff, May 9, 1907, a whole fortnight after the last transient had gone, the transit of the species taking place from March 21 to April 24. Another late record for southern Missouri is one made by the writer at Branson, Taney Co., May 10, 1906.

*405. Ceophloeus pileatus (Linn.). Southern Pileated Woodpecker.

405a. Ceophloeus pileatus abieticola Bangs. Northern Pileated Woodpecker.

Picus pileatus. Hylotomus pilcatus. Cock-of-the-Woods. Log-cock. Black Woodeock.

Geog. Dist.-The former range of the Pileated Woodpecker included all of North America south of the $63^{\circ}$ lat. except the southern Rocky Mountains; at present restricted to the less settled and more heavily wooded districts, and therefore rare in the Eastern States.

Because the average size of the birds from more northern regions is a trifle larger, with the white markings more extended and the black less sooty, more brownish or grayish brown, a new subspecies has been made, habitating from the southern Alleghanies northward. Since Missouri is apparently in the region where the two subspecies merge, a closer study seems 
necessary to tell to which of the two each individual belongs. Fortunately, Pileated Woodpeckers are still found in different parts of the state, more especially in the heavy timber of the southeast. The species is non-migratory, wintering where it occurs. Because generally described as shy and without adaptability to changed conditions of environment, an exceptional case deserves mention, in which a pair accepts the hospitality and protection of a suburban place, that of Dr. A. F. Eimbeck of New Haven, Mo., and continues to raise an interesting family.

*406. Melanerpes erithrocephalus (Linn.). Red-headed

Woodpecker.

Picus erythrocephalus.

Geog. Dist.-Eastern North Amercia, from Gulf of Mexico to southern Ontario and eastern Manitoba, slowly spreading to adjacent districts. West to the eastern slope of the Rocky Mountains (eastern Wyoming and Colorado), straggling westward to Salt Lake Talley and Arizona. Formerly common in Connecticut and Massachusetts, now rare east of Hudson River. Winters chiefly south of latitude $37^{\circ}$, where it remains from the end of September to the end of April, appearing at its most northern habitat late in May and leaving there in August or early September. Quite a number winter in the region between $37^{\circ}$ and $40^{\circ}$, single individuals even farther north in southern Wisconsin, Iowa and Nebraska.

In Missouri the Red-head is one of the best known, most familiar, summer residents in all parts of the state. It is undoubtedly the most numerous member of the family in summer. In traveling through the state we see no bird as often along railroad lines or highways as this strikingly beautiful and confiding friend of man. It likes the deep woods in winter, but in summer it wants to be on open, preferably cultivated, land. When most of the states were covered with tree growth the Redhead's home was on the towering giants with which the woods were richly sprinkled. With the partial clearing of the land it did not disappear from sight, as most woodland birds are bound to do, but on the contrary became for a time more numerous, apparently at least, especially where deadenings existed or trees and stumps were left standing in the field or as bulwarks against the encroachments of the crceks. It seems to be thankful for the 
acts of civilization and not averse to benevolent assimilation. Where its last trees and stumps are removed it takes to telegraph and telephone poles, sometimes much to its undoing, as ignorance aecuses it of weakening the poles and cruel man with no regard for the sanetity of home, plays havoc in an atrocious manner by closing up the hole. When not molested the handsome bird becomes an inmate of our suburban homes, of parks and cemeteries, of every clump of trees about the farms, and even of shade trees in the streets of towns. There are few birds that come with more precision than our Redheads in the spring. As with other summer residents which are in some measure winter residents, the real spring movement of this species is somewhat obscured by individuals which have only temporarily retreated to near-by sheltered bottoms and return with niilder weather, more or less in advance of the masses that have gone farther away and patiently wait till their regular time has come. This is for the whole state between April 20 and 29, when after a few favorable nights their old haunts are resounding with their peculiar calls. They are particularly numerous and noisy during the first half of May, after which they settle down to domestic duties. In July, when the young ones are grown, the species becomes again conspicuous and remains so until the middle of September. Strangely enough they leave us while the land is still flowing with milk and honey for such pretensions as Woodpeckers are supposed to have, but they know a land where beechnuts grow, and there they go. Their departure is as wonderful as their arrival in spring; all at onee they are gone. They seem to go in a body, sometimes even in daytime. Within one hour, 10-11 a. m., September 15, 1S84, I counted 284 flying across the Mississippi River in the southern part of St. Louis, all going the same way, eastward.

This exodus takes place in the third week of september, leaving only those behind which intend to winter. Most of their usual summer haunts are deserted, but exceptions are not rare where solitary birds or a few together are found even in small oak groves all winter in suburbs or villages. Quite different conditions prevail in the heavy timber of the sheltered bottomlands, principally in the southeast. There the Redheads know no season; all winter whole troops of them hammer away on dark and dreary days or frolic when the sun shines. There is no bird more playful than the Redhead. 
*409. Centurus Carolinus (Limn.). Red-bellied Woodpecker.

Picus carolinus. Mclanerpes carolinus.

Geog. Dist.-Eastern United States from Gulf of Mexico to Chesapeake Bay, rarely northward in the Atlantic States to Massachusetts; west of the Alleghanies north to southwestern Ontario, southern Michigan, southern Wiseonsin and southeastern South Dakota; west to eastern Nebraska, central Kansas, Indian Territory and Texas; oceasionally to Colorado. With the exception of the most northern part of this range ehiefly non-migratory, but seldom leaving the woods in winter.

In Missouri a fairly eommon resident in all parts of the state, though more common south and eastward, especially in the river bottoms and the alluvial counties of the southeast.

*412. Colaptes auratus lupeus Bangs. Northern Flicker.

Cuculus auratus. Colaptes auratus. Picus auratus. Yellow-shafted, Yellow-winged or Golden-winged Woodpecker. Pigeon Woodpecker. High-holder. Yellow-hammer.

Geog. Dist.-Like the Pileated Woodpecker the Flicker has been spilt into two subspecies, a northern and a southern, the latter belonging fortunately to the South Atlantic and Gulf States, therefore not concerning us in Missouri. The range of the northern subspecies includes all the rest of eastern and northern North America, west to the foothills of the Rocky Mountains in Colorado and Wyoming. North of the United States it ranges from the Atlantic to the Paeifie and along the Yukon almost to the Bering Strait. South in winter to the Southern States and on the Pacific coast oceasionally to southern California. Though a migratory bird many winter in the Middle States and some even in the Northern States and western Ontario.

In Missouri the Flicker is one of the best known, most eommon and universally distributed summer residents. It has adapted itself to the new conditions of the country to such a degree that it is now found breeding comparatively seldom far away from the seenes of human activity. It is one of our most amusing pets in suburban and country places, pleasing with its varied repertory of ealls and ludicrous gestures, attitudes and manoeuvres during the time of wooing, which is apparently much protracted for the sake of its own and others' amusement. As a winter resident the Flicker may be called fairly common to rare 
as we go from the Missouri River northward, and from fairly common to common as we go southward. Like the Redhead it winters even in places which afford little food and shelter but extends its daily forage to distant feeding grounds. A Flicker which roosted all winter in one of our bird boxes, left it early in the morning, flying straight south as far as the eye could follow. It was never seen during the day but came back to its box every evening before dark. The month of March is the time set for the return of the Flicker to Missouri, but since the inconstancy of March weather is proverbial, it is not surprising to find that this event may take place just as well in the first as in the second, third or fourth week of the month, the records of a long series of years being thus evenly distributed. Large troops of transient visitants, often in company with Robins, pass through between the middle of Mareh and latter part of April, sometimes spending a week or more at the same place awaiting the desired change in the weather. Extended wandering is done at night but local movements are sometimes noticed in daytime. March 23, 1895, I counted one hundred Flickers in as many minutes all following the same route along the bluffs at Creve Coeur Lake, St. Louis Co., in a northeasterly direction. Being very sociable, congenial fellows, they gather in focks very early in autumu. On favorite grounds troops may be met with in August, largely increased by transients in September, but toward the end of the month a sudden decrease is noticeable and by the first of October many of their haunts are deserted and their occurrence slowly approaches the state which we see in winter, though the advent of real winter may yet induce many of the less brave to depart for a milder elime at the last moment.

413. Colaptes cafer collanis (Tigors). Red-shafted Flicker.

Colaptes mexicanus. Colaptes collaris. Picus mexicanus. Colaptes ayresii (Aud.). Colaptes cafer. Colaptes hybridus.

Geog. Dist.- IVestern North America from British Columbia south to Mexico; east to eastern Nebraska and central Kansas; west to the coast ranges of Oregon and Washington and to the Pacifie coast from northern California to Lower California. Hybrid forms are found wherever the two species meet from Alberta and Assiniboia soutllward over the Plains and in migration as far eastward as western Missouri.

Mr. B. F. Bush of Courtney, Mo., writes: "I shot several 
birds on December 29, 1889, of Red-shafted Flicker, a fine inale of which I skinned and preserved. Saw several others on April $1 \overline{7}, 1895$, and have frequently seen the birds since then, but made no more notes or dates."

Order MACROCHIRES. Goatsuckers, Swifts, etc.

Suborder Caprimulgi. Goatsuckers.

Family Caprimulgidae. Goatsuckers.

*416. Antrostonius carolinensis (Gmel.). Chuck-will's-widow. Caprimulgus carolinensis.

Geog. Dist.-Breeds in Southern United States north to southern Virginia, West Virginia, Kentucky, southwestern Indiana, southern Illinois, southern Missouri, rarely to Kansas; west to southwestern Texas. In winter to the West Indies and through eastern Mexico to South America.

In Missouri a fairly common summer resident from Perry Co. southwestward along the southern slope of the Ozark Mountains from the latter part of April to the end of September.

\section{*417. Antrostonus vociferus (Wils.). Whip-poor-will. \\ Caprimulgus vociferus.}

Geog. Dist.-Eastern North America from the Atlantic to the Plains, north to the southern provinces of Canada, west to Manitoba, Dakotas, central Nebraska, rarely to Kansas. Breeds from northwestern Louisiana and Florida northward and winters from Florida southward to Guatemala.

In Missouri the Whip-poor-will is a well-known summer resident in most parts of the state. It is most numerous on the northern slope of the Ozarks inhabiting the densely scrub-oak covered hillsides, its ideal home site. Next to this most favored territory it chooses the rocky parts of the Ozark border region and the wooded river bluffs of central and northern Missouri. On the southern slope of the Ozarks it is generally replaced by the Chuck-will's-widow, but in many localities both species occur together, coming into towns together to perform their noisy serenades alternately or ensemble. These performances become shorter and less and less regular in June and cease entirely in July but are sometimes heard again in late August or September. 
'Their general departure is taken in September, but occasionally we meet one in early October, up to the 10th of that month. In migration queer places are sometimes resorted to for a day's rest, as for instance a brushy sinkhole by the side of a frequented street in a suburb of St. Louis, April 8, 1899. In the southern half of the state the first Whip-poor-wills are heard in the first half of April, in the northern between the tenth and last of the month. Eggs have been found in St. Louis county, April 24, but cool weather retards laying until May. From many suitable patches of woodland the species has disappeared, or visits them in migration only, because driven away by pasturing animals, too many of which are kept on a small area, devastating the underbrush and tramping everything under feet. Where hogs are kept no ground-builder can long survive as they destroy both eggs and unfledged young and are in this respect as bad as, or worse than, cats or dogs. In the low southeastcrn counties, where that part of the area not subject to yearly imundation is now given up to agriculture, the Whip-poor-will is only an occasional transient visitant as it is in most of the woodland in the flood-plains of the large rivers.

*418. Phalaenoptilus nettaliti (Aud.). Poor-will.

Caprimulgus nuttallii. Antrostomus nuttallii. Nuttall's Whip-poor-will.

Geog. Dist.-Western United States, east to southeastern Dakota, castern Nebaska and eastern Kansas; north to central Idaho and Montana, also to interior of Britisin Columbia, west to Cascades and Sierra Nevada. In winter south from southern border of United States to Guatemala.

In Missouri found by Mr. H. Nehrling in Lawrence Co. in 1885 and probably a rare summer resident in western Missouri, as he heard its call regularly in May and June. Mr. B. F. Bush also heard the bird in McDonald and Barry Counties and thinks it must breed there. Eggs were taken June 1, 1886, at Richmond, Kansas., within 35 miles of the state line.

[418a. Phalaenoptilus nu'rtallit nitidus Brewst, Frosted Poor-will.]

Geog. Dist.-Texas to Arizona; north to Kansas; south to Mexico.

A female shot by Col. N. S. Goss September 23, 1881, at Neosho Falls, Kan., 35 miles west of Missouri has been identified as be- 
longing to this subspecies. Since the geographic distribution of the Poor-wills does not seem to be definitcly established, it will be well to examine carefully every specimen taken in Missouri.

*420. Chordeiles virginianus (Gmel.). Nighthawk.

Caprimulgus virginianus. Caprimulgus popetue. Chordeiles popetue. Bullbat. Mosquito Hawk.

Geog. Dist.-Breeds in the eastern United States from Gulf coast northward, chiefly north of lat. $35^{\circ}$; west to the Plains. North of the United States from the Atlantic to the Pacific, north to Hudson Bay and Mackenzie River, and in wooded districts of the western United States south to northern California. Winters from the Bahamas and Centrál America to the Argentine Republic.

In Missouri a common transient visitant in all parts of the state, but not at all common as a summer resident except in towns and eities where it lays its eggs and rears its young undisturbed on gravel roofs of the highest buildings. It also breeds on cliffs and bluffs along the large rivers and on ridges of the Ozarks, but seems to have been driven from the prairie region. Quiet during breeding time it becomes noisy early in July when, joined by its still more vociferous offspring, it attracts general attention to its wonderful aerial evolutions and gives the city people opportunity for admiration until migration begins in August. The spirit of unrest seems to seize it early in August when it deserts its breeding haunts in the city to go hunting over lakes and rivers, fields and meadows, along the edge of woods and in the clearings, and it soon becomes evident that migration from the north has commenced. The bulk of the transient visitants passes through Missouri between August 25 and September 25 when considerable numbers may be seen in large loose troops anywhere in the state, but no such imposing sights have been enjoyed during the last ten years as formerly, when in the face of on-coming thunderstorms hundreds, yes thousands, of these swift and graceful flyers were speeding southward in dense flocks. Recommended in newspapers by the sporting editor as delicious game the Bull-bats have been the target of our hunting fraternity for years, but the new game law of 1905 does not consider Bullbats as legitimate game, and it is to be hoped the destruction of this useful bird will cease. In spite of their rapid and unsteady flight large numbers are maimed or killed, because, unmindful 
of the continual reports of guns, they persist in beating up and down the same path of a rich hunting field, on a lake or on the shores of a river. As a mosquito and gnat eatcher it has no equal, devouring them in enormous quantities. Though getting scarce during the last days of September, loiteres are always met with in the first week of October, sometimes to the end of the seeond week. In spring the Nighthawk does not play such a prominent part as in autumn migration. The species never becomes common before early May, though the first may chance to be noted any day after the $22 \mathrm{~d}$ of April in the southern and the 27th in the more northern parts of the state. The transit of northbound Nighthawks is distributed over the whole month of May and has on special occasions been observed taking place in very large flocks, as on May 25, 26 and 27, 1882, at St. Louis. Usually the passage escapes notice, because performed in fine weather at great height. Following once with my field glass a hawk, soaring high above, my field of vision was crossed by Nighthawks, which proved to be a part of an extended flight utterly invisible to the naked eye.

[420a. Chordeiles virginlanus henryi (Cass.). Western

Nighthawk.

Chordeiles henryi.

Geog. Dist.--Western North America north to southeru British Columbia, Alberta and throughout Assiniboia, breeding in the United States from western Kansas and western Nebraska and southeastern Dakota to the desert region of southeastern California; winters in northern South America. In migration casual to Wisconsin and Illinois.

Captain Bendire writes: "The eastern limits of its range extend well into Minnesota, Iowa, northern and central Hllinois, where it is the prevailing form found throughout the prairie regions of these states." Mr. Chas. K. Worthen of Warsaw, Ill., opposite the northeast corner of Missouri, writes, that he has taken repeatedly some seasons, and he regards it as a not very uncommon transient visitant.

[420c. Chordeiles virginianus sennetti (Coles). Sennett's Nighthawk.]

Geog. Dist.--Treeless region from the Saskatchewan to Texas. Has been taken near Boone in central, and at Sioux City and 
in Monona Co., western Iowa, and is therefore likely to oeeur in the prairie part of Missouri. Mrs. V. Bailey writes: "Though lighter than virginianus, henryi is mueh darker than sennetti, which is light brown, buffy, and on wing coverts mainly whitish." Also: "top of head brownish instead of blackish, wing eoverts largely whitish, under parts with dark bar's brown instead of black, spaced with white instead of buffy."

Suborder Cypseli. Swifts.

Family Mrcropodidae. Swifts.

Subfamily Chaeturinae. Spine-tailed Swifts.

*423. Chatetura pelagica (Linn.). Chimney Swift.

Hirundo pelasgia. Cypselus pelasgia. Chaetura pelasgia. Chimney Swallow.

Geog. Dist.-Breeds in Eastern North Ameriea from Florida to Labrador and Manitoba; west to eastern Nebraska and Kansas, extending its range with settlements westward. In winter to Gulf of Campeachy.

In Missouri the Chimney Swift is a very eommon summer resident wherever there are chimneys for it to use; it is most abundant in towns and villages, espeeially old settlements along rivers, but deserts the densely built-up parts of the largest cities. There is no doubt that the Swifts of Missouri outnumber by far all the species of swallows taken together, beeause their distribution is not local but universal. Where no ehimney but aecess to the attie or an outbuilding can be had, they find such places to their liking and stiek their nests to rough boards, sometimes several in elose proxinity, but never one below another. In the region of the Water Tupelo, the trunks of whieh are sometimes hollow from top to bottom with large opening on top, the Swifts still observe the custom of former ages, using them for roosts and nests; but such eases will become rarer now as did the use of the hollow Sycamores in the river bottoms a generation ago. The Swift has profited more than any other species of birds by the change which civilization has brought about, and it was, indeed, a fortunate and momentous event when its aneestor's for the first time dared to enter and nest in the ehimneys of the early settlers. Though places more or less suitable for nests may not have been very rare before the advent of the white 
man, no hollow trees ean have afforded the security which an unused chimney of a dwelling gives, inacressible as it is to nearly all the former enemies in the woods. It is this abundance of safe nesting sites which accounts for the enormous increase of Swifts since they became Chimney Swifts, and which allows of a steadily growing extension of their breeding range into formerly uninhabited regions. With his rare gift of daring, which enables the Swift to penetrate deep into the chimneys of occupied houses, he couples a great amount of sagacious eaution as shown when placing his nest into chimneys which he has reason to believe will be used occasionally. I have repeatedly found nests placed a short distance below the mouth of the stove pipe, though eight and more feet from the mouth of the chimney, an expedient of great advantage in case of a short period of unseasonable fires in the stove. The first Swifts of the season reach Missouri in the southeast in the last days of March (March 28, Butler Co.) and St. Louis a week later (April 2, 1888, April 3, 1887, earliest record March 31, 1885), but these forerumners are so few that the best, perhaps the only, way to find them is to wateh in the evening one of their chimneys used for common roost. We have records of their arrival during the first week of April not only from St. Lonis, but repeatedly from Fayette and once even fron Keokuk (April 7, 1897), but the Swifts are not generally seen before the second week and become common only after the middle of the month, usually during the third week. From April 20 to May 20 the common roost is not only used by the Swifts of the neighborhood, but also by varying numbers of transient visitants exceeding many times that of the summer residents. By May 20 the rush of north-bound guests suddenly subsides, but stragglers continue to the end of the month. May and early June, the time of mating and wooing and noisy excitement, and of the presence of troops of transients, is the time when they are most conspicuous contributors to the animation of our landscape. When incubation begins the Swifts, seen before always flying noisily in twos or threes or little troops, all at once fly singly and in silence. This period lasts until the end of July or into August, when the young are on the wing and noise and bustle begin anew, kept up chiefly by the youngsters, which are at this time of the year easily distinguished from their parents by the perfect, unbroken outline of their pointed, long, strongly curved wings, while the parents show decided signs of wear and moult, having shed certain of the primaries. As the 
young can not catch sufficient food and still need the help of the parents for several days after being on the wing, they return to the paternal home sometimes during the day and surely in the evening. After they have become entirely independent, the whole family usually quits the nest chimmey and betakes itself to the common roost. There the attendance increases steadily during August and, since it is also used by transients, reaches its maximum in September, when great variations occur, showing the coming and going of the guests. These have also been seen using the chimney for resting in daytime, entering at six in the morning and reappearing at three in the afternoon, thus explaining a remarkable scareity of the species at certain times of the day. The species remains with us in goodly numbers through the first week of October, usually one of much sunshine and an abundance of winged insects, but becomes very rare during the second week, except sometimes at the common roost in the evening. Dates of "last scen" vary during ten year's observation by Mr. Currier at Keokuk from October 2 to 18, mostly between 10 and 13, and at St. Louis from October 12 to 24, mostly between 14 and 19 .

Suborder Trochili. Hummingbirds.

Family Trochilidat. Hummingbirds.

*428. Trochilus colubris Linn. Ruby-throated Hummingbird. Mellisuga colubris.

Geog. Dist.-Breeding from the Gulf coast to Labrador, west to Alberta, North Dakota, eastern Nebraska, and Kansas. Winters from southern Florida to Cuba, Mexico and Central America.

In Missouri a common summer resident in all parts, but most numerous in the Ozarks and in the bluff region of the large rivers. In Pemiscot Co. the first male Hummer of the season was seen as early as April 11, 1893, the early-flowering Red Shrub Buckeye being the main attraction in the southeast. In the neighborhood of St. Louis the first Hummer should be looked for about the early blossoms of the Tree Buckeye between April 22 and 28, though in cool springs sometimes not before from May 1 to 5 . The first week of May is the time when the van of the species can be expected in most parts of the state. At St. Louis males do 
not become common before the 5th, females not before the 12th of May, when mating begins at once and the peculiar pendulum movement of the courting male may be observed. Transient visitants are sometimes found in small flocks, less often in spring than in autumn, when a dozen or more are seen seattered over a garden where flowers abound. In such places they are conspicuous frequenters from August to early October or until frost kills their favorite Scarlet Sage, often in the second week of the month, but loiterers have been reported much later, as October 20, St. Louis; October 23, 1903, Keokuk; October 18, 1903 and November 2, 1902, New Haven (Dr. Eimbeck).

\section{Order PASSERES. Perching Birds.}

Suborder Clamatores. Songless Perching Birds.

Family Trrannidae. Tyrant Flycatchers.

[443. Muscivora Forficata (Gmel.). Scissor-tailed Flycatcher.]

Muscicapa forficata. Tyrannus forficatus. Milvulus forficatus. Swallowtailed Flycatcher. Bird of Paradise (Texas).

Geog. Dist.-Breeds in southern Kansas, Indian Territory, Oklahoma and Texas. Migrates through eastern Mexico to Costa Rica. Accidental in southern Florida, Louisiana, New Jersey, New England, Nebraska, Manitoba and Hudson Bay region.

Books mention southwest Missouri among the breeding localities of this species, but there seems to be no authentic record of its occurrence in the state, though it is very probable that the Scissor-tailed Flycatcher was once a rare breeder in Missouri. There is a record of its breeding within 60 miles of the western state line, May 13, 1875, at Neodesha, Kan.

*444. Tyrannus tyrannus (Linn.). Kingbird.

Lanius tyrannus. Muscicapa tyrannus. Tyrannus carolinensis. Bee Martin.

Geog. Dist.-Breeds throughout the Eastern United States to the foothills of Colorado; west through Utah, Wyoming and Montana to Nevada, California, Oregon and Washington. In British America from Newfoundland to British Columbia, north through the southern provinces to lat. $57^{\circ}$ in Athabasca 
and the interior of British Columbia. Winters in Central and South America.

In Missouri the Kingbird is one of the most common and best known summer residents on cultivated land throughout the prairie and Ozark bordel region, but much less common in the Ozarks, where chieffy near towns or farmhouses. The first arrive in the more southern part of the state in the second week of April, exceptionally even in the central part (Festus, Jefferson Co, April 7 and 10; St. Louis, April 10 and 14), where they are generally not seen before the third week. In northern Missouri the first come pretty regularly during the fourth week of the month or a few days later, seldom earlier. The bulk of the species does not come before the last days of April in the southern, and the first week of May in the northern part. Transients are present until after the middle of May, sometimes in troops of from 20 to 30, resembling Robins somewhat when on wing, or sitting dismally on fences along the roads, when kept back by unseasonable weather. After getting through with their household duties they withdraw from the breeding grounds, much like the Martins, and, like them, flock in the evening to common roosts, preferably willow thickets along water courses. Many of their haunts are deserted in July, others in August, when the distribution becomes local and changeable, which means that migration has begun and our own King birds are joined by others, themselves departing and being replaced by others, until in the third week of September the last are leaving the state. The last date in eight years at Keokuk, according to observations of Mr. E. S. Currier, is September 10, 1893; at St. Louis, September 12, 1905; at Mt. Carmel, September 17, 1885; at Monteer, Shannon Co., September 20, 1903, and at New Haven, October 1, 1902, and October 4, 1903; these latter dates exceptionally late.

\section{Trrannus verticalis Say. Arkansas Kingbird. Muscicapa verticalis.}

Geog. Dist.--Western North America; breeding from 100th meridian westward to the Pacific; north to Assiniboia, Alberta and British Columbia; south through Lower California and western Mexico to Guatemala in winter. In migration to southeastern South Dakota and eastern Nebraska. As a straggler it has occurred in Iowa, Wisconsin, Maine, New York, New Jersey, Maryland, etc. 
The only available records of its occurrence in Missouri are supplied by Mr. Thaddeus Surber, who took one specimen at Stotesbury, Vernon Co., April 15, 1894, and by Mr. H. Nehrling, who met with the species at Freistatt, Lawrence Co., in the early eighties and considered it fairly common.

\section{*452. Mriarchus crinitus (Linn.). Crested Flycateher.}

Muscicapa crinita. Tyrannus crinitus. Great Crested Flycatcher.

Geog. Dist.-Eastern North America, north to New Brunswick, southern Quebee, Ontario and eastern Manitoba; west to Minnesota, eastern Nebraska, Kansas, Indian Territory and southwestern Texas. Migrates through eastern Mexico to Costa Rica, Panama and Columbia.

In Missouri a common summer resident in all parts of the state. Originally a denizen of the forest it is changing its habits to conform with the state of eivilization and is taking up its abode in parks, cemeteries, groves, wood patehes, orchards and even in the shade trees of villages and suburbs. Where suitable bird boxes are put up, it aecepts them for nesting sites, and when the indispensable snake skin is wanting it uses paraffine or tissue paper to eover its eggs during a temporary absence. The return from winter quarters takes place with great regularity during the fourth week of April, seldom delayed to the first week in May, when the speeies is usually in full numbers and very noisy. It departs in fall during the first half of September, the last being noticed about September 20 (September 21, 1885 and 1887, St. Louis).

*456. Sayonnis phoebe (Linn.). Phoebe.

Muscicapa phoebe. Muscicapa fusca. Tyrannus fuscus. MIuscicapa atra. Tyrannula or Muscicapa nunciola. Sayornis fuscus. Bridge-pewee. Phoebe-bird.

Geog. Dist.-From eastern Mexico and Cuba north through Eastern United States to Newfoundland and the southem provinces of Canada, in the interior to $56^{\circ} 30^{\prime}$ lat.; west to Alberta and in the United States to eastern Nebraska, eastern Kansas, rarely to Wyoming and Colorado. Breeds from South Carolina and Arkansas northward and winters from the South Atlantic and Gulf States southward.

In Missouri a fairly common summer resident, breeding in all parts of the state, as far south as the southern border, but more 
common northward. In the more southern part of the state the first Phoebes are heard in the last week of February, not only in the southeast, but also in the Ozarks (February 28, 1903, Salem, Dent Co., Mr. F. C. Pellet) (February 29, 1904, Monteer, Shannon Co., Mr. W. G. Savage). In the neighborhood of St. Louis the earliest males arrive on their accustomed stands during the first week of March, but often bad weather makes them very miserable and they have to wait from three to six and more days for their mates to join them, so that it is usually not far from the middle of March before the species becomes readily observable in its old haunts. In exceptionally inclement March weather as in 1906 the Phoebe can not be expected before April, when, in ordinary seasons, it is laying eggs (first egg March 31, 1903, Montgomery City; April 1, 1904, St. Louis). North of latitude $39^{\circ}$ the absence of uniformity in our March weather is clearly reflected in the great diversity in the dates of first arrivals, varying at Keokuk between March 6, 1894, and April 2, 1895, in a series of observations during thirteen years (1892 to 1904 incl.) by Mr. E. S. Currier. Mostly silent and retiring in autumn, their departure is not so easily noticed as their arrival in spring, which they announce loudly and with much constancy for hours at a time. Temporary conspicuousness is observable on fine October days, which probably means the presence of transient visitant resting only for a day or two. The last are noted during the second half of October, even in the more southern part of the state. Latest for Keokuk, October 16, 1900; for St. Louis, October 27, 1885.

\section{Sayornis saya (Bonap.). Say's Phoebe.}

Muscicapa saya. Sayornis sayus.

Geog. Dist.-Western United States from the Pacific to the Plains, and from southern Mexico to the Aretic circle. Common in western Kansas, Nebraska and the Dakotas. Said to extend its range eastward.

Was reported once from Butler, Bates Co., by Mr. Harvey Clark in 1886, and has occurred in southeastern Nebraska, Iowa, Wisconsin and Illinois as an accidental visitor.

459. Nuttallornis Borealis (Swains.). Olive-sided Flycatcher.

Tyrannus borealis. Contopus borealis.

Geog. Dist.-Breeds from the mountains and northern parts of the United States north to Athabaska and southern Keewatin, 
and from Nova Scotia to the Pacific. In winter to Central and northern South America as far as Peru.

In Missouri an irregularly, or fairly, common transient visitant from the second week of May to the first of June (June 2, 1907, St. Louis) and in fall from August 20 to the middle of September. Most of the notes on this species have been made on the bluffs and in the bottoms along the Mississippi River, but it has also been met with in the southeast on the St. Francis River, in the Ozarks at Galena, Stone Co., and has been reported from the western border, Jasper Co., by Mr. Savage. To one who is familiar with its habit of perching on the highest tree tops, or who is aequainted with its peculiar, far-reaching whist'e, its presence cannot easily escape notice especially in spring when, retained by cold nights or strong northerly winds, it remains at the same place several days. Its stops in autumn seem to be shorter and less observable, because so early in the season, when the trees are yet covered with foliage and insects most plentiful.

*461 Contopus virens (Linn.). Wood Pewee.

II uscicapa vircns. Muscicapa rapax. Muscicapa querula. Tyrannula virens.

Geog. Dist.-Eastern North America; breeds from the Gulf coast to Newfoundland and southern Canada; west to Manitoba, eastern Nebraska, eastern Kansas, and Texas south to the mountains of Orizaba. In winter through eastern Mexico and Honduras to Columbia and Ecuador.

In Missouri one of the common and most generally distributed birds in all kinds of woods, high and low, dry and wet, and, where these are wanting, resorting to orchards, parks, cemeteries and the larger gardens in towns and suburbs. The first Wood Pewees arrive in southeast Missouri as early as April 20, in central Missouri April 28, and in the northern tier of counties between the 4 th and the 12th of May. 'They leave the state in the latter part of September, but stragglers linger into October and the last depart between October 8 and 15. Transient visitants, indicated by the presence of unusually large numbers, have been noticed about the middle of May and in the fourth week of September. Though the forerunners reach St. Louis at the end of April, the species does not become common and generally distributed before the fifth of May and in the more northern part of the state before the middle of the month. 
463. Empidonax rlaviventris Baird. Yellow-bellied Flycatcher.

Tyrannula flavirentris.

Geog. Dist.-Eastern North America; breeds from Massactusetts northward to Newfoundland and southern Labrador, and west through densely forested regions to Manitoba. In winter through eastern Mexico to Panama.

In eastern Missouri a fairly common transient visitant from May 5 to June 1 (exceptionally later, as in 1907 to June 4) and from August 25 to September 20. There is only one record from western Missouri, that of W. E. D. Scott, who took a specimen at Warrensburg, May 18, 1874. All other observations on the species were made along the eastern edge of the state from Keokuk to the southern state line and in the southeast west to Carter Co., where Mr. E. S. Woodruff took a specimen at Grandin, May 16, 1907. The fact that it has not been reported from other localities is no proof that it does not oceur, but the species easily eludes detection, being late in transit when vegetation is already luxuriant and confining itself to dense shrubbery. It is most commonly found in low situations, willow thickets in the flood plains and shrubbery along creeks of the bluff region, but in the height of migration it is of ten found in parks and gardens, orchards and hedge-rows. Although usually silent, its peculiar call-note, different from those of the other eastern members of the genus, is sometimes heard toward the end of its stay.

*465. Empidonax virescens (Vieill.). Green-crested Flycatcher.

Empidonax acadicus. Muscicapa querula. Tyrannus acadicus. Acadian Flycatcher.

Geog. Dist.- Eastern United States, north to southern New York and southern Michigan; west to Nebraska, eastern Kansas and Texas. Winters in Central America, Cuba and Yucatan.

In Missouri a common and generally distributed summer resident from April 28 to September 25. Of the four species of this genus occurring in Missouri this is by far the most common, because found in all parts of the state wherever the axe has spared enough trees to leave at least a semblance of a forest. Unlike its relatives, the Wood Pewee and Great Crested, the Acadian has not yet learned to feel at home anywhere else but in the forest itself and, if it does not yield soon, general defor- 
estation will be the death-blow to this and a number of other woodland species equally obdurate and inaccessible to civilization.

*466. Empidonax traillil Aud.. Traill's Flycatcher.

Muscicapa traillii. Empidonax pusillus traillii. Empidonax pusillus. Little Flycatcher.

Geog. Dist.--Western North America from Ohio, Illinois and Michigan to the Pacific, and from Sitka and the Mackenzie River south into Mexico. Winters south of the United States.

As a fairly common summer resident the Traill's Flycatcher has a peculiar distribution in Missouri. It inhabits the entire prairie region of northern and western Missouri, enters the Ozark border subregion in Newton, Lawrence and Greene counties, and follows the Mississipp: River flood plain south at least as far as Ste. Genevieve Co. It is not found in the Ozarks nor in the lowland of the southeast. In the vicinity of St. Louis it arrives with great regularity on the fourth or fifth day of May, seldom earlicr (April 29, 1884). At Keokuk, May 11, 1902 (Currier). It is still numerous in the second week of September, probably joined by transients, but disappears about September 25, rarely later (October 4, 1905, St. Louis). Its original haunts are the trees bordering rivers, creeks and lakes, or clumps of willows in swampy places, but being a quick and wide-awake bird it was not slow in accommodating itself to human surroundings and is now at home in city parks and cemeteries, in orchards and the fringe of trees and shrubs along frequented country roads. One would expect to find a species with such a happy adaptive faculty spreading rapidly with deforestation and cultivation, but this has not been the case during the past twenty-five years and there is no visible increase in their numbers. The only explanation for this is the careless manner in which they place their nests in exposed positions with no thought of concealment, and the lateness of their nesting, which does not allow a second attempt when the first has been unsuccessful.

466a. Empidonax traillit alnorum Brewst. Alder Flycatcher. Empidonax pusillus traillii. Empuilonax traillii. Tyrannus trailli.

Geog. Dist. - Eastern North America from New England and Newfoundland to Alaska, and in the United States found as far west as western Nebraska. Winters in Central America. 
There is little doubt that this subspecies occurs in our state in its passage from summer to winter quarter's and vice versa, but it remains to be shown to what extent, since the two subspecies cannot be distinguished with certainty without the use of compasses. Since the above was written Mr. E. S. Woodruff captured a female Flycatcher at Grandin, Carter Co., which Dr. J. A. Allen and Dr. Jno. Dwight identified as belonging to this subspecies.

467. Empidonax minimes Baird. Least Flycatcher.

Tyrannula minima. Chebeck.

Geog. Dist.-Eastern North America, west to Colorado, Utah, Wyoming, Montana and Alberta; north to Newfoundland, Oxford Lake, Keewatin and Fort Simpson, Mackenzie. Breeds from North Carolina, northern Ohio and Indiana, Nebraska and Wyoming northward. Winters in Central America and Panama.

In Missouri a fairly common transient visitant from April 28 to the third, seldom to the fourth, week of May (June 3, 1907, St. Louis). A few days earlier in the south (Shannon Co., April 24, 1904, W. G. Savage); a few days later in the north (April 28 to May 5, Keokuk, E. S. Currier). In fall migration from August 24 to the middle of October (October 14, 1885, St. Louis; October 20, 1902, Jasper Co., Sarage). As Mr. Chas. $\mathrm{K}$. Worthen has taken this species during the breeding season at Warsaw, Ill., it may be found to be a rare breeder in the most northern part of Missouri. Mr. T. M. Trippe mentions it as breeding in large numbers in Mahasca Co., Iowa, in 1872.

Suborder Oscines. Song Birds.

Family Alaudidae. Larks.

474. OtOCORIS AlPEstris (Linn.). Horned Lark.

Alauda alpestris. Eremophila alpestris. Alauda cornuta. Eremophila cornuta. Shore Lark. Snow Lark.

Geog. Dist.-Northeastern North America, Greenland and Old World. In winter south in United States to the Carolinas, Illinois, Iowa, Nebraska.

The status of the different kinds of Horned Larks found in Missouri in winter needs further investigation and corroboration of the statement that this subspecies is a winter visitant in the 
state. Flocks of Horned Larks seen in winter on the sand bars of the Mississippi opposite St. Louis were apparently of this larger and darker form. Mr. E. S. Currier says that it appears in December at Keokuk and is seen off and on until early February and that the Prairie Horned Lark seems to be absent or searce during that period. Mr. Sidney S. Wilson gives me the following dates for this subspecies at St. Joseph: February 22, 1896, twenty; February 15, again seen; February 21, bulk present; April 4, last; adding that there were a few Prairie Horned Larks with them.

*474b. Otocoris alpestris praticola Hensh. Prairie Horned Lark.

Eremophila alpestris praticola. Prairie Lark. Horned Lark.

Geog. Dist.-Breeds from eastern Kansas, eastern Nebraska and Manitoba eastward to New England and eastern Quebec. In winter withdrawing from northern regions, and extending its range to Texas, Louisiana, South Carolina, ete.

In Missouri a fairly common resident in all parts on cultivated ground, high and low, not only in the prairie and Ozark border region, but in the cleared tracts of the Ozarks themselves and in the marshes of the flood plains of the large rivers. Small troops, sometimes in company with Lapland Longspurs, wander about in search of food, resorting to the bare wind-swept hillsides when the ground elsewhere is covered with snow. When the snow becomes too deep, or when sleet and ice crusts bury everything, hunger drives them to the farms and highways which they follow into villages, towns and cities. They are most conspicuous late in February and Mareh, their time of mating and nestbuilding, when their queer song is in the air for many minutes at a time, and again when the youngsters are brought to the country roads and are taught the advantages of the dust bath.

[474.k. Otocoris alpestris hoyti Bishop. Hoyt's Horned Lark.]

Geog. Dist.--Breeds from. Hudson Bay to the Mackenzie River and south to Lake Athabasca. Migrates to Nevada, Utah, Kansas, Nebraska, Wisconsin, Iowa, Michigan, casually to Ohio and New York.

As this lately separated large pale subspecies has been taken at different places in eastern Nebraska, it may be presumed that 
it also visits our state in winter and should be looked for especially in the northwesern part.

Family Convidae. Crows, Jays, Magpies, etc.

Subfamily Garrulinae. Nagpies and Jays.

475. Pica Pica hudsonica (Sab.). American Magpie.

Corvus pica. Pica hudsonica. Pica melanoleuca. Pica caudatahudsonica.

Geog. Dist.--Western and northern North Anerica; east to Lake Winnipeg, western Nebraska and eastern Colorado; west to the Cascade Mountains; in the north through western Assiniboa, Alberta and British Columbia to Alaska; south to western Texas, New Mexico and Arizona. Non-migratory, except in the far North. Formerly in winter to Kansas, eastern Nebraska, Iowa, Wisconsin, Michigan and Ontario, but range and numbers are greatly reduced through constant persecution by hunters and ranchmen who consider them a nuisance.

There is a record by L. W. Corder of Waverly, Mo., one of the observers of bird migration, in his report to the Department of Agriculture, stating that he saw four Magpies November 1, 1890, in Saline Co., Mo. Indications are not wanting that Magpies formerly extended their wanderings, at least in some winters, as far south as Missouri. Mr. Heiser of Keokuk has a mounted specinen which he shot many years ago in winter near the Des Moines River not far from the state line. Audubon mentions in his journal two caged Magpies at Fort Croghan, near the present site of Omaha, May 10, 1843, said to have been caught in nooses by the legs. In 1885, Mr. G. S. Agersborg of Alda, southeastern South Dakota, writes (Auk vol. 2, p. 282): "This bird, which was formerly very common here in winter, frequenting trappers' camps and farmyards, has within the last four years entirely disappeared." It is said to have been taken in Shawnee Co., eastern Kansas, in October (Snow, 1873).

*477. Cranocitta cristata (Linn.). Blue Jay.

Corvus cristatus. Garrulus cristatus. Cyanurus cristatus. Jay Bird.

Geog. Dist.-Eastern North America to western Nebraska and western Manitoba, and from the Gulf to Newfoundland and Hudson Bay; northwestward to Athabasca River and Alberta. Winters from the Northwest Territories and Cape 
Breton Island southward to the Gulf eoast, but most of them withdraw from our northern states and even from Missouri.

A eommon summer resident in all parts of Missouri, more abundant in villages and towns than in the forest. Also a fairly common winter resident, and a very numerous transient visitant in spring and fall. The regular passage through our state of large numbers of Blue Jays from summer to winter quarters and vice versa is of special interest, because performed in daytime, showing us how land birds wander. Contrary to some theories these Blue Jays do not follow eertain highways, as for instanee the flood plain of the Mississippi River, but many minor routes amounting almost to a broad front. It is true that many floeks follow each other over the very same ground, resting on the same trees and erossing the Missouri River at the very same point, but there are such routes in every eounty of the state. The route along the Mississippi River bluffs and bottom may be one of the most frequented, but routes do not neeessarily follow any river and lead straight across the hills of the Ozarks. The migration of northbound Blue Jays begins in some years as early as April 11, but usually after the 20th and beeomes brisk toward the end of the month, continuing through the first week of May, but ceases after the 10th or 12th of the month. At this time even the last of our own bircls, those of the seeond year, are paired and building.

In fall south bound flocks pass from the beginning of the fourth week in September to the middle of Oetober. Flocks are of variable size, from 20 to 60 birds, and are on wing ehiefly in the forenoon between eight and eleven, in spring between six and ten, less often in the afternoon between three and five. They are perfeetly silent when flying, but when alighting are greeted by our resident Blue Jays, and a great noise results. Though only a small pereentage of our summer residents are true permanent residents, those that have spent the winter away from home have all returned before the last northerners pass through. Blue Jays eannot stand mueh zero and below zero weather; they freeze the toes badly in severe winters, learning thereby a lesson whieh they bear well in mind the following fall, leaving early. The more cxposed woods are largely deserted when the trees are bare early in November and do not beeome populated again before the winter is over. This is indeed a very unstable time, oscillating between the middle of February and the middle of April. After an unusually eold late winter, as that of 
1906, when we had the coldest March in history with an average temperature of $33^{\circ}$, i. e., ten degrees below the lowest average in thirty years, Blue Jays did not become common at their breeding stands before the middle of April. In exceptionally mild winters old pairs have announced their return in the middle of February. In ordinary seasons the first nests are finished early in April and when the northern transients and birds of the second year appear on the scene, our birds, occupied with domestic duties and therefore quiet and retiring, contrast sharply with the bustling, restless troops. In June and early July we sometimes see them feed grown young and build again at the same time, which means that they intend to breed a second time. By the middle of July the birds of the first brood are fully grown and have begun to play a conspicuous part as noise makers in the otherwise quiet woods. Throughout August and September to the middle of October there is no species of birds more proninent, oftener seen or heard, than the Blue Jay. After September 21 , they are more restless than before and it becomes evicient that some change is going on; some days they are quiet and few, then again noisy and numerous. After the first of November we have to go to the sheltered river bottoms and to the heavily wooded southeast, if we want to see them in larger numbers or noisy troops; those that stay near their breeding grounds are then quiet and circumspect, though for reasons of security and provender frequenting the environs of human habitations and therefore appearing more numerous than they really are.

\section{Subfamily Corvidae. Crows.}

*486. Corvus corax sinuatus (Wagl.). American Raven.

Corvus sinuatus. Corvus cacalotl. Corvus corax. Corvus carnivorus. Mexican Raven.

Geog. Dist.-Western United States, Mexico, Guatemala, northern Honduras; east to southern Indiana, southern Illinois, Missouri, Nebraska, Kansas, Wyoming and Colorado. Now rare or extinct in all settled parts east of the Rocky Mountains.

In Missouri formerly a permanent resident nesting on the cliffs along the rivers. Audubon mentions seeing several Ravens, May 7,1843 , near the northeast corner of the state. Prince of Wied met with them near the same place, May 1, 1833. Dr. Hoy has the Raven in his list, made in 1854 in western Missouri, and Dr. J. A. Allen found it "apparently common" in 1872. 
From the cliffs in the vicinity of New Haven they disappeared in 1881 according to Dr. A. F. Eimbeck. The last record of their breeding in Missouri comes from Hahatonka, Camden Co., where Mr. Philo W. Smith, Jr. secured five eggs, slightly incubated, April 5, 1901. He writes: "The nest was about one mile from Hahatonka on a shelf of rock, a mere platform of sticks, with strips of bark, corn husks, a little hair, etc. There were as near as I could judge about six pairs of birds. I think this is the same colony of Ravens that nested a few years before near Vienna on the Gasconade and which I made two unsuccessful trips to locate."

[486a. Corvus corax principalis Ridgw. Northern Raven.]

Corvus corax. Corvus corax var. carnivorus. Corvus carnivorus. American Raven.

Geog. Dist.-Aretic and Boreal provinces of North America; south to western and northern Washington, Great Lakes, New England and higher Alleghanies. According to Mr. R. Ridgway the status of the Ravens breeding east of the Great Plains and south of the Great Lakes has, for lack of material, not been fully determined. It is possible that they form the connecting link and may therefore be placed in either of the two subspecies.

Mr. M. P. Lientz of Fayette, Howard Co., reported to the Department of Agriculture in the early eighties that the Raven was once numerous but then rare. Mr. Wr. E. Pracger wites, that there is a specimen in the collection of Mr. Heiser, druggist at Keokuk, which was shot many years ago near Hamilton, Ills., opposite Keokuk. On October 23, 1892, Mr. F. M. Woodrufi of the Chicago Academy of Science took a typical example of this subspecies at Meredosia, Ill., less than fifty miles from our state line.

*488. Corvus brachyrhinchos C. L. Brehm. American Crow.

Corvus americanus. Corvus corone. Corvus frugivorus. Crow.

Geog. Dist.-North America to southern border of United States (except Florida in summer); north to Newfoundland and Magdalen Islands, Nelson River and lower Anderson River.

In Missouri a common resident on all cultivated land, but shunning deep forests and therefore rare in the Ozarks and the southeast. Constant warfare with gun and poison has greatly 
thinned its ranks during the last twenty years. We still call it a common summer resident, only because its size, color and mode of living in the open make it possible that not a single individual escapes notice. A like number of a small, plain colored, secretive species would constitute one of our rarest breeders. Lately their killing for millinery purposes has been openly recommended by newspapers as a source of revenue, and whenever the pleasure of killing can be made remunerative devotees are not lacking. As a winter resident the Crow is still numerous, but not nearly as much as formerly. There are many winter roosts, large and small, scattered over the state. Formerly when St. Louis dumped all its refuse and garbage into the Mississippi, the roost on Arsenal Island opposite the southern part of the eity was one of the most frequented in the whole country. Hundreds of thousands assembled there in some winters, chiefly in November and December, until the closing of the river drove most of them farther south below the mouth of the Ohio where the Mississippi never eloses. As long as the river was open the Crows were not in want of provisions even when the ground was buried under snow, and it was a spectacle never to be forgotten to see hundreds of crows dotting the icy shore or drifting down on huge cakes of ice, all eagerly looking out for floating morsels which they picked up cleverly and carried to the shore. Those that had drifted down far enough came flying back low above the water, to take another floating position higher up. All together they made a most animated picture. When little or no snow was on the ground, a state of affairs which may be called the rule in our region, Crows had no difficuty in finding enough to eat, but they had to go many miles for it and visit fields and woods and pastures and sundry places in search of mice and carrion, waste grain and insects, dead or alive, and seeds of all kinds, acorns and whatever is seattered about. Crows are omnivorus and most beneficial seavengers in their winter haunts. They began to come to the island roost early in September, and real migration set in early in October with steadily increasing numbers until the middle of November, when about the maximum frequency was reached and maintained until either ice and snow shut off their food supply or mild and open weather awakened the desire to return to their summer home. All through fall and in moderately cold weather in winter, the Crows spent the nights perched ten to fifteen feet above the ground in the willow thicket of the island, but when the cold became intense they deserted the willows entirely and spent the 
nights on the snow-covered sand bank in front of the willow thicket and exposed to the fierce northwest and north wind. When they had gone in the early morning, every bird had left the imprint of its body in the form of a light depression in the snow with a hole in front made by the bill and a few heaps of excreta on the opposite side, showing the bird had spent all night in that position, always with the head turned toward the wind, letting the wind sweep over its back, but keeping the feet from freezing. The exodus from the roost in the early morning and the influx in the afternoon was always a source of great delight to the lover of animated Nature as it is one of the most imposing sights imaginable. The Crow with all its real and alleged faults would be sadly missed by all who have the gift of looking above dollars and eents in the search of happiness and find it in the admiration of animated Nature, nota small part of which we owe to this graceful, interesting ornament of any and every sort of landscape.

\section{Nucifraga columbiana (Wils.). Clarke's Nutcracker. \\ Corvus columbianus. Picicorvus columbianus. Clarke's Crow.}

Geog. Dist.-Coniferous forests of western North America from New Mexico, Arizona and northern Lower California to northwestern Alaska. Accidental in South Dakota, Nebraska, Kansas, Missouri and Arkansas.

In vol. 12 of the Auk Mr. John A. Bryant of Kansas City, Mo., reports the capture of a fine adult bird killed about October 28, 1894, four miles east of Kansas City. The Arkansas record is from Earl, Crittendon Co., less than twenty miles from the Mississippi River and eighty miles south of our state line; the bird was taken April 1, 1891. The Kansas record is from Marshall Co., in the northeastern part of the state, August 13, 1888. There is also a record from Omaha, Neb., and another from Alda in southeastern South Dakota, October, 1883, but all should be considered purely accidental visitants.

Family Icteridae. Blackbirds, Orioles, etc.

*494. Dolichonyx oryzivorus (Linn.). Bobolink.

F'ringilla oryzivora. Emberiza oryzivora. Reedbird. Ricebird.

Geog. Dist.-Eastern North America; west to Utah, northeastern Nevada, Idaho and southeastern British Columbia; north 
to $40^{\circ}$ lat. on the Atlantic coast and to $52^{\circ}$ lat. in the interior. Breeds from Pennsylvania, northwestern West Virginia, central Ohio, central Indiana, northern Illinois, northern Missouri, Nebraska and Utah northward. Migrates through West Indies, Yukatan, Central America to South America as far as Paraguay, southern Brazil, Bolivia, ete., also Galapagos and Bernudas.

In Missouri the Bobolink is a fairly common transient visitant throughout the state, except the heavily wooded parts, though not an entire stranger even in the narrow valleys of the Ozarks. In fact the numbers which pass through Missouri are much larger than it would appear to those not initiated, because they are not scattered broadcast over the territory, but migrate in small flocks and visit only certain favorite meadows in which they are easily overlooked when feeding silently on the ground. The forerumners, usually males, appearing in the last week of April, are sometimes kept back by adverse weather several days, but the bulk of the species passes through when the weather is not as changeable as earlier in the season, thus permitting a rapid advance without long stop-overs. The largest flocks are met with the second and third weeks of May; at first mostly males are seen, then mixed flocks, and at last flocks in which the females predominate. In some years all are gone soon after the middle of May, in others not before the last of the month. The noticing of their passage in autumn is still more a matter of initiation than that of their spring migration. In spring there are always moments when the whole or part of the flock fly up from their breeding grounds, alight in a tree and give expression to their feelings by an outburst of music; or musically inclined individuals pass by, going north, singing as they go. In autumm music is heard only very exceptionally and just as rarely do we see a male partly clothed in its summer dress; the fashion at this time is the conventional traveling dress, in which it easily passes for something else. It is the peculiar "pink, pink" that betrays its presence when, high in air, it is passing south, or changing from its feeding grounds in the fields beyond the blufis to the common roost in the grasses of the marsh, where it spends the nights in company with different kinds of Swallows and marsh loving members of the Blackbird family. August 20 is about the time when the marshes of northern Missouri see the Bobolinks flock in at night to roost, and it takes the species a whole month to leave that part of the country, the last date for St. Charles Co. being September 24. 
Records of its breeding are few and we must for the present consider the speeies a rare summer resident in northern Missouri only. Mr. Currier knows of its nesting in Clark Co. in 1897, and Mr. Parker says it breeds in Montgomery Co. Professor I. W. Kilpatrick reported the Bobolink as a rare summer resident in 1885 at Fayette, Howard Co. In Mr. Lynds Jones' list of birds seen June 29, 1900, on his way through northern Missouri from La Plata, Macon Co., to Kansas City, i. e., south of $40^{\circ}$ lat., the Bobolink has found a place. Trippe in his list of birds of Decatur Co., Iowa, just across the state line, says of it: "Breeds locally."

*495. Molothrus ater (Bodd.). Cowbird.

Emberiza pecoris. Icterus pecoris. Molothrus pecoris. Fringilla ambigua (juv.)

Geog. Dist.--North America, except portions of Pacific eoast; north to about lat. $49^{\circ}$ in the East, and to $55^{\circ}$ in the interior; west to British Columbia, Washington, Oregon, Nevada and southeastern California. Breeds from Georgia, Louisiana and Texas (San Antonio and Houston) northward and winters from the Southern States southward to Yucatan.

In Missouri a common summer resident on all cultivated land throughout the state, even in the valleys of the Ozarks, but avoiding deep woods and therefore rather rare in some of the southern counties and in the southeast. A few winter in the state, not only from St. Louis southward, but in mild winters also in the northern part, as reported by Mrs. Musick from Mt. Carmel, Audrain Co., December 25-28, 1884, and January 21 and 24, 1886, and by Mr.M. P. Lientz from Linwood, January 30,1889 and January \&, 1890. The very first Cowbirds come in the company of Redwings about the first of March, but are easily overlooked as they do not appear in their old haunts, staying with the host of Redwings in the marshes. As is the ease with all other March arrivals, the dates of first Cowbirds vary greatly with the weather from the second week of March to the first week of April. The bulk of the species generally does not come before the first or second week of April and in the nore northern part before the second or third week. It is usually not far from April 1 when the first male Cowbird announces from a treetop that he is back again at his old stand and ready for mischief, but it is a week or more before he gets a chance to court. After the 
females have arrived in force by the middle of April the species becomes for nearly two months one of the most conspicuous, especially in the morning hours, when its call note is in the air everywhere, its song is coming from the treetops, and restless troops of exeited males and females follow or chase each other, the males usually in the majority. The Cowbird is one of the most social birds and even during the period of mating and oviposition troops of from 20 to 30 are seen in the evening going to the common roost in the river bottom. These troops are joined by the young ones as soon as they can dispense with the care of their foster-parents. Together they visit pastures and stubble fields, roaming more and more as the season advances, until, in September, migration begins and many of their summer haunts are deserted. The willow thickets covering the shores and islands of the Mississippi and Missouri Rivers offer safe retreats to migrants of all kinds and thither large flocks of wandering Cowbirds repair in the evening to spend the night in company with Grackles, Martins and others. In October they join the different kinds of blackbirds in the marshes, where the thickly tangled weeds and grasses offer warmer quarters than the willows along the rivers. Not many Cowbirds are with us after the first of November, but as in early spring, a few stay with the Redwings until real winter drives them farther south. Much has been written about the damage done by the Cowbird's parasitie habit, but no hypothesis has ever been offered as to the origin of this peculiar habit. Ten years ago the author published the following eonjecture in "Science," new series, vol. 5, no. 109, on the "Origin of Parasitism in the Cowbird." "Reproductive parasitism, as we find it in the Cowbird, is such a rare exception to the rule among higher animals, where parental affection is highly developed, that it never ceases to be an object of speculation as to its origin. There are two peculiarities for which our Cowbird is renowned: the one which gives him his scientific name Molothrus, a parasite; the other which causes him to be called Cowbird, his strong attachment to grazing animals especially horses and cattle. Now, should there not be a connection between these two traits? Nobody would think that the habit of following horses and eattle has been formed since the introduction of these animals by the white man. Its Indian name Buffalo-bird was certainly no misnomer and it can hardly be questioned that for ages the buffalo, or Ameriean bison, was the animal which, in the economy of our Cowbird, 
played the part now taken by the domestic animals. The distribution of the one coincides in the main with that of the other, except that in recent years the Cowbird has extended its range to follow domesticated eattle. A few years ago the bison roamed over the greater part of eastern North America from the Atlantic to the Rocky Mountains, in suitable places, and it was not until the last century that it became exterminated in the territory east of the Mississippi River. But the habits of the Cowbird were probably formed before the bison and the Red Man were on the scene, since some speeies in southem South America have similar traits. The Cowbird, like all other leteridae, have their origin in South America, and of the twelve species and subspeeies known, only three enter the United States. Not all the species are parasitic: of some we do not know the mode of reproduction, but Molothrus badius of Argentine, Paraguay and Bolivia builds its nest and rears its young like other birds, and there was undoubtedly a time when Molothrus ater did the same.

"We know that fossil remains of hor'ses, not much unlike ours, are found abundantly in the deposits of the most recent geological age in many parts of America from Alaska to Patagonia. It was probably at that period that the Cowbird aequired the habit of accompanying the grazing herds, which were wandering continually in seareh of good pasture, water and shelter, in their seasonal migrations and movements to escape their enemies. As the pastoral habit of the bird became stronger, it gave rise to the parasitic habit, simply because, in following the roving animals, the bird often strayed from home too far to reach its nest in time for the deposition of the egg, and, being hard, pressed had to look about for another bird's nest where-in to lay the egg.

"After the aequisition of the roving habit it is not difficult to imagine that such eases occurred quite often, especially when with the change of climate both, birds and mammals, spread more and more into the temperate regions, where the spring movements of the grazing animals fell together with the bird's breeding time. By a combination of favorable circumstances this new way of reproduction proved successful, and the parasitic offspring became more and more numerous. In the course of time the art of building nests was lost, the desire to incubate entirely gone, paternal and conjugal affeetion deadened, and parasitism had become a fixed habit." 
*497. Xanthocephalus xanthocephalus (Bonap.). Yellowheaded Blackbird.

Icterus xanthocephalus. Agelaius xanthocephalus. Icterus icterocephalus. Xanthocephalus icterocephalus.

Geog. Dist.-Western North America, east to western Missouri, northeastern Illinois, southern Wisconsin, northwestern Indiana, northern Minnesota, Manitoba and Keewatin; north to Athabasca and southern British Columbia. Breeds from northern Mexico northward locally throughout its range and winters from Louisiana and Texas southward through most of Mexico. Accidental stragglers in Eastern United States, Cuba and Greenland.

In Missouri the Yellow-headed Blackbird has been found breeding west of a line drawn from the northeast to the southwest corner of the state. Mr. Ed. S. Currier took three sets of eggs in Clark Co., May 28, 1895. I found several pairs, June 19, 1906, at Renick's Lake, Saline Co.; W. E. D. Scott gives the species as breeding in Johnson Co. in 1874 and Mr. H. Nehrling found it breeding in the cighties at Sarcoxie in Jasper Co. Its breeding range was formerly more extended eastward, as Dr. A. F. Eimbeck knows of its breeding in the vicinity of New Haven, where he says it arrived in Narch and remained until November (November 3, 1903; November 6, 1902.) As a transient visitant it is well known in western Missouri and seems to have been quite common formerly. Prince of Wied mentions it on three days between Leavenworth and the northwest corner of Missouri, April 22 and 27,1833 , when he speaks of flocks of it, and again on his return, May 18, 1834. Audubon and Harris met it near the northwest corner, May 9, 1843, and Dr. E. Coues found it at Fort Leavenworth. Mr. Prier gives it as a fairly common transient visitant at Appleton City, St. Claire Co., in 1906, and there are several migration reports from Jasper, Vernon and Jackson Counties with dates varying from the last of March to the tenth of May. From St. Louis southward it must be regarded as a rare straggler, but was observed at Old Orchard. In St. Cliarles Co. it has repeatedly been found singly or a few together with troops of Redwings. It is also reported from Audrain Co., May 15, 1885, by Mrs. Musick, and has occurred at Warsaw and Keokuk as an irregular visitor. 
*498. Agelaius phoeniceus (Limn.). Red-winged Blackbird. Agelaeus phoeniceus. Icterus phoeniceus. Sturnus predatorius. Swamp Blackbird.

Geog. Dist.---Eastern United States and more southern British Provinces, except Gulf coast and Florida; west to eastem base of Rocky Mountains. Breeds throughout its range and winters from southeastem Nebraska, central Illinois, Indiana, southerm New Jersey, southward.

In Missouri a common summer resident in all open districts, on wet meadows in the valleys of the Ozarks, on the open swamps of the southeast, in the marshes of the floodplains as well as throughout the prairie region north and west, but always near water. The floodplain of the Mississippi is certainly the great thoroughfare for countless millions of different kinds of blackbirds, by far the most numerous of which is the Redwing. The thickly matted marsh grasses offer excellent shelter at night and the corn shocks on adjacent farms keep them from starving when nothing better can be had. As far north as St. Charles Co. Redwings are loath to leave in winter and small troops either of this species or of the lately separated northern subspecies may be seen in the coldest months. Unusual rigor may drive them farther south for a few weeks, but they are back again with the first warm spell. Soon after the middle of February migration begins in earnest, the vanguard spreading over southern and central, sometimes even over northern, Missouri before the first of March. After this first advance there is often a lull until the middle of March when the great host reaches the state in immense flocks of northbound transients. At the same time the first old males take up their favorite perches and announce that they intend to oceupy them again the coming season. With the wonted vicissitudes of the season migration drags through April and nearly to the middle of May, troops of females forming the rear guard after the main army has departed and probably reached the northern home. In the meantime the ranks of our summer residents have filled up, the females have at last joined their long-suffering mates, courting is going on with much show and ado until toward the end of May domestic considerations bid them be reserved and cautious. When the young are grown they join the parents in roving over the country in search of favorite dishes and secure roosting places, flying daily many miles to the willow thickets in the river bottoms or the Spartina stretches in the marshes. 
Early in October migration from the north begins to get brisk, reaching its maximum about the middle of the month, when on some days enormous masses congregate in the marshes, pouring in from different directions in perfect streams for an hour before sunset. An equally grand spectacle greets the beholder in the early morning, when they leave the marsh in compact columns diverging in different directions. While after the first of November the main body of the invading army has departed, enough are left to the end of the month to fill with marvel and surprise the tyro in the marsh.

498d. Agelaius phoeniceus fortis Ridgw. Thick-billed Redwing.

Northern Red-wing.

Geog. Dist.--Breeding range: Athabasca, Mackenzie and other interior districts of British America. During migration the Great Plains from eastern base of Rocky Mountains to Manitoba, Minnesota, Nebraska, Indian Territory, western Illinois, Kentucky and southward to Arizona and western Texas.

According to the geographic range a part of the incalculable numbers of Redwings which pass through Missouri in spring and fall must belong to this subspecies, which is decidedly larger with a shorter and thicker bill. Specimens were taken at Burlington, Ia., October 12 and 13, 1895; Monana Co., Ia., October 14, 1884; Blue Lake, Ia., October 22, 1884; in Henderson Co., Ill., March 12, 1893, and in Kentucky, December 15, 1894.

\section{*501. Sturnella magna (Linn.). Meadowlark. \\ Alauda magna. Sturnus ludovicianus. Sturnella ludoviciana.}

Geog. Dist.-Eastern North America, north to Ontario, rarely to Quebec and the Maritime Provinces, and Minnesota: west to western Iowa, eastern Kansas, Indian Territory. Winters occasionally in the northern states, but generally from Kentucky and Virginia southward to the Gulf.

In Missouri a common summer resident in all open districts, therefore most plentiful in the prairie and Ozark border regions, scarce in the Ozarks and the southeast, and apparently entirely replaced by the Western Meadowlark in the northwest corner of the state. Some remain with us in winter and many more would probably do so if permitted, but Meadowlarks are considered game birds and few succeed in living through winter. 
The new game law of 1905 protects the species, and it is our hope that this will have a beneficial effect, as the number of summer residents and transients has been greatly reduced. The first Meadowlarks return to Missouri with great regularity during the first week of March, exceptionally in February or in the second week of March; the bulk comes between the 10th and the 18th, exceptionally later, as March 31, 1906. Troops of transients are with us until the last week in April and again from the last week of September to the last week of October. After quail shooting begins November 1, Meadowlarks get scarce, and by the end of the month only winter numbers, i. e., very few, are left.

*501b. Sturnella magna neglecta (Aud.). Western Meadowlark.

Sturnella neglecta. Sturnella ludoviciana.

Geog. Dist.-Western United States, southwestern British Provinces and northwestern Mexico; east to Manitoba, Minnesota, Wisconsin, Iowa, northern Missouri, Indian Territory and Texas.

The prairie region of Missouri is undoubtedly one of the best fields for the study of the relationship of the two forms of Sturnella, magna and magna neglecta. The true Eastern Meadowlark occurs throughout southern Missouri to the exclusion of the true Westem except in migration, when typical neglecta are regular transient visitants along our western border. Typical Eastern Meadowlarks oceur as summer residents throughout northern Missouri except the northwest comer, where, in the region of Langdon, Atchison Co., only tpyical Western were observed in June 1906. Together with the true Eastern, true Western breed in Nodaway Co., the next county east of Atchison Co. Mr. B. M. Stigall of Kansas City, who became acquainted with the Western in Colorado, writes that during June and July 1906, which he spent at Maryville, Nodaway Co., Mo., he heard both, magna and neglecta, singing in the same field. How far eastward the true Western is found breeding has not been determined, but, together with the true Eastern Meadowlark, forms occur which cannot properly be placed with either one of the subspecies because intermediate. They are found as far east as the counties bordering the Mississippi and as far south as Montgomery and St. Charles counties. The typical Western rarely straggles as far east as St. Louis Co. where it was only 
once met with at Old Orchard, in the spring 1896, remaining a few days singing gloriously.

The question whether the two forms, St. magna and neglecta, are true species or subspecies still awaits solution, requiring extensive field work, but offering an excellent opportunity for profitable study. Mr. J. A. Allen was the first to observe in 1867 "that the Meadowlarks of northern Illinois differed in song quite markedly from their relations in the eastern United States, the departure being in the direction of that of var. neglecta." (See Mem. Bost. Soc. Nat. Hist. vol. 1, pt. 4, 1868, pp. 496, 497). Dr. Elliott Coutes in his Birds of the North-west, 1877, writes: "At the edge of the western prairies St. magna begins to shade into var. neglecta, which reaches its maximum departure on the dry central plains." and again: "The case of Sturnella magna neglecta is settled and explained; magna shades directly into neglecta. The change is imperceptibly effected." In vol. 5 of the Nuttall Bull., 1880, Mr. W. J. MeGee of Farley, Ia., writes: "I saw several individuals (notably one near Rudd, Floyd Co.), which I was totally unable to satisfactorily identify with either S. magna or S. neglecta, either by markings, habits, attitude or voice. They seemed to hold an intermediate position, in all characters, between the best marked extremes." The well-known author of "The Story of the Birds," Mr. James Newton Baskett, of Mexico, Mo., who was the first to call the attention of ornithologists to the hybrid song of Meadowlarks in northern Missouri (Auk, vol. 13, p. 258, 1896) writes me: "There can be no doubt about the inter-grading of the two kinds. I have had several correspondents to confirm this-especially from Iowa and Minnesota."

In his "Study of the Genus Sturnella," Bull. Am. Mus. Nat. Hist. vol. 13, 1900, Mr. Frank M. Chapman makes the following instructive remarks in regard to the seasonal change in color and pattern: "The fact that Meadowlarks have only a post-nuptial molt and that when the breeding season arrives, wear and fading have deprived their plumage of its most characteristic colors and markings, greatly complicates the study of their relationships. The fall molt is concluded in September and from that month until January there is not sufficient change in plumage to interfere with the proper identification of specimens. After January, however, fading and wear often so alter a bird's appearance that its identity cannot be determined with certainty. It follows, therefore, that the different characters of these birds 
are best exhibited in the fall and are least apparent in the breeding season, an unfortunate condition of affairs as every systematist will readily recognize." Of a specimen in the collection of the Biology Survey, a male taken July 13 at Golden City, Mo., he writes: "S. magna apparently approaching neglecta, but in too worn plumage to be satisfactorily determined." And of a young bircl taken at the same place on the same day: "Apparently intermediate, the central tail-feathers abnormally marked with white." What Mr. Chapman says of the song is highly interesting: "Some advocates of the specific distinctness of the eastern and western Meadowlarks have attached much importance to the marked and well-known differences in the songs of these birds, and while these differences are doubtless of value in making field identifications, they should not, I think, be given importance by the systematist. Song is largely if not wholly an uninherited character and is subject to great individual and geographical variation. In both magna and neglecta this statement is usually well illustrated by the wide range of variation occurring in their respective songs. Dozens of strikingly different songs of neglecta have been recorded, its vocal powers have been described as being a 'husky whistle' and as excelling those of the Nightingale; and while this difference is no doubt partially in the ear of the hearer, it nevertheless attests a wide range of variability. Similar differences are to be observed in the eastern Meadowlarks." Speaking of a series of specimens from southern Texas, Mr. Chapman says: "There can be no doubt that they prove the complete intergradation of magna and neglecta. Whether this intergradation is geographical, that is, correlated with elimatic conditions, or whether it is due to the interbreeding of typical examples of magna with typical examples of neglecta, can only be determined by farther field work."

Mr. Chapman's paper concludes with the following very acceptable theory: "Assuming that Meadowlarks originated in the humid tropics, we have, as the ancestral form, a clark bird, which, spreading northward along the coast and over the Mexican tablelands, retained its dark colors in humid regions and acquired a paler color in arid regions. If the assumption of the origin of both birds from a common ancestor be accepted and if their geographical intergradation at the southern limits of the range of neglecta be established, we are then in a position to explain their apparent association as species in the more northern 
part of their range, on the ground that while their ranges originally diverged like forks of a $\mathrm{Y}$, the ends have finally come together, not as geographical intergrades, but as two forms, both of which have occupied the region where they are found associated at so recent a date that neither shows the effect of the climatic conditions under which it lives, but exhibits the characters carlier acquired.

"In the Mississippi Valley, therefore, we have the apparent anomoly of two geographical races or subspecies of the same species breeding at the same place, and, occasionally associated with them, are certain intermediate specimens showing in varying degrees the characters of both extremes. Since it is out of question to suppose that the same environment could produce three phases of the same species at the same place, that is, neglecta, magna, and intermediates between the two, we can only suppose that such comecting specimens are not geographical intergrades but the results of a union between neglecta and magna. In fact, loosely speaking, these connecting specimens would be termed hybrids, but, accepting as a definition of this word "the offspring of animals of different species," it is evident that in a strict sense it cannot be applied to these intermediates, which are in the progeny of parents not specifically distinct."

[501c. Sturnella magna argatula Bangs. Southern Meadowlark.]

Geog. Dist.- Southern United States from Florida to Louisiana, north to southeastern Illinois and southwestern Indiana within the limits of the Austroriparian or Lower Austral lifezone.

This smaller and darker subspecies should be looked for in our southeastern counties.

*506. Icterus spurius (Linn.). Orchard Oriole.

Oriolus spurius. Oriolus mutatus Wils.

Geog. Dist.--Eastern United States, breeding from southern Texas and northern Florida north to Connecticut, southern New York, southern Ontario, southern Michigan, southern Wisconsin, central Minnesota and South Dakota; west to $100^{\circ}$ meridian. In winter to Mexico, Central America and northern Colombia, Cuba.

In Missouri one of our most common and generally distributed 
summer residents, originally inhabiting the timber along water courses, but now taking to orchards, gardens and even the shade trees around houses and the streets of towns and cities. It is one of the commonest species in the Ozarks, wherever there is a settlement, on the ridges as well as in the valleys. The first come to southern Missouri soon after the middle of April, to central Missouri in the fourth week, and to the more northern part of the state the last days of the month or the first few days of May, when the bulk of the species has generally spread all over the rest of the state. The first to arrive are the old males followed after a few days by the first females and the first males of the second year. It is from one to two weeks after the first males have come before their full strength is reached and their song heard everywhere. After the young are grown the species roams in July and August in troops through the country living mostly on wild eherries, wild grapes and other wild fruit, sometimes visiting orehards. After August 20 the species is seen only occasionally, though we may eome upon a few later in the month or in early September, exceptionally later (September 17, 1903, New Haven; September 21, 1903, Kansas City).

*507. ICterus galbula (Linn.) Baltimore Oriole.

Oriolus baltimore. Icterus baltimore. Yphantes baltimore. Hangnest.

Geog. Dist.-Eastern North America, breeding from southern United States, exeept along Gulf coast, north to Maritime Provinees, Quebee, Ontario and Manitoba; west to eastern Assiniboia, Montana, Wyoming and Colorado east of the Rocky Mountains. Winters through eastern Mexico and Central America to Colombia and Venezuela.

In Missouri a common summer resident except in the Ozarks where it is found in the larger valleys only. Originally the Baltimore inhabited the trees overhanging streams and it still follows this fashion in the southeast, where its loud wild notes fit well to the weird seenery of those desolate waters. With the settlement of the prairie region it was not slow to see the advantages of a eloser contact with modern conditions and now hangs its nest in the shade trees next to human habitation, but fortunately so far out of reach of enemies that the species ean not only hold its own, but is enabled to spread to seetions not inhabited before. The first male Baltimore arrives in southeast Missouri at the end of the first or beginning of the second week 
of April; at St. Louis sometimes at the end of the third, more commonly at the beginning of the fourth weck and in the northern part of the state during the fourth week or the last days of the month. The females and first young males of the second year come a few days later and full numbers are not present before the first week of May. Transient visitants swell their numbers during the first half of May and are sometimes met with in small troops in unusual places in the woods and in regions where they are not breeders, as on the dry hills of the Ozarks.. When the young, which soon outgrow their nest and, sitting around in trees, play for a while a conspicuous part by their loud clamoring, are fully grown, the family leaves the breeding haunts and roams in search of favorite diet, chiefly caterpillars and fruit. At this period it is seldom heard, the species displaying a tendency to secrecy, which accounts for its temporary rarity in late July and early August. But before its departure after migration from the north has set in, the Baltimore becomes for a few days prominent again, calls loudly and visits its old haunts, as if to bid good-bye. Ours may be said to be gone by September first, but stragglers are encountered frequently until the middle of the month, even in the northern part of Missouri.

\section{Euphagus carolinus (Müll.). Rusty Blackbird.}

Scolecophagus carolinus. Scolecophagus ferrugineus. Gracula ferruginea. Quiscalus ferrugineus. Turdus carolinus. Rusty Grackle. Thrush Blackbird.

Geog. Dist.---Eastern and Northern North America; breeding from Nova Scotia, New Brunswick, northern Maine, White Mountains, Vermont and northern New York, northern Michigan, north to Ungava and northwestwardly to the Arctic coast and Alaskan shores of Bering Sea. South in winter to Southern United States; west in migration to central Nebraska, Kansas and Texas, wintering from Lower Missouri and Ohio Valleys southward.

In all parts of Missouri a common transient visitant and in the more southern part not a very rare winter resident, frequenting barn yards when other food supplies are cut off. Migration begins in latter part of February, but no great progress is made until about the second or third week of March, when the species becomes for a week or two common in most parts of the state. In some years the bulk of the species has passed northward at 
the end of the first week of April, but, as is the ease with other early migrants, cold weather may retard progress for weeks and the first half of April be the time for the chief passage of Rusty Blackbirds through Missouri. The "lasts" have been recorded all the way from the first of April (1905, Shannon Co.) to April 23 (1874, Johnson Co.). The earliest date in fall migration is September 28, 1896, at the northeastern corner of the state (Currier), but usually the first do not reach Missouri before the second week of October. They mingle and roost with the Robins or with the Redwings in the reeds of the bottomlands. After this there is a steady decline until toward the end of November winter numbers only are left.

510. Eupragus cranocephalus (Wagl.). Brewer's Blackbird. Scolccophagus cyanocephalus. Quiscalus breweri. Blue-headed Grackle.

Geog. Dist.-Westem North America; breeding from southern Texas and Mexico north to British Columbia, Alberta, Saskatehewan and Manitoba; east to Minnesota, Nebraska, western Kansas. During migrations straggling east to Wisconsin, Iowa, Illniois, South Carolina and Louisiana. In winter over the whole of Mexico into Guatemala.

Has been reported from Freistatt, Lawrence Co., by Mr. H. Nehrling, who met with a party of five, March 1, 1885, and a troop of twenty, November 7, 1886. It is probably more common than we know and should be looked for along our western border, since Professor Snow states that it is "quite common even in eastern Kansas." Dr. Allen says that "from its size, eolor and habits it may readily be mistaken for the Purple Grackle of the East." The male is lustrous greenish-black, changing abruptly to purplish and violet on the head. The female and young are distinguished from those of $E$. carolinus with some difficulty, but they average larger, with the bill heavier at the base, and are probably never so decidedly rusty-brown (Coues, Birds of the North-west).

*511b. Quiscalus quiscula aeneus (Ridgw.). Bronzed Grackle.

Quiscalus versicolor. Quiscalus purpureus. Quiscalus aeneus. Quiscalus purpureus aeneus. Grackle. Crow Blackbird. Common Blackbird.

Geog. Dist.-Eastern North America except Atlantic coast district from shores of Long Island Sound southward and the Gulf coast from Florida to Louisiana; northward through Mari- 
time Provinces to southern Newfoundland, southern Labrador, Great Slave Lake and Prince Albert; west to base of Rocky Mountains in Montana, Wyoming, Colorado and New Mexico. Winters chiefly in the Lower Mississippi Valley south of lat. $35^{\circ}$, occasionally farther north.

In Missouri the Bronzed Grackle is one of the common and generally distributed summer residents on open land, nesting in small colonies, preferably near human habitation. In southeastern Missouri they still nest in tree holes in deadenings; elsewhere they choose evergreens and other heavily foliaged shade trees for nesting sites. In the Ozarks, which were formerly densely wooded, the species is still rare as a breeder, even in places which have long been cleared and cultivated. As a winter visitant the Bronzed Grackle is rare except along the Mississippi River from St. Louis southward. Opposite St. Charles along the bank of the Missouri River there is a large swampy tract of willows used as a winter roost for innumerable Redwings, and with them hundreds of Bronzed Grackles have been seen going even in the middle of January, in mild weather, but as their numbers change constantly, there are hardly two days alike, showing that they also use other roosts farther south, to which they fly when the weather is not inviting northward. Should weather conditions remain unfavorable the roost may remain deserted or nearly so for weeks at a time, until a change sets in when they appear again. Away from the roost they are seldom met with, because they go far to favorite feeding grounds and scatter over a large territory. Real migration begins in the latter part of February and in early March in the southeast; it reaches the central, and along the Mississippi River even the northern, counties in the second, less often in the third week of the month, very rarely later, as in 1906, when winter reigned to the end of March. The first-comers are probably mostly transients, bound for the far north, keep in dense flocks and roost in the river bottoms. It is only after the bulk of the species has invaded the state during the latter half of March, that the first of our summer residents make their appearance on the breeding grounds and announce that they intend to occupy them again as soon as their mates have arrived. They return in the evening to the common roost and, should the weather turn bad, are not seen at their old stands again for days, but as soon as warm weather sets in they return, are joined by the first females, and mating begins with much chasing and noise making. The 
transit of tremendous flocks of migrants continues through the first two weeks of April, during which time the ranks of summer residents fill up, and nest-building begins. During all this time of mating and nest-building, and until incubation begins, the whole colony leave the breeding ground in the cvening and go to the common roost, preferably willows in the bottoms, to which they come from all sides for miles to spend the night together. As soon as the young are able to fly so far, about the first of July, they also follow the parents to the common roost. While not very popular with some agriculturists, they are well liked by others, who appreciate their services when following the plow or doing other useful jobs in eleaning the fields of vermin. With their glossy plumage, elegant shape and graceful walk they are quite an ornament in parks and on the lawns of the suburbanites and, though not protected by law, and subjected to much persecution, they still hold their own, thanks to a great deal of foresight which permits them to increase their numbers two or three fold before the end of July. They are very cautious in locating their nests, which are not easily deteeted though bulky. As incubation advances they become very quiet and when feeding young are little seen in the immediate vicinity of the nest, but approach it stealthily and bring the food from great distances. The young grow very fast and the nest becomes too small a week or more before they are able to fly, but having strong legs they erawl out and perch on branches of the surrounding trees. At this time the whole family becomes a nuisance. The ever hungry youngsters keep up an incessant discordant clamor, and the parents raise their not melorlious voices as soon as someborly approaches one of the trees in which their objects of solicitation are hidden. Only one brood is raised, but if the eggs or newly hatched young should be destroyed, as they sometimes are by severe windstorms blowing (lown the bulky nests, another attempt is made, which accounts for unusually late broods. If all goes well, the Bronzed Grackles of St. Louis Co. leave the breeding grounds entirely early in July not to return until the next spring. Troops of them roam over the country, forming large flocks which retire in the evening to common roosts used by many flocks. Southward migration begins early in October, when large flocks pass over, but the movement does not reach its maximum before the middle of the month, when immense numbers go to roost in the marshes with the Redwings. The numbers vary daily but grow less toward the end of the month 
and during the first half of November, reaching winter conditions before the first of December.

Family Fringillidae. Finches, Sparrows.

514. Hesperiphona vespertina (Coop.). Evening Grosbeak.

Fringilla vespertina. Coccothraustes vespertinus. Coccoborus vespertinus.

Geog. Dist.-Interior districts of North America east of Rocky Mountains; breeding range unknown. In winter from Saskatchewan River south to northern United States and east through Ontario and New York to New England; everywhere irregular and occasionally south as far as Kansas, Kentucky, Pennsylvania and New Jersey.

In Missouri a very rare winter visitant. Mr. J. N. Baskett took a male and female at Mexico, Mo., and saw small flocks on two other occasions. A party of three paid a visit to Dr. A. F. Eimbeck at New Haven, Mo., from September 21 to October 4, 1903. Mr. W. E. Praeger says that a flock was scen and some of them shot, December 14, 1887, in Clark Co., Mo. Two were taken at Belleville, Ill., by Mr. Fuchs and others by Mr. Chas. K. Worthen at Warsaw, Ill., where several were shot out of a flock, five miles below the city on the river bluff. In the Auk, vol. 4, 1887, Mr. L. O. Pindar reports the occurrence at Hickman, Ky., on the Mississippi River between Cairo and New Madrid; one female was found dead March 18, 1887, another was shot March 22, a fine male March 23, and a flock of seven seen in town March 25.

[515. Pinicola enucleator leucura (Müller). Pine Grosbeak.]

Loxia enucleator. Pyrrhula enucleator. Corythus enucleator. Pinicola enucleator. Pinicola canadensis. Pinicola enucleator canadensis. Canadian Pine Grosbeak.

Geog. Dist.--Northeastern North America, breeding from the White Mountains, Maine and New Brunswick north to the limits of coniferous forests; south in winter to New England, New York, New Jersey, Ohio, Indiana, Illinois, Iowa and Nebraska; occasionally farther south to eastern Kansas, western Kentucky, District of Columbia.

As this species is said to be fond of the fruit of the Red Cedar, it should be looked for in the extensive cedar brakes of southern Missouri; its presence may be expected any time between October and April. It has been captured at our state lines 
both in the east and west. In the Auk, vol. 5, 1888, Mr. L. O. Pindar reports the occurrence of a flock of 8 or 10 Pine Groskeaks at Hickman, Ky., February 7, 1888. On the 8th, 11th, and 13th they were again seen, and on the 24 th one male and three females were secured. On the 25th another female was shot and 3 or 4 females were seen March 19th. The Kansas record is taken from Snow, "Birds of Kansas," 3rd ed., 1875, where it is said that according to Dr. Brewer this species was taken once in winter at Leavenworth by Sidney Smith.

517. Carpodacus purpureus (Gmel.). Purple Finch.

Fringilla purpurea. Erythrospiza purpurea.

Geog. Dist.-Eastern North America; breeding from Pennsylvania (in mountains), northern New Jersey, Connecticut, southern Ontario, Minnesota and North Dakota to the Gulf of St. Lawrence, Hudson Bay, Saskatehewan and Alberta. In winter from eastern Nebraska, Indiana and New Jersey southward to Florida and eastern Texas.

In Missouri a common transient visitant and not a rare, but irregular, winter resident, much more common in eastern than in western Missouri. Their presence in winter is not so much dependent on temperature as on abundance of favorite food, which they find chiefly in the river bottoms, as Ash and Syeamore seeds, buds and seeds of Elm and Maple, Ambrosia seeds, etc. Migratory movements begin with the first warm weather in February, when the hardiest sparrows, Bluebirds, Robins, Redwings, Ducks, Geese, etc., advance northward. About March 10 migration becomes brisk and during the rest of the month and until April 20 large flocks of singing birds are present. The last birds, chiefly females and young males, are usually noted during the last week of April, sometimes in the first week of May, or in very backward springs as that of 1907 until May 19 (St. Louis). The first appear in fall migration about September 20 , become common in the first week of October and remain so to the end of the month, roaming about in small flocks and singing often. After the first week of November winter numbers only are left.

521. Loxia Curvirostra minor (Brehm). American Crossbill.

Loxia curvirostra. Loxia americana. Loxia curvirostra americana.

Geog. Dist.-Northern and Eastern North America; breeding in coniferous forests from southern Alleghanies in northern 
Georgia and from Michigan and Wisconsin northward to Nova Scotia and westward through Athabasca and Saskatchewan to western Alaska and southward through Pacific coast districts to western Oregon. In winter irregularly southward as far south as Louisiana, South Carolina, casually to the Bermudas.

In Missouri a sometimes common but irregular transient and winter visitant, appearing in November and disappearing in May, oftenest met with from February 22 to April 1 and about the middle of November. Once seen in summer at Old Orchard. They move in small flocks and are attracted to our parks and gardens by the ornamental pines, chiefly Pinus austriaca, the seeds of which they like very much. They also eat apples left on trees, feed on buds of Elms, seeds of Ambrosia trifida, etc. Their occurrence is reported from all parts of the state. Four males and one female were taken at St. Joseph, December 26, 1894, by Mr. S. S. Wilson. Mr. Chas. Tindall says they are sometimes common at Independence. Dr. A. F. Eimbeck observed them on different occasions at New Haven, October 5 to 16,1903 . Five were shot from a flock of fifteen February 17, 1889, near Keokuk; Mr. Chas. K. Worthen took this and the White-ringed Crossbill at Warsaw, Ill. Mr. E. Seymour Woodruff saw Crossbills in Shannon Co., April 3, 1907, and heard them again April 4. On May 5 he writes: "Small numbers are seen or heard every few days. Last seen May 1st. Their organs show no signs of any possibility of breeding for some time to come."

\section{Loxia leucoptera Gmel. White-winged Crossbill.}

Curvirostra leucoptera.

Geog. Dist.-Coniferous forests of northern North America, south to Prince Edward Island, New Brunswick, Maine, New Hampshire (White Mountains), New York (Adirondacks), Mackinac Island; in winter irregularly as far south as Washington, D. C., Cincinnati, Indianapolis, Bloomington, Ind., southern Illinois, Kansas, Colorado, Nevada, British Columbia etc., also to Greenland and western Europe.

There is little doubt that eareful search will bring to light its presence in Missouri during its extensive wandering in winter. Mr. Chas. K. Worthen took several out of a small flock on the Mississippi bluffs near Warsaw opposite the northeastern corner of Missouri and an adult male was taken November 4, 1899, 
near Lawrence, Kan., within fifty miles of our western state line.

Since the above was written Mr. E. Seymour Woodruff secured a female from among Ameriean Crossbills in Shannon Co. April 1S, 1907.

528. Acanthis linaria (Limn.). Redpoll.

Fringilla linaria. Aegiothus linaria. Linaria minor. Aegiothus puscescens.

Geog. Dist.-More northern portions of northern hemisphere; breeding from the islands in the Gulf of St. Lawrence northward. In winter to northern United States, irregularly to Virginia, northern Alabama, southern Ohio and Indiana, Missouri, Kansas, Colorado, southeastern Oregon and coast of Washington.

In Missouri an irregular, sometimes fairly eommon, winter visitant. Earliest dates, November 4 and 5, 1885, Mt. Carmel; November 18, 1903, New Haven. Latest dates April 1, 1885, April S, 1886, Mt. Carmel and April 12, 1903, Montgomery City. The species is also reported from Kansas City, February 21, to 24, 1882, and repeatedly from Keokuk where it is sometimes abundant. It has on several occasions becn met with in the eity of St. Louis, visiting gardens, feeding on the seeds of compositae, ehiefly in January and February. There are at present no reeords from southern Missouri.

*529. Astragalinus tristis (Linn.). American Goldfinch.

Fringilla tristis. Spinus tristis. Carduelis tristis. Chrysomitris tristis. Carduelis americana. Wild Canary. Thistle-bird. Salad-bird.

Geog. Dist.-Eastern North America, breeding from Virginia, Kentucky and Kansas northward to Newfoundland, Labrador, Quebec, Ontario and Manitoba; west to Alberta, Wyoming and Colorado; south in winter to southern United States, some remaining even in the northern states and Ontario.

In Missouri a fairly common summer resident in open districts, rare in the more densely wooded portions of the state. For nesting it prefers the neighborhood of human habitation from the middle of May to the end of August but likes to rove in troops the remainder of the year. It is also not a rare, but irregular, winter visitant in small troops, associated with other fringillidae such as Tree Sparrows, Purple Finches, Juneos, in migration, also with Yellow-rumped Warblers, Pine Piskins and others. It feeds preferably on seeds of composites, but also on 
Sycamore, Ash, Boxelder, etc., and needing much water is oftener seen drinking than any other sparrow. It is most common and generally distributed as a transient visitant. Those seen before April 20 are mostly individuals which have passed the winter with us and are becoming more conspicuous, assuming slowly their summer dress and beginning to sing. Real migration reaches us with great regularity about April 20 and lasts three weeks to May 10, exceptionally later as in the cold spring of 1907 , May 20. During this time Goldfinches are with us in flocks of from 30 to 60 , mostly in high dress and very musical, assembling in treetops and concerting like Bobolinks or Blackbirds, all beginning or breaking off at the same moment. After the middle of May transients are gone and summer residents are seen in pairs, but it takes them some time to locate and settle down. When the young are grown the family begins to roam and gather into small flocks about the middle of September. Oetober 1 migration from the north reaches us and lasts throughout the month, sometimes in big flocks, frequenting the same localities for resting as in spring. Soon after November 1 winter numbers only are left, wandering in search of food over most of the state, but oftenest found in the flood plains of the Mississippi and Missouri Rivers and in the southeast.

\section{Spinus pinus (Wils.). Pine Siskin.}

Fringilla pinus. Carduelis pinus. Chrysomitris pinus. Linaria pinus.

Geog. Dist.-North America generally, breeding in the northern coniferous forests south to parts of New England, Hudson Valley, on mountains south to North Carolina, to Minnesota, and on the western ranges to the southern boundary of the United States. In winter chiefly in the southern United States, California and into Mexico.

In Missouri a rather irregular transient visitant, sometimes seen in winter, but most records are about the first of November and in the latter part of April. Latest date May 15, 1897, when Mr. Currier saw a flock of ten near Keokuk. They generally move in small flocks by themselves and associate on the feeding grounds with Goldfinches, Purple Finches, Myrtle Warblers, ete. Small troops of them have been reported from St. Joseph by Mr. S. S. Wilson, April 4 and 7, 1896, and from Fayette by Prof. Kilpatrick in January and February 1885. Since the above was written the extraordinary cold spring of 
1907 revolutionized migration dates generally and those of the Siskin in particular. On May 13 the first Siskins were noticed at St. Louis among the large number of Goldfinches present at their old stands which they regularly visit every year and which they frequented this year ten days longer than usual, namely to May 20. From May 16 to 23 inclusive, flocks of from 30 to 50 Siskins were found associated with the Goldfinches at three of those stands, and even after the bulk of the Goldfinches had gone the Siskins remained and their song could then be heard often. They were exceedingly tame, did much of their feeding on the ground and came to the water as frequently as the Goldfinches. In the pine region of Shannon Co. Mr. E. S. Woodruff did not find Siskins before April 28, 29 and 30, 1907, and a flock of from 8 to 12, on May 13 . At Grandin he found small flocks still present on May 16 and 17 and saw one fly by June 4, 1907, ten miles north of Grandin.

Carduelis carduelis (Limn.). Goldfinch.

Fringilla carduelis. Carduelis elegans.

Geog. Dist.-Europe in general except extreme northern portions; south, in winter, to Palestine and Egypt. Introduced into northeastern United States and naturalized in Cuba, in New York City and vicinity, and Cincinmati, Ohio; accidental(?) at New Haven, Conn., near Boston, Worcester, etc., Mass., Toronto, Ont., etc.

Early in the spring of 1870 a few pairs of Goldfinches were introduced into Missouri with other European songsters and liberated in Lafayette Park at St. Louis in April after the weather had become warm. Like most of the other birds liberated at the same time the Goldfinches left the Park almost immediately and the writer never heard of the occurrence of any European Goldfinches in Missouri until the following article appeared in the St. Louis Post-Dispatch: "Liberty, Mo., June 2, 1906. A pair of goldfinches made their appearance in the courthouse yard here and the 'prophets' are unanimous in the opinion that they are the forerunners of an extra hot and dry sunimer. It is the first time in twenty years that this species has been seen here. The birds got their name from a large patch of yellow on their wings. The front of the head and throat are bright red, the nape, with part of the wings and tail, black." 
Passer domesticus (Linn.). House Sparrow.

Fringilla domestica. English House Sparrow.

Geog. Dist.-Europe except Italy. Introduced into United States, where thoroughly and ineradicably naturalized in all settled districts; also Bahamas, Cuba, Nova Scotia, Bermuda and southern Greenland. A resident wherever it occurs.

In Missouri wherever there are houses occupied by human beings.

Passer montanus (Limn.). European Tree Sparrow.

Fringilla montana. Pyrgita montana.

Geog. Dist.-Europe and Asia to China and Japan.

In America only in the neighborhood of St. Louis where it was introduced in 1870 . It has left the thickly settled parts St. Louis but is found scatteringly throughout the outskirts and suburbs, spreading to neighboring cities, Alton, Grafton, and Belleville, III., to Creve Coeur Lake, St. Charles, and westward as far as Washington, 54 miles from St. Louis (September 1906).

\section{Passerina nivalis (Linn.). Snowflake.}

Emberiza nivalis. Plectrophanes nivalis. Plectrophenax nivalis. Snowbird.

Geog. Dist.-Northern parts of northern hemisphere, breeding in aretic and subaretic regions. In America breeding in the barren ground or tundra region from Ungava to Alaska and islands to lat. $82^{\circ}$; in winter south to northern United States, irregularly to District of Columbia, Georgia, southern Ohio, southern Indiana, Kansas, Colorado, eastern Oregon.

In Missouri an apparently rare winter visitant as far south as the Missouri River. First reported from Audrain Co. by Mrs. Musick of Mt. Carmel, December 22, 1884; four days later the species became common; the last were seen, March 24, 1885. Mr. E. S. Currier met with a flock of fifty in one of the roads leading out of Keokuk, Ia., January 17, 1887. Mr. E. M. Parker of Montgomery City found the Snowflakes December 17, 1901, and again in January on 7, 11, 25 and 31, 1902. Mr. Chas. Tindall of Independence saw one on a sandbar in the Missouri River November S, 1892. Mr. Trippe in his Birds of Decatur Co., Ia., just north of central Missouri state line, says in 1872: "A few every winter; abundant in severe seasons." 
536. Calcarius lapponicus (Linn.). Lapland Longspur.

Fringilla lapponica. Emberiza lapponica. Plectrophanes lapponica. Centrophanes lapponicus.

Geog. Dist.-Northern parts of northern hemisphere; breeding in arctic and subaretic regions. In North America chiefly in northeast, including Greenland, Melville peninsula and Cumberland Sound, Ungava etc. In winter south to Virginia, South Carolina, Kentucky, Missouri, Indian Territory and Texas; west to Nebraska, Colorado, Wyoming, where it comes together with the western subspecies, $C$. l. alascensis.

In Missouri a fairly conmon and pretty regular winter visitant, appearing from the north in November and remaining until March. Earliest, November 2, 1885, Mt. Carmel; latest, March 31, 1889, Fayette. They move in flocks of different size, sometimes very large, or in company with Horned Larks, and frequent the wind-swept hillsides of the Ozark border as well as the low marshes of the river bottoms or fields and meadows of the prairie region. Mr. John D. Kastendieck, who took some in Christian Co., considers them rare in his vicinity. Mr. Chas. T. Eimbeck, who has a number of mounted specimens in his collection, finds them common in some winters, rare in others at New Haven, Mo. Mr. Tindall reports a flock of a dozen at Independence, November 10, 1901. Flocks of this species along our western border should be carefully examined, as they may contain McCown's or Chestnut-collared Longspurs and Missouri Skylarks.

537. Calcarius pictus (Swains.). Smith's Longspur.

Emberiza picta. Plectrophanes pictus. Centrophanes pictus. Emberiza smithii.

Geog. Dist.-Interior plains of North America east of Rocky Mountains; breeding in the Mackenzie River valley from the Arctic coast south to the Great Slave Lake and west to the upper Yukon; south in winter as far as Texas; east to northwestern Indiana and Illinois.

In Missouri observed only in the Mississippi bottom of northern Missouri, where probably of regular occurrence, but should be looked for also on higher ground in all parts of the state, as it was taken at Fayetteville in the Ozark region of northern Arkansas, February 28, 1885, and at Lincoln, southeastern Nebraska April 20, 1891. It is given as a common winter resident in Kan- 
sas. Audubon, Harris and Bell found it very abundant on the lowitprairie near a lake a few miles from Edwardsville, Ill., in April 1843. Mr. E. S. Currier regards it as a regular spring migrant and sometimes in fall at Keokuk. Mr. W. E. Praeger has three records of its occurrence in Clark Co., Mo., in the second and third week of April. The writer met with it April 12, 1894, in Lincoln Co. (Auk, vol. 12, p. 7). April and October seem to be the months, when we can expect it in Missouri. Mr. IV. W. Cooke found it wintering at Caddo, Ind. Ter., $34^{\circ} 11^{\prime}$ lat., from the middle of Norember to the end of February. Mr. Otho C. Poling of Quincy, Ill., calls it (Auk, vol. 7, p. 240) a regular spring and fall migrant, seemingly more plentiful in the fall than in the spring, sojourning from early Oetober until the middle of November, frequenting stubble fields of oats and wheat with short grass and weeds. He also found large flocks on the lowland about Lima Lake, lying closely in the short grass.

538. Calcarius ornatus (Towns.). Chestnut-collared Longspur.

Piectrophanes ornatus. Centrophanes ornatus. Emberiza ornata. Plectrophanes melanomus.

Geog. Dist.-Great Plains of North Anerica, breeding from Kansas and Colorado north to the Saskatchewan. In winter to Arizona and Mexico.

The only record of its occurrence in Missouri is that of W. E. D. Scott, who found it rather common during April, 1874, on the prairics west of Warrensburg, Johnson Co. Dr. E. Coues writes that it associates intimately with $P$. pictus, Smith's Longspur, and has much the same habits and general appearance.

[539. Rhynchophanes mccownil (Lawr.). McCown's Longspur.]

Plectrophanes mecownii.

Geog. Dist.-Great Plains district of North America, breeding from eastern Colorado and northwestern Kansas northward to plains of the Saskatchewan; south in winter to northern Mexico, Arizona, New Mexico and Texas; casual to Illinois.

The Illinois record comes from Champaign where in January, 1877, three specimens were taken with Lapland Longspurs. This species may be expected to occur as a migrant or winter visitant any time between September first and May first and 
should be looked for in western Missouri, as it has been secured several times in eastern Nebraska. Dr. E. Coues says that it has been observed usually in company with $P$. ornatus, and Dr. J. A. Allen writes: "In habits, notes and general appearance, it is scarcely distinguishable, at a little distance, from the Chestnut-collared Bunting."

\section{*510. Pooecetes gramineus (Gmel.). Yesper Sparrow. \\ Fringilla graminca. Emberiza graminea. Zonotrichia graminea. Poocetes gramineus. Bay-winged Bunting. Grassfinch. Ground Sparrow.}

Geog. Dist.-Eastern United States and more southern British provinces; breeding from Virginia and northern Wissouri northward. Winters in Southern States to eastern Texas.

In Missouri a fairly common transient visitant and a scarce or only locally eommon summer resident according to some observers in the prairie region north and west. Mr. S. S. Wilson took eggs of this species June 15, 1895, at St. Joseph; Mr. Prier says it is a very common breeder at Appleton City; Mr. E. M. Parker reports it breeding in Montgomery Co. In his list of Warrensburg bircls, made in 1874, W. E. D. Scott gives this species as breeding, but Mr. Aubrey F. Smithson's list of Warrensburg breeders, 1906, does not corroborate that statenient, neither did Mr. Chas. W. Tindall find it breeding near Independence. On the cottonfields of the southeast the first transients appear early in March; in central Missouri about March 15, in the most northern counties seldom before April. They are never very common, but may be met with in small troops along the edges of woods or timbered creeks nearly throughout April, most commonly between the 10th and 20th. In fall the bulk of transients passes through Missouri in the second half of October, though loiterers have been noted late in November (November 20 , 1902, Jasper Co., November 20, 1894, Keokuk). In Shannon Co., where Mr. E. S. Woodruff found the first, Mareh 19, none were seen after April 7.

*542a. Passerculus sandwichensis savanna (Wils.). Savanna Sparrow.

Fringilla savanna. Passerculus savanna. Emberiza savanna. Ammodramus sandwichensis saranna.

Geog. Dist.-Easterm North America, breeding from Connecticut, Pennsylvania, Ontario, northwestern Indiana northward 
to Ungava, west side of Hudson Bay, etc. Winters in the Southern States, Bahamas, Cuba. Replaced westwardly by subspecies alaudinus (Bonaparte).

In Missouri a common transient visitant from the middle of March to the first week of May and again from early in September to late in November, but chiefly in April and October. It was found breeding May 27, 1874, by W. E. D. Scott, near Warrensburg, where it was rather common in the spring of $1874 . \mathrm{Mr}$. Nehrling found it breeding at Pierce City, Mo. (W. W. Cooke), and Mr. R. Ridgway at Mount Carmel in southern Illinois, the nests being in damp meadows; he also took some there in the middle of winter. 'That Mr. E. S. Woodruff found not only the Vesper Sparrow, but also the Savanna Sparrow common on meadows at Eudy, Shammon Co., in the midst of the heavily wooded Ozark hills is interesting as it shows that even such birds usually associated with open country do not follow river valleys or certain prescribed migration routes, but fly broadcast across the land, whether high or low, wooded or open. He found the first March 19, and they became common April 28, remaining so for a whole week.

542b. Passerculus sandwichensis alaudinus (Bonap.). Western Savanna Sparrow.

Passerculus alaudinus. Passerculus savanna alaudinus. Ammodramus sandwichensis alaudinus.

Geog. Dist.-Western North America; breeding from northwestern Alaska to southern portion of Mexican tableland and from the Plains to the Pacific. In migration east to eastern Nebraska. IVinters from the valleys of the western United States and Mexico to Guatemala.

While collecting in Shannon Co. in spring 1907, Mr. E. Seymour Woodruff met with Savanna Sparrows, March 19 and 22, taking specimens which proved to be this subspecies. On May 5 he wrote that he found the species again on April 25 and considered it common on and after April 28 in meadows at Eudy, Shannon Co.

545. Coturniculus bairdir (Aud.). Baird's Sparrow.

Emberiza bairdii. Ammodramus bairdii. Centronyx bairdi. Passerculus bairdi. Centronyx ochrocephalus.

Geog. Dist.-Great Plains of North America; breeding from western Minnesota, North Dakota, eastern Montana north to 
Assiniboia and Manitoba; south during migration to Texas, New Mexico, Arizona, northern Mexico; west to eastern Washington; east to Iowa and Missouri.

Was met with in St. Charles Co., October 18, 1894 (Auk, rol. 12, p. 219), and in St. Louis Co., near Old Orchard, March 17, 1895. Was also taken by Mr. S. S. Wilson at St. Joseph, March 24 and May 25, 1895, and March 21, 1896. It is a regular spring and fall migrant at Grinnell in central Iowa (A pril 25, 1885, and March 24 to April 20, 1886; October 4 to 16,1886 ) and is probably not a very rare transient visitant in Missouri, but easily overlooked when in company with other sparrows, such as Spizella monticola along the edge of woods in March, or Savanna Sparrows, etc. along the lakes and sloughs of the marsh land in the river bottoms.

*546. Coturniculus savannarui passerinus (Wils.). Grasshopper Sparrow.

Fringilla savannarum. Fringilla passerina. Emberiza passerina. Coturniculus passerinus. Ammodramus passerinus. Ammodramus savannarum. Cricket Bird.

Geog. Dist.-Eastern United States and more southern British provinces; west to edge of Plains; north to Maine, New Hampshire, Ontario, Michigan, Wisconsin etc. Winters south of United States in Cuba, Yucatan and Gulf coast of Mexico.

In Missouri a fairly common summer resident in the prairie and Ozark border region. The first arrive in southern Missouri about the niiddle of April (carliest April 10, 1902, Jasper Co.), in northern Missouri usually after April 20 and become common during the last week of April or, in some years, only in the first week of May, when they are sometimes numerous enough to suggest the presence of transient visitants. While their singing betrays them easily in spring their silence in autumn causes them to be observed with difficulty and the dates of "last seen" vary from the latter part of August through September to Octobel: 31; there is even a record of November 15, 1902, from Jasper, but this, as well as one of March 21, 1896, from St. Joseph, must be regarded as quite exceptional. Mr. E. S. Woodruff found them common in meadows at Eudy, Shannon Co., April 25, 1907, and, finding them still present May 13, and at Grandin, Carter Co., June 3, 1907, consiclers them breeders in that region. 
546a. Coturniculus savannarum Bimaculatus (Swains.).

Western Grasshopper Sparrow.

Ammodramus bimaculatus. Coturniculus passerinus perpallidus. Ammodramus savannarum perpallidus.

Geog. Dist.-Western United States and Mexican tableland. East to Minnesota, Iowa and eastern Kansas. South to Guatemala and Costa Rica.

After comparing the Grasshopper Sparrows, which Mr. E. Seymour Woodruff captured in southern Missouri in March and April 1907, he comes to the conclusion that they are rather intermediates, but nearer to bimaculatus, "having smaller bills, more chestnut and less black on their backs than the eastern bird."

*547. Ammodramus henslowi (Aud.). Hensiow's Sparrow.

Emberiza henslowii. Fringilla henslowii. Coturniculus henslowii. Henslow's Bunting.

Geog. Dist.-Eastern United States north to New Hampshire, New York, Ontario, Wisconsin, Minnesota, ctc., breeding south to lat $38^{\circ}$, west to eastern Kansas. Winters in the southern states from Florida to Texas.

In Missouri a locally common summer resident in marshes and wet meadows, probably of general distribution throughout the prairie and Ozark border regions, but easily overlooked. It has been found nesting in damp fields in St. Louis Co. and in the marshes of St. Charles Co. It is reported as a breeder in the Mississippi river bottom along the state line from Quincy, Warsaw and Keokuk. Audubon met with it May 9, 1843, near the northwest corner of Missouri and Mr. IT. E. D. Scott found it common and breeding June 1 to 10, 1874, at Warrensburg. Mr. Chas. Tindall also found it common at Independenee. It reaches the breeding grounds in Missouri during the latter half of April and remains with us until late in October. The earliest date in spring migration is contributed by Mr. E. S. Woodruff, who took one in Shannon Co., March 19, 1907. To detect it in early spring and summer one has only to be in its haunts before sunrise, when sitting on weed stalks it utters its peculiar "sewick" incessantly until the sun is well up in the sky. It is also heard before nightfall, but during the day its song is given only at long intervals, especially on warm days and when feeding the young in the nest. Like its cousins, the Henslow's Sparrow lies very close and flies quite a distance before alighting in the tangled grass, in which it escapes by running and hiding. 
*548. Amodramus leconteir (Aud.). Leconte's Sparrow. Emberiza leconteii. Fringilla caudacuta. Coturniculus lcconteii. Geog. Dist.-Prairie marshes of Mississippi Talley and Central British Provinces; breeding from Minnesota and South Dakota to Manitoba and Assiniboia. Winters in the Gulf States, Florida to Texas; coast of South Carolina, occasionally North Carolina, Incliana, Missouri, etc.

In Missouri a regular and locally common transient visitant spring and fall. It is plentiful in the marshes of the Mississippi bottom in the latter part of September, some being still there at the end of December (December 29, 1896, Osprey), but October is the month when it is most numerous. It is again with us from the midule of March (Narch 14, 1889, male taken by Mr. O. C. Poling at Quincy) to April 20. Possibly also a rare summer resident as it was found July 26, 1887, by Mr. Brown, and in immature plumage in August by Mr. Poling. Mr. Chas. K. Worthen also noted its occurrence in summer near Warsaw. Though most of the records of occurrence are from the Mississippi bottom, the species seems to frequent also the Hissouri bottoms, as Mr. Tindall reports it common in migration at Independence. It has been repeatedly met with on stubble fields on hilly ground in St. Louis Co., which belongs to the Ozark border subregion, and is probably not entirely absent in suitable localities of the Ozark region, having been found at Fayetteville, Ark., February 28, 1885, impaled by a Shrike.

\section{[549.1. Ammodrants nelsoni (Allen). Nelson's Sparrow.] Ammodramus caudacutus nclsoni. Ammodranus caudacutus.}

Geog. Dist.-Prairie marshes of Mississippi Valley and central British Provinces; breeding from northern Illinois, Wisconsin, Minnesota, South Dakota north to Manitoba. South in winter to Gulf coast; west to Texas, and to coast of South Carolina.

It is strange that this species has never been noticed within the borders of Missouri, although quite within its geographical range. Its occurrence in migration seems certain. Its capture at Warsaw, May 8, 1879, by Mr. Worthen and at Quincy, April 26, 1889 , by Mr. Poling is recorded; also that of an adult male, October 12, 1894, in central Iowa (Auk, vol. 16, p. 277); and that of a pair on May 27, 1904, in Johnson Co., Ia., by R. M. Anderson, and a young male in company with Leconte's and Grasshopper Sparrow in eastem Nebraska, October \&, 1904. October 17, 
1881, two birds were killed by Col. N. S. Goss in the bottomland of the Neosho River near Neosho Falls, Kan., fifty miles west of our state line.

*552. Chondestes grammacus (Say). Lark Sparrow.

Fringilla grammaca. Chondestes grammica. Emberiza grammaca.

Geog. Dist.-Mississippi Valley, east of the Plains; north to eastern Minnesota, Wisconsin, southern Michigan; east to Ohio, Kentucky, Tennessee; casually to the Atlantic States and Florida. Breeds from eastern Texas northward and winters south of United States. Replaced westward to the Pacific by subspecies strigatus (Swainson).

In Missouri nowhere common, but one of our most generally distributed summer residents, not only in the prairie region but, on cultivated land everywhere, even in the narrow valleys of the Ozarks. There are a few unusually early dates as April 6, 1884, Fayette; April 10, 1898, Independence and April 10, 1892, Keokuk, but as a rule the Lark Sparrows arrive in most parts of Missouri with great regularity during the third week of April only in the most northern counties a few days later. They are prominent songsters and conspicuous birds, often seen on wagon roads taking dustbaths. After the young are grown a few families gather in a troop, and begin to roam, disappearing from their breeding stands as early as July or August. Small flocks are met with until late in September, and some observers report the "last seen" as late as October 4, 1903, New Haven and October 17, 1883, and 1885, Mt. Carmel-exceptional cases.

\section{Zonotrichia querula (Nuttall). Harris's Sparrow.}

Fringilla querula. Fringilla harrisii. Fringilla comata. Hooded Sparrow.

Geog. Dist.-Interior plains of North America, from eastern base of Rocky Mountains to Western Missouri, Iowa, Minnesota, Manitoba, occasionally to Illinois and Wisconsin. Breeds north of United States (Assiniboia) and winters in Texas.

Western Missouri with eastern Kansas and eastern Nebraska, is the main thoroughfare of this species from its summer home in Assiniboia to its winter home in the Indian Territory and northern Texas. All early explorers met with it; in 1832 Prince of Wied, who described it later under the name of $F$. comata; Nuttall and Townsend, who discovered it near Kansas City (In- 
dependence and V'estport) in 1833, were the first to describe it under the name of $F$. querula in 1840. When Audubon ascended the Missouri River in 1843 in company with Bell, Harris and Squires, he thought he found a new finch near Fort Leavenworth, May 4,1843 , and called it Fringilla harrisii, not knowing at the time of Nuttall's discovery and deseription. He met with it again on May 6, 7 and 8, when near the corner of the state. It was with Zono. lencophrys and albicollis, Melospiza lincolni, Siurus noveboracensis, Dendr. coronata and Helm. rubricapilla. Dr. Hoy met with it at Lexington, May 7,1854 , and a troop of from 15 to 20 at Chillicothe, May 13, 1854. Dr. J. A. Allen found it excecdingly abundant at Leavenworth in May, 1872, and Trippe listed it as abundant in fall and spring in Decatur, Ia., 1872. It was also taken by the Warren's Expedition at Fort Leavenworth, and Aughey gives it as common in eastern Nebraska along the Missouri River. In his Birds of Western Missouri (Nuttall Bull., Vol. 4, p. 144), W. E. D. Scott writes: "On my arrival at Warrensburg, March 27, 1874, I found the birds quite common. They were all moulting, and had much the same habits as the White-crowned Sparrows, being in small parties of three or four, and frequenting similar localities. They were still common April 27 , and had assumed the breeding plumage. I took some as late as May 5." The first week of March sems to be the time when the first make their appearance in southwestern Missouri. Earliest date, March 2, 1902, Jasper, Savage: at Independence the first date is Mareh 8, 1900, Tindall. They become common in southern Missouri during the latter part of March, and in northern Missouri in the first half of April and remain common to the end of the month or first week in May. The last are gone by the middle of May, not to be seen again until October. At St. Joseph the species was present from October 10 to November 16, 1894, according to Mr. S. S. Wilson, who took a male in spring dress, November 1. Mr. Nchrling found the species common at Freistatt, Lawrence Co., as early as October 11, 1886, but usually the bulk does not reach Missouri before the middle of October and remains to the latter part of November. A few linger well into winter, and there is a record of January 2, 1884, when the last was seen by Mr. Nehrling at Pierce City. In eastern Missouri the species is known only as a rare straggler and was met with by the writer in Lincoln Co., in the spring of 1896, and in Audrain Co., by Mrs. M. Musick of Mt. Carmel, April 3, 1884, and again April 28 to 
Nay 3, 1885. It has been obtained in the Mississippi bottom by Mr. O. C. Poling at Quiney, by Mr. Chas. K. Worthen at Warsaw, and by Mr. E. S. Currier May 3, 1898, near Keokuk.

\section{Zonotrichu LEUCOPHrys (Forst.). White-crowned Spar- row.}

Emberiza leucophrys. Fringilla leucophrys.

Geog. Dist.-United States and eastern British Provinees; breeding from Vermont, Quebee and northeastern Minnesota northwird to west side of Hudson Bay and over peninsula of Laborarlor to southern Greenland. Also throughout the high mountains of western United States southward to New Mexico and Arizona, north to inorthern California. Winters from Missouri, Illinois and southern Indiana southward to south central Mexico and throughout the peninsula of Lower California.

In Missouri a common transient visitant in all parts of the state, throughout the Ozarks as weil as in the swamps of the southeast. Some few winter even norith of the Missouri River in osage orange hedges in St. Charles Co., but more commonly in the southern part of the state, never in large numbers, but a few individuals with Tree Sparrows and Juncos, or Whitethroated and Fox Sparrows. The first stir among the hardy Fringillidae about the middle of Mareh brings also some Whitecrowns to places where we had not noticed them before, but real migration shows itself only after the middle of April, and even then it drays on until one fine morning all Missouri is resounding with their peculiar song. This occurs with great regularity between the fourth and eighth of Nay; very exceptionally earlier, as April 29 and 30, 1884. They frequent open ground, fences, hedges, ete., also the edge of woods, but seldom the woods themselves, and remain common and conspicuous for a few days only, but their song is heard and the birds seen till May 15 to 18, even in the southern part of the state (latest for St. Louis, May 20 and 22, 1907). The first fall migrants reach northern Missouri soon after the first of October, and southern Missouri in the second week of the month. The bulk is present in the third and fourth weeks, and the last transients leave us in the first half of November: 
558. 7onotrichia albicoldis (Gmel.). White-throated Sparlow.

Fringilla albicollis. Fringilla pensylvanica. Zonotrichia pensylvanica. Peabody Bird.

Geog. Dist.-Eastern North America; breeling from Massachuseits, northern New York, Ontario, northern Michigan, Wisconsiil, northern Minnesota, easterin Wyoming, eastern INIntana, etc., northward to Great Bear Lake, west shore of Hudson Bay, Laborador and Newfoundland. In winter from Massachusetts and southern New York, along the Atlantic coast to Floricla and in the Mississippi Valley from the mouth of the Missouri River to Louisiana and southern Texas.

In Missouri a very common transient visitant; one of the most numerous and unirersally distributed of migrants in spring and fall, and in southeastern Missouri one of the most numerous winter residents. In sheitered places, chiefly river bottoms, sinall numbers winter regularly in the vicinity of St. Louis, but keep very quiet until migration begins early in March. Between the tenth and twentieth the first White-throats appear in many places in central Missouri where they have not wintered. From this time to the midule of April there is not much change visible, the species being only fairly common, though comparatively prominent, because often in song. The great army of transient White-throats appears in the southern part of the state April 15, in the central April 20, and in the most northern, April 25. They are in large flocks with many individuals in high dress and full of song. Their presence in such number's lasts about eight days, after which a change is noticeable; most of the high dressed aclult birds are gone, and the flocks contain principally birds of the second year, plain dressed and not so musical. Large troops, mostly females, renain through the first week of May; small parties are also found during the second week, but after the micldle of May they are always rare if present at all. The "last seen" in the state are dated between May 15 and 20, exceptionally later, as May 2t, 1883, at St. Louis. Southward migration of White-throats reaches Missouri some years in the last days of September, but usually not before the first week of October in the north, and the second week in the south of the state. Earliest date for St. Louis, September 21, 1887; for Reokuk, September 28, 1902. Between Oetober 8 and 12 they arrive at St. Louis in large flocks, many adults in fine dress and song among 
them. They remain numerous to the end of the month, but after the twentieth the flocks contain a majority of young birds in very plain dress. After the first of November they grow scarce generally, but small parties linger even in the most northern part sometimes into the latter half of the month, exceptionally into December (Keokuk, November 18, 1902; November 19, 1893; November 20, 1892 and 1900; December 8, 1896).

559. Spizella monticola (Gmel.). Tree Sparrow.

Fringilla canadensis. Emberiza canadensis. Spizella montana. Fringilla arborea. Canada Tree Sparrow. Winter Chippy.

Geog. Dist.-Eastern North America, west to the Plains where replaced by the western subspecies ochracea; breeding in Newfoundland, Labrador and the Hudson Bay region. In winter from the northern United States southward to South Carolina, Tennessee, Indian Territory.

In Missouri a common winter resident arriving irregularly, sometimes in north Missouri as early as the second week of October (October 9, 1892 and 1894, and October 10, 1901, Keokuk; October 10, 1894, St. Joseph), in other years not before November. At St. Louis the first are seen between the 4th and 14 th of November, and are common before the month is over, moving in small flocks in search of weed seeds and coming to the farm yards when the snow is deep. Their departure is influenced much by the weather we have in March. Even warm weather in the latter part of February induces them to become exeited and musical, deserting some of their winter haunts and flocking to the bottom-land preparatory to departing. In some years they are nearly all gone by March 20th, in others flocks are with us to the middle of April (April 12, 1894, large flocks in Lincoln Co.). The "lasts" vary from March 20 to April 28 (1893, Keokuk), but fall mostly into the early part of April. (April 3, 1898, Independence; April 10, 1902, Jasper; April 10, 1874, Warrensburg; April 12, 1886, Mt. Carmel).

\section{*560. Spizella socialis (Wils.). Chipping Sparrow.}

Fringilla socialis. Emberiza socialis. Spizella domestica. Chippy.

Geog. Dist.-Eastern North America, west to the Great Plains; north to Nova Scotia, New Brunswick, Quebec and Ontario; northwest through wooded districts to Saskatchewan. Breeds 
from the pine woods of the Gulf States northward, and winters in the southern United States from Florida to eastern Texas. Replaced in the West by the subspecies $S . s o c$. arizonae.

In Missouri a common and universally distributed summer resident, mostly near human habitations, but also on the dry hill tops of the Ozarks, as well as in the Bald Cypress swamps of the southeast. March 14 to 17 is the time when the first Chippies reach their breeding stands south of the Missouri; there are very few records of earlier arrivals, as March 2, 1902, Jasper; Mareh 10, 1886, Freistatt: March 10, 1887, St. Louis. At the northeast corner of the state the specics makes its first appearance a fortnight later, the dates varying from Warch 30 to April 15, mostiy April 4 to 6 . While the forerumners reach St. Louis usually about the middle of March, Chippies are seldom numerous before the first week in April, the males appearing first, followed after four clays by the females, when the species becomes conspicuous everywhere. Transient visitants increase their numbers during the second and third week of April, at the end of which ours begin nesting. Flocking in September, they disappear from many of their summer haunts and the speeies seems scarce until migration begins in early October, when sometimes large flocks are met with during the second and third week of the month. All disappear before the month is over and Chippies are great rarities in November, when their cousins, the Tree Sparrows, appear from the north.

561. Spizella Pallida (Swains.). Clay-colored Sparrow.

Emberiza pallida. Emberiza shattuckii.

Geog. Dist.-Great Plains of North America from eastern base of Rocky Mountains to prairie distriets of the upper Mississippi Valley; breeding from Colorado, Nebraska, Iowa, Wisconsin and northwestern Illinois northward to the Saskatchewan; in winter from southern Texas, New Mexico and Arizona to Cape St. Lucas and Oaxaca.

Nothing is known of the occurrence of this species in Missouri except in the territory along the eastern and western boundary. The earliest record is that of Audubon, who met with it near the corner of the state, May 9, 1843. Mr. S. S. Wilson regards the Clay-colored Sparrows common transient visitants at St. Joseph from the middle of April to early June, and gives me the following dates: April 28, May 7 and 10 and June 17, 1894; May 1 
and 3 and June 2, 1895; April 11, April 25 and May 15, 1896. At St. Louis it is a rare transient visitant and has only been taken a fer times: September 24, 1876; April 28 and May 7, 1886, and May 10, 1904. Mr. O.C. Poling found it quite common in pastures and stubble fields near Quincy, Ill., early in May, 1887, and Mr. W. Praeger met with it near Keokuk. Trippe mentions the species as common in spring, 1874, in Decatur Co., Ia., and it is said to be an abundant migrant in Nebraska, arriving in the first week in May, remaining till June and reappearing in early September and remaining through October. There can therefore be no doubt that its apparent scarcity is only due to oversight, though it is distinguishable from other Spizellae by the conspicuous ashy collar and ashy median stripe on the crown, bordered by dark brown streaks, a dark line on the side of the chin and, besides a white line over the eye, pale brown yellowish upper parts and small size.

\section{*563. Spizella pusilla (Wils.). Field Sparrow.}

Fringiila pusilla. Fringilla juncorum. Enberiza pusilla. Spizella agrestis.

Geog. Dist.-Eastem United States and Southern Canada, west to eastern Kansas, Nebraska, Red River Valley, Lake Winnipeg and Qu'Apelle; north to southern Ontario, rarely to Quebec and Nova Scotia. Breeds from upper Georgia and South Carolina, northwestern Florida, central Alabama and Mississippi, central Texas northward and winters from southern New Jersey, Virginia, Kentucky and southern Missouri southward to Florida and Texas, occasionally further north.

In Missouri a common and generally distributed summer resident. From St. Louis southward the first singing males are heard at their breeding stands in ordinary seasons in the first or second week of March; north of the Missouri River in the third, and in the region of Keokuk in the fourth week of March. In unusually backward seasons their arrival may be retarded from one to tro weeks. The bulk of the speeies is clue from the middle of Warch in the south to the first week of April in the north. Transients in small troops are present the last of March and in early April. They sing all summer, sometimes till September, and fresh eggs were found in September. From the last week of September to the michlle of October they are found in small flocks, probably transients, while some of ours remain, associated with other sparrors, till the middle of Norember. Single indi- 
viduals are met with in winter in the vicinity of St. Louis in company of other sparrows, and small troops winter regularly in the sheltering forests of southern Missouri.

563a. Sprzella pisilla arenacea Chadb. Western Field Sparrow.

Spizella arenacea.

Geog. Dist.-Breeds from Nebraska and South Dakota to eastern Montana: winters in southern Texas, Louisiana and northem Mexico.

Of the four specimens which Mr. E. Seymoul Woodruff collected in Shannon Co. in Narch, 1907, he found "two to be undoubted arenacen, the other two intermediate between pusilla and arenacea but nearer the latter, because of their longel wings and tail and general paleness."

567. Junco himemals (Limn.). Slate-colored Juneo.

Fringillahyenalis. Struthushyenalis. Tipheahyemalis. Junco hiemalis. Fringilla nivalis. Junee. Snowbirl.

Geog. Dist.--Eastern North America and through the interior to the Arctic coast and Alaska; breeding from the mountains of Pennsylvania, New York and Massachusetts, from Ontario, central Michigan, northern Wisconsin, northern Minnesota northward to Labrador, western shores of Hudson Bay, to the Arctic coast and the valleys of the Yukon and Kowak. Winters from Comnecticut, southem Vichigan, Wisconsin and eastern Nebraska southward to the Gulf const, Arizona and California.

In Missouri a very common winter resident and transient visitant, present fully one-half of the year. The first, exceptionally early arrivals, have been noted at Keokuk, September 11, 1894, and September 25, 1899; at St. Louis, September 20 and 26, but usually the van does not reach Missouri before the first week of October and St. Louis in some years not before the end of the second week. The main body of the invading army comes to our northern border in the second week of October, to St. Louis about October 20th and to the southeastern corner of the state about the last of the month. Transients throng the state until the middle of November, after which winter numbers remain. As the northern limit of their range varies in different seasons, so 
does the number of wintering individuals. In hard winters when the snow is deep and hard they are driven to the farmyards for food and shelter; but for this protection many would perish by cold or starvation, especially in regions where their former refuge, the forests, no longer exist. Spring migration from the south begins often as early as the last week of February, certainly by the tenth of March, and is at its height from the middle to the last of the month, when most old birds are gone and mainly young ones are present mostly in silent flocks. These, too, pass on during the first half of April and stragglers only are left in the latter part of the month. In some years, when spring was exceptionally late or cold, individuals have been seen at St. Louis in May and as late as May 24 and May 29, 1882, but as a rule the clates of "Juncos last seen" range from April 10 to 30 all over the state.

An exceptionally late date is reported by Mr. E.S. Woodruff, who took a Junco at Grandin, Carter Co., May 21, 1907, saying: "But this can be explained by the fact that he was a diseased bird infested by parasitic worms. His stomach was distended to twice the normal size and was just one solid mass of transparent worms, 3 inches or more long, filling up every bit of space around the organs and intestines." Last Junco in 1907 at St. Louis was seen May 4.

567b. Junco hyemalis connectens Cones. Shufeldt's Junco. Junco hyemalis shufeldti.

Geog. Dist.-Rocky Mountain region, west in the mountains of the Great Basin to eastern California; in winter to Arizona, New Mexico, Texas and northern Mexieo. Accidental in Nebraska, Illinois, Michigan, Indiana, Massachusetts and Maryland, but with difficulty distinguished from Montana Junco, Junco montanus, which in winter also straggles eastward from its breeding grounds in Montana, Idaho and northward to Alberta.

This subspecies is entered in our list as of probable occurrence on the strength of a specimen taken by Mr. Wm. E. Praeger near Keokuk, Ia., Deeember 16, 1892, from a floek of common Juncos. It may be not an uncommon, perhaps regular, winter visitant to some parts of Missouri, particularly the western, and colleetors should pay special attention to the identification of Juncos. 
567.1. Junco montanus Ridgway. Montana Junco.

Geog. Dist.-Breeds from northwestern Montana and northern Idaho to Northwest Territory and Alberta. In winter to Arizona and northern Mexico, western and middle Texas, etc. In migration east to Mississippi Valley; casually to Massachusetts, Maryland etc.

The Juncos collected by Mr. E. Seymour Woodruff in Carter and Shannon Counties in March and April 1907, Dr. Dwight divided into three races: hyemalis hyemalis, hyemalis connectens, and montanus. The typical hyematis he also found to differ somewhat from eastern birds, resembling those which breed in the western part of their range, i. e., Alaska.

\section{*575a. Peucea aestrilats Bachmanil (Aud.). Bachman's} Sparrow.

Fringilla bachmanii. Peucea bachmanii. Peucea aestivalis. Peucea illinoensis. Peucea aestiralis illinoiensis. Aimophila aestivalis bachmanii. Oakwood Sparrow.

Geog. Dist.-From South Carolina and northern Georgia and the Gulf coast west of Florida north to southern Virginia, Maryland, southern Ohio, Indiana, Illinois and southeastern Iowa; west to western Missouri and middle Texas. In winter to Florida.

In Missouri a rare summer resident, reported first by Mr. H. Nehrling from Pierce City, Lawrence Co., in 1884, as not common, and by Mr. O. C. Poling from the Mississippi bottom in Marion Co., Mo., where from about May 1 to 5, 1889, he observed two in a clearing among scrub oak and brush. Early in May 1887 the same gentleman collected three specimens in an old apple orchard at Quincy, Ill. Mr. IV. G. Savage reported their occurrence at Monteer, Shannon Co., in 1906, and Mr. E. S. Woodruff verified this report by taking specimens at Ink, Shannon Co. on March 19, March 31 and April 5, and writes, May 5, 1907: "These are very common birds here and breeding." On May 17,1907 , he saw one and heard the song of two others near the Current River in Carter Co. Perfect proof of its breeding in the state was furnished by Mr. E. S. Woodruff when he found a nest in Carter Co. near the line of Reynolds Co., May 27, 1907. He wrote me under date of June 2, 1907: "The nest was on the ground in a clump of grass and New Jersey Tea (Ceanothus 
americ.) in oak and pine woods from which the pine had very recently been cut. It contained two eggs of Bachman's Sparrow and three of Cowbird-incubation far advanced. The nest was near (10 feet) the top of a recently cut pine. I mention this, for I invariably find Bachman's Sparrows about the dead tops of fallen trees."

*581. Melospiza cinerea melodia (Wilson). Song Sparrow.

Fringilla fasciata. Melospiza fasciata. Melospiza melodia. Fringilla melodia. Emberiza melodia. Melospiza meloda.

Geog. Dist.-Eastern United States to the Plains; north to the Maritime Provinces, Quebec, Ontario, Miaritoba, Saskatchewan and Alberta. Breeds from Virginia, southern Indiana, northern Kentucky, central Mississippi, southern Missouri and Kansas northward, and winters from Nova Scotia, the Great Lakes, and Nebraska southward, but chiefly south of the Ohio River.

In Missouri a common and generally distributed transient visitant; a fairly common winter resident and a rather rare, only locally common, summer resident in the alluvial bottoms and prairie region from Ste. Genevieve and Jasper Co. northward, increasing in numbers and spreading to new territory. The Song Sparrow is one of the very first to stir from its winter quarter's as soon as the backbone of our Missouri winter is broken, commonly near the end of February. It is then scen at places not frequented before, but these movements are only preliminary to the great general advance which begins about March 10 and gathers full strength at the middle of the month, when the great mass occupies the state from one end to the other and holds possession of it for three weeks, until the second week in April, being more numerous southward in March and northward in April. The last transients leave southern Missouri about the middle, northern toward the end of April; and birds heard singing in May should be marked probable summer residents. Fall migrants begin to arrive the middle of September, but do not become numerous before October, sometimes early in the month, sometimes not before the latter part, remaining common into November, but seldom into the second week, after which winter numbers only are left. 
583. Melospiza lincotni (Aud.). Lincoln's Sparrow.

Fringilla lincolnii. Pcucea lincolnii. Zonotrichia lincolni.

Geog. Dist.-Central and North America from Panama to the northeastern coast of Labrador and Fort Yukon in Alaska. Breeds from northern Illinois and northern New York northward, and in the higher mountains of the United States south to Mt. Whitney in the Sicra. Winters from our southern states southward to Panama.

In Missouri a fairly comnon transient visitant in all parts of the state; never in flocks, but associated with other sparrows, chiefly Melospizae and Zonotrichiae. Due to its southwestnortheast migration it appears first in the southwestern part of the state from where it is reported in March (Narch 7, 1901, Iberia, March 13, 1885, Freistatt); the first individuals secm to reach northem Missouri and southern Nebraska carlicr than the region of St. Louis, being reported from Mt. Carmel and Keokuk, April 5, and in Nebraska in the second week of April. At St. Louis the Lincoln's Sparrow arrives pretty regularly between the 20th and 25th of April, rarely a few days later. It is most common all over the state from the second to the twelfth of May, and the last are seen soon afterward, varying in different years between the tenth and sixteenth, except in unusually cold springs, when the last remained to May 23, 1904, and Nay 28, 1897. The first reappear in fall early in October (earliest October 5, 1859, Independence); at St. Louis about October 7, followed by the bulk a few days later, present generally from the 10 th to 15 th, and the last are noted near the end of the month, seldom remaining into November (November 4, 1900, Keolsuk, Currier).

*584. Melospiza georglana (Lath.). Swamp Sparrow.

Fringilla georgiana. Fringilla palustris. Zonotrichia palustris. Ammodramus palustris. Melospiza palustris.

Geog. Dist.-Eastern North America, north to Newfoundland, Labrador and Athabaska; west to about 100 meridian in $\mathrm{Ne}$ braska. Breeds from southern New England, northern Indiana, northern Missouri and eastern Nebraska northward. Winters from southem New England, southern Illinois, Missouri and Kansas southward to the Gulf.

In Missouri a common transient visitant, found in varying numbers in all parts, high and low, but most abundantly 
in the flood plain of the Mississippi River. A few remain in winter north of the Missouri River, more in southern Missouri, especially the southeast. According to some observers the species is also a rare breeder north of the Missouri River. Mr. Philo IV. Smith, Jr., reports that he found a nest with young, June 2, 1905, near Maple Lake in St. Charles Co., and Mr. E. M. Parker has found it nesting near Montgomery City. Mr. E. S. Currier thinks a few nested at Sand Ridge near Wayland, Clark Co., Mo. W. E. D. Scott also says it possibly breeds at Warrensburg where he took some as late as May 25, 1874. Trippe writes: "Breeds in small numbers in Decatur Co., Ia.," (the border county north of central Missouri). As is the case with several other species of sparrows wintering in the southern states, migration commences in an undecided way, some advancing in short steps toward the breeding grounds in the north as soon as absence of snow and ice allows. In some years this is possible at the end of February, in others nearly a month later, but the middle of March may be taken as the average time for the first arrival of small troops of transient Swamp Sparrows in the vicinity of St. Louis and a week later in the marshes of Clark Co. in the northeast corner of the state. The bulk of the species leaves southeast Missouri about the middle of April, is present in the central part from April 10 to 20 , and at the northern border from April 16 to 26 . The last ones are sometimes noted in the last week of April, but just as often in the first week of May, less commonly later (May 11, 1882 and 1886, St. Louis; May 13, 1907, Shammon Co, Woodruff; May 23, 1899, and May 27, 1901, Keokuk). September 27 is the first day when transients were observed in central Missouri and October 1, 1886, in Lawrence Co., southwest Missouri. The earliest date at Keokuk, reported by Mr. Currier, is September 11, 1894, the next earliest September 26, 1899. The bulk enters the state about October 10 , has spread over central and western Missouri by the middle of the month and remains to the end or to the first week of November. After the middle of November winter numbers only are left.

585. Passerella iliaca (Merr.). Fox Sparrow.

Fringilla iliaca. Fringilla ferruginea. Zonotrichia iliaca. Fringilla rufa.

Geog. Dist.-Eastern North America, north to Newfoundland, Anticosti, southern Labrador, northwestward to Alaska. Breeds 
from northern Maine, northern Nanitoba and Alberta northwarel. Winters from Potomac, Ohio and Missouri Rivers southward to the Gulf coast and westward to middle Texas.

In Missouri a common transient visitant in all parts of the state, and a fairly common winter resident fron St. Louis southward, particularly numerous in the heavy forests of the swampy southeast. They are among the first sparrows to leave their winter quarters in the southern states, but make slow progress at first. Entering the state at the southern boundary late in February or early in March the first reach central Missouri in the second, the northern border in the third week of the month. The buk is present southwardly from the midlle to the end of Mareh, northwardly from the 20th to April 5, sone years to the 10th. The last birds are observed in the first and second week of April, rarely later. Latest records April 17, 1894, Keokuk; April 18, 1903, and 19, 1888, St. Louis. In withdrawing from the northern breesling grounds Fox Sparrows are among the latest migrants to put in their appearance in Missouri, where they are seldom seen before the second, some yoars not before the thire, week of Oetober. Earlier, execptional, dates are reported from Kookuk, September 29, 1896, October 1, 1895, October 2, 1894. They are most common in all parts of the state between October 25 and November 10, but retire southward by the midlde of the month; latest dates November 20, 1894, Keokuk; November 25, 1902, Jasper; December 10, 1901, .Tasper.

*587. Pipilo erythrophthalmus (Limn.). Towhee.

Fringilla erythrophthalma. Emberiza erythrophthalma. Chewink. Joree.

Geog. Dist.-Eastern North America north to Ontario and eastern Manitoba; west to eastern Dakotas, Nebraska, Kansas, Indian Territory. Breeds from Georgia and Louisiana northward and winters from Pennsylvania, Indiana, Missouri and eastern Kansas southwarl to southern Florida, the Gulf coast and southwestern Texas.

In Missouri a common summer resident in the prairie and Ozark border region, but only locally common in the Ozarks, and rare in the swampy southeast, where it is a fairly common winter resiclent. As a transient visitant it is generally distributed and common from the middle of March to the midclle of April, and from September 25 to October 20. As a winter resi- 
dent it is rare in northern Missouri, but becomes more numerous as we approach the southern boundary, chiefly southeast. The first Towhees return to their breeding stands in the southern part before the middle of March, to the northern part chiefly after the middle of March. In the vicinity of St. Louis March 17 is often the day when their song is heard for the first time at most of their stands, meaning that the bulk of males has come and is taking possession of their former haunts, awaiting the arrival of the females. This takes place generally within one week and the species is conspicuous, noisy and mating, before the end of the month. Their ranks continue to fill up, and many transients in small troops are present, during the first half of April, while some of the first comers have already begun nest building, and eggs may be found by the first of May. In the latter part of September the Towhees begin to flock and are heard to sing again. Migration from the north sets in soon after the first of October and lasts till about the 20th, being most brisk about the middle of the month, or a few days before. After the 20 th the species rapidly approaches winter numbers.

*593. Cardinalis cardinalis. (Limn.). Cardinal.

Loxia cardinalis. Fringilla cardinalis. Pitylus cardinaiis. Guinace cardinalis. Cardinalis virginianus. Redbird. Kentucky Cardinal.

Geog. Dist.-Eastern United States, north to southeastern New York, the Great Lakes, southern Iowa, southeastern South Dakota; west to eastern Nebraska, Kansas, Texas. Breeds from Georgia, Alabama, Mississippi, etc. northward, being replaced farther south by the Florida and Louisiana subspecies. Mainly non-migratory, but said to extend its range from year to year.

A common resident in all parts of Missouri, very common in most of southern Missouri, the Ozark region as well as the prairie and swamp lands. One of the few species of which many indivicluals are truly permanent residents, remaining on the same ground summer and winter. They are mainly old pairs which risk wintering in places where few other birds find lood and shelter, having for neighbors sometimes only the Carolina Wren and Tufted Tit, the ground being too bleak even for Blue Jays and Woodpeckers. But not all Redbirds are thus attached to their summer haunts; the majority retire to sheltered woods in the bottomland, or to nooks and corners on warm hillsides, 
where cornfields with corn on the stalk or in shocks are not far away, and where they are found when nothing else is accessible. The Reabird begins singing the middle of February, if it has not done so earlier, and keeps it up until molt begins in the latter part of August, when only the first attempts of young birds are heard in September. At this period, and until the molt is over in the middle of October, the species is unusually shy and sechusive, but on fine days in the latter part of October, and in fact sometimes even in winter, its song is as lively as in spring.

*595. Zamelodia lunoviciana (Limu.). Rose-breasted (Frosbeak.

Loxia ludoviciana. Guiraca ludoviciana. Fringilla ludoviciana. Coccoborus ludovicianus. Hedymeles ludovicianus. Goniaphea ludoviciana. Habia ludoviciana. Loxia rosea. Coccothraustes ludovicianus. Rosebreast. Redbreast.

Geog. Dist.-Wastem United States and southern Canada; breeds from New Jersey, Pennsylvania, northern Ohio and Indiana, central Illinois, Missouri and eastern Kansas northward to Nova Scotia, Ontario, Manitoba, Assinibnia and Alberta. In winter south of the United States to Cuba, Jamaica, Nexico, Central Anerica, Ecuador and Colombia.

In Missouri a common summer resillent in the prairie and Ozark border region, chiefly north of lat. $38^{\circ}$ and oecurring only sparingly in the valleys of the northem slope of the Ozarks, from Ste. Gencvieve and Iron Counties to Lawrence and Jasper Counties. On the southern slope of the Ozarks and in western Missouri south of lat. 370 it is entirely replaced in the breeding season by the Blue Grosbeak. In the alluvial counties of the southeast it is rare, but has been found once in summer on an island near the southern boundary of Dunklin Co. The most southern record of nesting in southwest Missouri has been furnished by Mr. Nehrling, who observed a young bird with its parents July 6, 1885, near Freistatt in Lawrence Co. In unusually favorable seasons the first Rosebreasts have made their appearance at St. Louis as early as April 18 and 20, but the majority of dates range between April 22 and 29 , for first males, followed a few days later by the females. Birds of the second year come with the bulk of transient visitants, which pass through Missouri during the first week in May, when they are found in regions where they do not breed (Shammon Co., May 2, 1907, 
Woodruff). At the end of summer the Rosebreasts are met with in small troops, but in the river bottoms where they roost in the willows, gatherings of from 30 to 50 may be found about the middle of September, probably transients in passage. At the end of September these flocks have departed, but small family groups do not think of leaving certain favorite stands, where food is plentiful and where they are not molested; frequent visits to these places reveal their presence into the second week of October, and the last on record in the eity of St. Louis is October 18, 1906.

*597. Guiraca Caerulea (Linn.). Blue Grosbeak.

Loxia caerulea. Fringilla cacrulea. Goniaphca caerulea. Coccoborus caeruleus.

Geog. Dist.--Southern part of eastern United States, north to Pennsylvania, New Jersey, Kentucky, Missouri, Kansas, being replaced farther west by the western subspecies lazula. In winter to Cuba and Yucatan.

In Missouri a fairly common summer resilent on the southern stope and western border of the Ozarks, chiefly from lat. 370 southward, but also reported as fairly common at Jasper, Jasper Co., by Walter Giles Savage, and possibly occurring even farther north to lat. 38० 30' in Cass Co., as it was found breeding in 1901 at Osawatomie, Miami Co., Kan., only a few miles west of the state line. The Blue Grosbeaks arrive in Missouri the latter part of April (April 24, 1904, Shannon Co., Mr. IV. G. Savage) and remain till October (October 2, 1902, Jasper; October 5, 1904, Shannon Co.).

*598. Cyanospiza cranea (Limn.). Indigo Bunting.

Tanagra cyanea. Passerina cyanea. Hringilla cyanea. Spiza cyanea.

Geog. Dist.-Eastern United States and southern Canada, north to Maine, Minnesota; west to castern Kansas, and in Nebraska to the 98th meridian. Breeds from the Gulf northward and migrates through eastern Mexico and Central America to Veragua.

In Missouri one of the commonest and most universally distributed summer residents. The first arrive at the southern boundary the middle of April; at St. Louis the earliest dates are April 18 and 21, migrants in the Mississippi bottom. At its breeding stands it does not appear before from the 24th to the 
29th in most parts of southern Missouri, and the last of the month, or more commonly in the first week in May, in northern Missouri. The females are always a fer days behind the males, and full numbers, including birds of the second year in not yet fully matured clress, are not present before the middle of May. Transients, particularly small troops of singing males, swell their numbers in May, when the species is one of the most conspicuous among songsters. Exceptionally, a pair has been seen feeding young unable to fly as late as September 12, 1905, but as a rule the species has left the breeding grounds at the end of August and retired to out-of-the-way places to molt, at which period the males present a curiously spotted appearance. Transients in flocks, all in brown, are with us in the bottoms rarly in September, and birds in different stages of molt are numerous to the end of the month, but are gone soon after the first of October, though occasionally found in large numbers to the second week of that month. In especially favored localities some have been known to linger even longer. Latest for St. Louis, October 17,1885 .

599. Cranospiza anoena (Say). Lazuli Bunting.

Emberiza amoena. Fringilla amoena. Spiza amoena. Passerina amoena.

Geog. Dist.--Western United States and British Columbia: north to Idaho, Montana; east to South Dakota, western Nebraska, western Kansas; in winter to Mexico.

This species must be regarded as an accidental visitor to Missouri, though mentioned by G. S. Agersborg as oceurring in summer and probably breeding in eastem South Dakota (Auk vol. 2, p. 281), and has been taken twiee in eastern Nebraska east of the 97 meridian. It enters the list of Missouri birds on the strength of two specimens, a male and a female, taken at St. Joseph out of a flock of young birds, September 13, 1894, by Mr. Sidney S. Wilson.

[601. Cranospiza ciris (Linn.). Painted Bunting.]

Embcriza ciris. Passerina ciris. Fringilla ciris. Spiza ciris. Nonpareil. Painted Finch. Pope.

Geog. Dist. - South Atlantic and Gulf States to western Texas; north to North Carolina, southern Illinois, southern Kansas. In winter to Bahamas, Cuba, Mexico, Central America to Veragua; west in transit to Arizona.

No record at present of its occurrence in Missouri, but search 
along our southern border will probably reveal its presence as a rare summer resident in the valleys leading up from the south. The species has been observed by Mrs. L. MeG. Stephenson at Helena, Ark., and by Mr. Philo WV. Sinith Jr., at Eureka Springs, Ark.

*604. Spiza americana (Gmel.). Dickcissel.

Emberiza americana. Fringilla americana. Euspiza americana. Blackthroated Bunting.

Geog. Dist.--United States east of Rocky Mountains, north to Massachusetts, southern Ontario, Michigan, Wisconsin, Minnesota, North Dakota; now extinct east of Alleghany Mountains; breeds from Alabama, Mississippi, Texas, northward and winters south of United States, migrating through New Mexico, Arizona, Mexico (both coasts) and Central America to Columbia and Trinidad.

In Missouri a common summer resident in the prairie and Ozark border regions; rare in the Ozarks where only in open, long settled localities; sparingly on the cultivated ridges of the southeast. The first arrive nearly throughout the state during the fourth week of April, at least the forerunners do, impatient males which want to reach their old haunts before rivals arrive. Females do not appear before the first week in May, and the great mass of the species, including the young of last year, comes only during the second week of the month. Transients may be seen flying over in the early morning from the last clays of April to May 20, some following the prairie region going east, others, coming from the south, cross the heavily wooded part of Missouri in a northerly direction. The first brood is able to take care of itself by July 1, but we sometimes see parents feeding young after the middle of August. When the breeding season closes, families gather into small flocks and are seen flying south in the early hours of the day from August 20 to September 10. To the general observer the species is rare after the middle of September, but for one who knows the roosts the last has not gone before the first of October.

605. Calamospiza melanocorys Stejn. Lark Bunting.

Fringilla bicolor. Calamospiza bicolor. Corydalina bicolor. Dolichonyx bicolor.

Geog. Dist.-Great Plains between Missouri River and Rocky Mountains; breeding from middle and western Kansas, eastern 
Colorado, western Minnesota to Manitoba and Assiniboia; migrating south and southwest through Texas, New Mexico and Arizona to plateau of Mexico, Lower California and coast of southern California.

In his Journal of an Exploration of western Missouri in 1854, Dr. P. R. Hoy lists the Lark Bunting, Dotichonyx bicolor, among his 153 species of birds observed between April 16 and June 15. Under date of May 30, 1854, he writes: "On the way I saw the only prairie reed bird (Dolichonyx bicolor) I ever met. I followed it in full chase, under a hot sun, at least two miles before I shot it. Although greatly fatigued I was well satisfied at my final success in obtaining the much coveted bird." This was near the state line, while driving north from Sugar River on the old military trail (Linn Co., Kan., and Bates Co., Mo.). Audubon found it in Harrison Co., Ia., where Bell shot two males May 13, 1843. It has also been taken in Nebraska within fifty miles of Missouri at Beatrice and Lincoln, and is mentioned as a common summer resident in the southeastern corner of South Dakota by G. S. Agersborg (Auk vol. 2, p. 281).

Family Tanagridae. Tanagers.

*608. Piranga erythromelas Vicillot. Scarlet Tanager.

Pyranga erythromelas. Tanagra rubra. Pyranga rubra.

Geog. Dist.-Eastern North America north to the Maritime Provinces, northern Ontario, Manitoba, eastern Assiniboia; west to eastern Kansas, Nebraska, rarely to Wyoming and Colorado. Breeds from Virginia, Kentucky, southern Missouri northward; in winter to the West Indies and through Mexico, Central America and northern South America to Bolivia and central Peru.

In Missouri a fairly common summer resident in the woods of the prairie and Ozark border region; frequent in the valleys of the Ozarks into northern Arkansas, but rare in the southeast (Mr. B. T. Gault found it breeding in Heburn, Ark., in 1888 and Mr. Philo W. Smith, Jr., writes that, it was fairly common in the vicinity of Eureka Springs in the summer of 1906, where he found the Summer Tanager strangely absent). The first reach southeastern Missouri in the third week of April, central Missouri in the fourth, and the northern border in the last days of the month or early in May. Females come a few days after the 
males and it is generally May 3, when the song of the Scarlet Tanagers becomes common in the neighborhood of St. Louis. When their song ceases in July the bird becomes retiring and their presence is often only indicated by their peculiar call note. About the middle of September they become prominent once more in their traveling dress migrating with troops of northern warblers leisurely through Missouri. They are thus met with occasionally to the end of the month, but loiterers are seen not rarely in October, as October 6, 1905 and October 14, 1906 (St. Louis).

*610. Piranga rubra (Linn.). Summer Tanager.

Tanagra aestiva. Pyranga aestiva. Pyranga mississippensis. Summer Redbird.

Geog. Dist.-Eastern United States, north to New Jersey, Pennsylvania, Ohio, central Indiana, central Illinois, southern Iowa, southeastern Nebraska; casual northward. In winter to Bahamas, Cuba, eastern Mexico, Central America, northern South America to Peru.

In Missouri a common summer resident in the Ozark and Ozark border region; fairly common in the prairie region, becoming scareer as the northern border is approached. Mr. E. S. Currier considers it a very rare summer visitor at Keokuk and never found it breeding. Mr. S. S. Wilson took a male at St. Joseph, May 4, 1895, and saw one June 12, 1896. Audubon saw it at Fort Leavenworth, May 4, 1843. The first arrive in their haunts on the sunny hillsides of the Ozarks in the third week of April; in the Ozark border region of St. Louis Co. in the fourth week or, if the weather should be unfavorable, only at the end of the month or early in May, when they usually become common. Both species of Tanagers often occur together in the same woods, but as a rule the Summer Tanager prefers the hills, while the Scarlet Tanager takes to the timber in the river bottoms. This species is also much more likely to become reconeiled with modern conditions and makes its nest in the trees of villages and suburbs and partakes of our hospitality in the orchard and vineyard. They remain with us to the latter part of September and not a few linger into October (October 5 , 1904, Shannon Co.; October 5, 1906, St. Louis). 


\section{Family Hirundinidae. Swallows.}

*611. Progne subis (Limn.). Purple Martin.

Hirundo subis. Hirundo purpurea. Progne purpurea. Martin.

Geog. Dist.-United States (except Pacific coast) and southern Canarla, north to Maine, New Brunswick, Nova Scotia, Ontario, Manitoba, Saskatchewan, Alberta and Vaneouver, B. C. Breeds from southern Florida and southern Texas, and plateau of Mexieo northward, and winters from southern Florida and Mexico to Venezuela and Brazil.

In Missouri a eommon and generally distributed summer resident in cities and towns and on many farms wherever boxes or nesting sites are found; most abundant in old towns along rivers. The first Martins arrive in southern Missouri in the second week of March, at St. Louis in the third, and in northern Missouri in the fourth week of the month. Inerease is slow and the bulk of the species has not come before a month later, while birds of the second year are not in full numbers before the mirldle of May. As soon as the young are able to fly the distance, the whole family goes to the common roost and Martins become searce at their breeding places about the middle of July, when all the young are on wing. On their favorite hunting grounds and especially at the roosts in the willows on the banks of the Mississippi, Martins are present and numerous until the middle of September, after which only stragglers are left. Last date at St. Louis September 24. Migration from the north sots in about the middle of August and from August 24 to September 10 extraordinary numbers go to the common roosts in the willows (See Forest and Stream, vol. 23, no. 10). Though English Sparrows are said to drive the Martins away, no deerease is noticeable in Missouri, and with a little help from us English Sparrows ean easily be kept out of Martins' houses. For" an account of "How Young Martins are fed" see Forest and Stream, vol. 22, no. 25, reprinted in vol. 1, p. 6 of the Audubon Magazine, July 1887.

*612. Petrochelidon lunifrons (Say). Cliff Swallow.

Hirundo lunifrons. Hirundo republicana. Hirundo fulva. Eave Swallow.

Geog. Dist.-North America north to Cape Breton, Antieosti, Godbout; in the interior to Mackenzie and Yukon Valley, and on the Pacific coast to British Columbia; breeding nearly 
over the whole United States (except Rio Grande Valley and northwestern Mexico). In winter through Mexico and Central America to Honduras, possibly to Brazil, Paraguay, Argentina, etc. Rare south of Potomac and Ohio Rivers; no record from Florida and the West Indies.

In Missouri the Cliff Swallow is a summer resident of only local occurrence and not as numerous as it formerly was. At breeding stands where traces of thousands of former nests are to be seen, as for instance on the ledges above Elk River near Noel in McDonald Co., none are left. In localities where twenty years ago hundreds of nests were seen on barns, none are seen. Prejudice and eruel delight in destroying the nests at the time of incubation or when feeding young have done it. The arrival in spring takes place in the second half of April and early May, when they begin at once to build their mud-nests. The only time when the species is present in great numbers is from the middle of August to the middle of September. At this period of southward migration thousands and thousands gather at night at the common roosts in the Spartina marshes of north Missouri. All are gone before the end of September (In the Spartina with the Swallows, by O. Widmann. Bird-Lore, vol. 1, p. 4, Aug. 1899).

*613. Hirundo ervthrogaster Bodd. Barn Swallow.

Chelidon erythrogastra. Hirundo rufa. Hirundo horreorum. Hirundo americana. Hirundo rustica.

Geog. Dist.-North America, north to Newfoundland, Labrador, Ungava, the Northwest Territories and Alaska; breeding over whole of United States (except Florida) and through central and western Mexico; in winter from southern Florida and southern Mexico through Central and South America to southern Brazil, Paraguay, Argentina, Bolivia, Peru, West Indies.

In Missouri a summer resident of general distribution, but nowhere common. It is found in the state from early in April to the middle of October (earliest April 3, 1903, Currier, Keokuk; latest, October 14, 1905, Horse Shoe Lake, St. Charles Co.). The ranks of breeders fill up slowly and troops of transients have been noticed as late as the middle of May. The species is most numerous in fall migration, when large flocks gather in the marshes and roost in the reeds of lakes. As a breeder the 
Barn Swallow is more common northward than southward, in the prairie region oftener than in the Ozarks and rare in the southeast.

*(i14. Irldoprocne Bicolor (Vieill.). Tree Swallow.

Hirundo bicolor. Tachycineta bicolor. Hirundo viridis. Wood swallow. White-bellied Swallow. White-belly.

Geog. Dist.-North America, north to Newfoundland, Labraclor, Ungava, Mackenzie and Alaska; breeding from Virginia, Mississippi and Kansas, Colorado, Utah and California northward and wintering from the South Atlantic and Gulf coasts southward to Bahamas, Cuba and over Mexico to Guatemala.

In Missouri a scarce summer resident in the bottoms of large rivers as far south as the southern border of Dunklin Co., but more commonly northward. The first arrive the middle of March and the last are with us till the end of October. Transients are with us in small troops in spring from March 15 to May 15, and in large flocks of many thousands in the Mississippi bottom from the middle of September to the middle of October, after nearly all the other swallows are gone (October 28, 1885, Fayette, Howard Co.; October 31. 1899, Keokuk, Currier).

*616. Riparia riparia (Linn.). Bank Swallow.

Hirundo riparia. Cotyle and Cotile riparia. Clivicola riparia. Sand Martin.

Geog. Dist.-Northern Hemisphere; in America breeding from Georgia, Louisiana, Texas, Arizona and northern Mexico north to the aretic region. In winter through Mexico, Central and South America to eastern Peru and Brazil, also ITest Indies.

In Missouri chiefly along the Mississippi and Missouri Rivers, breeding in smaller or larger colonies, either directly over the water on the banks or over quarries, in railroad cuts, etc., on the bluffs sometimes a mile or more from the river. They are among the latest swallows to arrive at their breeding stands, seldom before the fourth week of April (earliest April 21, 1883 and 1887, St. Louis) and are generally not building in large numbers before the fifth of May. Young and old collect in immense flocks in the river bottoms as early as July 1, scattering while 
feeding and gathering at the roosts in the evening, some with the Cliff Swallows in the marsh, others with the Martins in the Willows. Migration seems to be well under way by the first of August, keeps up during the whole month and in early September, but the last are gone by the middle of the month, departing with their roost-fellows, the Martins and Cliff Swallows.

*617. Stelgidopterix serripennis (Aud.). Rough-winged Swallow.

Hirundo serripennis. Cotyle serripennis.

Geog. Dist.-From Costa Rica to Connecticut, central Massachusetts, southeastern New York, Ontario, northern Indiana, southern Wisconsin, southern Minnesota, North Dakota, Montana, British Columbia; breecls from Georgia, Louisiana, Texas and Vera Cruz northward and winters south of United States.

In Missouri a fairly common, generaliy distributed summer resident, never in large colonies like the Bank Swallows, but often in their colonies, or in single pairs or a few pairs near each other, scattered along creeks and rivers in all parts of the state, perhaps most numerous in the Ozark and Ozark border region and the bluffs of the larger rivers. They are among the earliest of this family to arrive at their breeding stands, where the first are seen in southern Missouri in the second week of March (March 10, 1902, Festus, Jefferson Co.), at St. Louis soon after the midclle, and at the northern border before the end of the month. Like other swallows their ranks fill up slowly, and it is fully a month before all have returned to their wonted haunts about bridges, railroad euts, ravines, old quarries, out buildings, etc., always, if possible, not far from water. Flocks are found in August from sixty to a hundred or more, adults and young, mostly the latter, resting together for hours on dead trees or brush on the banks of lakes or rivers, feeding together, keeping and moving together until the time for departure has come. From most of their haunts they are gone by the middle of September, but not so from the Mississippi bottom in St. Charles Co. where they remain into October, even into the second week of the month, the last, a troop of one hundred, being still present October 13, 1905, at one of their places of rendezvous at Horse Shoe Lake, an old bed of the Cuivre River. 
Family Ampelidae. Waxwings etc. Subfamily Ampelinae. Waxwings.

618. Ampelis garrulus Limn. Bohemian Waxwings.

Bombycilla garrula. Bohemian Chatterer.

Geog. Dist.-Northern parts of Northern Hemisphere, breeding in coniferous forests of the Boreal Life Zone; in winter irregularly southward; in America to Comnecticut, Pennsylvania, Ohio, Indiana, Illinois, Missouri, Kansas, Colorado, northern California; breeding from Fort Churchill in Kewatin and from Athabasca and western Alberta to Alaska.

In Missouri a very rare winter visitant as far as known at present. One killed near New Haven, Franklin Co., in November, 1858, is in the collection of Dr. A. F. Eimbeck. Another was killed in Platte Co, by Mr. John A. Bryant of Kansas City. Mr. IV. E. Pracger writes that two were shot out of a flock near Keokuk, December 27, 1896. Mr. Chas. K. Worthen writes that at Warsaw, Ill., specimens were taken and small flocks seen a number of times. The oceurrenee of the species is reported from a point near the mouth of the Ohio, Villa Ridge, Pulaski Co., Ill., where. December 18, 1879, Prof. S. A. Forbes took a fine specimen; this is the most southern record in the Mississippi Valley. In Nebraska it has repeatedly been taken in different parts of the state between November 15 and March 1; also in Kansas and Illinois, where a large flock was once found feeding on Juniper berries, March 16, 1876.

*619. Aupelis cedrorum (Vieill.). Cedar Waxwing.

Ampelis americana. Bombycilla americana. Bombycilla carolinensis. Cedarbird. Cherrybird.

Geog. Dist.-North America, north to Prince Edward Island, Hudson Bay, Manitoba, Saskatchewan and British Columbia; breeding from Virginia, North Carolina, Kentucky, Missouri, Kansas, New Mexico and Arizona northward and wintering in whole of United States, south to Bahamas and through Mexico to Costa Rica.

As a summer resident in the sense of breeder, its usual meaning, the Cedarbird is apparently rare in Missouri, although common during a large part of our long summers. The species is with us 
in force when our early cherries are ripening until the middle of June, and as early as the middle of August, when the wild cherries and grapes are getting ripe, we meet them again in flocks, but this time with fully grown young, known by their streaked underparts. It is probable that all the young ones which we see in August are bred in the state, but there is no bird more secretive than the Cedarbird in breeding time. We never hear it, because it has nothing to say, being always alone, and, when we happen to see one, which is seldom, it seems in great haste to go to a place far away. It may nest in our own garden or orchard and we will not be the wiser until perchance one of the youngsters comes to our door, or, what has actually happened to the writer, into the house itself, before it can fly. That it used to nest in the city of St. Louis is attested by Mr. Philo W. Smith, Jr., who found nests in Tower Grove Park in 1900 and in North St. Louis in 1891. Mr. C. W. Prier found a nest, July 16, 1903, in an orchard in Appleton City, and the species is given as a breeder in Lawrence Co., by Mr. H. Nchrling; in Warrensburg by Mr. A. F. Smithson; in Keokuk by Mr. E. S. Currier. Orchards, cemeteries, city parks, and the shade trees in the immediate surroundings of houses in the country, seem to be the places where we have to look for their nests from the middle of June to the end of July. Though we may meet with flocks of Cedarbirds in any month of the year, there are certain times when we can count on seeing them with us regularly and in numbers. This is the time of the mulberries and first cherries in May, and of the abundance of wild fruit of many kinds, wild cherries, grapes, hackberries, smilax, etc., from the latter part of August to the middle of October. During the day they roam in search of food in troops of thirty or more and in the evening assemble in large numbers at a common roost, preferable the willows in the river bottoms. They are great wanderers and, although withdrawing from the state during the coldest spells of winter, the first flocks are back again as soon as the weather moderates, be this in January, February or March.

Family LaniddaE. Shrikes.

621. Lanius borealis Vieill. Northern Shrike.

Lanius excubitor. Collyrio borealis. Collurio borealis. Butcherbird.

Geog. Dist.-Northern North America, breeding from Labrador and Saskatchewan north to Alaska. In winter south 
from the Maritime Provinces and Ontario to Virginia, Kentucky, Missouri, Kansas, New Mexico, Arizona and central California.

In Missouri a rather common winter resident from the latter part of October to early March. Earliest dates at Keokuk, October 25, 1900; October 27, 1896 and 1901; October 31, 1897 ; latest, March 7, 1896 and 1897, March 9, 1902, and March 17, 1901; April 9, 1899. Earliest at St. Louis, November 2, 1906; latest from St. Joseph, April 7, 1896. Mr. Chas. L. Eimbeck has three fine specimens in his collection taken near New Haven, Mo., but there are at present no records available from the state south of St. Louis and Franklin Counties.

*622e. Lanius ludovicianus migrans $\mathrm{H}$. Palmer. Migrant Shrike.

Collyrio excubitoroides. Collurio ludovicianus var. excubitoroides. Lanius ludovicianus. Northern Loggerhead Shrike.

Geog. Dist.-Greater part of the United States east of the Great Plains, but very local in more eastern districts; breeding north to New Brunswick, Maine, New Hampshire, Vermont, northern New York, Quebec, Ontario, Michigan, Wisconsin, Minnesota and southward to midland Virginia and western North Carolina, Kentucky, Missouri, and eastern Kansas; in winter from Missouri, etc., southward to Mississippi, Louisiana, Texas.

This new subspecies has lately been separated from typical ludovicianus, which oceurs only in the South Atlantic and Gulf States, while the range of the western subspecies, excubitorides, the White-rumped Shrike, does not reach our state, terminating in central Kansas and eastem Nebraska. In Missouri, a fairly common summer resident on cultivated land, chiefly in the prairie and Ozark border region, searce in the Ozarks and the southeast. In mild winters some remain at their breeding stands from the Missouri River southward, but the majority leave the state in October and do not return till the third week of March, when the first Shrikes are back at their stations in all parts of the state. Full numbers are present before the end of the month, when the old pairs have alrearly begun building their nests, the species being among the earliest breeders, having fully fledged young in the fourth week of May. They make very amusing pets, being remarkably bright and the males somewhat musical. 
Family Vireonidae. Tireos.

*624. Vireo olivaceus (Linn.). Red-eyed Vireo.

II uscicapa olivacea. Tireosylvia or T'ireosylva olivacea. "The Preacher."

Geog. Dist.-North America, chiefly eastern, west to Utah, Washington and British Columbia; north to Nova Scotia, Prince Edward Island, Kewatin, Saskatchewan and southern Mackenzie; breeds from southern Florida and western Texas northward throughout all wooded regions. In winter through Mexico, Central and South Anerica to Brazil, Bolivia and eastern Peru.

In Missouri the most evenly distributed woodland summer resident from April till October. It is equally at home in the overflowed region of the southeast as on the driest hilltops of the Ozarks and in the small wood-patch left on northern and western farm lands. It begins to sing soon after its arrival, which is in the southeast as early as April 10; at St. Louis and central Missouri generally between April 21 and 26, sometimes even earlicr as April 16, 1896, April 17, 1855; and along the northern border about the first of May. Its song is heard all spring and summer, even during the hottest hours, when most other birds are silent. After a silence of five or six weeks the song is taken up again before its departure and is heard as late as September 21, 1895, and September 24, 1887. The bulk of transients passes through early in May, and again about the middle of September. The species is searce after September 25, but October records are not rare, October 1, 1895, being the last for Keokuk and October 10, 1855, for St. Louis.

\section{Vireo philadelphicus (Cass.). Philadelphia Vireo.}

Yireosylva or Vireosylvia philadelphica. Brotherlylove Vireo.

Geog. Dist.-Eastern North America, north to Maine, New Brunswick, Ontario, Manitoba, Athabasca; breeds along the northern border of the United States, but chiefly north of it, and migrates over the whole of the United States east of the Plains (more sparingly east of Alleghanies) to Central America (no Mexican or West Inclian records).

With the exception of one, May 8, 1898, from Independence by $\mathrm{Mr}$. Chas. Tindall, there are no records of the occurrence of this species in western Missouri. In eastern Missouri it is a 
rather rare, but regular, transient visitant, especially frequent in the swampy southeast and along the shores of the Mississippi River from May 5 to 22. They seem sometimes to bo quite at home here and give their song freely. The return movement in fall extends over a period of from three to four weeks, from the second week of September to the first of October. Earliest, September 9, 1887; latest, October 4, 1895, in Dunklin Co. Mr. E. S. Woodruff's capture of a Philadelphia Vireo May 9, 1907, in Shannon Co., the heart of the Ozarks, proves that its transit through Missouri is not confined to the low land, where it has generally been observed, but takes place, as is the case with most other northern warblers, in a broad front, covering most, if not all, of the state. Two were taken by Mr. Woodruff, May 17, and one male, May 24, 1907, at Grandin, Carter Co.

\section{*627. Vireo gilvus (Vieill.). Warbling Vireo.}

Vireosylva or Vireosylvia gilva. Muscicapa gilva. Muscicapa melodia.

Geog. Dist.-Eastern North America, north to Nova Scotia, northern Ontario, Manitoba, west to North Dakota, southeastern Montana, Kansas, Oklahoma and Texas; breeding from Florida and Texas northward and wintering south of the United States, probably in Mexico. The typical species is replaced westward by the lately separated subspecies, $V$. gilvus swainsonii (Baird), which winters in Mexico.

In Missouri a fairly common summer resident of general distribution. Originally inhabiting the trees along rivers and lakes, it has now accommodated itself to the new conditions and likes to live in orchards, gardens and parks, even in the shade trees of big cities, where its song may be heard with a short pause in August during its entire stay from the middle of April till September 20. It is one of the earliest species of the genus Vireo to arrive in spring, the earliest being April 6, 1893, and April 8, 1890. This is the usual time for its appearance in the southeast: at St. Louis the majority of records are between April 16 and 20; in cool springs a few days later. By the end of April the bulk is present all over the state, also transients, and the species is one of the most musical in the great bird concert of that lovely scason. Fall migration takes place in September, September 15, 1895, being the last date at Keokuk, and September 27, 1891, for St. Louis. 
*628. Vireo flavifrons Vieill. Yellow-throated Vireo.

Muscicapa sylvicola. Lanivireo flavifrons.

Geog. Dist.-Eastern United States and southern Canada, north to Maine, Vermont, northern New York, southern Ontario and Manitoba; west to the edge of the Plains; breeds from northern Florida and southern Texas northward and winters from southern Florida and Cuba south through eastern Mexico and Central America to Colombia.

In Missouri a common and gencrally distributed summer resident in all wooded districts. It is the first of the Vircos to arrive in the state, having been heard as early as March 30, 1896, in the southeast. In the region of St. Louis it may be looked for between April 15 and 20 with much certainty; earliest date, April 13, 1887; latest, April 27. The retum morcment from more northern breeding grounds takes place in September, when it is for a while more conspicuous than ordinarily. Its song has been heard every day from September 1 to 9 , and at intervals throughout the month-September 28, 1895, September 29, 1905, October 1, 1887, October 2, 1906. Last individuals are noted as late as October 11, 1887, and October 12, 1895, at St. Louis, and October 17, 1903, at Monteer, Shamnon Co., by Mr. Savage, but the bulk of the species leaves us from about September 22 to 25 .

629. Vireo solitarius (Wils.). Blue-headed Vireo.

Muscicapa solitaria. Lanivireo solitarius. Solitary Vireo.

Geog. Dist.-Eastern North America; north to Prince Edward Island, Keewatin, Athabasca, southern Mackenzie; west to border of Plains; breeds from southern New England, Pennsylvania, Wisconsin and northern Dakota northward, and winters from the Gulf coast (Florida to Texas) southward to Cuba, eastern Mexico and Guatemala.

In Missouri a regular and fairly common transient visitant, passing through rather late in both seasons. Earliest date at St. Louis is April 21, 1896, and April 22, 1879, but the majority of dates of "firsts" are between April 29 and May 5. Their stay with us lasts about two weeks, May 10 to May 16 being the dates for birds last seen (May 17, 1907, St. Louis). These dates seem to hold good also for the western part of the state (May 15, 1899, Independence, Tindall; May 7, 1874, Warrensburg, Scott). In fall their presence extends over a period of at least four 
weeks from the midclle of September to the middle of October. Earliest date for the state is September 4, 1902, Jasper, Savage; for St. Louis, September 16, 1887; latest, Oetober 20, 1893. Their song is heard both in spring and fall, oftener in the latter, and mostly in October; earliest song, September 24, 1896; latest, October 20, 1893.

*631. Vireo noveboracensis (Gmel.). White-eyed Vireo.

Muscicapa noveboracensis. Muscicapa cantatrix.

Geog. Dist.--Eastern United States; north to Massachusetts, New York (occasionaliy further north), to the Great Lakes, southern Wisconsin, southern Minnesota; west to castern Nebraska, Kansas, Oklahoma and Texas (except Rio Grandle Yalley): breeding from northern Florida and Texas northward, and wintering from the South Atlantic and Gulf States southward through eastern Mexico to Guatemala.

In Missouri a common and generally distributed stmmer resident, rarer westward and most abundant in bottom land and along water courses throughont the rifferent regions. In the southeast the first White-eyes returi to their breeding grounds in the first week of April (April 2, 1896). In the vicinity of St. Louis the earliest clate is April 11, 1896, but commonly the dates of "firsts" fall between April 14 and 18, exceptionally as late as April 24, and the bulk is always back in the last clays of April in the western as well as the eastern part of central Missouri (Independence, April 29, 1900; April 30, 1899, Tindall). At the northern border Mr. Currier's dates at Keokuk vary between May 3, 1896, and May 12, 1898. The return movement southward takes place in the middle of September, when a decrease is noticeable after the species has been quite conspicuous as a songster during the first half of September. A few keep up singing and are occasionally heard till the end of the month (September 28, 1895, September 29, 1887). The last were noticed as late as October 14, 1885, but they are always scarce after September 26 to September 29 , even in southern Missouri.

*633. Tireo belln Aud. Bell's Vireo. Vireo belli.

Geog. Dist.-Prairie listricts of the Mississippi Valley, breeding from Tamaulipas through eastern Texas northward through 
Missouri and Kansas to northwestern Indiana, northern Illinois, southern Minnesota and South Dakota. Winters in Mexico.

In Missouri a fairly common summer resident in all prairie districts and the Ozark border east to St. Louis and northward, abundant at Keokuk (E. S. Currier). This is the last of the Vireos to arrive in spring. At St. Louis, and in central Missouri generally, the first may be expected between April 27 and 29, sometimes a day or two earlier, as April 26, 1882, and April 25, 1883. At Independence it was noted by Mr. Tindall April 27, 1900, and April 30, 1899. At Warrensburg May 5, 1874, by W. E. D. Scott. Audubon met with Bell's Vireo May 6, 1843, in the region of St. Joseph. Its arrival is reported May 4, 1902, at Jasper by Mr. Savage, and May 5, 1885 and 1886, at Mt. Carmel by Mrs. Musick. Mr. Currier's dates vary between April 30, 1895, and May 9, 1899, at Keokuk. The bulk of the species does not come to St. Louis before the first week of May and a week later to Keokuk. It sings almost as long as it is with us, even through August. Last day of its song and presence at St. Louis is September 22, 1905, and this seems to be the time of departure from its breeding grounds generally. Last at St. Joseph, September 19, 1894, S. S. Wilson; at Jasper, September 16, 1901, and September 20, 1902; at Monteer, Shannon Co., September 5, 1903, IV. G. Savage.

Family MNotimida. Wood Warblers.

*636. Mniotilta varia (Limn.). Black and White Warbler.

Certhia varia. Sylvia varia. Certhia maculata. Sylvicola varia. Mniotilta borealis. Mniotilta varia borealis. Black and White Creeping Warbler.

Geog. Dist.-Eastern North America, north to the upper Mackenzie Valley, Hudlson Bay, Anticosti and Newfoundland; west to Alberta, central Nebraska, eastern Texas. Breeds from Virginia, Tennessee, Louisiana and Texas northward, and winters from the Gulf States southward throughout the West Indies, Mexico, Central America to Colombia and Venezuela.

In Missouri a common transient visitant and a fairly common summer resident in all wooded regions, both in low and high localities, on the islands in the swamps of the southeast, as well as throughout the valleys of the Ozarks and in the timber of the Ozark border and prairie region. This is one of the first 
warblers to enter Missouri in the southeast. Its wiry notes were heard in Dunklin Co. as early as March 10, 1894. On March 24, 1896, they.were common songsters in Butler Co., but the neighborhood of St. Louis is not reached before the second or third week of April, carliest April 7, 1882 (Earliest for Vernon Co., April 9, 1894; for Keokuk, April 26, 1902; for Shannon Co., April 10, 1904; for Mt. Carmel, April 18, 1885; for Warrensburg, April 13, 1874). During the latter part of April and first half of May, transients are present in all parts of the state. Audubon met with the species at Fort Leavenworth May 4, 1843, and Dr. J. A. Allen at the same place about the same time in 1871. It is reported from St. Joseph May 4, 1895, by Mr. S. S. Wilson. Fall migration takes place all through September, and the species is most common between the 10th and 20th; the last seen at St. Louis September 29, 1887 and 1905, but in Dunklin Co. some were present during the first week of October, 1895.

*637. Protonotaria citrea (Bodd.). Prothonotary Warbler.

Motacilla citrea. Sylvia protonotarius. Vermivora protonotarius. Helinaia protonotarius. Dacnis protonotaria. Sylvicola auricollis. Golden Swamp Warbler.

Geog. Dist.-Eastern United States, north to Virginia, southern Ohio, Indiana, southern Michigan, northeastern Illinois, southern Wisconsin, southeastern Minnesota, eastern Nebraska. Breeds from northern Florida and the Gulf coast to eastern Texas northward, and winters in Cuba, and through eastern Mexico and Central Anerica to Colombia, Venezuela and Trinidad.

In Missouri a common summer resident in the large river valleys, chiefly that of the Mississippi, most abundant in the swamps of the southeast, less common in the valleys of the Ozarks, but occurring in every one, as well as in the western and northerm prairie region (Reported common at Warrensburg, Independence, and Vernon Co.). It is one of the first warblers to arrive in spring, its entrance into the peninsula being welcomed as early as the last day of March (1896). A few days later the fomales join them and pairs are seen entering holes in the second week of April. To the central part of the state they do not come before the third or fourth week of April, and to the northerm border about the first of May. The species withdraws from Missouri pretty early in fall. The last date for St. Louis is Septem- 
ber 9, but there is a record from New Haven, September 24, 1903. At the end of the month none were found in the peninsula.

*638. Helinala swainsonil Aud. Swainson's Warbler.

Sylvia swainsonii. Helonaea swainsoni. Helmilherus swainsoni.

Geog. Dist.-Southeastern United States, north to Virginia, southwestern Indiana, southwestern Missouri and west to Texas. In winter to Cuba, Jamaica and Central America to Panama.

In Missouri thus far only found as a summer resident on the so-called islands in the St. Francis basin in Dunklin Co., but research will probably reveal its cceurence as a not rare summer resiclent throughout the swampy portions of the southeast, particularly in the section east of Little River, where large canebrakes occur along our southern statc line. Vol 12 of the Auk for 1895 contains an announcement of its discovery in the state under the title: "Swainson's Wirbler an Inhabitant of the Swampy Woods of Southeastern Missouri," by O. Widmann (pages 112-117).

*639. Helmitherus verimorus (Gmel.). Worm-eating Warbler.

Sylvia vermivora. Dacnis vermivora. Heinaia vermivora. Helmintherus vermivorus. IIelminthotherus vermivorus. Termivora pennsylvanica.

Worn-eating Swamp Warbler.

Geog. Dist.-Eastern United States, north to southern Connecticut, southeastern New York, Pennsylvania, southern Wisconsin, southeastern Nebraska; breeds throughout its United States range and winters in the Bahamas, Cuba, Jamaica, Mexico, Yucatan, Guatemala, Honduras, Costa Rica and Panama.

In Missouri a fairly common, and, with the exception of the swampy southeast, a gencrally distributed summer resident, rarer north and westward, most common in the bluff regions of the southern part of the state, being partial to wooded hilly ground near ruming water. Mr. Nehrling considered it a rare breeder in Lawrence Co.; Mr. Scott found it rare at Warrensburg in 1874; Mr. Currier also calls it rare at Keokuk. Mr. Parker found it breeding in Montgomery Co., and we have reports of its occurrence at Boonville by Dr. Hoy, April 22, 1854; at Mit. Carmel by Mrs. Musick, May 20, 1885; at Iberia, Miller Co., April 28, 1902. Mr. B. T. Gault found it to be a common 
breeder in Reynolds Co, in 1892, and Mr. E. S. Woodruff found it common in Shannon Co., and mot with it in Carter Co., May 30,1907 . It begins to arrive on its breeding ground April 20, and full numbers are present the first of May. It leaves us early in September, the latest record for St. Louis, September 20, 1890.

*640. Melminthophila BaChmanil Aurl. Bachman's Warbler.

Sylvia bachmani. Helinaia bachmanii. Helminthophaga bachmani.

Geog. Dist.-Southem United States; on the Atlantic coast to Virginia; in the Mississippi Valley to southeastern Missouri, Kentucky, northeastern Arkansas; formerly to southern Indiana. To Bahamas in migration. Winters in Cuba.

In Missouri found to be a fairly common summer resident on the islands in the St. Francis basin, where nests with eggs were found on Culp Island, May 17, 1897, and May 1-t, 1898. The oceurrence of the species in Missouri was discovered May 7 , 1896, and reported in Auk, vol. 13, p. 264. The discovery of the first nest ever found was destribed in an article titled: "The Summer Home of the Bachman's Warbler no longer unknown," by O. Widmann, Auk, vol. 14, 1897, pages 305-310. Nest and eggs (3) were presented to the Bendire Collection of Eggs in the National Museum at Washington. The fincling of a second nest with three eggs on the same island was announced in Osprey, vol. 3, page 13; it is in the Parker Norris collection at Philadelphia. The species arrives on its breeding grounds about the middle of April: males in full song were present April 17, 1898, in Dunklin Co. The range in Missouri has been extended since the above was written by Mr. E. Seymour Woodruff's capture of a male on May 2, 1907, near Ink, Shamnon Co., in some low bushes in the dry bed (its normal state) of Spring Valley and again by his finding a Bachman's Warbler near Grandin, Carter Co., May 23, 1907. Of this he kindly wrote me the following: "This time it was in what I consider a more suitable location-a dense tangle near the bank of a stream. I heard a song which I recognized at once as a Bachman's though I only had heard it that once up in Shannon Co. It took me some little time before I could lay my eyes on him, for he was fearfully shy and moved about rapidly. I did not attempt to seeure him to confirm identification until I had spent over two hours there in hopes that I might find the nest, but 
finally shot him for fear I might not find him on a second visit. I am positive I heard another male at the same time."

*641. Helminthophila pinus (Linn.). Blue-winged Warbler. Certhia pinus. Helminthophaga pinus. Sylvia solitaria. Vermivora solitaria. Helinaia solitaria. Blue-winged Yellow Warbler.

Geog. Dist.--Eastern United States, north to southern Connecticut, southeastern New York, Pennsylvania, northern Ohio, northern Indiana and Illinois, southern Wisconsin, eastern Nebraska. In winter through eastern Mexico to Guatemala, Nicaragua and Colombia.

In Missouri a fairly common summer resident of general distribution, but like other ground-builders disappearing from districts where the only remaining woodland is used as pasture for hogs, which either drive the birds from their breeding grounds or destroy the eggs or young in the nest. Audubon met with the species at Fort Leavenworth, May 4, 1843, and Dr. J. A. Allen at the same locality in May, 1874; Dr. Hoy found it at Boonville, April 22, 1854, and common at Chillicothe, May 16, 1854. It is an inhabitant of the valleys of the Ozarks and of the drier parts of the southeast, but the bluff region of the rivers and the Ozark border region seem to be territory most frequented. The species is the earliest of the genus to come to us in spring, appearing at our southern boundary, April 3, 1896; at St. Louis and central Missouri generally, April 20; earliest at St. Louis, April 17, 1883; at our northern border, April 30 to May 5, when the bulk has reached the rest of the state. It leaves us carly in fall; the last seen at St. Louis is September 6 to September 10, (1901).

641.1. Helminthophila leucobronchialis (Brewster). Brewster's Warbler.

Helminthophaga leucobronchialis.

Geog. Dist.-Southern New England, New York, New Jersey, Pennsylvania, Maryland, Virginia, Louisiana, Michigan.

For the introduction of this interesting bird into our list I am indebted to Mr. Edward Seymour Woodruff, who has furnished among the many valuable notes made during his two months sojourn in Shannon Co., in the spring of 1907, the Brewster's Warbler, a record new to the state. In a letter dated May 18, 1907, he writes: "It is an absolutely typical specimen, 
for there is not even a suggestion of a yellow tinge on the breast -pure white from bill to tail, and wingbands broadly yellow. I secured him on May 12; was attracted to it by its song, which, though similar in character to that of the Blue-wing, was weaker and varied-most noticeably different."

642. Helminthophila chrysoptera (Linn.). Golden-winged Warbler.

Motacilla chrysoptera. Sylvia chrysoptera. Vermivora chrysoptera. Helinaia chrysoptera. Helminthophaga chrysoptera.

Geog. Dist.-Eastern United States, north to Massachusetts, southwestern Ontario, northern Michigan, central Wisconsin, southern Minnesota; breeding from South Carolina in the mountains, and from northern New Jersey, northern Indiana, Illinois, eastern Nebraska northward and wintering in the mountains of Central and South America from Nicaragua to Colombia.

In Missouri a fairly common transient visitant in the vicinity of St. Louis, the bluffs of the Mississippi being the only locality where the species has been found of regular occurrence in the state. Mr. E. S. Currier considers the Golden-winged Warbler a common transient at Keokuk and there is a record of its occurrence in Shannon Co., April 25, 1905, by Mr. IV. G. Savage. The only record from western Missouri is by Mr. H. Nehrling, who met with it in Lawrence Co., April 25, 1884. Mrs. Musick reported the species as a summer resident at Mt. Carmel, Audrain Co., in 1884, and it is very likely that it breeds sparingly in northeastern Missouri. Mr. Currier took a set of eggs in Lee Co., Ia., just across the state line, and Mr. O. C. Poling of Quincy found it nesting in the Mississippi bottom. In eastern Illinois it was once found breeding in the latitude of St. Louis, $38^{\circ} 38^{\prime}$, in Richland Co. Singing males have been noted at St. Louis as early as April 26, 27 and 28, but the bulk passes through during the first half of May; last seen, May 22. At Keokuk they were observed once as early as April 22, 1894. They begin to withdraw from the breeding grounds early in August and pass through Missouri in the latter part of August and early in September, but do not stop over long and are therefore easily overlooked. Latest date at St. Louis, September 15, 1905; males in full plumage. 
645. Helminthophila rubricapilla (Wils.). Nashville Warbler.

sylvia ruficapilla. IIelminthophaga ruficapilla. Helminthophila ruficapilla. Sylvia rubricapilla. Vermivora rubricapilla. Helinaia rubricapilla.

Geog. Dist.-Eastem North America, north to Cape Breton, Prince Edward Island, Quebec, Ontario and Manitoba; breeds from southern New England, northern Michigan, northern Illinois, eastem Nebraska, northward. Winters in eastern Mexico; south to Guatemala.

In eastem Missouri one of our most regular and common transient visitants, spring and fall; also common in the northwestern part of the state, but rare in southwest Missouri. The species is rare in Kansas, but common in the Missouri River region of eastern Nebraska. Dr. J. A. Allen found it common at Fort Leavenworth, where it had also been observed by Audubon, May 4, 1813. It is reported from St. Joseph, where Mr. S. S. Wilson took a female September 28, 1895, and from Independence, October 5, 1889, by Mr. Chas. Tindall. Scott gives it as rare May 7, 1874, at Warrensburg, where Mr. Smithson found a young bird dead in the street in the middle of August, 1906. There is a possibility of its breeding in the northwest corner of Missouri as it has been found breeding along the eastern edge of Nebraska. East of Missouri its nesting in the latitude of our northern border is reported from Fulton Co., Ill., by Mr. Philo W. Smith Jr. of St. Louis. The first transients appeal in eastern Missouri between April 23 and 29, exceptionally earlier or later (April 20, 1885, May 2, 1883). They are most abundant during the first decade of May, the last being seen between May 15 and 22. On their return in the fall the first have been seen as early as September 5, 1897, but usually not before September 14 or 15 ; they are quite common from September 20 to October 5, and the last do not leave us before October 12, exceptionally as late as October 20, 1893.

646. Helminthophila celata (Say). Orange-crowned Warbler. Sylvia celata. Vermivora celata. Helinaia cclata. Helminthophaga celata.

Geog. Dist.--Eastern North America, north to the Mackenzie and Yukon Rivers; west in Canada to the interior of British Columbia and southward in the Rocky Mountains to New Mexico; breeding in the Rocky Mountains and from Manitoba 
northward; migrating over Mississippi Valley and Gulf States to South Carolina, Georgia and Floricla; rare east of Alleghanies north of Virginia. Winters in southern United States, but chiefly in northeastern Mexico.

In western Missouri a regular and common trunsient visitant. It is reported so by Dr. Allen, who met with it in May, 1871, at Fort Leavenworth; by $\mathrm{W}$. E. D. Scott who found it next to $H$. pinus, the most common of the genus, April 27 to May 15, 1874, at Warrensburg. Mr. Chas. W'. Tindell reports it as common at Independence, April 29, 1898, and April 30, 1899. Mr. H. Nehrling's record of April 19, 1854, is the earliest date for spring arrival in Missouri. The occurrence of the species in eastern Missouri is less regular both in time and numbers. Quite common in some seasons as early as April 20 and 22, in others it is not seen before the 28 or 29 . May 10 is the latest at St. Louis; in most years not seen after May 5. Its presence in fall extends orer a period of seven weeks from September 9 to October 26, but it is never numerous at any time. Neither Mr. Currier nor Mr. Praeger met with the species at Keokuk, but Mr. Chas. K. Worthen mentions it in his list of the birds of Warsaw, Ill.

647. Helminthophila peregrina (Wils.). Tennessee Warbler. Sylvia peregrina. Vermivora peregrina. Helinaia peregrina. Helminthophaga peregrina. Sylvicola missouriensis.

Geog. Dist.-Eastern North America, north to Hudson Bay, Slave Lake and Alaska; breeds from northern New York, northern New England, Quebec, Ontario, Manitoba, eastem Colorado northward and migrates chiefly through Mississippi Valley and Atlantic side of Mexico and Central America to northern South America.

In Missouri by far the commonest species of its genus and the most regular in migration; it outnumbers all other Helminthophilae put together and occurs in the west as well as in the east; in the southeast and the Ozarks as often as in the flood plains and the prairie region. At St. Louis it makes its first appearance between April 25 and 28, rarely a day earlier or later. It is in greatest abundance between April 30 and May 11, when it may be heard or seen most anywhere. After the middle of May it is scarce except in cold Mays, when it remains longer, as late as May 22 and 24, once even to May 29 and in 
the remarkable late spring of 1907 to June 3. Its fall migration reaches us the middle of September, becomes brisk about October 1 and continues to the middle of the month, latest date being October 20.

648.a. Compsothlypis americana usneae Brewster. Northern Parula Warbler.

Sylvia americana. Sylvicola americana. Parula americana. Blue Yellowback.

Geog. Dist.-Eastern United States and British Provinces; breeding from the interior districts of Virginia and Maryland northward to Maine, Anticosti, New Brunswick and northern Ontario.

*648.b. Compsothlypis americana ramalinae Ridgw.

Western Parula Warbler.

Geog. Dist.-Mississippi Valley, north to southern Michigan, across Wisconsin to Minnesota; west to eastern Nebraska and through Kansas, Indian Territory and Texas. These subspecies have lately been separated from the typical americana, which breeds locally in the Gulf States from Alabama to Florida and along the Atlantic slope to District of Columbia, probably to New Jersey and New York. Since the differences in the winter plumage are so slight that nobody can tell the three subspecies apart with certainty, their winter home can only be given for all of them together. They have a wide range throughout the West Indies, and through eastern Mexico to Nicaragua.

Our Missouri bird, which was until 1897 simply americana and then segregated as usneae, must now be referred to the new subspecies ramalinae, but it is possible that the northern subspecies usneae visits the state in transit from and to Mexico. Observers should be on the look-out for it during migration time. The Parula or Blue Yellow-back is one of the first warblers to appear at its breeding stations; it is a fairly common and generally distributed summer resident in the overflow of the peninsula as well as in the valleys of the Ozarks and along the water-courses everywhere, though less and less common as we go northwestward in the prairie region. It reaches Missouri in the southeast in the last week of March (Poplar Bluff, March 28, 1896). Earliest date for St. Louis is April 10, 1887, 
and April 11, 1896, but ordinarily it has not been noticed before April 13 to 17. About April 20 it is generally pretty numerous and the height of the season for transients is the first week of May. During its southward flight in September the species is again often seen and sometimes heard to sing, especially in the second and third week of the month. The last ones are seen in the vicinity of St. Louis, September 24 to 26, exceptionally later, October 2, 1906, and in Dunklin Co., October 4. Though a fairly common breeder in Missouri it is still much of a mystery where it places its nest. The only one found by the writer (Jume 8, 1885) was built inside of a bunch of rubbish which during a freshet in the Meramec River had kept sticking to a long hanging twig of a birch. This nest is described in Auk, vol. 2, p. 377; but such a place can only be an exceptional nesting-site, and it still remains to be shown where it usually builds its nest, as we have no hanging lichens used for this purpose in other parts of the country.

6.50. Dendroica tigrina (Gmel.). Cape May Warbler.

Motacilla tigrina. Dendroeca tigrina. Perisoglossa tigrina. Sylvia maritima. Sylvicola maritima.

Geog. Dist.-Eastern North America, north to the Maritime Provinces, southern shores of Hudson Bay, Manitoba and Assiniboia. Breeds from northern New England, northern Minnesota and Michigan northward and winters in the West Indies and Yucatan.

In Missouri a rather rare transient visitant in the vicinity of St. Louis, where its presence in small numbers can be expected early in May, oftenest May 2 or 3, latest May 10, 1887, and May 12, 1885 (May 16 and 17 to May 28, 1907) either among other warblers or in little troops by itself. In fall migration dates of occurrence are more scattered, beginning with August 24, 1887, and ending September 26, 1897. The only record for the state outside of St. Louis Co. is from Pierce City, Lawrence Co., where Mr. H. Nehrling found the species April 27, 1884. Since the above was written another record has been added through Mr. E. S. Woodruff's excellent work in Shannon Co., where he took examples of this species, May 10 and 15, 1907. 
*652. Dendroica aestriva (Gmel.). Yellow Warbler.

Motacilla aestiva. Sylvia aestiva. Sylvicola aesitva. Sylvia citrinella. Sylvia childrenii. Sylvia rathbonia. Sylvia trochilus. Wild Canary, Yellowbird. Blue-eyed Warbler.

Geog. Dist.-North America in general (except Alaska and northern Pacific coast where subspecies, rubiginosa, and southwestern United States where subspecies, sonorana). Breeds nearly throughout its range except Florida and southern Georgia. Winters in Central and South America going as far south as $7 \circ \mathrm{S}$. in western Peru.

In Missouri a fairly common summer resident in all settled districts, but not in the forest or far away from water; otherwise of general clistribution in all regions. The third week of April is the time for the arrival of the first Yellow Warblers in the vicinity of St. Louis; in more southern parts a few days earlier (April 13, 1893, at Hornersville), in the northern from five to ten days later, but on the whole there is a great regularity in their appearance. As with most other bircls the first comers are old males in full song, followed a few days later by their mates. Numerous transients are present during the last days of April and the first half of May when the species is one of the most conspicuous songster's about our country homes. Its song is heard until the midclle of July, when the species clisappears from the breeding ground, apparently retiring southward, but at the borler of lakes and rivers we sometimes meet a few transients during August, very rarely in September. Latest record, September 17, 1885, Mit. Carmel, Mrs. Musick.

654. Dendroica Caeruleschass (Gmel.). Black-throated Blue Warbler.

Sylvia canadensis. Sylvicola canadensis. Dendroeca canadensis. Sylvia caerulescens. Sylvia pusilla. Sylvia leucoptera. Tireo sphagnosa.

Geog. Dist.-Eastern North America, breeding from northeastern Connecticut, mountains of Pennsylvania, northern Ontario, southern Michigan, and Minnesota northward to Newfoundland, Labrador and shores of Hudson Bay. During migration westward to base of Rocky Mountains in Colorado and New Mexico. Winters in the West Indies and northern South America.

In Missouri a rare transient visitant, less so in the east than in the west, where records are very few. Dr. Hoy mentions it in 
his list of birds of westem Missouri and Mr. H. Nelırling found it at Pierce City, May 2, 188t. There is a single record from Iberia, Miller Co., but no other observer in Nissouri reported it to the Department of Agriculture, and neither Mr. Currier nor Mr. Praeger met with it ncar Kieokuk, nor has it ever been observed in the southeast. The only location where it has been found of tener is the immediate vicinity of St. Louis, and there, too, its occurrence is irregular. The earilest date for the state is April 27, 1904, Iberia, and for St. Louis, April 30, 1885; the last in spring, May 9, 18s7. The earliest in fall, September 1, 1887, an adult male, and the last, September 24, 1879, also an adult male.

65j. Dendrolca coronata (Limn.). Nyrtle Marbler.

Sylvia coronata. Syluico'a coronata. Yellow-rumped Warbler. Yellowrump.

Geog. Dist.-Eastern North America, north to limit of treegrowth from Newfoundland and sonthern Labrador to westem Alaska. Breeds from western Massachusetts and northern New York, northern peninsula of Michigan, Manitoba, Saskatehewan and Alberta northward. Winters from southern New England, Ohio and lower Missouri Valleys southward to West Inclies and through Nexico and Central America to Panama.

In Missouri a very common transient visitant in all parts of the state, and a fairly common wintor visitant in the heavily wookled southeast, less regularly northwarl to the Missouri River. Their presence in winter depends largely on the abundance of drupes of Poison Ivy, of which they are very fond and in search of which they roam about. If there is enough of this berry-like fruit, Yellow-rumps may be found in considerable numbers in St. Louis Co. throughout December, but their ranks are always thinned very much in January when our coldest weather comes, though a few sometimes brave the rigor of our hard winters successfully. They also like to eat the berries of the Red Cedar, and Dr. Eimbeck tells me that the Cedars in his place at New Haven, Franklin Co., are a great attraction for wintering Yellow-rumps. Being the hardiest of all Warblers and the earliest to push northward, small numbers appear in places where they have not wintered, even north of the Missouri River, as early as the second or third week in March, but real migration does not set in before the first of April and in backward springs as late as the 9 th and 12 th of that month. At 
our northern border where the first arrive about the 12th or 14th of April the species has in some years not been noted before the 25th $(1897,1901$, at Keokuk). The bulk, the great army, spreads over most of the state during the second and third week of April and remains to the end of the fourth week. The duration of their stay with us varies greatly; in some years they pass through rapidly, in others they remain conspicuously abundant for a longer time. In 1878 the last Yellow-rump was noted at St. Louis, April 29; in 1886, May 18; in 1907, May 21; but usually between May 6 and 12. The wave of southbound Yellow-rumps reaches the northern border of Missouri in the latter part of September, the earliest at Keokuk being September 11, 1894, and September 12, 1899, the bulk about October 1. St. Louis is seldom reached before October first, and then only by small numbers. Earliest at St. Louis, September 17, 1897, and September 23, 1896. The first cross the southern border line about October 10 . The bulk is somewhat irregular in its transit through the state, some year's, following the first within a few days, early in October, in others not before the second and third week of the month. In northern Missouri migration is over from the middle to the last of October (October 14, 1896; October 26, 1897); in central Missouri it continues to the first, sometimes the second week in November (Mt. Carmel, November 3, 1884: November 11, 1885). In the neighborhood of St. Louis where they may be regarded as irregular winter visitants, all are gone in some years before the middle of November (November 7, 1882; November 11, 1885). The exceptional occurrence of a singing male Yellow-rump in summer (June 21, 1897) in St. Louis Co. is reported by the writer in “"The Osprey," vol. 2, No. 3, page 40.

657. Dendroica maculosa (Gmel.). Magnolia Warbler.

Motacilla maculosa. Sylvia maculosa. Sylvicola maculosa. Sylvia magnolia. Black and Yellow Warbler.

Geog. Dist.-Eastern North America, north to Newfoundland, Anticosti, Magdalen Islands, southern shores of Hudson Bay Great Slave Lake and Mackenzie River; west to British Columbia and eastern base of Rocky Mountains. Breeds from Massachusetts, mountains of Pennsylvania, northern part of lower Michigan, northern Minnesota and northern Manitoba and Assiniboia northward. Winters from eastern Mexico to Panama. 
In Missouri one of the most common and the most regular of transient Warblers in the eastern part of the state, but becoming scarcer and scarcer as we go westward. Dr. Hoy mentions it in his list of birds of western Missouri. IV. E. D. Scott met with it once, May 18, 1874, at Warrensburg, and Mr. H. Nehrling, May 2, 1884, at Pierce City. These are all the records we have from western Missouri. Its appearance at St. Louis may be looked for with confidence between May 3 and May 5, very seldom earlier (May 1, 1904) and delays of a few days are equally rare. The bulk is present during the second week of May. After the 16th the species becomes scarce and disappears entirely if the weather is hot. In cool Mays it has been known to linger a week (May 22, 1885) and even two weeks longer (May 29, June 3, 1907). It is one of the most abundant migrants in the southeast, where it remains as late as in the central and northern parts. On its return in fall the first reaches St. Louis early in September (September 5, 1887, September 5,1897 ), but the bulk is present between September 17 and 27, and the last leave us soon afterward, deserting even the heavily wooded southeast by October 10 (Last for St. Louis, October $5,1906)$.

*658. Dendroica Cerulea Wilson. Cerulean Warbler.

Sylvia cerulea. Sylvicola coerulea or caerulea. Dendroeca caerulea or coerulea. Sylvia rara. Dendroica rara. Sylvia azurea. Blue Warbler.

Geog. Dist.-Eastern United States and southern Ontario; rare east of Allgehanies. Breeds from the mountains of Virginia and Tennessee, northern Alabama and Louisiana north to southern Michigan and Minnesota, west to eastern Nebraska, Kansas and the Indian Territory. Winters from Panama to Peru.

In Missouri a common summer resident in high trees of bottom land along water-courses in all parts of the state, but disappearing with the trees, not accepting the conditions imposed by civilization. It may be found in orchards and like places during migration, but for its nests it wants high trees near water, building far out on horizontal or drooping branches, much to the disgust of the egg collector. The species is especially numerous in the southeast, where it arrives as early as April 10, 1893. The magnificent forests in the flood plains of the Mississippi and Nissouri Rivers afford homes for a large number of these diligent songsters. Audubon met with them at the mouth of Grand River, April 30, 1843, and again at Leavenworth, May 4, 
1843. At the latter place the species was found common by Dr. J. A. Allen in May 1871, and Dr. Hoy includes it in his list of western Missouri birds. At St. Louis it is seldom found before the middle of April (April 12, 1887), but generally in the third week, i. e., between the 15th and the $22 \mathrm{nd}$. The bulk, including the females, has come before the end of the month. After the breeding season is over Blue Warblers become scarce, apparently leaving their breeding grounds, but in Dunklin Co. individuals have been found through September (September $28,1897)$, and an exceptionally late date is reported from New Haven, September 25, 1903, by Dr. Eimbeck.

*659. Dendroica Pensylvanica (Linn.). Chestnut-sided Warbler.

Sylvia pensylvanica. Sylvia icterocephala. Sylvicola icterocephala. Yellowcrowned Warbler.

Geog. Dist.-Eastern United States and southern Canada, north to Nova Scotia, northern Ontario and Manitoba; west to eastern Nebraska and eastern Kansas. Breeds from the Alleghany Mountains in South Carolina, from New Jersey, Pennsylvania, Ohio, central Illinois, southern Missouri and eastern Kansas northward and winters from Guatemala to Panama.

In Missouri a fairly common transient visitant, less common westward, where it was taken by Audubon, May 4, 1843, and by Dr. J. A. Allen, May 1871, near Fort Leavenworth. Dr. Hoy has it in his list, also Mr. Chas. W. Tindall of Independence. Mr. S. S. Wilson gives it as rare at St. Joseph, where he took a male, August 28, 1894. IV. E. D. Scott has it as rare at Warrensburg, where he first noted it May 7, 1874. Though usually fairly common in eastern Missouri it is somewhat irregular in arriving; in some years the first are seen in the last week of April (earliest April 23, 1885, and April 25, 1886, at Mt. Carmel; April 26, 27 and 29, St. Louis); in other years not before the second week in May (May 11, 1886), but most of the dates collected at St. Louis as well as in the state generally are in the first week of May. In favorable weather transients pass rapidly through and disappear soon after the middle of May, but in cool weather they have lingered through the third into the fourth week (May 23, 1882; May 24, 1883; June 3, 1907). In fall the species is one of the first migrants to return from farther north, having been met with as early as August 24, 1896, and 
August 28, 1901, but the early part of September is the regular time for its reappearance, the bulk passing through between the 15th and 26th. None have been observed after the first of October. Beside being a transient the Chestnut-sided Warbler has repeatedly been found breeding in eastern Missouri in places grown with hazel, blackberry and scrub-oak. Nests with eggs have been found by the writer and by Mr. Philo W. Smith, Jr., in the outskirts of St. Louis City and in St. Louis Co. Mr. B. T. Gault saw a pair June 19, 1892, near Munger in Iron Co. undoubtedly on their breeding grounds. Mrs. M. Musick reported the species as a common summer resident at Mt. Carmel in Audrain Co., and Mr. E. S. Currier found it breeding near Keokuk.

660. Dendroica castanea (Wils.). Bay-breasted Warbler.

Sylvia castanea. Sylvicola castanea. Sylvia autumnalis.

Geog. Dist.--Eastern North America, north to Newfoundland, Hudson Bay and Manitoba. Breeds from northern New England, New York, southern Ontario, northern Michigan northward. Winters in Panama and Colombia.

In eastern Missouri a not common but regular transient visitant in spring and fall, chiefly in the flood plain and the bluff region of the Mississippi River, but also in the southeast. and in the Ozarks as far west as Shannon Co. (Monteer, May 3, 1904, Savage) and Carter Co. (Grandin, May 16, and 17, 1907, Woodruff). The only record from western Missouri is that of Dr. P. R. Hoy in May 1854. Its presence in spring oceurs between May 3 and 23, chiefly between May 5 and 15 in the region of St. Louis (May 16 to June 2, 1907). Being mostly silent and keeping in the densely-leafed trees it is easily overlooked, a fact which, together with its rapid passage, makes the species appear rarer than it really is. In fall its occurrence has been noted from September 4 to October 5 (1905 and 1906). Even its song has been heard as late as September 26, 1897. They are generally in company with other warblers, but sometimes in family groups by themselves, the adults in full spring dress.

661. Dendroica striata (Forst.). Black-poll Warbler.

Sylvia striata. Sylvicola striata.

Geog. Dist.-Eastern and northern North America, north to Newfoundland, to the limit of tree growth in Labrador, the 
Hudson Bay region and northwest to Alaska. Breeds from northern New England and New York, northern Michigan and Manitoba northward, also near Manitou, Colo., and in Montana and probably Wyoming. Winters in northern South America, east to French Guiana and Para, west to Ecuador; south as far as Rio Negro in Brazil. Migrates by way of Bahamas and West Indies; no record from Mexico and Central America.

In Missouri one of the most regular and most numerous transient warblers in spring, less common in fall, when easily overlooked, because silent, plainly garbed and slow in its movements. St. Louis can expect to greet the first Black-poll April 29, and judging from reports from Kiansas City (April 28, 1904) and from Independence (April 27, 1900), the army of north-going Blackpolls begins to invarle the southern part of the state generally the last days of April. They become more numerous after the first of May and the bulk is present during the second, in northern Missouri, during the third week in May. They are much oftener heard than seen, uttering a peculiarly grating song, while creeping along branches in the highest trees. Their song is heard dluring the first half of May almost everywhere, wherever there are trees. By the middle of May the singing males have usually passed on and silent females only are met with. In cool weather the departure is delayed and Black-polls have been noted at St. Louis as late as May 29, 1882, and at Keokuk, June 2, 1901, but they are always rare after May 20, except in the cold spring of 1907 , when unusually abundant at St. Louis from May 10 to Jume 6. In fall their passage through Missouri takes place in September, chiefly the latter part, and during the first week of Oetober, when on some days they occur in regular flocks.

662. Dendroica Blackburniae (Gmel.). Blackburnian Warbler.

Sylvia blackburniae. Sylvicola blackburniae. Sylvia parus. Sylvicola parus.

Geog. Dist.-Eastern North America, north to Maine, Nova Scotia, southem shores of Hudson Bay, northern Ontario, Manitoba, west to edge of Great Plains. Breeds from southern Alleghanies, Connecticut, New York, Pennsylvania, Michigan, Wisconsin and northern Minnesota northward. Winters chiefly in South America from Colombia to Peru.

In Missouri generally a rather rare transient visitant, but found in all parts of the state, though more frequently eastward. 
It is reported from western Missouri by Dr. Hoy in 1854 and by Dr. J. A. Allen, who found it at Leavenworth, May 4, 1S71; Mr. H. Nehrling observed it at Pierce City in 1884 and 1885 and there is a record from Kiansas City. The first reach the southern part of Missouri in the last week of April (April 28, 1905, Monteer, Shannon Co.); southwestern and central Missouri, early in May (May 2, 1884, Pierce City: May 4, St. Louis). The second week of May is the time when it is most numerous in the neighborhood of St. Louis, where the last is seen about May 17, but there is one exceptionally late record of its presence in the state from Kansas City, May 30, 1904. In fall migration it is, like others of its tribe, oftenest found in the river bottoms and does not seem to be in such haste as in spring, the same individuals being observed at the same place several days in succession. The first appear as early as September 1 (1897) and the last was noted as late as October 2, 1896, and October 5, 1905, but they are to be found most certainly between September 8th and 26th. Mr. E. S. Woodruff found one in Shannon Co., May 13, and several in Carter Co., May 16 and 17, 1907. Migration of Warblers being abnormally late in conformity with the extraordinary lateness of spring in 1907, the first Blackburnian was seen at St. Louis, May 14 and the last, May 22.

*663a. Dendroica dominica albilora Ridg. Sycamore Warbler.

Sylvia pensilis. Sylvicola pensilis. Dendroica superciliosa. D. dominica.

Geog. Dist.-Mississippi Valley, north to northeastern Nebraska, southern Wisconsin, southern Michigan, Ohio, West Virginia; southward to Louisiana and eastern Texas. Breeding throughout this range, bounded on the east by the Alleghanies, comprising an area about 800 miles long by 600 miles wide, having its centre of distribution in the lower Ohio Valley. In winter to southern Mexico and Central America.

Nowhere really common, the Sycamore Warbler is fairly well distributed through a large portion of southern Missouri from St. Charles and Montgomery Counties southwestward to Newton and MeDonald Counties in the southwest corner of the state. It inhabits the high trees of river banks from the Mississippi River westward throughout the Ozark and Ozark border region; is most common in the cypress swamps of the southeast, but apparently absent from the prairie region. On the southern slope of the Ozarks it has been found inhabiting the pines on 
the hilltops as well as the sycamores in the bottoms. In the southeast its nests are built in cypress trees (Taxodium). Near the southern boundary its arrival has been noted as early as March 21, 1894, when males were already in full song near Hornersville. In Shannon Co., Mr. Woodruff heard it for the first time March 28, 1907. In the vicinity of St. Louis the appearance of the first singing males varies according to the weather from April 4 to 13, but by the 25th they are always in full numbers and conspicuous songsters. About the first of September they begin to wander about and old and young are met with in places not usually visited. Dates of "lasts" vary greatly from September 2, 1887, to October 11, 1885, the latest for St. Louis.

667. Dendroica virens (Gmel.). Black-throated Green Warbler.

Sylvia virens. Sylvicola virens.

Geog. Dist.-Eastern North America, north to Newfoundland, islands of Gulf of St. Lawrence, southern shores of Hudson Bay, southwestern Athabasca and northern Alberta; west to the Plains. Breeds from the higher mountains in South Carolina, southern New England, northern New York, Michigan, Wisconsin, Minnesota northward. Winters from Mexico to Panama.

In Missouri one of our commonest and most generally distributed transient visitants in spring and fall, less common in the north-western portion of the state and the prairie region generally. Dr. Hoy listed it among his birds of western Missouri and W. E. D. Scott found it May 7, 1874, at Warrensburg. Mr. H. Nehrling reports it from Pierce City, May 2, 1884, and Mr. IV. Savage from Jasper, May 1, 1903. In the southeastern corner of Missouri the writer found it as early as April 16, 1898, but at St. Louis the firsts are noted between April 26 and May 1. In Shannon Co. where Mr. Savage found it to be tolerably common, the first was seen at Monteer, April 24, 1904; at Keokuk, April 30, 1895, is the earliest date reported by Mr.Currier. At St. Louis the bulk is present from between May 5 to 13 and the last has left before May 20 (May 22, 1907). The last at Monteer is May 10, 1904, in Carter Co., May 17, 1907, and at Keokuk, May 24, 1895. W. E. D. Scott found it as late as the middle of June, 1874, suggesting the possibility of breeding. Fall migration begins in the latter part of August and lasts through September to the second week of October at St. Louis 
and the end of the third week in the southeast; the majority pass through between September 8 and October 6 .

\section{Dendroica Kirtlandi Baird. Kirtland's Warbler.}

\section{Sylvicola kirtlandi.}

Geog. Dist. - Eastern United States and Ontario from Florida north to Michigan and Minnesota; west to Missouri. Breeds in Michigan. Winters in Bahamas.

A male taken by the writer May 8, 1885, near the city limits of St. Louis is the only record of the occurrence of this rare bird in Missouri. It is now in the collection of mounted birds in Washington University of St. Louis. Its capture is reported in "The Auk," vol. 2, page 382.

\section{*671. Dendroica vigorsil (Aud.). Pine Warbler.}

Dendroica pinus. Sylvia pinus. Sylvia vigorsii. Sylvicola pinus. Pinecreeping Warbler.

Geog. Dist.-Eastern North America, north to Nova Scotia, New Brunswick, Ontario, Manitoba and Saskatchewan. Breeds in pine woods, both north and south, and is found in hard wood forests only in migration. Winters in the South Atlantic and Gulf States.

In Missouri a fairly common transient visitant in the eastern part of the state, but apparently unknown in western Missouri north of the Ozarks. In the pine region the species is a rare summer resident. On its breeding grounds it had already arrived when Mr. E. S. Woodruff reached Grandin, March 8, 1907, and Ink, Shannon Co., March 10, 1907. April 25 he secured a young unable to fly, but fed by its parents on the ground. North-bound transients pass through from the middle to the end of April. Earliest at St. Louis, April 11, 1896: latest at St. Louis and Keokuk, May 3, 1903. Though never very common it is most numerous from April 21 to 23, when its peculiarly whirring song is often heard. This same song is also given in fall, when it spends two to three months in transit through the state. At St. Louis a singing male has been met with as early as August 20, 1905; others August 26, 1896, and August 29, 1897. The species remains through September into October, even to the latter part of the month (October 24, 1879), but is oftenest noted from about October 3 to 5 . 
672. Dendroica Palmarum (Gmel.). Palm Warbler.

Sylvia palmarum. Sylvicola palmarum. Sylvicola petechia. Yellow Redpoll.

Geog. Dist.-Eastern North America, rare in Atlantic States where replaced by the subspecies, hypochrysea, the Yellow Palm Warbler. Breeds north of Manitoba and west of Hudson Bay to Great Slave Lake. Winters in southern Florida, Bahamas and the West Indies. Migrates southeast-northwest, chiefly through the Mississippi Valley, from Alleghanies to eastern Nebraska, rarely to Kansas.

In Missouri a common transient visitant eastward, less common westward, where reported by Dr. Hoy, Mr. Tindall of Independence and Mr. Savage of Jasper (May 15-18, 1902). It is one of the earlier of north-bound warblers and in exceptionally early springs has found its way to St. Louis as early as April 5, 1882. Ordinarily it reaches the same locality between April 13 and 18; the bulk is present during the latter part of April and the last disappear between May 5 and 15 . It reappears at St. Louis about the first of October, remaining nearly throughout the month (October 26, 1885). At Keokuk Mr. Currier found it as early as September 11, 1893; Mr. Savage at Monteer, Shannon Co., not before October 17, 1903.

\section{*673. Dendroica discolor (Vieill.). Prairie Warbler.}

Sylvia discolor. Sylvicola discolor. Sylvia minuta.

Geog. Dist.-Eastern United States, north to Massachusetts, southern Ontario, southern Michigan, southern Wisconsin; west to eastern Nebraska, eastern Kansas. Breeds from northern Bahamas and Florida and the Gulf States generally northward. Winters from central Florida and Bahamas nearly throughout the West Indies to near the coast of Yucatan.

In Missouri a common summer resident throughout the Ozarks and Ozark border region from St. Louis Co. west and southward to the southwest corner of the state (Neosho in Newton Co. and Noel in McDonald Co.). In spite of its name it is not known to occur in the prairie region nor does it breed in the swampy southeastern portion of the state. A more appropriate name would be the Hillside Warbler. Its home is not in the forest, not among high trees, but in those stretches of scrub-oak which are found wherever the ax or fire have removed the original forest-trees. It is a neighbor of the Cardinal, Yellow-breasted Chat, Indigo-bird and Field Sparrow. It arrives on its breeding grounds about the middle of April and becomes generally distributed during the fourth week of the month. It remains with 
us until the latter part of September. Latest record at St. Louis, September 23, 1890.

*674. Seiurus aurocapillus (Linn.). Oven-bird.

Turdus aurocapilla. Siurus aurocapillus. Golden-crowned Thrush. Teacher.

Geog. Dist.-Eastern North America, north to Newfoundland, Gulf of St. Lawrence, Hudson Bay, Alaska; west to Colorado, Montana and British Columbia. Breeds from Virginia, southern Missouri and Kansas northward. Winters from the Gulf coast and the Bahamas through the West Indies and Mexico to Central America.

In Missouri a common summer resident, more abundant during migration. It is found oftener in the rich woods of the Ozark border and the bluff region along rivers than on the dry hills of the Ozarks and is rare in the southeast. Like the Towhee, Blue-winged and Worm-eating Warblers, Black and White Creeper, and other ground builders, the Oven-bird has entirely disappeared from wood-patches used for pasturing hogs, and is therefore rare in large districts where it was common formerly. Its arrival in spring takes place about April 10 in southern Missouri, about April 14 in east-central, and a week later in western Missouri. April 12, 1887; 12, 1904; 13, 1888, are the first dates for St. Louis, where during the last week of April the woods are fairly ringing with its song. At this period the number of Oven-birds is increased by hosts of north-going individuals, and during the last few days of April or first of May, the first have reached our northern border (Keokuk, April 27 to May 2; Fort Leavenworth, May 4, 1843, Audubon). The return of transients is noticeable in September, making the species conspicuous for a considerable time, but particularly from the 14 to the 24, when it becomes scarcer and disappears entirely during the first week of October. After being silent for about six weeks its song is again heard in the last week of August and first of September when it ceases.

675. Seiurus noveboracensis (Gmel.). Water Thrush.

675a. Seiurus noveboracensis notabilis (Ridgw.). Grinnell's Water Thrush.

Siurus naevius. Seiurus naevius. Turdus noveboracensis. Turdus aquaticus. Small-billed Waterthrush.

Geog. Dist. of noveboracensis.-Eastern North America, north to Newfoundland, coast of Labrador and Hudson Bay; breed- 
ing from mountains of West Virginia, northern New England, Michigan, Wisconsin northward. The subspecies, notabilis, ranges throughout western North America from Indiana and Illinois (more rarely eastward) to the Pacific, north into British Columbia and along the Rocky Mountains to Alaska and East Cape in Siberia. It breeds from Minnesota, western Nebraska and the more northern Rocky Mountains of the United States northward. In winter both subspecies go to the West Indies (chiefly the eastern form), Mexico, Central America, Panama, Colombia, Venezuela and British Guiana (both forms together). Water thrushes which winter in southern Florida are said to belong to the western subspecies, but there is so much difficulty in separating the two forms, that it has not yet been possible to trace their migration routes from summer to winter homes.

Eastern Missouri seems to be the region where these migration routes overlap, as we see birds both with white and decidedly yellow underparts. It will therefore be well for collectors to pay special attention to distinguish between the two forms in order to find out in what proportion they occur; it is generally accepted that the Water Thrushes of Missouri belong to the western form, notabilis. Water Thrushes are common and regular transient visitants in all parts of Missouri, but most common eastward, less so westward, where Audubon found them May 4, 1843, at Leavenworth and May 7, 1843, at St. Joseph. It is also reported by Mr. Tindall from Independence, May 15, 1899, and by W. E. D. Scott from Warrensburg, where it was quite common and first noted during the first week in May, 1874. In Taney Co. the writer found it common and in song along White River, May 7 to 10,1906 . Mr. E. S. Woodruff found it common in Shannon Co., May 9, 1907. In the vicinity of St. Louis the "firsts" appear with great regularity between April 24 and 28, exceptionally a few days earlier (April 21, 1883). The bulk is present from May 5 to 12 and the last are seen in the third week of May from the 15 to the 22, exceptionally later (May 31, 1897). There is very little difference between St. Louis dates and those collected by Mr. Currier at Keokuk, where it is an abundant migrant, arriving between April 20, 1896, and May 6, 1892, but mostly about April 30, with the last dates, May 11, 1897, and May 12, 1893. Its frequent song greatly facilitates identification, since it is entirely different from that of the Louisiana Water Thrush, in the haunts of which it often dwells while with us in spring migration, and with which it 
shares a characteristic alarm-note. It is the first warbler to return to us in fall, having been observed as early as August 12, 1887, on the sandy islands in the Mississippi River opposite St. Louis, but it is more common and generally distributed from the end of August to the fourth week in September, when most are gone, but, exceptionally, stragglers have been noted as late as October 17, 1885. In the abnormally cold spring of 1907 the species was not noticed at St. Louis before May 9, but it was unusually abundant and full of song from May 16 to 22.

*676. Seiurus motacilla (Vieill.). Louisiana Water-Thrush.

Turdus ludovicianus. Siurus motacilla. Seiurus ludovicianus. Largebilled Waterthrush.

Geog. Dist.-Eastern United States and southern Ontario, north to southern New England, southern Michigan, southern Wisconsin and southeastern Minnesota; west to eastern Nebraska, eastern Kansas, Texas. Breeds from the Gulf States northward and winters from the Bahamas through the IVest Indies to western Mexico and south through Central America to Colombia.

In Missouri a common and generally distributed summer resident, nore common south of the Missouri River than north of it except along the river bottoms. Near the state line in the southeast, where it is very common, it appears at its breeding stands about the middle of March (March 12, 1894), but near St. Louis seldom before April (earliest March 29, 1884), usually between April 4 and 12. Other early dates are Jasper, April 1, 1902; Warrensburg, April 1, 1905. Earliest at Keokuk, April 13, 1893. In Shannon Co. Mr. E. S. Woodruff noticed it first March 21, 1907. In fall it retires from its more northern stations in the latter part of September (last at Keokuk, September 14, 1893; St. Charles Co., September 27, 1905; St. Louis, September 29, 1885, and October 5, 1906). In Dunklin Co. it was still common and in song early in October, 1896.

*677. Geothlypis formosa (Wils.). Kentucky Warbler.

Sylvia formosa. Sylvicola formosa. Myiodioctes formosus. Trichas formosa. Sylvania formosa. Oporornis formosus.

Geog. Dist.-Eastern United States, north to southeastern New York (rarely to Connecticut and Long Island), New Jersey, eastern Pennsylvania, Ohio, southern Michigan, Wisconsin 
and Minnesota; west to eastern Nebraska and eastern Texas. Breeds from North Carolina, Alabama, Louisiana and Texas northward and winters from southern Mexico through Central America to Panama, rarely to Colombia.

In Missouri a common and generally distributed summer resident in all wooded districts, especially in river bottoms, in the southeast as well as in the Ozarks and prairie region. Audubon found it in the region of Leavenworth and St. Joseph, May 4 and 6,1843 . Dr. Hoy writes that it was abundant in the Grand River bottom near Chillicothe, May 16, 1854. Dr. J. A. Allen noted it at Leavenworth in May 1871, and W. E. D. Scott calls it a common, but shy breeder at Warrensburg in 1874. In the peninsula, where summer sojourners arrive much earlier than in the rest of the state, its presence has been noted as early as April 9, but in the vicinity of St. Louis the "firsts" are recorded between April 21 and 25, and in western and northern Missouri in the last days of the month (St. Louis April 21, 1885, April 21, 1886; Independence April 29, 1900, April 30, 1899; Stotesbury, Vernon Co., April 30, 1898; Keokuk, April 26, 1898, April 30, 1895). Full numbers have seldom been present at St. Louis before the first week of May. The bulk of the species leaves us in August and the last bird was seen at St. Louis September 8, 1897.

678. Geothlypis Agilis (Wils.). Connecticut Warbler.

Sylvia agilis. Sylvicola agilis. Trichas agilis. Oporornis agilis.

Geog. Dist.-Eastern North America, north to New England, Ontario, Michigan and Manitoba. Breeds in Manitoba, Minnesota, Wisconsin and northern Michigan. Winters somewhere in South America, migrating by way of Bahama, but never recorded from October 22 to April 9.

In Missouri a rather rare but regular spring transient visitant along the eastern border from St. Louis northward (Quincy, Warsaw, Keokuk). Only one record in fall, October 5, 1897, Keokuk, Mr. E. S. Currier. The 14th, 15th and 16th of May are the days when it is first noted at St. Louis and it is always with us on May 20th, 21st and 22nd, and likely to remain to the end of the month, if the weather is cool. May 29, 1882, May 31, 1897; and at Keokuk, June 1, 1897. It frequents dark, shady forests and is usually seen along the banks of creeks and sloughs. Very shy, it would easily escape detection, if its very 
peculiar song would not betray it. This song is oftenest given in the forenoon after most other songsters have already quieted down and, although it raries considerably in different individuals, it can always be rendered by a three-syllabled word with the accent on the first syllable, repeated three times, and followed by a one-syllabled "hee" in a higher key.

679. Geothlypis Philadelphia (Wils.). Mourning Tarbler.

Sylvia philadelphia. Trichas philadelphica.

Geog. Dist.-Eastern North America, north to Nova Scotia, New Brunswick, Prince Edward Island, central Ontario and Manitoba and eastern Assiniboia. Breeds from the mountains of West Tirginia, from New England, New York, Michigan, Minnesota, Nebraska and North Dakota northward. Nigrates by way of Louisiana and Texas to Nicaragua, Costa Rica, Colombia and Ecuador. No records in the South Atlantic and Gulf States from North Carolina to Mississippi.

In Missouri a fairly common transient visitant in all parts of the state, rarer westward, where found by Audubon near St. Joseph, May 6, 1843. Writing his diary at Chillicothe, May 16, 1854, Dr. P. R. Hoy says: "Here we found the home of Trichas philadelphia, a locality where this bird is common; they frequent localities covered with dense underbrush overrun with climbing roses and honeysuckles. I listened to the song of $T$. philadelphia, $T$. marylandica and $T$. formosa at the same time." In his list of birds made at Narrensburg, Johnson Co., IV. E. D. Scott says of this species: "Not very rare; took two during the spring; the first May 12, the second May 18, 1874." Though the first may be found in the second week of May (May 10,1886 , St. Louis) we are most sure to find it during the third week or from 14th to 21st and in cool weather even later, the last at St. Louis being May 26, 1882 and 1886. At Keokuk, where they are usually found in the fourth week of May, they linger into June, and Mr. E. S. Currier reported one as late as June 25, 1893, possibly a summer resident. In fall the species passes through in September (September 10, 1901), but is easily overlooked, because very shy and silent. Mr. E. S. WToodruff took one at Eudy in Shannon Co., May 13, 1907. At St. Louis the first was seen May 18, 1907, and the last, a pair with the the male in full song, remained at the same place from May 30 to June 3 . 
*681d. Geothlypis trichas bRachidactyla (Swains.). Northern Yellow-throat.

Sylvia trichas. Trichas marylandica. Trichas personatus. Maryland Yellow-throat.

Geog. Dist.-Northeastern United States and southeastern British Provinces, from Newfoundland, southern Labrador, Quebec, Nova Scotia, New Brunswick, New England, New York and northern New Jersey westward to northern Ontario, Michigan, Wisconsin, Minnesota, eastern Dakota, Athabasca and Alberta; southward through the Mississippi Valley to upland of Gulf States and eastern central Texas. In winter to Bahamas, Cuba, Jamaica, Swan Island and through eastern Mexico to Costa Rica; during migration whole United States east of the Great Plains. Yellow-throats which winter in southem Louisiana and Texas are said to belong to the subspecies ignota and trichas. The Yellow-throats of eastern North America are at present (1907) split into three subspecies, of which the northern has the largest range; ignota is the southeastern form, from Virginia along the edge of the coastal plain to southern Georgia and Florida, thence westward to Louisiana. The typical trichas trichas has the smallest range between the two others on the Atlantic coast from Georgia to Maryland and southern New Jersey.

The Yellow-throat is one of the commonest, probably the most common, of summer resident warblers in Missouri; it inhabits forest and swamp as well as cultivated land and is found in the Ozarks and prairie region, in the bottoms as well as on the bluffs of our rivers throughout the state. Like many other summer sojourners it begins to return to its breeding grounds in the peninsula of the southeast much earlier than to the rest of the state and was found in Pemiscot Co. as early as April 8, 1893. The earliest at St. Louis is April 14, 1887, but as the weather at that time is often adverse to bird migration, the majority of records of first arrivals is between April 17 and 21 , in some years even a few days later. April 27 is the day when it is numerous and noisy, indicating the arrival of the bulk, including females; and large numbers of transients remain with us during the first week of May, when the species is met with everywhere, even in gardens, orchards and places where it does not nest. In northern and western Missouri it is usually a few days later than at St. Louis, being noted first during the fourth week of April and at the northern border at Keokuk 
often only in the last two days of the month or in May. Fall migration begins early in September, when its song is again heard; adults and young are abundant during the second and third week at St. Louis and their song is heard as late as September 19, but the species grows rapidly scarce after the 20th and only plain-colored, shy loiterers are met with at the end of the month or in early October. Last records at St. Louis are October 2, 1887, October 4, 1895, and October 1, 1896; latest for the state is October 14, 1903, New Haven, Dr. Eimbeck.

*683. Icteria virens (Linn.). Yellow-breasted Chat.

Icteria viridis. Pipra polyglotta.

Geog. Dist.-Eastern United States and southern Ontario; north to New England, southern Michigan, southern Wisconsin and southern Minnesota; west to eastern South Dakota, eastern Nebraska, Kansas, eastern Texas and southward to the Rio Grande where meeting the western form longicauda. Breeds from Rio Grande and upper portions of Gulf States northward, and winters southward through eastern Mexico and Central America to Costa Rica. It does not visit Florida, Bahamas and West Indies.

In Missouri the Chat is a common summer resident in all parts of the state, but particularly abundant in the Ozark and Ozark border regions. In its return to the breeding grounds it is pretty regular, appearing at St. Louis and in most parts of southern Missouri between April 23 and 28. Exceptionally early dates have been recorded, as St. Louis, April 18, and Kansas City, April 20, 1903; Keokuk, April 19, 1896. This latter date is extremely early as the "firsts" of eight other years vary between April 29 and May 6 (E. S. Currier). The bulk of the species arrives at St. Louis the last of April or first days of May, when its peculiar, loud song is heard from morning till night and not seldom in moonlit nights. After the song period is over about the middle of July the species is not seen often and its departure is easily unnoticed, but there is little doubt that the majority depart in August and early September (September 1, 1902, and September 2, 1901, Jasper, Mr. W. G. Savage, and September 5, 1903, Shannon Co., by the same observer). That some individuals remain longer has been noticed at St. Louis, where one was met with as late as September 25 at Creve Coeur Lake, St. Louis Co. 
*684. Wilsonia mitrata (Gmel.). Hooded Warbler.

Sylvia mitrata. Setophaga mitrata. Sylvania mitrata. Myiodioctes mitratus. Muscicapa cucullata. Muscicapa selbii (female).

Geog. Dist.-Eastern United States and southern Ontario' north to Connecticut, central Michigan, southeastern Wisconsin, southeastern Nebraska; west to eastern Kansas. Breeds from Louisiana east and northward. Winters from eastern Mexico to Panama.

In Missouri a common summer resident in the southeast, fairly common in the Ozarks, Ozark border and in the bluff as well as bottom lands of the Mississippi and Missouri Rivers, at least as far up as East Leavenworth, Platte Co., where observed by Audubon, May 4, 1843, and by the writer in June 1906. Rare in the prairie region north and west, where suitable localities are getting scarcer and scarcer with the removal of all tree growth from creek and river bottoms. That the species, a denizen of the forest, seems unable to change its habits to conform to the present state of civilization is deplorable, as the bird would be a most desirable ornament to our parks and gardens, being not only one of the most beautiful bircls, but also a fine songster. In the southeast its arrival in spring is much earlier than farther north and has been noticed in Dunklin Co., April 2, 1897, when singing males were already present. At St. Louis the first songs are heard between April 17 and 25, oftenest April 24, and the females arrive from April 28 to 30 . At our northern boundary it arrives in the first week in May. Its cheerful song is heard nearly throughout its sojourn, even to its departure in the latter part of September (September 20, 1897, St. Charles Co., September 28, 1895, Dunklin Co.).

685. Wilsonia pusilla (Wils.). Wilson's Warbler.

Muscicapa pusilla. Sylvania pusilla. Myiodioctes pusillus. Sylvia wilsonii. Setophaga wilsonii. Myiodioctes wilsonii. Sylvia wilsonii. Wilson's Blackcap. Black-capped Warbler.

Geog. Dist.-Eastern North America, north to Newfoundland, Labrador, Hudson Bay and Athabasea; west to eastern edge of Great Plains. Breeds from Nova Scotia, New Brunswick, Maine, northern Minnesota and Manitoba northward and winters on the Atlantic slope of Central America from Guatemala to Costa Rica; no record from South Atlantic and Gulf coast between South Carolina and Texas. 
In Missouri a fairly common transient visitant in all parts of the state, spring and fall. It is one of the later migrants, most numerous in the second week of May, but the first arrivals reach St. Louis May 4 or 5, exceptionally earlier, as April 29, 1885, May 1, 1884, May 2, 1887. It is quite unsuspicious and its song is often heard during the whole of its stay with us. It generally disappears during the third week of May, mostly 17 to 22, but sometimes a loiterer is found later, as May 25, 1882, St. Louis. In 1907 both sexes were unusually numerous from May 11 to 24 incl. On their return journey the first reach us in the latter part of August (August 23, 1897; August 24, 1898; August 25, 1901) and some are met with nearly to the end of September (September 25, 1897; September 27, 1895; September 29, 1887).

685a. Wilsonia pusilla Pileolata (Pall.). Pileolated Warbler. Myiodioctes pusillus var. pileolatus. Sylvania pusilla pileolata.

Geog. Dist.-Western North America, north to Alaska. Breeds in higher mountains from Texas north, and throughout the interior west to eastern Oregon and British Columbia. During migration eastward across the Great Plains to Minnesota, eastern Nebraska, western Missouri. In winter from Yucatan to Costa Rica.

Has been taken at Independence (Ridgway vol. 2, p. 712) and must be regarded as a casual transient visitant along our western border.

686. Wilsonia Canadensis (Linn.). Canadian Warbler.

Muscicapa canadensis. Setophaga canadensis. Myiodioctes canadensis. Sylvania canadensis. Sylvia pardalina. Muscicapa bonapartei (young in autumn). Myiodioctes bonapartei. Sylvania bonapartei. Canada Flycatching Warbler.

Geog. Dist.-Eastern North America; north to Newfoundland, southern Labrador, Hudson Bay, Saskatchewan, Athabasca and Alberta. Breeds from the mountains of North Carolina, the higher parts of New York and New England, southern Ontario, central Michigan, central Wisconsin and central Minnesota northward. Migrates through the wooded districts of the eastern United States, southern Texas, and eastern Mexico and Central America to winter in Ecuador and Peru, 6000 miles from their most northern breeding grounds. 
In Missouri a regular and fairly common transient visitant during spring and fall along the eastern border of the state, the southeast and the counties along the Mississippi River being apparently one of its main thoroughfares. With its sprightly ways and frequent singing it is one of the transient warblers which eannot easily eseape observers, and its absenee from their lists is proof that it must be of rare occurrence in the rest of the state. In the southeast (New Madrid Co.) it was once seen as early as April 10, 1893, but the first reeord for St. Louis is April 28, 1888, unusually early. May 5 to 25 is the regular time of its presenee, most numerous in the middle of the month, and latest dates, May 29, 1897, West Quiney; May 28, 1893, Keokuk. In fall the speeies is with us for fully six weeks from August 15 to September 26, oftenest in the first half of September; latest at St. Louis, October 5, 1905. In the abnormal spring of 1907 both sexes were unusually eommon at St. Louis from May 13 to June 3.

*687. Setophaga Ruticilla (Linn.). American Redstart.

Muscicapa ruticilla.

Geog. Dist.-North Ameriea except Paeific coast district and western portions of Roeky Mountains distriet; north to Newfoundland, Nova Scotia, Hudson Bay, and in the interior to Mackenzie; on the Pacifie eoast to southern Alaska; west to Utah, Idaho, eastern Washington and British Columbia. Breeds from North Carolina, west-eentral Alabama, Arkansas and Indian Territory northward. Winters from the West Indies and Mexieo to Eeuador.

In Missouri a eommon and generaly distributed summer resident in all parts of the state, chiefly in the timber of river and ereek bottoms. Also a very common transient in spring and fall in all kinds of loeations, even in city parks, orehards, cemeteries etc. In the southeast, where it is only fairly common as a breeder, but abundant in migration from the middle of April to the middle of May, it was first noticed April 11, 1893. In the vieinity of St. Louis and most parts of southern Missouri its arrival varies from April 16 to 25, the males always preceding the females and young a few days, the bulk of the spceies, including transients being present from the end of April to the middle of May. At our northern border (Keokuk) the first are usually seen April 30, some years as late as May 6, 1892, 
but very exceptionally as early as April 20, 1896, when even the bulk arrived April 25 (E. S. Currier). Along our western border we have the following dates: Vernon Co., April 24, 1898; Independence, April 27, 1900, and April 30, 1899; Leavenworth, Audubon, May 4, 1843. Fall migration takes place from the middle of August to the end of September, but song is seldom heard after August 25, and young birds predominate in September, though the very last bird seen may be an old male. Last date at St. Louis, October 5, 1906 (a family, adults and young together); Shannon Co., October 10, 1904; Keokuk, October 20, 1900.

\section{Family Motacillidae. Wagtails.}

697. Anthus pensilvanicus (Lath.). American Pipit.

Anthus ludovicianus. Alauda rufa. Anthus spinoletta. Anthus aquaticus. Anthus pipiens. Titlark.

Geog. Dist.-North America, north to Greenland, Alaska and northeastern Siberia. Breeds from Newfoundland, Quebec, high mountains of Colorado and the Sierra Nevada northward and winters from the Gulf States through Mexico to Guatemala.

In Missouri a fairly common transient visitant in April and October, moving in flocks of from thirty to one hundred or more, frequenting plowed fields and burnt-over marshes, and remaining sometimes several weeks in the same locality. It is not known to winter anywhere in the state, but lingers some years much longer than in others as for instance in 1892 , when Mr. Currier met with some as late as December 11, near Keokuk, Ia. That the southward movenent of the Titlarks was exceptionally much protracted in 1892 is also shown by Mr. R. Deane, who found hundreds of them in the marshes at English Lake in northwestern Indiana, November 16, and by a late report from Michigan, October 20, near Detroit.

\section{Anthus spragueir (Aud.). Sprague's Pipit.}

Alauda spragueii. Neocorys spraguei. Missouri Skylark.

Geog. Dist.-In summer from eastern Montana and northern North Dakota northward, chielly on the virgin prairies of Assiniboia; cast rarely to Red River Valley and Manitoba. In winter to southern Louisiana and Texas, south through eastern Mexico to Vera Cruz and Puebla. Occasional to South Carolina. In 
migration through Kansas and Nebraska, rarely west to Wyoming.

This species finds a place in our list on the strength of a single record, it being reported by Mr. Geo. E. Stillwell from Kansas City, Mo., March 20, 1882 (Bird migration in the Mississippi Valley, Forest and Stream, 1882, p. 283). Since it has repeatedly been taken in southeastern Nebraska it stands to reason that its rarity as a transient visitant in Missouri is only apparent and research along our western border will probably be rewarded by discoveries which may enable us to remove it from the rank of great rarities and place it with Baird's Sparrow, McCown's and Chestnut-collared Longspurs among the regular transients.

Family Mimidae. Thrashers, etc.

*703. Mimus polyglottus (Linn.). Mockingbird.

Turdus polygloltus. Mocker.

Geog. Dist.-United States and Mexico; north to Maryland (irregularly to Massachusetts), southern Ohio, Indiana, southern Illinois, Missouri, Nebraska and eastern Colorado; rarely to northern Illinois, Iowa and southern Wisconsin. Breeds throughout its United States range and winters wherever it breeds, but chiefly in the southern states and southward.

In Missouri a fairly common summer resident in the southern half of the state, rarer northward, but reaching the northern border at Keokuk where Mr. Currier found it to be a rare breeder in 1895, '96, '97, '98 and '99. At St. Joseph its occurrence, May 26, 1896, is regarded as accidental by Mr. S. S. Wilson, though it is listed as a common breeder in southern Nebraska. South of the Missouri River the species is partly a permanent resident, rarely north of it, as at Fayette, Howard Co., February 2, 1893. Unfortunately the tendency to winter at its breeding places is a great drawback in the extension of its summer range as many succumb to the severity of our winters. Those that leave us in fall return very irregularly, some in the latter half of March, most of them in April, the last not before early May. Its withdrawal takes place in October. The Mockingbird seeks the friendship of man and where protected becomes half-domesticated. Writing from Alexandria, Clark Co., Mr. Jasper Blines says in Forest and Stream, vol. 31, p. 343: "November 22, 1888. A few southern Mockingbirds reach this 
latitude, appearing in May and going south the latter part of July."

\section{*704. Galeoscoptes carolinensis (Limn.). Catbird.}

Mimus carolinensis. Orpheus carolinensis. Muscicapa carolinensis. Mimus felivox. Turdus lividis.

Geog. Dist.-Eastern North America, north to Nova Scotia, Prince Edward Island, New Brunswick, Quebec, Ontario, Saskatchewan, and through British Columbia to the Pacific; west to and including the Rocky Mountains. Breeds from the Gulf States northward. Winters in the Southern States, Cuba, Central America to Panama.

In Missouri a very common summer resident in all parts of the state except the southeast where it is a rare breeder, but occasionally winters (Dunklin Co., January 15, 1896). The earliest arrivals are reported from the southwest, April 8, 1894, Vernon Co., April 10, 1903, Jasper Co. At Festus, Jefferson Co., it was seen as early as April 15, 1903; at St. Louis, the earliest are April 16 and April 18, but the majority of dates of a long series of years fall in the fourth week of the month, at which time the first Catbirds are usually reported from several stations in central Missouri and during the last days of April also from the northern border. The last days of April and first few days of May is the time when the bulk, the great army, of Catbirds, invade the whole state and become common and conspicuous songsters where before only silent and solitary birds have been seen. Numbers of transient individuals are present, sometimes in small flocks, during the first half of May, when our own Catbirds already have nests and eggs, often beginning to build immediately after the arrival of the female at the close of April. Like its cousin, the Mockingbird, the Catbird is availing itself more and more of the protection which close proximity to human habitation affords, and though its original haunts are the edge of the forests and the fringe along watercourses, it is now found nesting mostly about farmhouses and in gardens and park-like places even in the midst of towns and cities. The return movement of birds from the north sets in about the first of September, when for several weeks Catbirds are again plentiful, but after the middle of the month their numbers vary, some days few are seen, then again many, until the end of the month, when the species becomes rare. At St. Louis the last are noted during the first week of October, rarely 
later when detained by an unusually large crop of wild grapes. Late dates for the state are October 10, 1904, Kansas City; October 20, 1885, Fayette; October 13, 1903, and October 21, 1902, New Haven, Mo.

*705. Toxostoma rufum (Linn.). Brown Thrasher.

Turdus rufus. Orpheus rufus. Harporhynchus rufus. Brown Thrush.

Geog. Dist.-Eastern North America, north to southern Maine, southern Quebec, southern Ontario, Manitoba, Assiniboia and southern Alberta; west to eastern Colorado and eastern Texas. Breeds from the Gulf States northward. Winters in the Southern States.

In Missouri a common summer resident in all well-settled parts; most numerous in the Ozark border and prairie regions, rare in the southeast where all ground-feeding landbirds are rare, and rather scarce in the Ozarks except in localities which have long been settled, where they are fairly common. A few winter in the southeast (January 1896, Dunklin Co.) and some impatient old males return to their breeding stands in southern Missouri quite early (March 1, 1905, and March 10, 1902, Festus, Jefferson Co.; March 9, 1902, New Haven, Franklin Co.). The earliest at St. Louis is March 13, 1882, and March 14, 1880, but from March 20 to 25 is the time when its song is usually heard for the first time at St. Louis and in most parts of southern and east-central Missouri. In the northern and western prairie region Thrashers are seldom heard before April and, since the weather of the first week of April is often cold and unfavorable, usually not before the second week. In some years the northern border has not been reached before the third week (April 20, 1902; April 22, 1890; April 22, 1900, Keokuk). The bulk of the species reaches St. Louis nearly always between the tenth and the fifteenth of April and Keokuk between the seventeenth and twenty-ninth. Transients in small troops pass through mostly in the second weck of April, when the Thrasher is one of the most conspicuous and common songsters in St. Louis. Though not so confiding as the Catbird and Mocker, the Thrasher also comes to nest in our parks and orchards, especially where protected from his many enemies. Its splendid song continues through April and most of May, after which it is only occasionally heard until molt begins in the middle of July. We hear its song again in fall, but only occasionally, as the species remains very quiet 
as a rule all through late summer and fall, withdrawing to localities where it finds wild grapes and different kinds of berries, of which it is very fond. In September large gatherings may be found at such favorite resorts, but after the first of October Thrashers become scarce, though some are present until the 20th, when ordinarily the last is going. Exceptionally an individual may linger into winter, even in north Missouri, where Mr. Parker saw one at Montgomery City as late as December 17, 1904.

\section{Family Troglodytidae. Wrens.}

*718. Thryothorus ludovicianus (Lath.). Carolina Wren.

Certhia caroliniana. Troglodytes ludovicianus.

Geog. Dist.-Eastern United States except Florida and Lower Rio Grande; north to southern New England, southern Michigan, southern Iowa, southeastern Nebraska (where very rare); west to Kansas, Oklahoma and western Texas. Breeds from the Gulf coast northward. Non-migratory.

In Missouri a common resident from the Missouri River southward, fairly common to rare from the counties bordering on the Missouri northward to the state line. At East Leavenworth the writer found it common in June 1906, but Mr. Wilson consiclers it an accidental visitor at St. Joseph, where he captured one April 4, 1896. In the vicinity of Keokuk Mr. Currier found it to be of very irregular occurrence, generally very rare, in 1902 more frequent, therefore thought to be increasing by extending its breeding range. Being a ground-builder the Carolina Wren has been driven from many former haunts by cats, dogs and hogs and may thereby be forced to spread to near regions, but in districts where it is most numerous, as in the southeast and in valleys of the Ozarks, it has learned to place its nests like the House and Bewick's Wrens on porches and about buildings out of reach of cats, dogs and hogs. Excepting an intermission of six weeks during August and September, its cheering song may be heard almost every day of the year, even in midwinter on sunny days. The severity of our winters does not seem to hurt it where, among fallen trees and brush, it is able to secure insect food in any kind of weather. From localities less suited for this purpose it withdraws during the worst part of the season. Being among the earliest breeders finished nests have been found by the middle of March and fully fledged young early in May. 
*719. Thryomanes Bewickin (Aud.). Bewick's Wren.

Troglodytes bewickii. Thryothorus bewickii. Long-tailed House Wren.

Geog. Dist.-Eastern United States, north to New Jersey and Minnesota; rare east of Alleghanies; west to southeastern Nebraska and eastern Texas. Breeds irregularly throughout its range, having its center of distribution in summer in southern Missouri, southern Illinois and southern Indiana and is said to extend its range eastward through Ohio. It winters in the southern United States from southern Missouri southward.

All through the Ozark region and Ozark border the Bewick is the common House Wren, and there is hardly a farm house without its Bewick Wren, while in the towns there is one or more in every square. There it takes the place entirely of the House Wren, which occurs in southeastern Missouri only in counties bordering the Mississippi River. It is not known to oceur in western Missouri outside of the Ozark border region (rare at Jasper, not known at Appleton City, Warrensburg, Independence, etc.). In northern Missouri the species has not been observed west of Howard Co. (Fayette, March 12, 1903), but is reported from Montgomery City and reaches irregularly our northern state line, following the bluff region along the Mississippi to Warsaw, Ill., and Keokuk, Ia., where it was noted April 20, 1896, April 10, 1898, April 9, 1901, and April 19, 1903, with an apparent increase in numbers, according to Mr. Currier. Some winter in southern Missouri even as far north as St. Louis Co. (Old Orchard 1896-1897) and Miller Co. (Iberia, February $3,1905)$, but the bulk retires to more southern regions, returning in March and leaving in October. Being a much better singer and not so meddlesome the Bewick is greatly preferred as a House Wren, but is often clislodged from its nesting site by aëdon, where the two species occur together.

\section{[721. Troglodytes ä̈Don Vieill. House Wren.]}

721b. Troglodites aedon aztecus Baird. Western House Wren.

Sylvia domestica. Troglodytes domesticus. Trogiodytes americanus. Troglodytes fulvus.

Geog. Dist.-The species has lately been split into three subspecies, supposed to intergrade, as otherwise they would have 
to be considered true species; they are the eastern, western and pacific (parkmanii) subspecies. The range of aztecus is said to include Missouri, reaching east as far as the prairie region of Illinois and northwestern Indiana, north to Manitoba and south into Mexico. In winter to Southern States and Mexico. The eastern form occurs in parts of Illinois and southern Wisconsin, but the range limits of the two forms are not fully determined and both may occur in Missouri, the one in the river bottoms, the other in the western and northern prairie region. There is also a possibility of meeting with intermediate forms and the species deserves the special attention of collectors both in migration and breeding time.

Excepting the southeast and Ozark region, where it occurs only in migration, the House Wren is a common summer resident in most parts of Missouri from Ste. Genevieve Co. in the east and Jasper Co. in the west, northward. It breeds together with Bewick's Wren in the Ozark border region and in parts of eastern north Missouri, but is the only House Wren of the prairie region west and northwest. The arrival of the first singing males at their breeding stand occurs with much regularity at St. Louis about April 17, at Independence, April 20, and at Keokuk, April 24. The bulk is a week behind the first, and the last days of April in central, and the first week of May in northern Missouri is the height of the season for singing and mating, as well as for transient, House Wrens. At this time we find House Wrens in company with northern Warblers in localities where they never breed. When between For t Leavenworth and the northeast corner of Missouri, May 5 to May 9, 1843, Audubon wrote in his journal: "The woods were filled with House Wrens." Dr. J. A. Allen, too, found them abundant in that region in May 1871. Although the majority build their nests now in proximity to human habitations, we still find them oceasionally far away from buildings in tree holes, old woodpecker holes, fence posts, etc. They are very meddlesome with other birds' nests and need watching, especially when near a colony of Martins, whose very existence is endangered by the innocent looking Jenny Wren, which destroys the eggs in the absence of the owners. They are industrious songsters, keeping it up all summer, beginning again after a short pause before their departure in September. Single individuals are seen long after the bulk of the species is gone (September 25); the last being reported from Keokuk, October 10, 1893; 
from Jasper, October 10, 1901; from Kansas City, October 8, 1902; from New Haven, October 6, 1902; Mt. Carmel, October 6, 1885; Independence, October 6, 1901; St. Louis, October 6, 1905, and October 14, 1906.

\section{Olbiorchilus hiemalis (Vieill.). Winter Wren.}

Sylvia troglodytes. Anorthura troglodytes. Troglodytes hiemalis. Troglodytes europeus. Anorthura hyemalis. Anorthura troglodytes hyemalis. Troglodytes parvulus hyemalis.

Geog. Dist.-Eastern North America; north to Prince Edward Island, Quebec, Ontario and Manitoba. Breeds from Massachusetts, New York, northern Michigan and northern Wisconsin northward, wintering from the northern states to the Gulf, chiefly south of the Ohio River. Has been found nesting in the Alleghanies south to North Carolina, though rarely.

In Missouri a fairly common transient visitant eastward, rarer westward. (October 7, 1906, Mr. B. M. Stigall of Kansas City found it common in Clay Co. and Mr. Chas. W. Tindall reports it common at Independence. It is also recorded from Warrensburg, January 8, 1905, by Mr. A. F. Smithson, and by W. E. D. Scott, who took two in early April, 1874. As a winter resident it occurs chiefly south of the Missouri River and is particularly numerous in the swampy woods of the southeast. In north Missouri it has been found wintering at Mt. Carmel, Audrain Co, December 14, 1884, and at the northern border near Keokuk, February 17, 1899. In the city and county of St. Louis its wintering has repeatedly been observed, even in severe winters, where it comes to the wood pile on the farm and even to the yards in the city. It begins to leave its southern winter home in the latter part of March, and migration through the state lasts till the middle of April in the southern, and to the end of the month and first week of May in the northern part of the state. In fall migration the first appear at Keokuk sometimes as early as the middle of September (September 16, 1900, September 17, 1893); but at St. Louis not before the first of October. Transients are oftenest met with between October 5 and 20, after which winter numbers only remain. At Shannon Co. in southern Missouri the species was first noted October 15, 1904, by Mr. W. B. Savage of Monteer and by Mr. E. S. Woodruff as late as April 3, 1907, near Ink. 
*724. Cistothorus stellaris (Licht.). Short-billed Marsh Wren.

Troglodytes brevirostris.

Geog. Dist.-Eastern United States and southern Canada, north to southern New Hampshire, southern Ontario, southern Michigan, Wisconsin, Minnesota, Manitoba, and Assiniboia; west to eastern Nebraska, Dakotas, Kansas, Utah. Winters in South Atlantic and Gulf States.

In Missouri a fairly common summer resident in the marshes of the Mississippi and Missouri flood plains and locally in the prairie region north and west, nesting in marsh grass on nearly dry ground and easily overlooked when not in song which may be mistaken for that of the Dickcissel. In the "Spartina" marshes of St. Charles Co. the globular nests are placed in a bunch of that grass near the ground, are made entirely of the blades of that grass and are hidden by drawing together the still standing blades of last year's growth. It reaches its breeding grounds in the last week of April and first of May and remains till November (October 29, 1893, Keokuk). In migration individuals may be met with in places where it is not known to breed and in unexpected locations, as in shrubbery by the wayside in the outskirts of St. Louis. A rather remarkable occurrence is the one reported by Mr. E. Seymour Woodruff, May 14, 1907, from Shannon Co., a mountainous region originally covered by an unbroken forest.

*725d. Telmatodytes palustris iliacus Ridgw. Prairie Marsh Wren.

Troglodytes palustris. Cistothorus palustris. Telmatodytes palustris (part).

Geog. Dist.-Mississippi Valley and northward to Manitoba; east to western Indiana. In winter from western Florida to Vera Cruz along Gulf Coast. This subspecies has only lately been separated from an eastern and a western form, not to mention three more subspecies of the coast regions of South Carolina, Georgia and western Florida, and the Tulé Wren of the Pacific coast.

The Prairie Marsh Wren, generally known by the old name Long-billed Marsh Wren, is a locally common summer resident in lakes and sloughs in which the Cat-tail family, Typha and Sparganium, grows in abundance. Its globular nests are placed in these reeds above water and are made of the dead leave 
of these plants, differing greatly from the neat structures of the Short-billed cousin, made of narrower grass blades. It begins to show on its breeding grounds about the middle of April (April 11, 1903, Kansas City; April 19, 1903; Montgomery City), but, waiting for the growth of its favorite reeds, its numbers increase slowly and reach full force only a month later (May 11, 1897, May 16, 1898 and 1899, Keokuk). When overtaken by storms at night in migration, it may be encountered in places far from water, its only true home. Fall migration begins in the middle of September and lasts through October into November, the last ones being noted as late as November 12, 1893, November 16, 1897, and November 21, 1899, in Clark Co. by Mr. Currier. Like that of the Short-billed Marsh Wren the capture of three specimens of this species, May 9, 1907, in Shannon Co. by Mr. E. S. Woodruff deserves particular mention as hardly expected in that high and wooded region.

Family Certhimae. Creepers.

*726. Certhia familiaris americana (Bonap.). Brown Creeper.

Certhia familiaris. Certhia americana. Certhia familiaris rufa.

Geog. Dist.-Eastern North America, north to Newfoundland, Nova Scotia, New Brunswick, Quebec, Ontario, and Manitoba; west to Dakotas, eastern Nebraska, Indian Territory and Texas. Breeds from Massachusetts, New York, northern Indiana, northern Wisconsin, eastern Nebraska, southeastern South Dakota northward; also along higher Alleghanies from North Carolina northward and in the Cypress swamps of the lower Mississippi Valley. Winters from the northern United States southward, but chiefly south of the Ohio River to northern Florida and central Texas.

In Missouri the Creeper is a common transient visitant in all parts of the state for a short time in spring and fall; also a common winter resident in the heavily wooded southeast, but of less regular occurrence in winter in other parts of the state, especially in the northern, where it is rather rare except in the timber of river bottoms. In migration it occurs everywhere, even in cities, but does not stay long in one place seeming to be in haste to proceed toward its destination. In spring the first stir northward is noticeable about March 10 , but little progress 
is made until the last week of the month or early in April, when migration on a large scale takes place in eentral Missouri, reaching the northern border about the middle of April. Its progress depends much on the weather; if favorable, the last has passed the region of St. Louis by the 10th, but if windy and eold, a not unfrequent occurrence in early April, it may still be present at the beginning of the third week, exceptionally even later, as April 26, 1S85. At Keokuk most of "lasts" reported are from April 16 to 25. In the abnormally eold spring of 1907 a Creeper was seen and heard to sing by Mr. Roger N. Baldwin and the writer at St. Louis as late as May 19. In fall migration the first Creepers reach Missouri from the north in the fourth week of September (September 21, 1884, Mt. Carmel; September 24, 1887, St. Louis); but they do not become common until Oetober, when generally in the seeond week of that month the bulk passes through the state. After the middle of November winter numbers only are left, remaining not only in mild but also in severe winters as that of 1904-1905 (January 23, 1905, St. Louis; January 1, 1905, Warrensburg). That the Brown Creeper is a breeder in the Bald Cypress (Taxodium) swamps of the south was unknown until a nest with eggs was found by the writer at Cotton Plant, Dunklin Co., June 2, 1894, in the overflow of the Little River (Auk vol. 12, 1895, p. 350). Subsequent visits to the southeast showed that the species is a regular inhabitant of the region, wherever old Cypress trees are found, under the loose bark of which the nests are placed (May 16, 1898, three nests were found in Seneea slough, Dunklin Co.). On its breeding ground in the swamp the Creeper is one of the most diffieult birds to detect, as it frequents the higher branches of trees and remains so well hidden that it is almost impossible to see it, even while it gives its shrill song repeatedly. This resembles at a distanee some notes of the Carolina Chickadee, for which it may be mistaken by one who does not suspect the presence of the Creeper.

Family Sittidde. Nuthatehes.

*727. Sitta Carolinensis Lath. White-breasted Nuthatch.

White-bellied or Carolina Nuthatch.

Geog. Dist.-Eastern North America, north to Newfoundland, Anticosti and Keewatin; west to eastern edge of the Great Plains, replaced westward by the subspeeies nelsoni, the Rocky Mountain 
Nuthatch. Breeds from Georgia and the Gulf States (except coast belt) northward. Non-migratory except in the more northern portions of its range.

In Missouri a common resident inhabiting the woods in the breeding season and visiting orchards, gardens, cornfields and farms in winter often in company with Chickadees, Tufted Tits, Downies and others. It is generally distributed all over the state, but appears scarce during nesting time (which begins in the latter part of March in the southern and the middle of April in the northern portion) on account of retiring habits in sharp contrast to its conspicuousness at the time of mating.

728. Sitta canadensis Linn. Red-breasted Nuthatch.

Sitta varia. Red-bellied or Canada Nuthatch.

Geog. Dist.-North America at large, breeding in the higher Alleghanies, the Rocky Mountains, the Sierra Nevada, and from New England, New York, Pennsylvania, northern Indiana, northern Illinois, central Iowa, northward to Prince Edward Island, Keewatin and the Yukon district. In winter south to the Gulf states, New Mexico and Arizona, probably northern Mexico.

In Missouri an irregularly common transient visitant, especially irregular in fall when it has been recorded at St. Louis all the way from September 4 to January 15 . More regular in spring, when it is more or less common from April 25 to May 15 (1904). Some may spend the whole winter in the pine region of the Ozarks, but at St. Louis the species has never been seen between January 15 and April 15, nor is there any other record from the state at hand.

Since the above was written Mr. E. Seymour Woodruff found the species March 11, 14, 24, 30,1907, in the pine region of Shannon Co., Mo., and occasionally up to April 27, when the last was scen, except one each day, May 1, 9 and 12. Here may also be added another unusually late record May 21, 1907, at St. Louis, but the extraordinary cold spring shifted all dates out of recognition.

*729. Sitta pusilla Lath. Brown-headed Nuthatch.

Geog. Dist.-Pine region of southern United States from Maryland to eastern Texas. Casually northward to St. Louis, Ohio, Michigan, New York and the Bahamas. 
This species was at first regarded as a rare straggler after being found by the writer May 6, 1878, in a private park in the southern part of St. Louis and reported in Nutt. Bull. vol. 5, p. 191. It was always suspected to be a regular resident in the pine region of southern Missouri, but proof was wanting until Mr. E. Seymour Woodruff took a pair March 19, 1907, near Ink, Shannon Co., Mo.

Family Paridae. Titmice.

*731. Baeolophus bicolor (Linn.). Tufted Titmouse.

Parus bicolor. Lophophanes bicolor. Tufted Tit. Crested Tit.

Geog. Dist.-Eastern United States, north to New Jersey, Ohio, Indiana, northern Illinois, southern Iowa and northeastern Nebraska: irregularly farther north to Minnesota ete.; west to the Great Plains (Nebraska to Texas). South to Gulf coast from central Florida to central Texas. Nonmigratory, but wandering about during fall and winter in search of food, thus appearing in places not inhabited in breeding time.

In Missouri a common and generally distributed resident, much more numerous southeast than northwest, most abundant in the high trees of the river bottoms, but inhabiting also the dry hills of the Ozarks and the wood patches in the prairie region. Removal of old and decaying trees has driven it from many localities by depriving it of its accustomed nesting sites, natural cavities in trees or deserted woodpecker holes. Orchards and parks should be provided with bird boxes fit for its use in order to attraet and retain this useful bird, one of the most efficient insect-destroyers, killing millions of noxious insects in the egg statc all the year round.

*735. Parus atricapillus Linn. Chickadee.

Parus palustris. Penthestes atricapillus atricapillus. Black-capped Chickadee.

Geog. Dist.-Northeastern United States and southeastern British Provinces; north to Newfoundland, southern Labrador, Quebec, Ontario and southern Keewatin; south to lat. $40^{\circ}$ in the Eastern States and through the prairie region of northern and western Missouri to eastern Kansas; also in Alleghanies to North Carolina. Partly migratory, wandering to localities far from breeding ground in search of food, southward in fall, return- 
ing in early spring, thus appearing in the role of a migrant in the region immediately south of its breeding range.

The Black-capped Chickadee is a common resident north and west of the Ozark border region, being replaced south and eastward by the Carolina Chickadee, and blending into the longtailed subspecies, or a form which connects the two subspecies, in the western and northwestern counties. In St. Louis Co., where the Carolina Chickadee is the prevalent form or species, the Black-capped appears regularly and numerously in family troops in October and again in March, some remaining with us, but the majority spending the winter farther south. In the northern part of St. Louis Co., in the flood plain of the Missouri River about Creve Coeur Lake, the Black-cap and the Carolina Chickadee have both been found breeding, but at St. Louis and southward the Carolina only is seen in summer.

\section{*735a. Parus atricapillus septentrionalis (Harris). Long-} tailed Chickadee.

Parus septentrionalis. Parus atricapillus (in part). Penthestes atricapillus septentrionalis.

Geog. Dist.-Great Plains and Rocky Mountain districts of central North America from New Mexico and Kansas to Alaska and Mackenzie; east to eastern Kansas, Iowa, eastern South Dakota, western Minnesota, Manitoba and southwestern Keewatin; west to Salt Lake.

Dr. Hoy mentions the Long-tailed Chickadee among the birds observed by him in western Missouri in 1854, and W. E. D. Scott (Nutt. Bull., vol. 4, p. 140), who took a large series of Chickadees in Johnson Co. in 1874, found that many approached the subspecies, septentrionalis. in having the secondaries and lateral tail feathers conspicuously edged with white. Mr. B. F. Bush of Courtney, Jackson Co., writes me: "The Longtailed Ch. occurs here much of the time and undoubtedly breeds." Mr. H. Nehrling also reports this form as occurring, though rarely, together with atricap. and carolinensis at Pierce City, Lawrence Co. In Atchison Co. (Langdon, Rockport etc.) this was the only form found by the writer in June, 1906 .

*736. Parus carolinensis Aud. Carolina Chickadee.

Parus atricapillus carolinensis. Penthestes carolinensis.

Geog. Dist.-Eastern United States north to southern New Jersey, southern Pennsylvania, southern Ohio, southern Indiana, 
central Illinois, central Missouri. South to northern and western Florida and along Gulf coast to Louisiana, replaced westward by the subspecies agilis. Non-migratory.

In Missouri a common resident of the Ozark and Ozark border region and the southeast, apparently running in the extreme southwest (MeDonald Co.) into the subspecies agilis, which is slightly larger with clearer gray on upper parts.

[736a. Parus Carolinensis Agilis Senu. Plumbeous Chickadlee.]

Geog. Dist.-Eastern and central Texas, Indian Territory and Oklahoma.

This subspecies was noticed, though not collected, by the writer at Noel, MeDonald Co., June 1905, and eollectors should try to verify the observation when eollecting in that region.

\section{Family Sxifidae. Kinglet, Gnateatchers.}

748. Regultes satrapa Licht. Golden-eromed Kinglet.

Regulus cristatus. Sylvia regulus. Regulus tricolor. Regulus reguloides.

Geog. Dist.-North America east of Rocky Mountains; north to Cape Breton Islaurl and Prince Edward Island, Labrador, Keewatin and westward to Rocky Mountains;replaced in western North America by the subspecies olivaceus. Breeds from Massachusetts, central New York, northern Michigan northward; also along Alleghany Mountains to North Carolina. Winters from the northem states southwari to northern Florida and along Gulf coast to south central Texas, but chiefiy south of the Ohio River.

In southern Missouri a fairly common winter resident, rather rare in winter in the northern and western part of the state (Warrensburg, January 17, 1905, A. F. Smithson). As a transient visitant eommon for a short time in the whole state, especially eastward. Migration begins in favorable weather by the middle of Mareh (March 12, 1857, St. Louis) and the first reach the northern border sometimes in Mareh (March 20, 189t, March 26, 1893, Keokuk) but usually in the second week of April, when the bulk of the speeies is present at St. Louis. The weather permitting, the specics passes rapidly on and in most years none are seen in the state after the middle of April, but 
exceptionally some remain to near the end of the month (April 29, 1904, and April 22, 1888, St. Louis). In fall migration forerunners appear sometimes in September (September 24, 1901, Keokuk; September 29, St. Louis), but usually not before early in October, sometimes even in the second week of that month. At St. Louis the bulk is present between the tenth and twentieth of October, when troops of 12 or more are not very rare. The last transients are seen near the end of the month, seldom lingering into the first week of November (November 4 and 6, 1894, Keokuk).

\section{Regulus Calendula (Linn.). Ruby-crowned Kinglet.}

Sylvia calendula. Regulus calendulus.

Geog. Dist.-North America, north to the limits of tree growth, to Prince Edward Island, Labrador, Keewatin, Mackenzic, Yukon and Alaska. Breeds from Quebec, Mackinac Island and high mountains of New Mexico and Arizona and from northern California northward and winters entirely across United States and over whole of Mexico to Guatemala, ehiefly from the Ohio River and southeastern Missouri southward and throughout California.

In Missouri a common and generally distributed transient visitant, and a winter resident southward. Occasionally one is seen in midwinter in the vicinity of St. Louis, but its real winter range begins in the heavy forests of the southeast, wherc the species is quite common throughout winter. The first Ruby-crowns arrive from the south soon after the middle of March (March 19, 1907, Shannon Co., Woodruff; March 20, 1886, St. Louis; Mareh 20, 1898, Independence; March 23, 1889, Laclede, Linn Co.; Mareh 24, 1893, Keokuk) and the bulk is present between April 4 and 20. The "lasts" are usually seen, in all parts of the state, early in May, but loiterers are sometimes met with in the second week of that month (May 9, 1882, and May 13, 1907, St. Louis; May 10, 1905, Shannon Co., Savage; May 14, 1905, LaGrange, Johnson; May 15, 1898, Keokuk, Currier). In fall the first come to the state from the north about the middle of September (September 14, 1901, Jasper Co.; September 16, 1887, St. Louis), but it is always rare until the last week of the month, when it appears more regularly. In some years it has not been seen at St. Louis before October 5 , when the bulk is generally present in all parts of Missouri, 
remaining until October 15 , after which date the species becomes scarce, and the last disappear between October 20 and 25 (October 26, 1889, Independence; October 25, 1894, Keokuk).

*751. Polioptila Caerulea (Limn.). Blue-gray Gnatcatcher. Muscicapa caerulea. Culicivora caerulea.

Geog. Dist.-Eastern United States and southem Ontario, north to New Jersey, Pennsylvania, southern Michigan, southern Wisconsin, and eastern Nebraska. Breeds from Florida and southern Texas northward and winters from the Gulf States, Bahamas, Cuba and eastern Mexico to Yucatan and Guatemala.

In Missouri a summer resident, less common in the prairie region, but common throughout the Ozarks and Ozark border region as well as in the swamps of the southeast and in the bluffs and bottoms along rivers. It begins to arrive in the southeast, sometimes also in central Missouri, in the latter part of March (March 18, 1904, Iberia, Miller Co.; March 25, 1907, St. Louis). On account of the very uncertain weather in early April the first appearance at its breeding stands varies considerably and its ranks fill up slowly. In some years it has not been seen at St. Louis before the end of the second week in April, when, as a rule the bulk is due in central Missouri. The earliest date at our northern border is April 12, 1903, and the latest of "firsts" April 29, 1894; and the same variations occur at every recordstation (Mt. Carmel, April 5, 1885, and April 24, 1886). In fall the species withdraws from breeding haunts comparatively early, as it is quite rare after the first week of September, though occasionally loiterers have been noted much later, as September' 25, 1885, at St. Louis; September 30, 1903, at New Haven: October 1, 1904, at Monteer, Shannon Co.

Family TurdidaE. Thrushes, Bluebirds, etc.

Subfamily Turdinae. Thrushes.

*755. Hylocichla mustelina (Gmel.). Wood Thrush.

Turdus mustelinus. Turdus melodus.

Geog. Dist.-Eastern United States and Ontario; north to Massachusetts, southern Michigan, central Wisconsin and Minnesota; west to eastern Nebraska, eastern Kansas and Texas. 
Breeds from Florida, Louisiana, Arkansas and Indian Territory northward. Winters in Cuba and Guatemala.

In Missouri a common and generally distributed summer resident in all parts of the state high and low, north and south, east and west. Formerly a true woodland species it has accustomed itself to the new conditions and feels at home wherever there are trees, even in cities, often building its nest within a few yards of occupied dwellings. At the southern border, in Dunklin Co., the first Wood-Thrush was heard to sing as early as April 3. At St. Louis and in central Missouri generally, also in the higher parts of southern Missouri, the first are heard to sing between April 18 and 24, at the northern border between April 25 and 30. Exceptions are rare, and the bulk is usually present in the last days of April southward and the first week in May northward, when transient individuals swell their numbers and the song of the Wood-Thrush is heard everywhere. Migrants from the north are with us during the first half of September, but the bulk of the species leaves entral Missouri about the middle of the month and nearly all are gone before the end of the month, except in the southern part of the state, where some linger through the first decade of October (St. Louis, October 7, 1905; New Haven, October 9, 1903; Jasper, October 10, 1902; Monteer, October 10, 1904).

756. Hylocichla fuscescens (Steph.). Wilson's Thrush.

Turdus fuscescens. Turdus wilsonii. Veery. Tawny Thrush.

756a. Hylocichla fuscescens salicicola Ridgw. Willow Thrush.

Turdus fuscescens salicicolus.

Geog. Dist.-The breeding range of the two subspecies has not yet been clearly defined. While the Wilson's breeds in eastern North America from southern Alleghenies and about $40^{\circ}$ lat. northward to Nova Seotia and Ontario, the Willow Thrush's summer home is not only in the Rocky Nountains from New Mexico and Arizona north to British Columbia, but reaches eastward through Manitoba and northwestern Ontario, where they are slightly intermediate, to Newfoundland.

This peculiar overlapping of the breeding areas must produce a crossing of migration routes, which makes it at priesent difficult to say to which of the two forms the majority of transients belong that regularly pass through our state in spring 
and fall. That both forms occur is certain, as there is one specimen of salicicola taken at Charleston, Mo., May 9, 1879, in the Bryant colleetion at Cambridge, Mass., and others have been taken in eastern as well as western Iowa and in northern Illinois. Without having the bird in hand it is difficult, though not impossible, to tell the subspecies, and it is for this reason that it will be the work of future collectors in our state to define their status. Mr. Chas. K. Worthen says salicicola is the commoner one at Warsaw, Ill.

In Missouri a regular, but nowhere numerous, transient visitant, seattered over the entire state and through a whole month in spring and in fall, from April 20 to May 24, and from September 4 to October 10 , but most common from May 10 to 17 and from about September 9 to 12 (Earliest April 20. 1902, Jasper; latest October 10, 1904, Monteer; both reported by $\mathrm{W}^{*}$. G. Savage).

\section{Hylocichla aliciae (Baird). Gray-cheeked Thrush.}

Turdus aliciae. Turdus swainsoni aliciae. Turdus ustulatus aliciae. Alice's Thrush.

Geog. Dist.-Eastern North America to the Aretic coast, Alaska and eastern Siberia. Breeds far north and migrates through eastern United States, ehiefly the Mississippi Valley, to Costa Rica.

In Missouri one of our common and most regular transient visitants spring and fall, less eommon westward. The vanguard arrives in southern Missouri in the last week of April; at St. Louis about the first of May, and the bulk is present during the second and third week of May; "lasts" are generally recorded in the fourth week, but individuals have been found lingering into June, even in the southeastern corner of the state, where the ripening of the Mulberries, of which they are very fond, accounts for the delay. They are generally in company with Olive-backed Thrushes and with them visit in spring all kinds of places, coming even into gardens in towns and on the lawns in cities. They are often heard to sing at half voice, are very confiding and remain at the same place several days, in cool weather a week or more. In fall they frequent other localities, chiefly the timber in the bottomlands, where they find different kinds of berries and thick shelter for roosts. They are sometimes found quite early in September, but the bulk is present in the 
third and fourth weeks of the month, and the last do not leave our most southern woods before the middle of October. While they are musical in spring, they are silent in fall and therefore easily overlooked, but may be found wherever there are plenty of wild grapes, hackberry, sour gum, and other wild fruit.

[757a. Hylocichla aliciae Bicknelli Ridgw. Bicknell's Thrush.]

Turdus aliciae bicknelli.

Geog. Dist.-Breeds in mountainous parts of northeastern states and Nova Scotia.

Has been taken several times at Warsaw, Ill., by Mr. Chas. K. Worthen; the first time, May 24, 1884, and identification verified by Mr. R. Ridgway himself (Natural History Survey of Illinois, vol. 1, page 59). Mr. Worthen thinks that it will undoubtedly be found in company with Gray-cheeked Thrushes on wooded islands in the Mississippi while migrating in April and May.

758a. Hylocichla ustulata swainsoni (Cab.). Olive-backed Thrush.

Turdus swainsonii. Turdus ustulatus swainsonii. Swainson's Thrush.

Geog. Dist.--Not considering the lately differentiated subspecies oedica and almae the Swainson's Thrush ranges over Eastern North America and westward to the upper Columbia River, straggling to the Pacific coast into the domain of the other subspecies ustulata. Breeds from the mountainous parts of the eastern states and from Mackinac Island north to Newfoundland, Gulf of St. Lawrence, Hudson Bay and through the Saskatchewan region to Mackenzie and westward to British Columbia, rarely to Alaska. In winter to Cuba, and through Central America to Colombia, Ecuador and Peru.

In Missouri a common and most regular transient visitant spring and fall, west as well as east. In some springs the first are seen in southern Missouri soon after the middle of April, but the cold and windy weather which we often have about this time keeps them from advancing farther until the last days of the month, when they usually appear in the vicinity of St. Louis (April 26, 1883, 1884). The bulk is always present between May 3 and 15, after which their numbers decrease more or less rapidly according to the weather, the last being noted in the 
fourth week of the month, latest May 29, 1882, June 3, 1907, St. Louis. In Shannon Co., where Mr. Savage found them extremely abundant, they occurred from April 22 to May 16, 1904, and from April 30 to May 10, 1905. At Keokuk Mr. Currier found them commonly about the middle of May (May 6, 1892 to Hay 17, 1893). At Grandin, Carter Co., Mr. E. S. Woodruff found it as late as May 25, 1907. Fall migration extends from September 5 to October 3 , the bulk being present about September 20.

\section{9b. Hylocichla guttata pallasil (Cab.). Hermit Thrush.}

Turdus solitarius. Turdus minor. Turdus pallasii. Turdus aonalaschkae pallasii. Hylocichla unalascae pallasii.

Geog. Dist.-Eastern North America, north to Newfoundland, Anticosti and the north shore of the St. Lawrence, southern Ungava and west of Hudson Bay to Mackenzie and Yukon; west to British Columbia. Breeds from the mountainous parts of the eastern United States and from northern Michigan and northern Minnesota northward. Winters from southern New Jersey and the Ohio River southward to the Gulf coast.

In Missouri a fairly common, and generally distributed transient visitant, and a winter resident in the heavily wooded southeast. In its migration it reaches St. Louis sometimes in March (March 25, 1907; March 30, 1887; March 31, 1905), but more commonly early in April, and the bulk is usually present in the second and third week of the month. "Lasts" are noted in the fourth week, latest April 27, 1887, and May 1, 1907. Mr. E. S. IVoodruff found the Hermit Thrush in Shannon Co. March 26 to April 27, 1907. Mr. Currier's earliest date at Keokuk is April 10, 1898; his last April 28, 1893. In fall it reaches Missouri early in October (October 5, 1885, St. Louis; October 5,1904 , Shannon Co., Savage); the bulk is present in the second and third week, and the last at St Louis, October 25. It comes back to the same resting places year after year, remains a few days, sometimes a whole week, and goes on. It is seldom heard to sing in transit, but may be heard in its winter home, where it frequents the same swampy ground as the Winter Wren adjoining the drier haunts of the Fox, White-throated and other sparrows. (The Peninsula of Missouri as a Winter Home for Birds, by O. Widmann, Auk, 1896, vol. 13, p. 216). 
*761. Merula migratoria (Linn.). American Robin.

Turdus migratorius. Robin. Robin Redbreast.

Geog. Dist.-Eastern North Ameriea from eastern Mexico to Alaska; west to the Rocky Mountains where it runs into the western subspecies propinqua. Breeds from Virginia and Arkansas northward to the Arctic eoast; winters from southern New England, southern Indiana, southern Illinois, central Missouri and southeastern Nebraska southward to the Gulf; in mild winters some have wintered as far north as South Dakota, Minnesota, Miehigan and southern Ontario.

In Missouri the Robin is an abundant migrant and a very common summer resident in all parts of the state, south as well as north, wherever there are farms, towns and eities, which it now prefers to the wilds during nesting time, but retreating to them in fall and winter. Some spend the whole winter, even severe winters, in the lower Missouri River valley and along the Mississippi River from the Illinois River southward, but the largest number is found in the swamps of the southeast, where many more would remain if they were not constantly disturbed by the host of cluck hunters who repair to those regions. When the weather shows the first signs of awakening spring, sometimes at the end of January, oftener about the middle of February, the first troops of north-bound Robins appear in central, and a week or two later, in northern Missouri. Early in Mareh the first males begin to sing in their old haunts, are soon joined by their mates, and bravely endure weeks of eold weather with ice, sleet and snow or chilling rains and high winds. Large flocks of transient Robins are also with us during the entire month of March and to the latter part of April, when in some years the young of our own birds are almost able to leave the nest (First egg, April 5, 1903, Montgomery City, Parker; young leave nest May 1, 1886, Fayette, Kilpatrick). When the last broods are able to fly well, about the first of Augist, Robins for'm small family troops, several of which join to spend the nights together in a common roost. When migration time comes in Oetober larger roosts are formed, in which many thousands spend the nights together like Blackbirds in the high grasses of the marshes (A Winter Robin Roost in Missouri, by O. Widmann, Auk, vol. 12, 1895, page 1). By the first of November the bulk of transient Robins has left north and central Missouri, but many linger in the bottoms of our large rivers to the middle and often to the end of the month, even in northern portions of the state. 
The immense stretches of wild rice in the swamps of the southeast offer a safe place for roosts at this time of the year and flocks of many thousands have been seen to assemble there. They are great rovers, leave the roosts at daybreak and do not return before evening, spreading during the day over a large territory in scarch of food.

*766. Sialia sialis (Linn.). Bluebird.

Sylvia sialis. Ampelis sialis. Sialia wilsonii.

Geog. Dist.-Eastern United States and southern Canada, north to Newfoundland, Nova Scotia, New Brunswick, Quebec, Ontario and Manitoba; west to base of Rocky Mountains. Breeds throughout its range and winters chicfly in the Southern States, though in small numbers from southern New England, Indiana and central Missouri southward.

In Missouri a common summer resident in all parts of the state from March till October and a fairly common winter resident in the southeast, where it occurs in small troops, which seek the woods for shelter and the fields and clearings for food. Small parties also winter from St. Louis southward, retiring to the bottoms, where they spend the nights in woodpecker holes, often several together in one hole, visiting their summer haunts only in warm weather for a short time on spring-like mornings, but may thus be seen and heard even at Christmas and New Year's time. In mild winters a few have been found wintering in New Haven, Fayette, Glasgow, Warrensburg and even at Laclede in Linn Co. (January 19, 1889, Ong). Migration begins usually between February 15 and 25 and the first reach even tho most northern counties in the last days of February or in the first week of March. The transit of parties of north-bound Bluebirds continues until the latter part of March. Our own Bluebirds have by this time taken up their old quarters, finished nests being found as early as March 20, where, if not disturbed, they remain until the last brood is ready to go, about the first of August, when all retire to favorite feeding grounds. Three broods are sometimes made, the first leaving the nest about May 12, the second June 24, the third August 1. Migration from the north reaches us about the first of October and in the second and third week of the month Bluebirds are present in flocks of different size, sometimes as many as three hundred together apparently ready to depart for more southern climes. The bulk 
of the species is gone by November 1 , but some linger through November even in northern Missouri. After. December 1 winter numbers only are left. We sometimes read that no bird has suffered so much from perseeution by the English Sparrow as the Bluebircl. While this may be true in some parts of the country, the Missouri Bluebird has not much to fear from the Sparrows; it ean cope with them suceessfully. After a pair has once taken possession of a bircl-box no English Sparrow is allowed to come within ten feet of it. The greatest enemy of the Bluebird is the house cat, which gets most of the young birds the very first day they leave the nest, being eareless enough to fly to the ground, but not strong enough to fly up readily when the lurking pet of the household approaches. 


\section{INDEX.}

Acanthis linaria 169

Accipiter atricapillus 93

cooperii 92

fringilloides 91

fuscus 91

mexicanus 92

pensylvanicus 91

velox 91

Actitis macularius 74

Actiturus bartramius 73

Actodromas bairdii 68

fuscicollis 68

maculata 67

minutilla 69

Aechmophorus occidentalis 21

Aegialites vociferus 76

Aegialitis meloda cireumeincta 77

semipalmata 77

vocifera 76

Aegiothus fuscescens 169

linaria 169

Agelaeus phoeniceus 155

Agelaius phoeniceus 155

fortis 156

xanthocephahus 154

Ainophila aestiva bachmani 189

Aix sponsa 37

Alauda alpestris 142

cornuta 142

magna 156

rufa 243

spraguei 243

Alcedo alcyon 118

Ammodramus bairdii 176

bimaculatus 178

caudacutus 179

nelsoni 179

henslowii 178

leconteii 179

nelsoni 179

palustris 191

passerinus 177

sandwich. alaudinus 176 savanna 175

savannarum 177

perpallidus

178
Ampelis americana 205

cedrorum 205

garrulus 205

sialis 265

Anas acuta 36

albeola 40

americana 33

boschass 31

caerulescens 45

canadensis 45

carolinensis 34

eaudacuta 36

clangula 39

clypeata 35

collaris 39

columbianus 48

crecea 34

cyanoptera 35

discors 34

domestica 31

ferina 37

fuligula 39

fulva 47

fusca 42

glacialis 41

histrionica 41

hyemalis 41

hyperboreus 44

islandica 40

jamaicensis 43

longicauda 41

marila 38

minuta 41

nigra 42

obscura 32

penelope 33

rubripes 32

perspicillata 43

rubidus 43

rufitorques 39

sponsa 37

strepera 32

vallisneria 37

Anhinga anhinga 27

Anorthura hyemalis 250

troglodytes 250

hyemalis 250 
Anser albatus 44

albifrons 45 gatmbeli 4.5

caerulescens 45

frontalis 45

gambeli 45

hutchinsii 46

hyperboreus 44

Antrostomus carolinensis 128 nuttallii 129 vociferus 128

Anthus aquaticus 243

ludovicianus 243

pensilvanicus 243

pipiens 243

spinoletta 243

spragueii 243

Aquila canadensis 100

chrysaẻtos 100

fulva 100

leucocephala 100

Archibuteo ferrugineus 99

lagopus 99

$$
\text { sancti-jolrannis } 99
$$

Ardea americana 56

caerulea 54

candidissima 54

egretta 53

exilis 52

herodias 52

leucogastra $\mathrm{v}$. leucophrymna 54

ludoviciana 54

minor 51

naevia 55

pealei 54

rufa 54

rufescens 54

stellaris canadensis 51

tricolor ruficollis 54

virescens 55

Ardetta exilis 52

Arenaria morinella 78

Arquatella maritima 67

Asio accipitrinus 106

wilsonianus 105

Astragalinus tristis 169

Astur atricapillus 93

cooperii 92

liyemalis 97

palumbarius 93
Astur pennsylvanicus 91, 98 velox 91

Avocet, American 63

Aythya affinis 38

americana 37

collaris 39

marila 38

nearctica 38

vallisneria 37

Baeolophus bicolor 255

Baldpate 33

Bartramia longicauda 73

Beach Bird 70

Bee Martin 135

Beetle-head 76

Bernicla canadensis 45

lutelinsii 46

Bird of Paradise 135

Washington 100

Bittern, American 51

Least 52

Little 52

Blackbird, Brewer's 163

Common 163

Crow 163

Red-winged 155

Rusty 162

Swamp 155

Thrush 162

Yellow-headed 154

Blackeap, Wilson's 240

Black-head, Big 38

Little 38

Black-jack 39

Bluebill, Big 38

Little 38

Bluebird 265

Blue Jay 144

Bobolink 149

Bob-white 78

Bombycilla americana 205

carolinensis 205

garrulus 205

Bonasa umbellus 79

Botaurus lentiginosus .51

minor 51

mugitans 51

Brachyotus palustris 106

Brant, White 44 
Branta canadensis 45

hutchinsi 46

minima 47

Bridge-pewee 137

Bristle-tail 43

Brown Back 66

Bubo virginianus 110

pallescens 112

subarctica 112

Bucephala albeola 40

americana 39

elangula 39

Buffle-head 40

Bull-bat 130

Bull-head 76

Bull-peep 68

Bunting, Bay-winged 175

Black-throated 198

Henslow's 178

Indigo 196

Lark 198

Lazuli 197

Painted 197

Butcherbird 206

Buteo aquilinus 94

bairdii 97

borealis 94

calurus 96

harlani 96

kriderii 95

calurus 96

harlani 96

hyemalis 97

lagopus 99

latissimus 98

lineatus 97

montanus 96,97

niger 99

pennsylvanicus 98

platypterus 98

swainsoni 97

vulgaris 97

Butorides virescens 55

Butterball 40

Buzzard, Red-shouldered 97

Red-tailed 94

Rough-legged 99

Turkey 86

Calamospiza bicolor 198
Calamospiza melanocorys 198

Calcarius lapponicus 173

ornatus 174

pictus 173

Calico-back 78

Calidris arenaria 70

caliclris 70

rubidus 70

Campephilus principalis 119

Canary, Wild 169, 222

Canvasback 37

Caprimulgus carolinensis 128

nuttallii 129

popetue 130

virginianus 130

vociferus 128

Carbo mexicanus 28

Cárdinal 194

Kentucky 194

Cardinalis cardinalis 194

virginianus 194

Carduclis americanus 169

carduelis 171

clegans 171

pinus 170

tristis $\mathbf{1 6 9}$

Carpodacus purpureus 167

Catbird 245

Catharista atrata 87 urubu 87

Cathartes atratus 87 aura 86

Cedarbird 205

Centronyx bairdii 176 ochrocephalus 176

Centrophanes lapponicus 173 ornatus 174 pictus 173

Centurus carolinus 126

Ceophlous pileatus 123

albieticola 123

Certhia americana 252

caroliniana 247

familiaris 252

americana 252

rufa 252

maculata 212

pinus 216

varia 212

Ceryle alcyon 118 
Chaetura pelagica 132 pelasgia 132

Charadrius apricarius 76 dominicus 76

fulvus v. virginicus 76 helveticus 76 hiaticula 77 marmoratus 76 melodus 77 mexicanus 64 pluvialis 76 semipalmatus 77 virginicus 76 vociferus 76

Charitonetta albeola 40 Chat, Yellow-breasted 239

Chatterer, Bohemian 205

Chaulelasmus streperus 32

Chebeck 142

Chelidon erythrogastra 202

Chen caerulescens 45

hyperborea 44

hyperboreus albatus 44 nivalis 44

Cherrybird 205

Chewink 193

Chickadee 255

Black-capped 255

Carolina 256

Long-tailed 256

Plumbeous 257

Chippy 184

Winter 184

Chondestes grammacus 180 grammica 180

Chordeiles henryi 131 popetue 130 virginianus 130 henryi 131 sennetti 131

Chroicocephalus franklini 25 philadelphia 25

Chrysomitris pinus 170 tristis 169

Chuck-will's widow 128

Circus cyaneus 90 hudsonius 90

hudsonicus 90 hyemalis 97

Cistothorus palustris 251
Cistothorus stellaris 251

Clangula albeola 40 clangula americana 39 glaucion 39 hyemalis 41 islandica 40 vulgaris 39

Clivicola riparia 203

Coccoborus caeruleus 196 ludovicianus 195 vespertinus 166

Coccothraustes ludovicianus 195 vespertinus 166

Coccygus americanus 116 erythrophthalmus 117

Coccyzus americanus 116 erythrophthalmus 117

Cock-of-the-Woods 123

Colaptes auratus 126

luteus 126

ayresii 127

cafer 127 collaris 127

collaris 127

hybridus 127

mexicanus 127

Colinus virginianus 78

Columba carolinensis 85 macroura 85 migratoria 84

Collurio borealis 206 ludovicianus excubitoroides 207

Collyrio borealis 206 excubitoroides 207

Colymbus areticus 23 auritus 21, 22 californicus 22 glacialis 22 holboellii 21 nigricollis californicus 22 podiceps 22 septentrionalis 23 torquatus 22

Compsothlypis americana ramalinae 22 usneae 220

Contopus borealis 138

virens 139

Conurus carolinensis 113

Coot, American 62 
Coot, Gray 43
Sea 43
Spectacled 43
Surf 43
$\quad$ White-winged 42
Cormorant, Double-crested 28

Southern 28

Florida 28

Mexican 28

Corporal, Little 103

Corvus americanus 147

brachyrhynchus 147

cacalotl 146

carnivorus 146,147

columbianus 149

corax 146,147

carnivorus 147

principalis 147

sinuatus 146

corone 147

cristatus 144

frugivorus 147

pica 144

sinuatus 146

Corydalina bicolor 198

Corythus enucleator 166

Cotile riparia 203

Coturniculus bairdii 176 henslowii 178

leconteii 179

passerinus 177

perpallidus 178

savannarum bimaculatus

178

passerinus

177

Cotyle riparia 203

serripennis 204

Cowbird 151

Crake, Carolina 59

Crane, Blue 52

Brown 57

Hooping 56

Little Brown 57

Sandhill 57

Northern 57

White 53

Whooping 56, 57

Creeper, Brown 252

Crex galeata 61
Cricket Bird 177

Crossbill, American 167

White-winged 168

Crow, American 147

Carrion 87

Clarke's 149

Crymophilus fulicarius 62

Cryptoglaux acadica 108 tengmalmi richardsonii 108

Cuckoo, Black-billed 117

Yellow-billed 116

Cuculus auratus 126

carolinensis 116

erythrophthalmus 117

Culicivora caerulea 259

Cupidonia cupido 81

Curlew, Eskimo 75

Esquimaux 75

Hudsonian 75

Jack 75

Long-billed 74

Short-billed 75

Curvirostra americana 167

leucoptera 168

Cyanocitta cristata 144

Cyanospiza amoena 197

ciris 197

cyanea 196

Cyanurus cristatus 144

Cygnus americanus 48

bewickii 48

buccinator 48

ferus 48

Cygnus musicus 48

Cypselus pelasgia 132

Dabchick 22

Dacnis protonotaria 213

vermivora 214

Dafila acuta 36

Darter 27

Demiegretta ludoviciana 54

pealii 54

rufa 54

Dendrocygna fulva 47

Dendroica aestiva 222

blackburniae 228

caerulescens 222

canadensis 222 
Dendroica castanea 227

cerulea 225

coronata 223

discolor 232

dominica 229

albilora 229

kirtlandi 231

maculosa 224

palmarum 232

pensylvanica 226

pinus 231

rara 225

striata 227

superciliosa 229

tigrina 221

vigorsii 231

virens 230

Dendronessa sponsa 37

Dichromanassa rufa 54

rufescens 54

Dickcissel 198

Dipper 22, 40

Diver, Arctic 23

Great Northern 22

Dolichonyx bicolor 198

oryzivorus 149

Dough Bird 70, 75

Dove, Carolina 85

Mourning 85

Dowitcher 66

Long-billed 66

Red-bellied 66

Dryobates borealis 121

pubescens medianus 120

villosus 119

audubonii 120

Duck, Black 32

Red-legged 32

Dusky 32

Fish 30, 31

Fool 43

Gray 32

Harlequin 41

Long-tailed 41

Ring-necked 39

Ruddy 43

Scaup 38

Lesser 38

Scoter 42

Spine-tailed 43
Duck, Spoon-billed 35

Summer 37

Surf 43

Black 42

Tree, Fulvous 47

Velvet 42

Wood 37

Dunlin 69

Dytes auritus 21

Eagle, American 100

Bald 100

Black 100

Golden 100

Gray 100

Ring-tailed 100

White-headed 100

Ectopistes macrura 84

migratoria 84

Egret, American 53

Peale's 54

Reddish 54

White, Little 54

Egretta candidissima 54

Elanoides forficatus 88

Elanus dispar $\$ 9$

furcatus 88

glaucus 89

leucurus 89

Emberiza americana 198

amoena 197

bairdii 176

canadensis 184

ciris 197

erythrophthalma 193

graminea 175

grammaca 180

henslowii 178

lapponica 173

leconteii 179

leucophrys 182

melodia 190

nivalis 172

ornata 174

orycivora 149

pallida 18.5

passerina 177

pecoris 151

picta 173

pusilla 186

savannarum 175 
Emberiza shattuckii 185

smithii 173

socialis 184

Empidonax acadicus 140

flaviventris 140

minimus 142

pusillus 141

traillii 141

traillii 141

alnornum 141

virescens 140

Ephialtes asio 109

Eremophila alpestris 142 praticola 143

cornuta 142

Eremetes occidentalis 70 petrificatus 69,70

pusillus 69,70

Erismatura jamaicensis 43 rubida 43

Erythrospiza purpurea 167

Eudocinus albus 49

Euphagus carolinus 162

cyanocephalus 163

Euspiza americana 198

Falco anatum 102

atricapillus 93

borealis 94

buteo 97

buteoides 97

chrysaëtos 100

columbarius 103

communis anatum 102

cooperii 92

cyanus 90

dispar 89

ferrugineus 99

forficatus 88

furcatus 88

fuscus 91

harlani 96

hudsonius 90

hyemalis 97

lagopus 99

lanarius mexicanus 101 polyagrus 101

leucocephalus 100

leverianus 94

lineatus 97
Falco lithofalco columbarius 103

mexicanus 101

mississippiensis 90

niger 99

ossifragus 100

palumbarius 93

peregrinus anatum 102

plumbeus 90

polyagrus 101

richardsonii 103

sancti-johannis 99

sparverius 103

stanleyi 92

temerarius 103

uliginosus 90

velox 91

washingtonii 100

Falcon, Peregrine 102

Prairie 101

Finch, Purple 167, 197

Fish Duck 30, 31

Fish-hawk 104

Flicker, Northern 126

Red-shafted 127

Florida caerulea 54

Flycatcher, Acadian 140

Alder 141

Crested 137

Great Crested 137

Green Crested 140

Least 142

Little 141

Olive-sided 138

Scissor-tailed 135

Swallow-tailed 135

Traill's 141

Yellow-bellied 140

Fly-up-the-creek 55

Fringilla albicollis 183

ambigua 151

americana 198

amoena 197

arborea 184

bachmani 189

bicolor 198

caerulea 196

canadensis 184

cardinalis 194

carduelis 171

candacuta 179 


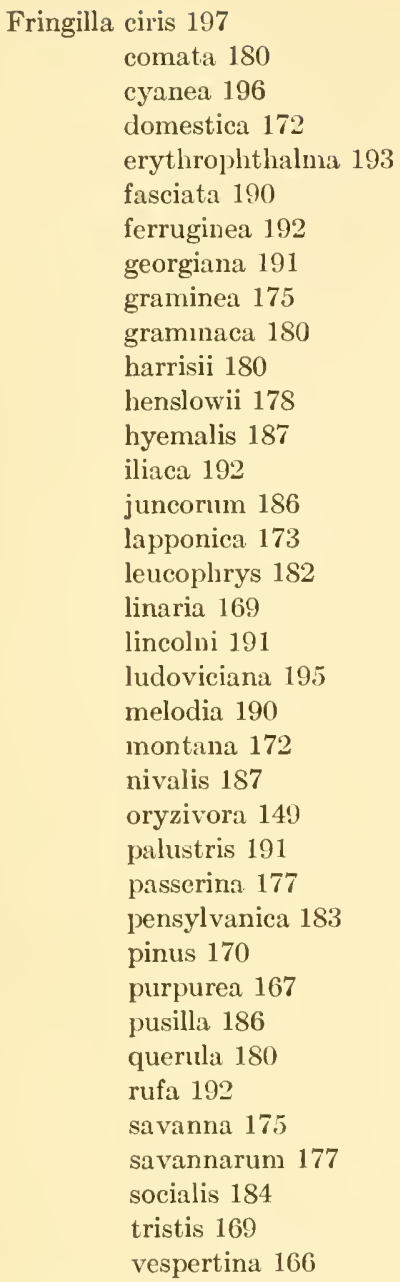

Fulica americana 62

atra 62

martinica 61

Fuligula affinis 38

albeola 40

americana 37,42

clangula 39

collaris 39

ferina 37

fusca 42

histrionica 41

marila 38

mariloides 38
Fuligula minor 38

perspicillata 43

rubida 43

spectabilis 42

vallisneria 37

Fulix affinis 38

collaris 39

marila 38

Gadwall 32

Galeoscoptes carolinensis 245

Gallinago delicata 65 wilsoni 65

Gallinula chloropus 61 galeata 61 porphyrio 61

Gallinule, Florida 61

Purple 61

Gambetta flavipes 72 melanoleuca 71

Garrot 39

Rocky Mountain 40

Garrulus cristatus 144

Garzetta candidissima 54

Gavia arctica 23

imber 22

lumme 23

Geothlypis agilis 236

formosa 235

philadelphia 237

trichas brachidactyla 238

Glaucionetta clangula americana 39 islandica 40

Gnatcatcher, Blue-gray 259

Godwit, Black-tailed 71

Hudsonian 71

Marbled 70

Ring-tailed 71

Golden-eye, American 39

Barrow's 40

Goldfinch, American 169 European 171

Goniaphea caerulea 196 ludoviciana 195

Goosander 30

Goose, Blue 45

Blue-winged 45

Cackling 47

Canada 45

Lesser 46 
Goose, Hutchin's 46

Laugling 45

Snow 44, 45

Greater 44

Lesser 44

White-fronted, American 45

Wild 45

Little 46

Goshawk, American 93

Gourdhead 51

Grackle 163

Blue-headed 163

Bronzed 163

Rusty 162

Gracula ferruginea 162

Graculus dilophus 28

Grassfinch 175

Grayback 66, 67

Great Head 39

Grebe, California 22

Carolina 22

Eared, American 22

Holboell's 21

Horned 21, 22

Pied-billed 22

Red-necked, American 21

Thick-billed 22

Western 21

Grosbeak, Blue 196

Evening 166

Pine 166

Canadian 166

Rose-breasted 195

Grouse, Pinnated 81

Ruffled 79

Grus americanus 56, 57

canadensis 57

fraterculus 57

hoyanus 56

mexicana 57

Guara alba 49

Guiraca caerulea 196

cardinalis 194

ludoviciana 195

Gull, Bonaparte's 25

Common, American 25

Fork-tailed 25

Franklin's 25

Herring 24

American 24
Gull, Ring-billed 25

Rosy, Franklin's 25

Sabine's 25

Sea 24

Habia ludoviciana 195

Haliaëtus washingtonii 100

Haliaeetus leucocephalus 100

Hangnest 161

Harelda glacialis 41

hyemalis 41

Harlequin Duck 41

Harporhynchus rufus 246

Harrier, American 90

Hawk, Black 99

Black-shouldered 89

Blue 92

Broad-winged 98

Cooper's 92

Duck 102

Fish 104

Harlan's 96

Krider's 95

Marsh 90

Mouse 90

Pigeon 103

Red-shouldered 97

Red-tailed 94

Rough-legged, American 99

Sharp-shinned 91

Sparrow, American 103

Squirrel, California 99

Swainson's 97

Swallow-tailed 88

Hedymeles ludovicianus 195

Helinaia bachmanii 215

celata 218

chrysoptera 217

peregrina 219

protonotarius 213

rubricapilla 218

solitaria 216

swainsonii 214

vermivora 214

Helldiver 22

Helmintherus vermivorus 214

Helminthophaga bachmani 215

celata 218

chrysoptera 217

leucobronchialis 216 
Helminthophaga peregrina 219 pinus 216 ruficapilla 218

Helminthophila bachmanii 215 celata 218 chrysoptera 217 leucobronchialis 216 peregrina 219 pinus 216 rubricapilla 218 ruficapilla 218

Helminthotherus vermivorus 214

Helmitherus swainsoni 214 vermivorus 214

Helodromas solitarius 72 Helonaea swainsonii 214

Herodias alba egretta 53

Heron, Fish 52 egretta 53

Great Blue 52

Green 55

Little Blue 54

Little White 54

Louisiana 54

Night, Black-crowned 55 Yellow-crowned 56

Snowy 54

White 53

Hesperiphona vespertina 166

High-holder 126

Himantopus mexicanus 64 nigricollis 64

Hirundo americana 202 bicolor 203 erythrogaster 202 fulva 201 horreorum 202 lunifrons 201 pelasgia 132 purpurea 201 republicana 201 riparia 203 rufa 202 rustica 202 serripennis 204 subis 201 viridis 203

Histrionicus histrionicus 41 minutus 41 torquatus 41
Hummingbird, Ruby-throated 134 Hydranassa tricolor ludoviciana 54 ruficollis 54

Hydrochelidon fissipes 27 lariformis 27 nigra surinamensis 27 plumbea 27

Hylocichla aliciae 261 bicknelli 262 fuscescens 260 salicicola 260

guttata pallasii 263 mustelina 259 unalascae pallasii 263 ustulata swainsonii 262

Hylotomus pileatus 123

Ibis alba 49

Bay 50

Glossy 50

Green 50

guarauna 50

falcinellus 50

Ordii 50

$$
\text { v. Ordii } 50
$$

thalassinus 50

White 49

White-faced Glossy 50

Wood 51

Icteria virens 239 viridis 239

Icterus baltimore 161 galbula 161 icterocephalus 154 pecoris 151 phoeniceus 155 spurius 160 xanthocephalus 154

Ictinia mississippiensis 90 plumbea 90 subcaerulea 90

Indian Pullet 51

Ionornis martinica 61

Iridoprocne bicolor 203

Jaeger, Parasitic 24 Richardson's 24

Jay Bird 144

Joree 193

Junco 187 
Junco hiemalis 187

hyemalis 187

connectens 188

shufeldti 188

montanus 189

Shufeldt's 188

Slate-colored 187

Kestrel, American 103

Killdeer 76

Kingbird 13.5

Arkansas 136

King Eider 42

Kingfisher, Belted 118

Kinglet, Golden-crowned 257

Ruby-crowned 258

Kite, Fork-tailed 88

Mississippi 90

Swallow-tailed 88

White-tailed 89

Kittiwake 24

Knot 67

Lanius borealis 206

excubitor 206

ludovicianus 207

migrans 207

tyrannus 135

Lanivireo flavifrons 210

solitarius 210

Lanner 101

Lark, Horned 142, 143

Hoyt's 143

Prairie 143

Prairie 143

Shore 142

Snow 142

Larus argentatus 24

smithsonianus 24

bonapartei 25

delawarensis 25

franklinii 25

philadelphia 25

sabinii 25

tridactylus 24

zonorhynchus 25

Lawyer 64

Lead-back 69

Lestris richardsonii 24

Limosa fedoa 70
Limosa foeda 70

haemastica 71

hudsonica 71

scolopacea 66

Linaria minor 169

pinus 170

Lobipes hyperboreus 62

lobatus 62

Log-cock 123

Long-beak, Greater 66

Long-bill 65

Long-shanks 64

Longspur, Chestnut-collared 174

Lapland 173

McCown's 174

Smith's 173

Look-up 51

Loon 22

Arctic 23

Black-throated 23

Red-throated 23

Lophodytes cucullatus 31

Lophophanes bicolor 255

Loxia americana 167

caerulea 196

cardinalis 194

curvirostra 167

americana 167

minor 167

enucleator 166

leucoptera 168

ludoviciana 195

rosea 195

Macrorhamphus griseus 66

scolopaceus 66 scolopaceus 66

Magpie, American 144

Mallard 31

Black 32

Mareca americana 33

penelope 33

Marlin 70

Black-tailed 71

Ring-tailed 71

Marsh Hen 58

Martin 201

Purple 201

Sand 203

Maybird 67 
Meadowlark 156

Southern 160

Western 157

Megascops asio 109

Melanerpes carolinus 126 erythrocephalus 124

Melanetta velvetina 42

Meleagris gallopavo 83

$$
\begin{aligned}
& \text { fera } 83 \\
& \text { silvestris } 83
\end{aligned}
$$

Mellisuga colubris 134

Melospiza cinerea melodia 190

fasciata 190

georgiana 191

lineolnii 191

meloda 190

melodia 190

palustris 191

Merganser americanus 30

serrator 30

Merganser, American 30

Hooded 31

Red-breasted 30

Mergus americanus 30

cucullatus 31

merganser 30

serrator 30

Merlin, American 103

Richardson's 103

Merula migratoria 264

Micropalama himantopus 66

Microptera americana 64

Milvulus forficatus 135

Milvus furcatus 88

leucurus 89

Mimus carolinensis $\mathbf{2 4 5}$

felivox 245

polyglottus 244

Mniotilta borealis 212

varia 212

borealis 212

Mocker 244

Mockingbird 244

Molothrus ater 151

Moorhen 61

pecoris 151

Mosquito hawk 130

Motacilla aestiva 222

chrysoptera 217

citrea 213
Motacilla maculosa 224

tigrina 221

Mudhen 61, 62

Mud-peep 69

Muscicapa atra 137

bonapartei 241

caerulea 259

canadensis 241

cantatrix 211

carolinensis 245

crinita 137

cucullata 240

forficata 135

fusca 137

gilva 209

melodia 209

noveboracensis 211

nunciola 137

olivacea 208

phocbe 137

pusilla 240

querula 139, 140

rapax 139

ruticilla 242

saya 138

selbii 240

solitaria 210

sylvicola 210

traillii 141

tyrannus 135

verticalis 136

virens 139

Muscivora forficata 135

Myiarchus crinitus 137

Myiodioctes bonapartei 241

canadensis 241

formosus 235

mitratus 240

pusillus 240

pileolatus 241

wilsonii 240

Nauclerus forficatus 88

furcatus 88

Neocorys spraguei 243

Nettion carolinensis 34

Nighthawk 130

Sennetti 131

Western 131

Night Raven 55 
Niphea hyemalis 187

Nisus fuscus 91 pensylvanieus 91

Nonpareil 197

Nucifraga columbiana 149

Numenius borealis 57 hudsonicus 75 intermedius 75 longirostris 74

Nutcracker, Clarke's 149

Nuthatch, Brown-headed 254

Canada 254

Carolina 253

Red-bellied 254

Red-breasted 254

White-bellied 253

White-breasted 253

Nuttallornis borealis 138

Nyctale acadica 108

albifrons 108

frontalis 108

kirtlandi 108

richardsoni 108

tengmalmi richardsoni 108

Nyctanassa violacea 56

Nyctea nivea 112

nyctea 112

scandiaca v. aretica 112

Nycterodius violaceus 56

Nyctiardea gardeni 55 grisea naevia 55 violacea 56

Nycticorax nycticorax naevius 55 violaceus 56

Oidemia americana 42

$$
\begin{aligned}
& \text { bimaculata } 42 \\
& \text { deglandi } 42 \\
& \text { fusca } 42 \\
& \quad \text { velvetina } 42 \\
& \text { perspicillata } 43 \\
& \text { velvetina } 42
\end{aligned}
$$

Olbiorchilus hiemalis 250

Old-squaw 41

Old-wife 41

Olor americanus 48 buccinator 48 columbianus 48

Oporornis agilis 236 formosus 235
Oriole, Baltimore 161

Orehard 160

Oriolus baltimore 161

mutatus 160

spurius 160

Orpleus carolinensis 245

$$
\text { rufus } 246
$$

Ortolan 59

Ortygometra carolina 59 noveboracensis 60

Ortyx virginianus 78

Osprey, Ameriean 104

Otocoris alpestris 142 hoyti 143 praticola 143

Otus americanus 105 brachyotus 106 vulgaris $\mathrm{v}$. wilsonianus 105 wilsonianus 105

Ovenbird 233

Owl, Acadian 108

Barn, American 105

Barred 107

Cat 106

Great Gray 107

Hawk, American 113

Hoot 107

Horned, Great 110

Western 112

Kirtland's 108

Long-eared, American 105

Marsh 106

Monkey-faced 105

Mottled 109

Prairie 106

Richardson's 108

Saw-whet 108

Screech 109

Short-eared 106

Snowy 112

Sparrow, American 108

Ox-bird 69

Ox-eye 76

Oxyechus vociferus 76

Pandion carolinensis 104

haliaetus 104

haliaëtus carolinensis 10.4

Parakeet 113

Paroquet, Carolina 113 
Parrot, Orange-headed 113

Partridge 78, 79

Parula americana 220

Parus atricapillus 255, 256 carolinensis 256

bicolor 255 septentrionalis 256

carolinensis 256

palustris 255

agilis 257

septentrionalis 256

Passer domesticus 172 montanus 172

Passerculus alaudinus 176

bairdi 176

sandwich. alaudinus $\mathbf{1 7 6}$ savanna 175

savanna 175 alaudinus 176

Passerella iliaca 192

Passerina amoena 197 ciris 197 cyanea 196 nivalis 172

Peabody bird 183

Peep 69

Peet-weet 74

Pelecanus americanus 29 dilophus 28 erythrorhynchus 29 onocrotalus 29 trachyrhynchus 29

Pelican, White, American 29

Pelidna alpina sakhalina 69 pacifica 69

Pelionetta perspicillata 43 trowbridgii 43

Penelope mexicana 47

Penthestes atricapillus 255 septentrionalis 256

carolinensis 256

Perdix virginiana 78

Perisoglossa tigrina 221

Petrochelidon lunifrons 201

Peucea aestivalis 189 bachmanii 189 illinoiensis 189

bachmanii 189

illinoiensis 189
Peucea lincolnii 191

Phalacrocorax dilophus 28

floridanus 28

floridanus 28

mexicanus 28

Phalaenoptilus nuttallii 129

nitidus 129

Phalarope, Gray 62

Northern 62

Red 62

Red-necked 62

Wilson's 63

Phalaropus fulicarius 62

hyperboreus 62

lobatus, 62,63

tricolor 63

wilsoni 63

Phasianus colchicus 82

torquatus 82

Pheasant 79

English 82

Ring-necked 82

Philohela minor 64

Phoebe 137

$$
\text { Say's } 138
$$

Pica caudata hudsonica 144

hudsonica 144

melanoleuca 144

pica hudsonica 144

Picicorvus columbianus 149

Picus audubonii 120

auratus 126

borealis 121

carolinus 126

erythrocephalus 124

mexicanus 127

pileatus 123

principalis 119

pubescens 120

querulus 121

varius 122

villosus 119

Pigeon, Passenger 84

Wild 84

Pinicola canadensis 166

enucleator 166

canadensis 166

leucura 166

Pintail 36

Pipilo erythrophthalmus 193 
Pipit, American 243

Sprague's 243

Pipra polyglotta 239

Piranga erythromelas 199

rubra 200

Pitylus cardinalis 194

Plectrophanes lapponicus 173 mecownii 174 melanomus 174 nivalis 172 ornatus 174 pictus 173

Plectrophenax nivalis 172

Plegadis autumnalis 50 falcinellus 50 guarauna 50

Plotus anhinga 27 melanogaster 27

Plover, Black bellied 76

Blue 67

Field 73,76

Golden, American 76

Grass 73

Green 76

Killdeer 76

Piping, Belted 77

Ring 77

Semipalmated 77

Ring 77

Upland 73

Pochard 37

Podiceps auritus 22

californicus 22

carolinensis 22

cornutus 21

cristatus 21

griseigena holboelli 21

holboellii 21

occidentalis 21

rubricollis 21

Podilymbus podiceps 22

Polioptila caerulea 259

Poocetes gramineus 175

Pooecetes gramineus 175

Poor-will 129

frosted 129

Pope 197

Porphyrio martinica 61

Porzana carolina 59 jamaicensis 60
Porzana noveboracensis 60

Prairie Chicken 81

Hen 81

Lesser 82

Preacher 208

Progne purpurea 201 subis 201

Protonotaria citrea 213

Psittacus carolinensis 113

Pyranga aestiva 200 erythromelas 199 mississippiensis 200 rubra 199

Pyrgita montana 172

Pyrrhula enucleator 166

Qua-bird 55

Quail 78

Quawk 55

Querquedula carolinensis 34 cyanoptera 35 discors 34

Quiscalus aeneus 163 breweri 163 ferrugineus 162 purpureus 163 aeneus 163 quiscula aeneus 163 versicolor 163

Rail, Black 60

\section{Little 60}

Common 59

King 58

Red-breasted, Great 58

Little 59

Virginia 59

Yellow 60

Raincrow 116, 117

Rallus carolinus 59

elegans 58

jamaicensis 60

noveboracensis 60

virginianus 59

Raven, American 146, 147

Mexican 146

Northern 147

Recurvirostra americana 63

himantopus 64

Red-bark 69 
Redbiret 194

Sunmer 200

Red-breast 69, 195

Robin 264

Redhead :37

Redpoll 169

Ycllow 2:32

Redstart, American 242

Red-tail, Black 96

Western 96

White-bellied 95

Red-wing, Northern 156 Thick-billed 156

Reedbird 149

Regulus calendula 258 cristatus 257

reguloides 257

satrapa 257

tricolor 257

Rhinogryphus aura 86

Rhyacophilus solitarius 72

Rhynchophanes mecownii 174

Ricebird 149

Ring-bill 39

Ring-neck 39, 77

Riparia riparia 203

Rissa tridactyla 24

Robin, American 264

Rosebreast 195

Rough-leg, Ferruginous 99

Rusticola minor 64

Salad-bird 169

Sand-lark 74

Sand-peep 69

Sanderling 70

Sandpiper, Baird's 68

Bartramian 7:3

Black-bellied 69

Bonaparte's 68

Buff-breasted 73

Common 74

Least 69

Pectoral 67

Purple 67

Red-backed 6?

Red-breasted 67

Semipalmated 69

Solitary 7:2

Spotted 74
Sandpiper, Stilt 66

Western 70

White-rumped 68

Sapsucker, Yellow-bellied 122

Sawbill 31

Sayornis fuscus 137

phoebe 137

saya 138

Scolecophagus carolinus 162

cyanocephalus 163

ferrugineus 162

Scolopax alba 49

borealis 75

delicata 65

douglasii 65

ferloa 70

flavipes 72

gallinago 65

grisea 66

guarauna 50

haemastica 71

melanoleuca 71

minor 64

noveboracensis 66

semipalmata 72

vociferus 71

Scops asio 109

Scoter, American 42

Black 42

Surf 43

Velvet 42

White-winged 42

Scotiaptex cinereum 107 nebulosa 107

Sea Coot 42

Sea Swallow, Common 26

Seiurus aurocapillus 233

ludovicianus 235

motacilla 235

naevius 233

noveboracensis 233

notabilis 233

Setophaga canadensis 241

mitrata 240

ruticilla 242

wilsonii 65,240

Sheldrake, American 30

Buff-breasted 30

Hooded 31

Red-breasted 30 
Shoveller 35

Shrike, Loggerhead, Northern 207

Migrant 207

Northern 206

Shytepoke 55

Sialia sialis 265 wilsonii 265

Sickle-bill 74

Siskin, Pine 170

Sitta canadensis 254 carolinensis 253

pusilla 254

varia 254

Siurus aurocapillus 233 motacilla 235 nacvius 233

Skunkhead 43

Skylark, Missouri 243

Snakebird 27

Snipe, American 65

Grass 67

Gray 66

Jack 65,67

Red-bellied 66

Red-brested 66

Robin 67

Rock 67

Stone 71

White 64

Wilson's 65

Winter 67

Snowbird 172, 187

Snowflake 172

Somateria spectabilis 42

Sora 59

South-southerly 41

Sparrow, Bachman's 189

Baird's 176

Chipping 184

Clay-colored 18.5

Field 186

Western 187

Fox 192

Grasshopper 177

Western 178

Ground 175

Harris's 180

Henslow's 178

Hooded 180

House, English 17:2
Sparrow, Lark 180

Leconte's 179

Lincoln's 191

Nelson's 179

Oakwood 189

Savanna 175

Western 176

Song 190

Swamp 191

Tree, Canada 181

European 172

Vesper 175

White-crowned 182

White-throated 183

Spatula clypeata 35

Speckle-belly 45

Sphyrapicus varius 122

Spinus pinus 170 tristis 169

Spiza americana 198

amoena 197

ciris 197

cyanea 196

Spizella agrestis 186

arenucea 187

domestica 184

montana 184

monticola 184

pallida 185

pusilla 186

arenacea 187

socialis 184

Spoonbill 35

Sprig 36

Sprigtail 36

Squatarola helvetica 76

Squawk 55 squatarola 76

Stake Driver 51

Steganopus tricolor 6.3 wilsoni 63

Stelgidopterix serripennis 204

Stercorarius parasiticus 24

Sterna antillarum 27

argentea 27

caspia 26

fissipes 27

fluviatilis 26

forsteri 26

frenata 27 
Sterna havellii 26

hirundo 26

minuta 27

nigra 27

superciliaris 27

tschegrava 26

wilsonii 26

Stilt 64

Stint 69

Black-necked 64

Strepsilas interpres 78

Strix acadica 108

accipitrinus 106

americana 105

asio 109

brachyotus 106

cinerea 107

flammea 105

americana 105

funerea 113

pratincola 105

hudsonica 113

naevia 109

nebulosa 107

nyctea 112

otus 105

passerina 108

pratincola 105

tengmalmi 108

virginiana 110

Struthus hyemalis 187

Sturnella ludoviciana 156, 157

magna 156

argatula 160

neglecta 157

neglecta 157

Sturnus ludovicianus 156

predatorius 155

Surnia hudsonica 113

naevia 109

nyctea 112

ulula caparoch 113

hudsonica 113

Swallow, Bank 203

Barn 202

Chimney 132

Cliff 201

Eave 201

Rough-winged 204

Tree 203
Swallow, White-bellied 203

Wood 203

Swan, American 48

Trumpeter 48

Whistling 48

Swift, Chimney 132

Sylvania bonapartei 241

canadensis 241

formosa 235

mitrata 240

pusilla 240

pileolata 241

Sylvia aestiva 222

agilis 236

americana 220

autumnalis 227

azurea 225

bachmani 215

blackburniae 228

caerulescens 222

calendula 258

canadensis 222

castanea 227

celata 218

cerulea 225

childrenii 222

chrysoptera 217

citrinella 222

coronata 223

discolor 232

domestica 248

formosa 235

icterocephala 226

leucoptera 222

maculosa 224

magnolia 224

maritima 221

minuta 232

mitrata 240

palmarum 232

pardalina 241

parus 228

pensilis 229

pensylvanica 226

peregrina 219

philadelphia 237

pinus 231

protonotarius 213

pusilla 222

rara 225 
Sylvia rathbonia 222

regulus 257

rubricapilla 218

ruficapilla 218

sialis 265

solitaria 216

striata 227

swainsonii 214

tigrina 221

trichas 238

trochilus 2:2

troglodytes 250

varia 212

vermivora 214

vigorsii 231

virens 230

wilsonii 240

Sylvicola aestiva 222

agilis 236

americana 220

auricollis 213

blackburniae 228

caerulea 225

canadensis 222

castanea 227

coerulea 225

coronata 223

discolor 232

formosa 235

icterocephala 226

kirtlandi 231

maculosa 224

maritima 221

missouriensis 219

palmarum 232

parus 228

pensilis 229

petechia 232

pinus 231

striata 227

varia 212

virens 230

Symphemia semipalmata 72

inornata 72

Syrnium cinereum 107

lapponicum v. cinereum 107

nebulosum 107

variuns 107

Tachycineta bicolor 203
Tanager, Scarlet 199

Summer 200

Tanagra aestiva 200

cyanea 196

rubra 199

Tantalus albus 49

falcinellus 50

guarauna 50

loculator 51

Tattler, Bartram's 73

Semipalmated 72

Wood 72

Teacher 233

Teal, Blue-winged 34

Cinnamon 35

Green-winged 34

Red-breasted 35

Teeter-tail 74

Tell-tale 71

Lesser 72

Telnnatodytes palustris 251

iliacus 251

Teru, Black 27

Caspian 26

Common 26

Forster's 26

Havell's 26

Least 27

Short-tailed 27

Wilson's 26

Tetrao cupido 81

umbellus 79

virginianus 78

Thistle-bird 169

Thrasher, Brown 246

Thrush, Alice's 261

Bicknell's 262

Brown 246

Golden-crowned 233

Gray-cheeked 261

Hermit 263

Olive-backed 262

Swainson's 262

Tawny 260

Water 233

Willow 260

Wilson's 260

Wood 259

Thryomanes bewickii 248

Thryothorus bewickii 248 
Thryothorus ludovicianus 247

Thunder Pump 51

'Tinnunculus sparverius 103

Tip-up 72, 74

Tit, Crested 255

Tufted 255

Titlark 243

Titmouse, Tufted 255

Totanus bartramius 73

chloropygius 72

flavipes 72

macularius 74

melanoleucus 71

semipalmatus 72

solitarius 72

vociferus 71

Towhee 193

Toxostoma rufum 246

Trichas agilis 236

formosa 235

marylandica 238

personatus 238

philadelphica 237

Tringa alpina pacifica 69

arenaria 70

auduboni 66

bairdii 68

bartramia 73

bonapartei 68

canutus 67

cinclus 69

cinerea 67

douglasii 66

fulicaria 62

fuscicollis 68

hiaticula 77

himantopus 66

hyperborea 62

interpres 78

islandica 67

lobata 62

longicauda 73

macularia 74

maculata 67

maritima 67

minutilla 69

pectoralis 67

pusilla 69

rufa 67

rufescens 73
Tringa semipalmata 69

shinzii 68

solitaria 72

squatarola 76

subruficollis 73

wilsonii 69

Tringoides macularius 74

Trochilus colubris 134

Troglodytes aëdon 248

aztecus 248

americanus 248

bewickii 248

brevirostris 251

domesticus 248

europeus 250

fulvus 248

hiemalis 250

ludovicianus 247

palustris 251

parvulus hyemalis 250

Tryngites rufescens 73

subruficollis 73

Turdus aliciae 261

bicknelli 262

aonalaschkae pallasii 263

aquaticus 233

aurocapillus 233

carolinus 162

fuscescens 260

salicicolus 260

lividus 245

ludovicianus 235

melodus 259

migratorius 264

minor 263

mustelinus 259

noveboracensis 233

pallasii 263

polyglottus 244

rufus 246

solitarius 263

swainsonii 262

aliciae 261

ustulatus aliciae 261

swainsonii 262

wilsonii 260

Turkey, Colorado 51

Wild 83

Turnstone, Ruddy 78

Tympanuchus americanus 81 
Tympanuehus pallidicinctus 82

Tyrannula flaviventris 140

minima 142

nunciola 137

virens 139

Tyrannus aeadicus 140

borealis 138

carolinensis 135

crinitus 137

forficatus 135

fuscus 137

trailli 141

tyrannus 135

verticalis 136

Ulula acadica $10 S$

brachyotus 106

flammea 105

nebulosa 107

otus 105

virginiana 110

Urinator areticus 23

immer 22

lumme 23

Veery 260

Vermivora celata 218

chrysoptera 217

penusylvanica 214

peregrina 219

protonotarius 213

rubricapilla 218

solitaria 216

Vireo bellii 211

Bell's 211

Blue-headed 210

Brotherlylove 208

flavifrons 210

gilvus 209

noveboracensis 211

olivaceus 208

Philadelphia 208

philadelphicus 208

Red-eyed 208

solitarirus 210

Solitary 210

spluagnosa 222

Warbling 209

White-eyed 211

Yellow-throated 210
Vireosylva gilva 209

olivacea 208

philadelphica 208

Vireosylvia gilva 209

olivacea 208

philadelphica 208

Vultur atratus 87

aura 86

iota 87

Vulture, Black 87

Red-headed 86

Turkey 86

Walloon 22

Warbler, Bachman's 215

Bay-breasted 227

Black and White 212

Black and Yellow 224

Blackburnian 228

Black-capped 240

Black-poll 227

Black-throated Blue 222

Green 230

Blue 225

Blue-eyed 222

Blue-winged 216

Brewster's 216

Canada 241

Fly-catching 241

Cape May 221

Cerulean 225

Chestnut-sided 226

Connecticut 236

Creeping, Black and White 212

Golden-winged 217

Hooded 240

Kentucky 235

Kirtland's 231

Magnolia 224

Mourning 237

Myrtle 223

Nashville 218

Orange-crowned 218

Palm 232

Parula 220

Northern 220

Western 220

Pileolated 241

Pine 231

Pine-crceping 231 
Warbler, Prairie 232

Prothonotary 213

Swainson's 214

Swamp, Golden 213

Worm-enting 214

Sycamore 229

Tennessee 219

Wilson's 240

Worm-eating 214

Yellow 222

Blue-winged 216

Yellow-crowned 226

Yellow-rumped 223

Warrior, Black 96

Waterhen 61

Water Thrush 233

Grinnell's 233

Large-billed 235

Louisiana 235

Small-billed 233

Water Turkey 27, 51

Water-witch 22

Wax-wing, Bohemian 205

Cedar 205

Whip-poor-will 128

Nuttall's 129

Whistler 39

Whistle-wing 39

White-back 37

White-belly 203

Widgeon 33

American 33

Willet 72

Western 72

Wilsonia canadensis 241

mitrata 240

pusilla 240

pileolata 241

Woodcock, American 64

Black 123

Woodpecker, Downy 120

Golden-winged 126

Hairy 119

Southern 120

Ivory-billed 119

Pigeon 126
Woodpecker, Pileated, Northern 123

Southern 123

Red-bellied 126

Red-cockated 121

Red-headed 124

White-billed 119

Yellow-bellied 122

Yellow-shafted 126

Yellow-winged 126

Wood Pewee 139

Wren, Bewick's 248

Carolina 247

House 248

Long-tailed 248

Western 248

Marsh, Prairie 251

Short-billed 251

Winter 250

Xanthocephalus icterocephalus 154 xanthocephalus 154

Xema sabinii 25

Yellow-back, Blue 220

Yellowbird 222

Yellow-hammer 126

Yellow-legs 72

Greater 71

Yellow-rump 223

Yellowshanks, Greater 71

Lesser 72

Yellow-throat, Maryland 238

Nortbern 238

Yphantes baltimore 161

Zamelodia ludoviciana 195

Zenaidura carolinensis 85

macroura 85

Zonotrichia albicollis 183

graminea 175

iliaca 192

leucophrys 182

lincolni 191

palustris 191

pensylvanica 183

querula 180

Issued November 16, 1907. 
. 


